UNIVERSIDADE DE BRASÍLIA

FACULDADE DE TECNOLOGIA

DEPARTAMENTO DE ENGENHARIA CIVIL E AMBIENTAL

PROGRAMA DE PÓS-GRADUAÇÃO EM TRANSPORTES

\begin{abstract}
AVALIAÇÃO DA PERCEPÇÃO DE QUALIDADE DA PRESTAÇÃO DO SERVIÇO DE TRANSPORTE INDIVIDUAL DE PASSAGEIROS DO DISTRITO FEDERAL: TÁXI E UBER
\end{abstract}

FERNANDO MEISTER VIEIRA DE FARIAS

ORIENTADOR: PAULO CESAR MARQUES DA SILVA COORIENTADOR: EVALDO CESAR CAVALCANTE RODRIGUES

DISSERTAÇÃO DE MESTRADO EM TRANSPORTES

PUBLICAÇÃO: T.DM-014/2016

BRASÍLIA / DF: JULHO/2016 


\section{UNIVERSIIDADE DE BRASÍILIIA}

FACULDADE DE TECNOLOGIIA

DEPARTAMIENTO DE ENGENHARIA CIVIL E AMIBIIENTAL PROGIRAMA IDE PÓS-GRADUAÇÃO EMITRANSPORTES

\section{AVALIAÇÃO DA PERCEPÇÃO DE QUALIIDADE DA PRESTAÇÃO DO SERVICCO DE TRANSPORTE INDIVIIDUAL DE PASSAGEIIROS DO DISTIRITO FEIDERAL: TÁXI E UBER}

\section{FERNANDO MEISTER VIEIIRA IDE FARIAS}

DISSERTAÇ̃̃O DE MESTRADO SUBMIETIDA AO PROGRAMA DE PÓSGRADUAÇÃO EMI TRANSPORTES DO DEPARTAMENTO DE ENGENHARIA CIVIL E AMIBIENTAL DA FACULDADE DE TECNOLOGIA DA UNIVERSIIDADE DE bRASílLIA COMO PARTE DOS REQUISITOS NECESSÁRIOS PARA OBTENÇÃO DO GRAU DE MESTRE EM TRANSPORTES.

\section{APROVADA POR:}

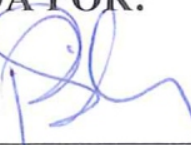

PAULO CESAR MARQUES DA SILVA, Doutor, (ENC-UnB)

(Orientador)

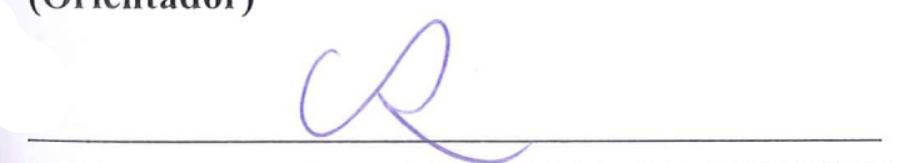

EVALDO CESAR CAVALCANTE RODRIGUES, Doutor, (ADM-UnB)

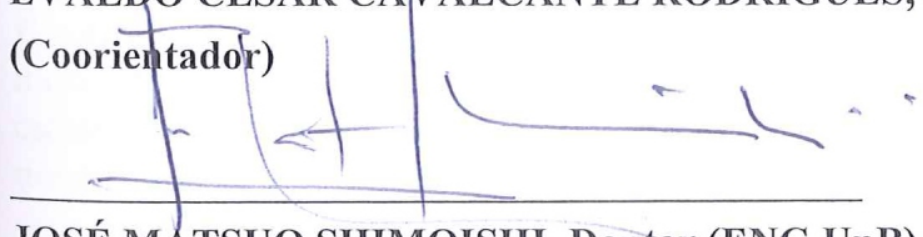

JOSÉ MATSUO SHIIMOISHI, Doutor (ENC-UnB)

(Examinador Interno)

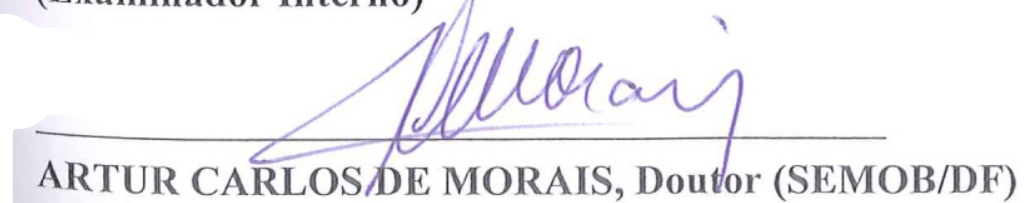

(Examinador Externo) 


\section{FICHA CATALOGRÁFICA}

\section{FARIAS, FERNANDO MEISTER VIEIRA DE}

Avaliação da percepção de qualidade da prestação do serviço de transporte individual de passageiros do Distrito Federal: táxi e Uber [Distrito Federal] 2016.

xiii, 129p., 210 x 297 mm (ENC/FT/UnB, Mestre, Transportes, 2016). Dissertação de Mestrado - Universidade de Brasília. Faculdade de Tecnologia.

Departamento de Engenharia Civil e Ambiental.

1. Transporte Individual

3. Uber

5. Análise Multicritério

I. ENC/FT/UnB
2. Táxi

4. Usabilidade

6. Construtivista

II. Título (série)

\section{REFERÊNCIA BIBLIOGRÁFICA}

FARIAS, F. M. V. (2016) Avaliação da Percepção de Qualidade da Prestação de Serviço de Transporte Individual de Passageiros do Distrito Federal: Táxi e Uber. Dissertação de Mestrado Transportes, Publicação T.DM-014/2016, julho, 2016, Departamento de Engenharia Civil e Ambiental, Universidade de Brasília, Brasília, DF, 129p.

\section{CESSÃO DE DIREITOS}

Autor: Fernando Meister Vieira de Farias

Título: Avaliação da Percepção de Qualidade da Prestação de Serviço de Transporte Individual de Passageiros do Distrito Federal: Táxi e Uber.

Grau: Mestre

Ano: 2016

É concedida à Universidade de Brasília permissão para reproduzir cópias desta dissertação de mestrado e para emprestar ou vender tais cópias somente para propósitos acadêmicos e científicos. O autor reserva outros direitos de publicação e nenhuma parte dessa dissertação de mestrado pode ser reproduzida sem autorização por escrito do autor.

Fernando Meister Vieira de Farias

SAIN Estação Rodoferroviária, Sobreloja - Ala Sul (DFTRANS)

70.631-900 Brasília - DF - Brasil

fernando_meister@hotmail.com 
"Liberdade é o espaço que a felicidade precisa"

Fernando Sabino 


\section{AGRADECIMENTOS}

Agradeço à minha mãe, por estar sempre presente em minha vida e pela dedicação e apoio aos estudos que sempre me oportunizou.

Ao meu pai, meus irmãos e primos, que me apoiaram e torceram por mim.

À Anna Beatriz, que me apoiou em todos os momentos durante a pesquisa, pelas longas conversas e pela paciência.

Ao meu orientador, Prof. Paulo Cesar, que acreditou na minha capacidade desde o início, me apoiou com a mudança do tema da pesquisa e dedicou seu valioso tempo para me orientar.

Ao meu coorientador, Prof. Evaldo que, sempre prestativo, teve papel fundamental para o aprendizado da ferramenta de pesquisa e me deu novo fôlego para trabalhar. Agradeço à sua dedicação, atenção e disponibilidade.

A todos os demais professores do Programa de Pós-Graduação em Transportes, em especial à professora Michelle pelas valiosas conversas e ao professor José Fortes que, mesmo à distância, se dedicou em me ajudar nas disciplinas de Seminário 1 e 2.

Não posso esquecer também da Lucinete e da Camila, que sempre estiveram disponíveis para me orientar quanto às questões burocráticas do curso.

Aline e Zuleide, que sempre acreditaram em mim, me incentivaram, me orientaram e me motivaram durante todas as etapas do curso.

A todos os demais colegas do PPGT que tive oportunidade de conhecer e compartilhar conhecimento e amizade.

Aos meus colegas do DFTRANS e da SUFISA, pela parceria e apoio.

A todos que colaboraram em responderem os questionários da minha pesquisa e os demais que, de alguma forma, me apoiaram e torceram por mim, a minha GRATIDÃO! 


\section{RESUMO}

Apesar do seu público-alvo diferenciado, o serviço de transporte individual de passageiros contribui para a melhoria da mobilidade, na medida em que diminui a quantidade de carros particulares nas cidades. Para incentivar o uso desse modo de transporte, é importante o monitoramento da sua qualidade, de forma a melhorar a compreensão da percepção de qualidade do serviço pelo passageiro. O Método Multicritério de Apoio à Decisão Construtivista (MCDA-C) permite ao gestor avaliar a qualidade dos serviços prestados a partir da percepção do usuário e de acordo com os critérios que julgar pertinentes, possibilitando assim a obtenção de um feedback acerca de suas expectativas, bem como a identificação dos itens que demandam menor esforço para a melhoria do serviço. Nesse sentido, a qualidade está diretamente relacionada ao termo "usabilidade", que se constitui no instrumento que permite a adequação do ambiente do sistema de transporte a quem o utiliza. $\mathrm{O}$ trabalho foi dividido, basicamente, em quatro etapas: a primeira foi a construção do modelo de avaliação; a segunda foi a aplicação dos questionários; em terceiro lugar, foi feita a tabulação dos dados e inserção no software e; por último, foram analisados os resultados de acordo com o referencial teórico. Os resultados encontrados na aplicação do modelo demonstraram que o serviço Uber proporciona melhor percepção de qualidade do que o tradicional serviço de táxi, ao passo em que a diferença de pontuação entre os dois serviços foi bastante significativa. O serviço de táxi apresentou, como média, o nível próximo ao neutro (ou indiferente), e o Uber obteve avaliação próxima ao maior desempenho possível (excelente). 


\begin{abstract}
Despite its distinctive target group, the service of individual passenger transport contributes to improving mobility, in so far as it decreases the amount of private cars in cities. To encourage the use of such transport mode, monitoring of its quality is important in order to improve the understanding of the passengers' perception regarding the service quality. The Multicriteria Decision Aid - Constructivist (MCDA-C) method allows the manager to evaluate the service quality from the users' perception and according to criteria considered most appropriate, in order to obtain a feedback about their expectations, as well as the identification of which items require less effort to the improvement the service. In this sense, the quality is directly related to the term "usability", recognized as the constitutive instrument that allows the suitability of the transport system environment for those who use it. This study is divided basically in four chapters: the first aims to explain the construction of the assessment model; the second performs and describes the application forms; the third is about data - their tabulation and insertion into the software were made in order to provide the scenario regarding cab and Uber perceptions; and finally, the last part presents the results according to the theoretical framework established. The results of the application of the model showed that the Uber service provides better perceived quality than the traditional taxi service, while in the score difference between the two services was significant. The mean level presented by the taxi service was close to neutral (or indifferent), and Uber got an evaluation close to the highest possible performance (excellent).
\end{abstract}




\section{SUMÁRIO}

1. INTRODUÇÃO 1

1.1 APRESENTAÇÃO 2

1.2. PROBLEMA 3

1.3. OBJETIVOS 4

1.4. JUSTIFICATIVA 5

1.5 METODOLOGIA DA PESQUISA 9

1.5.1 DETALHAMENTO DA METODOLOGIA APLICADA 11

1.5.2 CLASSIFICAÇÃO DA PESQUISA

1.5.3 POPULAÇÃO E AMOSTRA 14

1.5.4 PLANO DE COLETA DE DADOS 15

1.5.5 PLANO DE ANÁLISE DE DADOS 16

1.6 ESTRUTURA DA DISERTAÇÃO 17

2. HISTÓRICO E CONTEXTUALIZAÇÃO DO TRANSPORTE INDIVIDUAL DE PASSAGEIROS

2.1 A RELAÇÃO DO PÚBLICO E DO PRIVADO NO TRANSPORTE INDIVIDUAL 20

2.2 TRANSPORTE 21

2.3 FROTA DE VEÍCULOS NO DISTRITO FEDERAL 23

2.4 O SERVIÇO DE TÁXI NO DISTRITO FEDERAL 25

2.4.1 A SEGURANÇA JURÍDICA PROPORCIONADA PELA SUBSTITUIÇÃO DAS PERMISSÕES POR AUTORIZAÇÕES NO DISTRITO FEDERAL 29

2.5 ORIGEM DO SERVIÇO PRESTADO PELA UBER 31

2.5.1 O SERVIÇO UBER PRESTADO NO DISTRITO FEDERAL E SUAS IMPLICAÇÕES

2.6 DIFERENÇAS TARIFÁRIAS DOS SERVIÇOS DE TÁXI E UBER 34

2.7 SISTEMA DE AVALIAÇÃO ATUAL DOS SERVIÇOS DE TÁXI E UBER 35

2.7.1 AVALIAÇÃO DO SERVIÇO DE TÁXI 35

2.7.2 AVALIAÇÃO DO SERVIÇO UBER 36

3. QUALIDADE NO SERVIÇO DE TRANSPORTE 37 
3.1 PRÁTICAS DE QUALIDADE IDENTIFICADAS SOBRE SERVIÇO DE TÁXI E UBER

3.2 MEDIDAS DE AVALIAÇÃO DE QUALIDADE

3.3 USABILIDADE NO TRANSPORTE

3.4 MÉTODOS DE AVALIAÇÃO DE QUALIDADE EM TRANSPORTE E APLICAÇÕES

4. MODELO MULTICRITÉRIO DE APOIO À DECIÃO CONSTRUTIVISTA

4.1 IDENTIFICAÇÃO DO CONTEXTO DECISÓRIO

4.1.1 IDENTIFICAÇÃO DOS ATORES

4.1.2 TIPO DE AÇÃO A SER AVALIADA

4.1.3 TIPO DE AVALIAÇÃO A SER FEITA ATRAVÉS DO MODELO

4.2 DESCRITORES PARA CONSTRUÇÃO DOS CRITÉRIOS

4.3 APLICAÇÃO DOS QUESTIONÁRIOS

4.4 APLICAÇÃO DO SOFTWARE DE MODELAGEM COM BASE NO MCDA-C

5. ANÁLISE DA PERCEPÇÃO DOS SISTEMAS DE TRANSPORTE INDIVIDUAL DE PASSAGEIROS

5.1. INFORMAÇÕES SOCIOECONÔMICAS

5.2 OPERAÇÃO

5.3 VALORES

5.4 SUPORTE

5.6 COMPARAÇÃO DO DESEMPENHO GERAL DOS SISTEMAS DE TRANSPORTE INDIVIDUAL DE PASSAGEIROS NO DF: TÁXI E UBER

6. CONCLUSÃO

REFERÊNCIAS BIBLIOGRÁFICAS

APÊNDICE A - FORMULÁRIO DE DEFINIÇÃO DOS PVF's e SUBPFV's E TAXAS DE SUBSTITUIÇÃO JUNTO AOS ESPECIALISTAS (BRAINSTORMING)

APÊNDICE B - FORMULÁRO DE DEFINIÇÃO DE NÍVEL DE ESFORÇO 90 APÊNDICE C - QUESTIONÁRIO IMPRESSO $\quad 91$

APÊNDICE D - QUESTIONÁRIO ONLINE (UBER) 92

APÊNDICE E - QUESTIONÁRIO ONLINE (TÁXI) 104

APÊNDICE F - MATRIZES SEMÂNTICAS E POSIÇÃO DA MEDIANA (TÁXI) 116 APÊNDICE G - MATRIZES SEMÂNTICAS E POSIÇÃO DA MEDIANA (UBER) 123 


\section{LISTA DE TABELAS}

Tabela 2.1 - Proporção de habitantes por veículos no DF .23

Tabela 2.2 - Variação entre quantidade de veículos existentes no DF entre junho/2013 e junho 2014. .24

Tabela 2.3 - Demonstrativo dos aumentos da frota de táxi do Distrito Federal..........................27

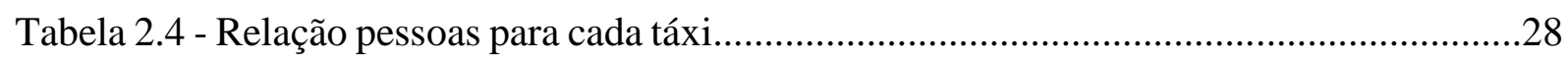

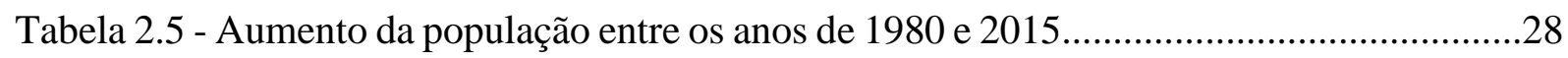

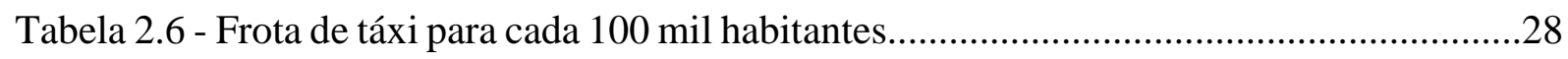

Tabela 2.7 - Frota de táxi nas 10 capitais mais populosas do Brasil..........................................29

Tabela 2.8 - Tarifas do serviço de táxi do DF............................................................................

Tabela 2.9 - Tabela de tarifas do serviço UberBlack...................................................................34

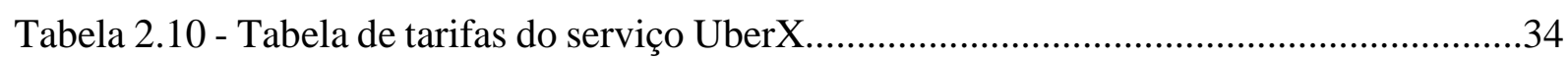




\section{LISTA DE FIGURAS}

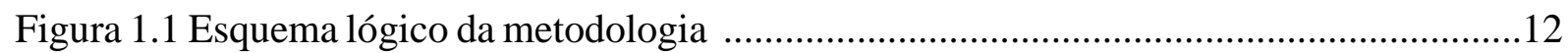

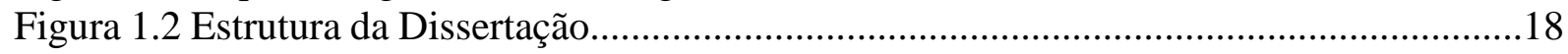

Figura 2.1 Evolução da frota de veículos no Distrito Federal.................................................24

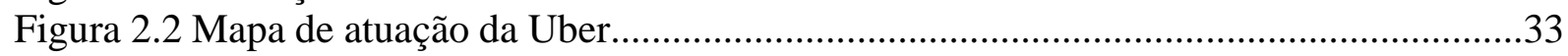

Figura 3.1 Curva conceitual dos componentes de usabilidade segundo Jordan (1998)...........46

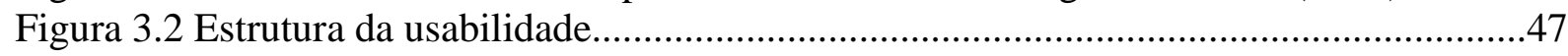

Figura 4.1 Atores do processo de percepção de qualidade do serviço de transporte individual de

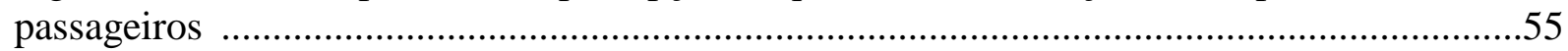

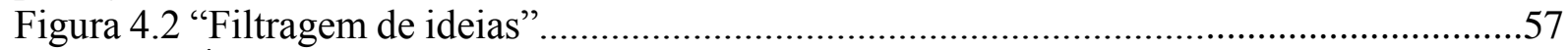

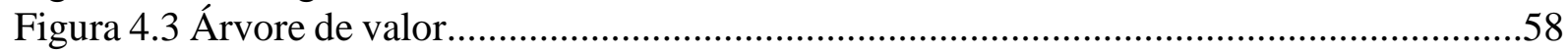

Figura 4.4 Estados do descritor em função do nível de atratividade.......................................61

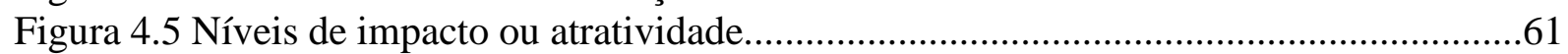

Figura 4.6 Inserção do rótulo da pesquisa no software..........................................................65

Figura 4.7 Inserção dos nomes atribuídos a cada Critério (PVF) e Subcritérios (SubPVF)........65

Figura 4.8 Inserção das taxas de contribuição no MAMADecisão...........................................66

Figura 4.9 Exemplo de marcação da posição da mediana no software.....................................66

Figura 4.10 Ajuste da Matriz Semântica (simétrica)...............................................................67

Figura 4.11 Cálculo do desempenho do Subcritério "1.1 Exigência Profissional" para táxi......67

Figura 5.1 Gráfico de desempenho do Critério "1. Operação" para os serviços de táxi e Uber...71

Figura 5.2 Gráfico de desempenho do Critério "2. Valores" para os serviços de táxi e Uber.....72

Figura 5.3 Gráfico de desempenho do critério "3. Suporte" para os serviços de táxi e Uber......74

Figura 5.4 Gráfico de desempenho do critério "4. Segurança" para os serviços de táxi e Uber..75

Figura 5.5 Gráfico de usabilidade dos Serviços de táxi e Uber...............................................77

Figura 5.6 Desempenho médio final para cada Critério avaliado..............................................77

Figura 5.7 Desempenho médio final dos Sistemas de Transporte Individual de Passageiros do

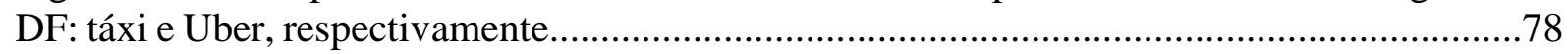




\section{LISTA DE QUADROS}

Quadro 3.1 Medidas de avaliação de qualidade em transporte coletivo urbano.

Quadro 3.2 Indicadores de qualidade e os motivos da sua não utilização pelos mercados de

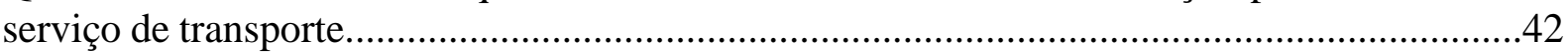

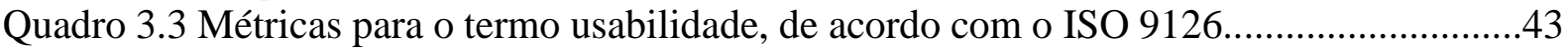

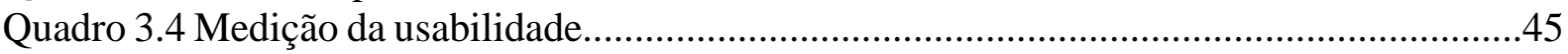

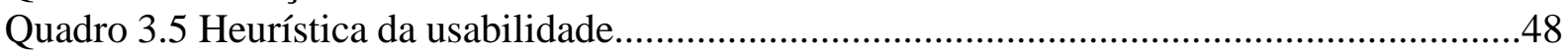

Quadro 4.1 Elementos Primários de Avaliação.......................................................................56

Quadro 4.2 Homologação dos PVF e taxa de substituição pelos decisores.................................59

Quadro 4.3 Resumo da percepção dos usuários sobre a qualidade do transporte individual de

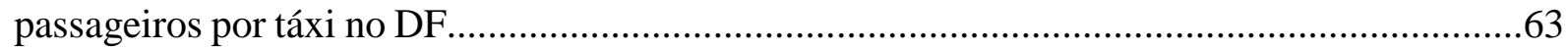

Quadro 4.4 Resumo da percepção dos usuários sobre a qualidade do transporte individual de

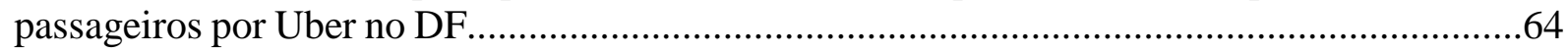

Quadro 5.1 Usuários de cada tipo de serviço, separados por sexo e faixas etárias......................68

Quadro 5.2 Usuários divididos por faixas de renda.............................................................69

Quadro 5.3 Usuários divididos por grau de escolaridade.......................................................69

Quadro 5.4 Percentual de usuários que dominam compras na web e que já utilizou rádio táxi...70

Quadro 6.1 Comparativo entre objetivos e resultados da pesquisa. 


\section{LISTA DE SIGLAS E ABREVIATURAS}

ANTP - Associação Nacional de Transportes Públicos

ArPDF - Arquivo Público do Distrito Federal

CLDF - Câmara Legislativa do Distrito Federal

$\mathrm{CF}$ - Constituição Federal

CF/88 - Constituição Federal de 1988

DAM - Decisão Acesso e Movimentação

DF - Distrito Federal

DTC - Departamento de Tráfego e Concessões

EPA - Elemento Primário de Avaliação

EUA - Estados Unidos da América

GDF - Governo do Distrito Federal

IBGE - Instituto Brasileiro de Geografia e Estatística

LMU - Lei de Mobilidade Urbana

MCDA-C - Método de Análise Multicritério de Apoio à Decisão gerencial com abordagem

Construtivista

MP - Medida Provisória

NOVACAP - Companhia Urbanizadora da Nova Capital do Brasil

PDTU - Plano Diretor de Transporte Urbano e Mobilidade

PTU - Programa de Transporte Urbano

PTU/DF - Programa de Transporte Urbano do Distrito Federal

PVE - Ponto de Vista Elementar

PVF - Ponto de Vista Fundamental

SEMOB - Secretaria de Estado de Mobilidade do Distrito Federal

SINPETAXI/DF - Sindicato dos Permissionários de Táxis e Motoristas Auxiliares do Distrito

Federal

SSP - Secretaria de Serviços Públicos

STF - Supremo Tribunal Federal

STIP - Sistema de Transporte Individual Privado

STPI - Sistema de Transporte Público Individual

STPP - Sistema de Transporte Público de Passageiros

SubPVF - Subponto de Vista Fundamental

SUFISA - Subsecretaria de Fiscalização, Auditoria e Controle do Distrito Federal

TCDF - Tribunal de Contas do Distrito Federal 


\section{INTRODUÇÃO}

O tema "transporte individual de passageiros" tem relevância para a mobilidade, porém, os estudos sobre transporte, em geral, valorizam a temática do "transporte coletivo", pois possui impactos maiores à população.

A exploração do transporte individual por táxi estava numa posição de estabilidade e isenta de disputa ou conflito de interesse socialmente relevante envolvendo o sistema de produção de riqueza nesse campo da economia, ou do trabalho, até o surgimento do serviço de transporte privado individual por meio de utilização de novas tecnologias.

Apenas recentemente, após a criação e deflagração do sistema Uber de transporte individual, que funciona como uma espécie de "carona paga", criado por um indivíduo americano, cuja prática espalhou-se mundo afora, é que a focalizada questão social veio à tona, gerando conflito social e econômico, com a "explosão" da novidade na mídia eletrônica, falada, televisada e escrita, que mexeu especialmente com os interesses da classe dos taxistas de diversas cidades brasileiras e do mundo.

Antes dessa ocorrência, porém, falava-se muito em problemas relacionados com o "transporte de passageiro" mas quase que exclusivamente no âmbito do "transporte coletivo",

Por isso são de grande valia a pesquisa, o estudo, a reflexão, a análise crítica e eventuais propostas de solução para a questão relativa ao transporte individual de passageiros no contexto dos transportes urbanos, diante do modelo que desponta no nosso meio, sobretudo diante da possibilidade de mudança significativa na quantidade, ou mesmo na qualidade, da frota particular de automóveis em compartilhamento de uso.

A importância do estudo do transporte individual de passageiros no contexto dos transportes urbanos, apresenta-se quando é tratada a possibilidade de redução da frota particular de carros com o compartilhamento de veículos e propicia o uso mais otimizado do veículo.

Devido à introdução recente de novas tecnologias para a prestação do serviço de transporte individual de passageiros, seja de característica pública ou privada, ainda não houve o aprofundamento nem de natureza doutrinária, nem de natureza jurisprudencial, nem de natureza legislativa sobre o assunto, muito menos sobre o tema delimitado. Ratificado pela recente inserção da tecnologia utilizada pela Uber no Brasil, ocorrida em 15 de maio de 2014. 
Devido a sua recente inserção no mercado, a prestação de serviços de transporte por meio da utilização de smartphones se mostra carente de regulamentação, fato que tem gerado constantes conflitos da categoria dos taxistas com os prestadores desse novo serviço, especificamente o Uber, o que torna necessária a ação do gestor público.

Dias (2007) afirma sobre a necessidade da regulação dos serviços de táxi, devendo, para tanto, enquadrá-los na lista dos serviços públicos que necessitam de intervenção estatal na sua prestação. Portanto, a importância deste estudo recai diretamente no fato de que o serviço de transporte individual privado, por meio de motoristas particulares, acaba por gerar conflitos e disputas pela mesma clientela dos táxis.

\subsection{APRESENTAÇÃO}

Acerca da importância do transporte na sociedade brasileira, sob o aspecto legal, temos diversos instrumentos legais, constitucionais e infraconstitucionais, que dispõem sobre o assunto.

Em relação ao transporte individual de passageiros, somente aquele de caráter público encontrase referenciado na Lei $\mathrm{n}^{\circ} 12.587 / 2012$, enquanto o privado ainda não foi regulamentado, até o momento, apesar da existência do Projeto de Lei da Câmara dos Deputados no 3.384/2015 o qual pretende a sua regulamentação.

Segundo a justificativa do supra referido Projeto de Lei, o transporte individual privado de passageiros trouxe "notória melhoria para a população em geral, haja vista que o serviço prestado é focado no cliente, perpetua os bons prestadores e estimula a melhoria do serviço a partir da avaliação da qualidade do atendimento e do conforto", citando, inclusive, o conflito de interesses entre taxistas e Uber.

A partir dessa afirmativa, surge a dúvida acerca da real diferença de qualidade entre os dois serviços de transporte individual, aquele prestado por táxi e o prestado pelo Uber, de forma que houve a necessidade de quantificar qualidade a partir da percepção dos usuários e de acordo com os critérios mais relevantes estabelecidos pelos gestores/especialistas de ambos serviços sobre o que entendem por qualidade.

Assim, a ferramenta Metodologia Multicritério de Apoio à Decisão - Construtivista (MCDAC) é de grande valia para a referida avaliação da qualidade sob o ponto de vista do próprio usuário dos serviços. 


\subsection{PROBLEMA}

A Lei $n^{\circ}$ 8.987/1995 - Lei de Concessões e Permissões dos Serviços Públicos trata das formalidades e características mínimas a serem atendidas pelos concessionários para prestarem o serviço público de forma adequada, logo, todo o serviço de transporte público no país deve obedecê-la. A adequabilidade do serviço deve se adaptar às novas necessidades e tecnologias disponíveis, sendo necessário ir além das formalidades e características mínimas para atendimento aos passageiros, conforme foi previsto na Lei.

Diante da necessidade de atender a uma parcela da população cada vez mais exigente, e devido ao surgimento de novas opções de transporte individual de passageiros proporcionadas pelo constante avanço tecnológico no dia a dia das pessoas, essa pesquisa procura identificar se há necessidade além daquela definida como "serviço adequado". Pretende-se aferir a percepção da qualidade dos sistemas de transporte individuais de passageiros táxi e Uber.

A percepção de qualidade por parte de usuários dos sistemas pôde ser verificada a partir da grande repercussão divulgada em meios de comunicação, manifestações em redes sociais e, inclusive, chegando o assunto a ser debatido nas casas legislativas, por exemplo, a Câmara dos Deputados, o Senado Federal e a Câmara Legislativa do Distrito Federal, verificado por meio das justificativas contidas nas proposições de Projetos de Leis.

A partir da necessidade de construir indicadores de qualidade dos serviços de transporte individual de passageiros, serão consideradas a percepção e a perspectiva que o usuário possui acerca da prestação do serviço, visto que ele é o destinatário, não se limitando ao que a legislação definiu como "características mínimas para o fornecimento de um serviço adequado".

A Lei de Concessões e Permissões trata apenas da possibilidade de delegação de serviços públicos a particulares, para que estes exerçam, por sua conta e risco, a atividade econômica. Nessa perspectiva, deixou de abordar a possibilidade da prestação de serviços particulares que possam conflitar com o interesse público.

O caso do transporte individual particular de passageiros é um exemplo que ilustra a situação acima mencionada. Este conflita com o interesse público, delegado por autorização do Poder Público aos prestadores de serviço de táxi, que, por sua vez, gera conflitos de interesse entre as duas categorias. 
Ocorre que a prestação do serviço adequada deve ser aferida pelo usuário do sistema. Este sim é capaz de informar se o serviço está sendo prestado adequadamente, de acordo com suas expectativas, e quais melhorias seriam necessárias.

Assim, a avaliação do nível de qualidade prestado pelos dois tipos de serviço pode remeter aos principais itens ou quesitos que satisfazem o conceito de "serviço adequado" previsto na Lei de Concessões e Permissões.

O serviço oferecido aos passageiros por meio de aplicativos, por exemplo o Uber, traduz o atual momento de migração do sistema de táxi comum para se adequarem à tecnologia cada vez mais acessível aos usuários do sistema. Dentro dessa perspectiva a pesquisa visa responder, principalmente, as seguintes perguntas: Quais os itens de qualidade que mais atraem os usuários dos serviços de transporte individual de passageiros? Qual a percepção de qualidade que os usuários desses sistemas estão tendo? Essa percepção corresponde às expectativas dos gestores/especialistas?

\subsection{OBJETIVOS}

O objetivo geral da pesquisa é identificar a percepção da qualidade dos transportes público e privado individuais do DF, pelos usuários, com base nos aspectos relevantes para gestores e especialistas, a partir da participação deles em brainstorming (tempestade de ideias), a fim de chegarem a um consenso sobre os assuntos discutidos.

Os objetivos específicos estruturam o trabalho e permitem o alcance do objetivo principal. A presente proposta de pesquisa tem como objetivos específicos:

i) Caracterizar os serviços de transporte individual de passageiros: público (táxi) e privado (Uber) a partir de pesquisa na literatura e legislação;

ii) Diagnosticar os sistemas de transporte individual público e privado do DF;

iii) Conceituar qualidade e usabilidade e estabelecer parâmetros, de acordo com critérios definidos pelos gestores e especialistas da área, para identificar a qualidade dos serviços prestados nos dois sistemas de transporte, sob o ponto de vista dos usuários;

iv) Comparar as percepções dos usuários sobre os serviços de táxi e do Uber. 


\subsection{JUSTIFICATIVA}

Acerca do transporte de maneira geral verifica-se que não há exigência constitucional expressa para que ocorra a regulação do serviço de transporte individual e, talvez por isso, até a publicação da Lei $n^{\circ}$ 12.587/2012, o tema táxi não estava incluso nos Planejamentos e Programas que envolvem o desenvolvimento do transporte regional.

A falta de exigência constitucional para o tema transporte individual é verificada devido a consistir em um serviço diferenciado de transporte e não possuir como público-alvo a população com menos recursos financeiros, como o ocorrido com o transporte público coletivo, este último também chamado popularmente de transporte de massa.

Ferraz e Torres (2001) afirmam que o táxi constitui um modo de transporte de grande relevância para a sociedade, pois proporciona flexibilidade de horários e as mesmas rotas utilizadas por carros particulares, porém, possuindo características importantes e que proporcionam conforto ao usuário, tais como a não propriedade do veículo, a não necessidade de dirigir e de estacionar.

Deve-se atentar para o fato de o táxi também se constituir em um meio importante de transporte, pois possui o objetivo de suprir uma necessidade pública (ANTP, 1997), ao passo em que se constitui em uma alternativa mais eficiente, sob o aspecto da qualidade e personificação do atendimento, do que o transporte público regular, devido a suas características típicas encontradas no transporte privado individual, porém com acesso mais restrito, devido ao fator limitador "renda".

Para Kang (1988), apud Dias (2007), os serviços de táxi são denominados paratransit, por terem características que estão entre carros e ônibus. Esse tipo de serviço restringe a acessibilidade do público em geral, por ter uma tarifa elevada em relação a outros transportes públicos de massa.

Segundo definição de Cervero (1997), paratransit foi um termo criado na década de 1970 para descrever melhor a definição de transporte existente entre o automóvel privado e o ônibus convencional. Assim como o automóvel, esses serviços são flexíveis e ubíquos, ou seja, podem ir a qualquer lugar.

Por ser considerado de utilidade pública, compete ao Poder Público municipal seu planejamento e regulamentação (ANTP, 1997). Reck (2016) afirma que no caso do transporte particular a 
atuação do poder público se restringe à implantação do sistema viário, à regulamentação do seu uso e ao controle operacional do trânsito em geral.

A organização, disciplina e fiscalização deste serviço, sob o aspecto legal, foram inseridas no texto do art. 12 da Lei de Mobilidade Urbana, o qual estabelece que devem ser realizados pelo poder público municipal. Ou seja, entendeu-se que o serviço de táxi é um "serviço público de interesse local", conforme interpretação dada pelo art. 30, V da Constituição Federal de 1988.

O texto da Lei $\mathrm{n}^{\circ}$ 12.587/2012 classifica o serviço de táxi como "serviço de utilidade pública de transporte individual", sendo tratado no Distrito Federal como um "Serviço de Transporte Público Individual de Passageiros". Por sua vez, não possui a mesma característica de prover meios de equidade à população de determinado território, em relação ao serviço de transporte coletivo urbano, porém, possui um papel importante na formação da configuração da malha viária urbana das cidades, pois é um meio de transporte público que prioriza o conforto, o tempo e maior mobilidade, destinado à população mais exigente.

O táxi difere das características de outros meios de transporte público devido a sua grande capacidade de "personalização" dos interesses de deslocamento, via prestação de serviço “porta-a-porta”. Nesse sentido, Reck (2016) afirma que no transporte particular o usuário tem uma participação ativa, ao passo em que no transporte público a participação se apresenta de forma passiva.

Essa característica de atender a outro segmento da população, também acaba atendendo, de forma indireta, à necessidade de prover a qualidade de vida aos usuários do transporte, bem como contribui para a melhoria da mobilidade e redução de carros nas vias urbanas. Cardoso e Matos (2007) afirmam que a mobilidade satisfatória aumenta a qualidade de vida populacional. Assim, a disponibilização do serviço pode servir de incentivo às pessoas para não adquirirem seus próprios veículos automotores e trocarem pelo Táxi, de modo a conservar o mesmo conforto e reduzindo a quantidade de veículos nas ruas, com consequente redução do trânsito e melhoria da mobilidade e qualidade de vida.

Kneib (2012), apesar de tratar mais a fundo sobre o tema mobilidade urbana, trata principalmente da necessidade de quebra do paradigma, cercado pela cultura, acerca da valorização da propriedade do automóvel e da organização do território de forma articulada com os demais sistemas para minimizar a necessidade dos deslocamentos e potencializar o aproveitamento dos sistemas de transporte e das redes existentes. 
Meeberg (1993), apud Kluthcovsky et. al. (2007), afirma que o termo "qualidade de vida" passou a ser muito utilizado após a Segunda Guerra Mundial, com a noção de sucesso associada à melhoria do padrão de vida, principalmente relacionado com a obtenção de bens materiais, como casa própria, carro, salário e bens adquiridos. Essa foi talvez a primeira manifestação de que ser proprietário de automóvel significaria ter qualidade de vida.

A partir de então, à medida que o capitalismo avança, a propriedade de um automóvel passou a ser considerado muito mais do que qualidade de vida, mas um status social. Nesse sentido, DaMatta (2010) afirmou que tanto o sentimento quanto o comportamento do dono podem variar segundo a marca e o modelo do automóvel, que no Brasil são elementos de distinção de superioridade social.

Os serviços de transportes individuais, sejam públicos ou privados, possuem papel importante na potencialização da utilização dos sistemas de transportes disponíveis, principalmente em relação à sua contribuição para a retirada de circulação de automóveis de propriedade particular, e que, muitas vezes, transitam pelas ruas com apenas uma pessoa.

Em relação à prestação do serviço de transporte público individual à população, a Lei $n^{\circ}$ 8.987/1995, chamada de Lei de Concessões e Permissões, estabelece diretrizes gerais aos serviços de táxi prestados no território brasileiro. Devido à caracterização do Táxi como um serviço público, este se encaixa no tipo previsto no art. $2^{\circ}$, IV da supracitada Lei, pois se trata de delegação concedida a pessoas físicas ou jurídicas que, em tese, deveria ser procedida por meio de licitação, e essas pessoas deveriam demonstrar capacidade para o desempenho da função por sua conta e risco.

A Lei de Concessões e Permissões conceitua, em seu art. $6^{\circ}, \S 1^{\circ}$, "serviço adequado" como aquele que satisfaz as condições de regularidade, continuidade, eficiência, segurança, atualidade/modernidade de técnicas, generalidade, cortesia na sua prestação e modicidade de tarifa. Dentre outras, esta é uma das obrigações que esses prestadores de serviço devem cumprir.

Os serviços de táxi têm perdido em qualidade ao longo dos anos, e isso se deve a diversos fatores, que serão explicitados a seguir, tais como: a concentração das autorizações de Táxi nas mãos de poucos (oligopólio); o mercado fechado e pouco competitivo; a falta de regulação adequada; a falta de fiscalização; a inexistência de controle de qualidade do serviço prestado; a existência de sindicatos fortes e resistentes a mudanças; e a proteção demasiada do Estado em relação aos prestadores de serviço. 
De um lado, Dias (2007) cita que a regulamentação estatal teria sido responsável pela criação de monopólios e oligopólios protegidos em sua ineficiência, em detrimento do interesse público e em favor do regulado. Por outro, Baer (2009) descreve que no Brasil há um sistema de empresas, sindicatos e governo que controla o mercado.

Nesse sentido, foi possível verificar a influência dos sindicatos dos taxistas quando ocorreu aprovação da Medida Provisória nº 615/2013, momento em que a Presidenta da República, compareceu, pessoalmente, ao Sindicato dos Permissionários de Táxis e Motoristas Auxiliares do Distrito Federal - SINPETAXI/DF, para sancionar a referida MP, conforme publicado na mídia.

A Medida Provisória, que posteriormente foi convertida na Lei $\mathrm{n}^{\circ} 12.865 / 2013$, autorizou a transferência aos herdeiros do taxista titular a exploração do serviço de táxi e possibilitou a perpetuação do serviço nas mãos de determinadas famílias, ao passo em que a Lei de Concessões e Permissões prevê a licitação demonstração de capacidade de desempenho.

Acerca do oligopólio dos taxistas, Kang (1998) afirma que é possível a sua ocorrência em duas situações: em pequenas cidades e zonas rurais, quando não há a prestação adequada dos serviços substitutos, tais como ônibus e metrô; e no caso de supervalorização da licença: quando o mercado é fechado.

Verifica-se que há a incidência dessa segunda hipótese, de supervalorização da licença, no caso do Distrito Federal, ao passo em que os diversos obstáculos impostos pela própria categoria resultam na estagnação do número de licenças e consequente aumento demasiado no seu valor para os que querem ingressar. De certo modo, a resistência da categoria em aumentar a quantidade de táxi pode ser explicada pelo fato de que o acréscimo do número de autorizações de táxi pode significar uma redução dos ganhos individuais, devido ao compartilhamento do mercado (Orr, 1969)

Com os avanços tecnológicos cada vez mais presentes em nosso cotidiano, os serviços de táxi acabaram afetados, mexendo, inclusive, nas estruturas da fortaleza formada em torno dos atuais detentores das outorgas. É o caso das manifestações dos taxistas ocorridas em várias cidades e apoiadas pelos seus respectivos sindicatos, conforme divulgado em larga escala na mídia.

Oliveira e Tybusch (2015) dizem que, "com a evolução da sociedade, o homem passou a transformar seu modo de viver, principalmente a partir da incorporação de tecnologias no 
cotidiano, as quais passaram a facilitar as atividades diárias e contribuíram para o aumento da expectativa de vida da população". Parece que a sociedade, cada vez mais exigente e com mais recursos disponíveis às suas mãos, pois está “conectada" por meio de seus smartphones, buscará por serviços que melhor atendam às suas demandas, com o objetivo de facilitar as atividades diárias. É nesse momento que surge a oportunidade de avaliar os serviços do Táxi e do Uber.

Nesse sentido, a presente pesquisa pretende contribuir para identificar itens de qualidade mais relevantes para os passageiros que utilizam os dois sistemas de transporte individual da capital federal, a fim de apresentar o perfil de desempenho de ambos.

\subsection{METODOLOGIA DA PESQUISA}

A metodologia utilizada na construção do modelo para investigar a percepção de qualidade do transporte individual de passageiros do Distrito Federal: Táxi e Uber, de acordo com 5 (cinco) níveis de serviço foi desenvolvida em cinco etapas: identificação do contexto decisório; estruturação do problema; estruturação do modelo; estudo de caso; e análise e discussões.

\section{$1^{\text {a }}$ Etapa - Identificação do contexto decisório}

Foram identificados: os atores envolvidos no processo decisório; o tipo de ação a ser avaliada; e a escolha da problemática.

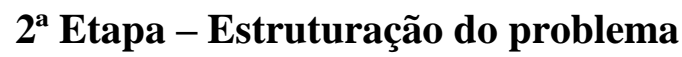

A estruturação do problema foi dividida em 2 fases:

\section{$1^{\text {a }}$ fase - Contextualização e levantamento bibliográfico}

Nesta fase houve a contextualização do fenômeno e o objeto estudado por meio de revisão bibliográfica acerca do histórico e funcionamento de cada um dos sistemas e, posteriormente, levantamento do referencial teórico sobre o tema "qualidade". Foi realizado por meio dos sítios eletrônicos governamentais; de consultas aos acervos de instituições governamentais, tais como Secretaria de Estado de Mobilidade - SEMOB e Arquivo Público do Distrito Federal - ArPDF; de bibliotecas online das universidades nacionais e estrangeiras; do acervo do Programa de Pós-Graduação em Transportes da Universidade de Brasília; de livros que abordem os temas: táxis, transporte individual 
público, transporte individual privado, aspectos jurídicos da prestação do serviço de transporte, qualidade, qualidade no transporte e do atendimento, entre outros.

O alvo desse levantamento bibliográfico foi pesquisar sobre a origem do serviço de transporte individual de passageiros no Distrito Federal, verificar os aspectos jurídicos dos dois tipos de serviço e buscar referencial teórico acerca de estudos realizados com o tema qualidade, especificamente na área de transportes.

\section{$2^{\mathrm{a}}$ fase - Levantamento do referencial teórico}

Foi realizada a pesquisa acerca do referencial teórico a ser utilizado como base para o trabalho. A pesquisa se baseou nos conceitos de "qualidade e usabilidade" ligados aos serviços de transporte.

\section{$3^{\text {a }}$ Etapa - Modelo Multicritério de Apoio à Decisão - MCDA-C}

A estruturação do modelo ocorreu em quatro fases:

$\mathbf{1}^{\mathbf{0}}$ fase: Construção da árvore de pontos de vista fundamentais;

$\mathbf{2}^{\mathbf{0}}$ fase: Construção dos critérios de avaliação;

$\mathbf{3}^{\mathbf{a}}$ fase: Determinar as taxas de substituição e os níveis de serviço do modelo.

\section{$4^{\text {a }}$ Etapa - Estudo de caso}

Foram selecionados os serviços de transporte público individual e individual privado do Distrito Federal. A pesquisa foi realizada por meio de aplicação de questionários junto aos usuários desses dois sistemas com o objetivo de verificar o grau de satisfação em relação ao serviço prestado.

\section{$5^{\text {a }}$ Etapa - Aplicação da modelagem e análise dos resultados}

Foi utilizado o software MAMADecisão para a aplicação do método MCDA-C. Após os resultados gerados pelo software, foi feita a análise dos resultados colhidos e promoção de discussão acerca da aplicação do método no estudo de caso. 


\subsubsection{DETALHAMENTO DA METODOLOGIA APLICADA}

Apesar do Sistema de Transporte Individual de passageiros do Distrito Federal ser o objeto da pesquisa e os passageiros desse sistema serem os sujeitos da pesquisa, foram sujeitos também da pesquisa os pesquisadores e especialistas da área de transportes e os servidores (técnicos) que trabalham na gestão, regulação e fiscalização desses Sistemas de Transporte, e suas contribuições foram fundamentais para identificar os critérios e subcritérios para comporem a base de dados da analise multicritério - construtivista (MCDA-C).

Rodrigues (2014) afirma que a utilização do modelo MCDA-C justifica-se por não ser um modelo pré-determinado, mas sim construído com base na tendência epistemológica Piagetiana e sua visão construtivista, pois trata o conhecimento como resultado da relação entre o sujeito e seu objeto de estudo.

Silveira Júnior (2015) ressalta que o método MCDA-C propõe a indicação de apenas "um dos caminhos que satisfaçam o problema em análise", que é definido a partir de um conjunto de parâmetros definidos pelos decisores que participam do processo de construção do modelo. Não se trata de estabelecer o melhor caminho possível como ocorre na pesquisa operacional tradicional.

Chamados de decisores, especialistas (pesquisadores e técnicos) sobre o assunto participaram ativamente da estruturação do problema, pois são os que melhor conhecem e, portanto, podem fornecer o conhecimento para gerar os quesitos necessários à avaliação e garantir o alcance dos objetivos desejados, que são, de maneira geral, a identificação dos itens de qualidade relevantes a serem "testados" pelos usuários de acordo com suas "percepções".

Para a definição desses itens, o pesquisador assumiu então o encargo de mediador do processo de construção dos resultados, os especialistas da área foram contribuintes da preparação do instrumento de coleta de dados e os usuários dos Sistemas de Transporte Individual: Táxi e Uber, contribuíram como respondentes. O esquema lógico da metodologia encontra-se descrito na Figura 1.1.

No esquema é apresentada a base da pesquisa, constituída pelo "Plano de pesquisa" e pelo "Referencial Teórico". Definidos essas duas bases, a próxima etapa é a identificação dos atores intervenientes da pesquisa: gestores, que foram representados pelos especialistas. Esses sujeitos são encarregados de definirem os critérios com base no objeto (neste caso é a 
"Percepção da usabilidade do Sistema de Transporte Individual do Distrito Federal") e o lócus da pesquisa (Sistemas de Transporte Individual do DF: Táxi e Uber), com a finalidade de estabelecerem critérios que serão avaliados pelos atores agidos (usuários dos sistemas).

Segundo Rodrigues et al (2016), os critérios de usabilidade definidos pelos atores intervenientes, através da Metodologia MCDA-C, são submetidos à avaliação dos atores agidos, por meio da coleta de dados (questionários), com a finalidade de obter informações acerca da percepção de qualidade do serviço prestado.

Após a coleta dos dados, por meio dos questionários respondidos, é realizada a tabulação dessas informações, de forma a quantificar as respostas dentro dos critérios qualitativos estabelecidos pelas opções de respostas dos questionários. Esses dados são inseridos no software MAMADECISÃO, que, após processá-los, fornece as informações a serem analisadas para a obtenção dos resultados da pesquisa.

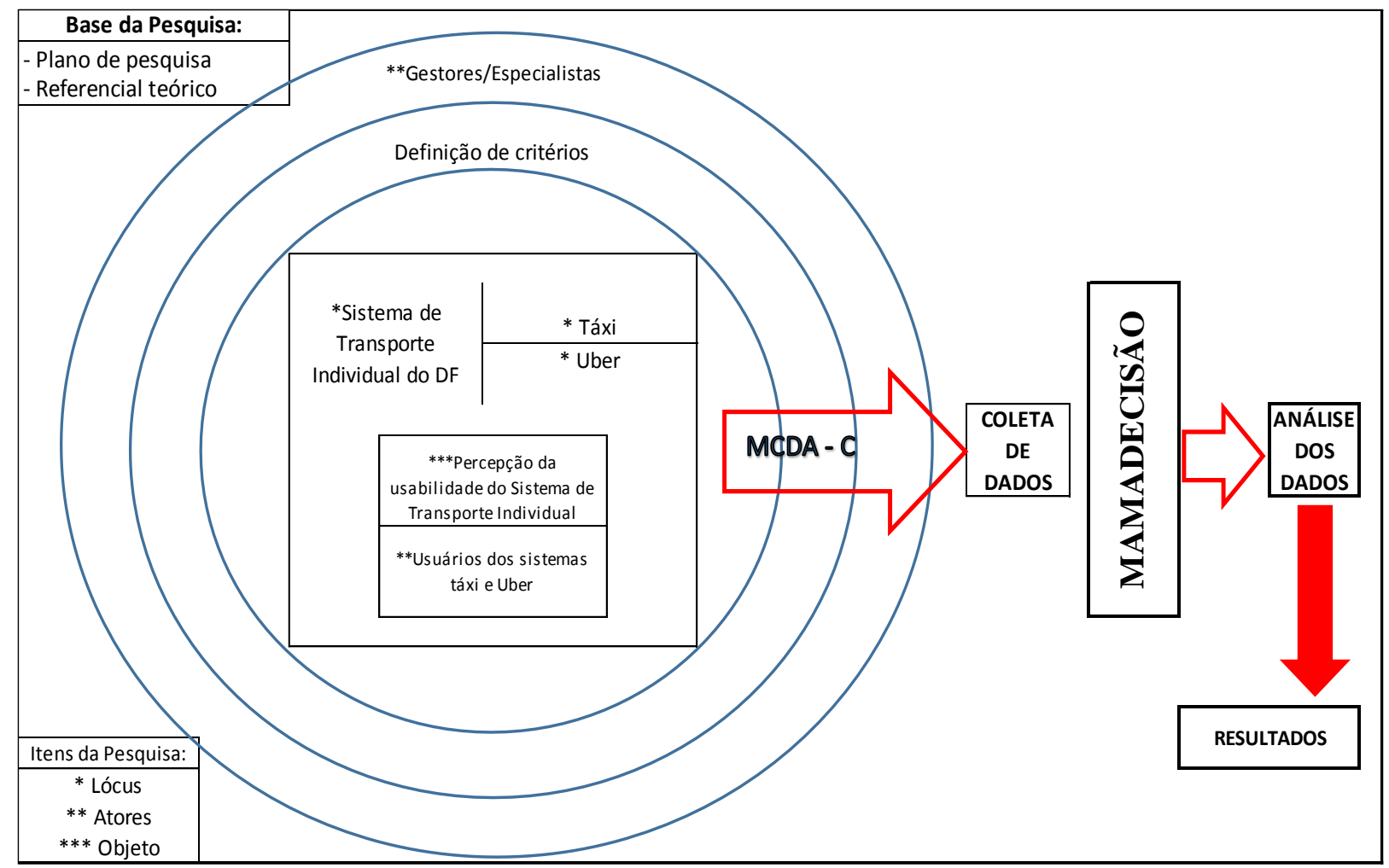

Figura 1.1 - Esquema lógico da metodologia

Fonte modificada: Rodrigues (2014); Ortega (2015) 
O passo-a-passo da metodologia MCDA-C aplicada consistiu no seguinte:

a) Foram realizadas entrevistas com pesquisadores da área e junto a servidores responsáveis pela gestão, regulação e fiscalização dos serviços de transporte individual do Distrito Federal, com a finalidade de entender as características do serviço e os aspectos que eles consideravam relevantes para a qualidade;

b) Após a identificação dos itens considerados relevantes sob o aspecto gerencial, iniciouse a segunda fase, momento em que foram discutidos e formatados os quesitos de qualidade definitivos a serem avaliados pelos usuários, de acordo com critérios e subcritérios, bem como definição dos pesos (ou níveis de esforço) relativos ao grau de importância de cada item para a composição da qualidade dos sistemas de transporte individual como um todo. Nesta etapa foi utilizada a técnica do brainstorming para se chegar a um consenso acerca da versão final dos itens que fariam parte da aplicação junto aos usuários (formulário aplicado no brainstorming disponível no Apêndice B).

c) Definidos os itens de qualidade a serem avaliados, foram elaborados dois questionários, um para a avaliação da percepção de qualidade do serviço táxi e outro para o Uber. Foram confeccionados dois questionários (um online, através da ferramenta Google Forms, e outro impresso) para cada um dos serviços avaliado.

Os questionários online foram divulgados por meio de e-mails e nas redes sociais, e os impressos foram realizados pessoalmente junto a potenciais usuários.

d) Os resultados da pesquisa de campo, desenvolvida por meio dos questionários, foram tabulados e inseridos no Software MAMADecisão, que gerou os gráficos e estes foram analisados e divulgados os resultados no corpo desse trabalho.

\subsubsection{CLASSIFICAÇÃO DA PESQUISA}

A pesquisa tem natureza observacional, com abordagem descritiva, constituída por pesquisa bibliográfica, entrevistas com gestores e/ou pesquisadores, dados coletados em pesquisa de campo e, posteriormente, análise dos dados de forma qualitativa e quantitativa.

Silva e Menezes (2001) conceituam a pesquisa observacional como aquela em que o pesquisador atua como expectador do fenômeno estudado, sem interferir ou participar dos fatos, embora possa realizar mediações, análises e outros procedimentos para coleta de dados. 
Quanto à natureza, essa pesquisa consiste na combinação entre quantitativa e qualitativa, à medida em que serão utilizados critérios qualitativos e transformados em itens mensuráveis (quantitativos).

Para êxito no desafio de compreender quais são os quesitos de qualidade que mais importam aos usuários do sistema, é necessário elaborar uma metodologia capaz de investigar a percepção de qualidade de ambos os sistemas de transporte individuais analisados: Táxi e Uber.

A finalidade é viabilizar a comparação entre o atual serviço de táxi, que é regulamentado, com o serviço oferecido de forma aberta, sem a regulamentação pelo Estado, o qual tem sido alvo de diversos questionamentos acerca da sua legalidade e também objeto de manifestações tanto a favor quanto contra a sua utilização como meio de transporte.

\subsubsection{POPULAÇÃO E AMOSTRA}

A população abordada por este estudo é composta de habitantes que utilizam o sistema de transporte individual de passageiros, seja Táxi ou Uber, e residentes no Distrito Federal. Foram realizadas consultas junto ao SINPETAXI/DF e junto à empresa Uber, esta última por meio eletrônico, sobre qual seria a quantidade de passageiros transportados diariamente, porém, o Sindicato não detinha estudo sobre essa quantidade, e não obtivemos resposta da Uber, portanto, realizamos a amostragem a partir da população total existente no DF. Para contextualizar, atualmente a população residente nesta Unidade da Federação está estimada em aproximadamente 2.852.372 (IBGE, 2014).

Devido à grande quantidade de pessoas no universo a ser avaliado, é inviável a realização de um censo. Por isso, a pesquisa utilizou o processo de amostragem, com a finalidade de colher parcela representativa da população. A pesquisa utilizou a amostra aleatória simples, segundo a qual todos os membros da população têm a mesma chance de terem seus dados coletados.

Santos (2016) demonstra que é necessária uma amostra de 385 pessoas para se obter uma amostra populacional do Distrito Federal com erro amostral de 5\% e intervalo de confiança de 95\%, conforme a equação 1.1 (fórmula do cálculo amostral).

$$
n=\frac{N \cdot Z^{2} \cdot p \cdot(1-p)}{Z^{2} \cdot p \cdot(1-p)+e^{2} \cdot(N-1)}
$$


Onde:

$\mathrm{n}$ - o tamanho da amostra desejada

$\mathrm{N}$ - população ou universo

$\mathrm{Z}$ - desvio do valor médio aceitável para alcançar o nível de confiança desejado

$\mathrm{p}$ - verdadeira probabilidade do evento ou proporção que se espera encontrar $(=50 \%)$

e - margem de erro máxima admitida

Quando se trabalha com um universo de tamanho muito grande (a partir de 100.000 indivíduos) essa fórmula pode ser simplificada pela equação 1.2 a seguir:

$$
\mathrm{n}=\frac{Z^{2} \cdot p \cdot(1-p)}{\mathrm{e}^{2}}
$$

Onde:

$$
\mathrm{n}=1,96^{\wedge} 2 * 0,5 *(1-0,50) /\left(0,05^{\wedge} 2\right)=384,16
$$

Fonseca et al. (2015) utilizaram amostra de 150 questionários para avaliarem a qualidade do sistema de transporte coletivo de Brasília, para a quantidade de 419.999 .665 passageiros transportados no período de um ano. Afirmam que essa quantidade de respondentes atende, a partir da mediana das respostas, à concentração de respostas a respeito da qualidade avaliada por meio do software de modelagem para análise multicritério de apoio à decisão.

Considerando a frota de 3400 táxis do Distrito Federal, devido a não haver informações disponíveis acerca da quantidade de passageiros/dia para o serviço de transporte individual de passageiros do Distrito Federal, entendemos prudente utilizarmos o mesmo tamanho da amostra realizada para o sistema de transporte coletivo de Brasília.

A prudência reside no fato de que, se realizarmos o cálculo alocando a mesma quantidade de passageiros/ano do sistema de transporte coletivo para o quantitativo da frota do DF, teríamos, em média, 338 passageiros por dia/táxi, o que já seria um exagero. Porém, optamos por essa amostra mínima de 150 questionários.

\subsubsection{PLANO DE COLETA DE DADOS}

O plano de coleta dos dados foi realizado por meio de diversos contatos com servidores das áreas de gestão, regulação e fiscalização do transporte individual do Distrito Federal e pesquisadores em transportes, ocasiões em que foram coletados dados relevantes sobre estrutura e qualidade dos serviços, bem como eventuais pontos fracos e fortes da prestação dos serviços e que auxiliaram a formular os Elementos Primários de Avaliação - EPAs. 
Após formatados os EPAs, foi realizada reunião com os especialistas para definição das variáveis de usabilidade, bem como seus critérios e subcritérios, que compuseram o instrumento de coleta de dados aplicado aos usuários. Foram estabelecidas as seguintes variáveis de usabilidade: operação, valores, suporte e segurança.

Considerando que o rótulo da pesquisa é sobre a percepção de qualidade, foi estabelecido entre os especialistas que a quantidade mínima de utilizações dos sistemas deveria ser 03 (três), quantia suficiente para a percepção adequada dos quesitos de qualidade estabelecidos no instrumento de coleta. Também ficou estabelecido que os usuários participantes deveriam ter pelo menos 18 (dezoito) anos, idade considerada como limiar da maioridade civil.

Foi sugerida, ainda, a inclusão de duas variáveis que poderiam influenciar na percepção da qualidade dos serviços: se os respondentes possuem facilidade em realizar transações pela plataforma web e se já tiveram a oportunidade de utilizar o serviço do rádio-táxi. A primeira variável seria para identificar se eventual dificuldade em utilizar serviços de web commerce teriam correlação com o manuseio do aplicativo Uber; a segunda variável teria o objetivo de verificar qual é o percentual de usuários do Uber que já utilizaram o serviço de rádio táxi, que é um serviço que costuma prestar maior assistência ao usuário, pois costuma estar atrelado à uma empresa ou cooperativa.

\subsubsection{PLANO DE ANÁLISE DE DADOS}

A análise de dados foi realizada por meio da utilização de software que se encarregou de transformar dados qualitativos, em relação a informações subjetivas de percepção dos usuários dos sistemas de transporte individual de passageiros do DF, em quantitativos

Foram analisados os gráficos das avaliações de percepção de qualidade do táxi e do Uber de forma individualizada e, posteriormente, foram sobrepostos para avaliação do contexto em relação aos seguintes níveis de serviço: excelente, muito bom, bom, indiferente e ruim ou inexiste o serviço.

Os parâmetros de avaliação mínimo e máximo foram delimitados pelo software, e o objeto da análise dos dados foi identificarmos qual(ais) o(s) menor(es) esforço(s) necessário(s) para subir de nível de serviço. 


\subsection{ESTRUTURA DA DISSERTAÇÃO}

A dissertação está organizada em seis capítulos, além das referências bibliográficas e apêndices.

Capítulo 1 - Introdução. Este capítulo conta com uma apresentação, o problema, os objetivos, a justificativa, a metodologia utilizada na construção do modelo e a estrutura da dissertação.

Capítulo 2 - Histórico e Contextualização do Transporte Individual de Passageiros. É realizada uma breve revisão bibliográfica, contendo o histórico de ambos os sistemas (Táxi e Uber), as características da prestação dos serviços e a importância de avaliar a sua qualidade.

Capítulo 3 - Posteriormente, é abordado o estado da arte da Gestão da Qualidade, mostrando sua aplicação no campo de serviços, especificamente nos serviços de transporte, e de forma a se aproximar à questão da qualidade no âmbito do transporte "individual” de passageiros.

Capítulo 4 - Construção do modelo para classificar os serviços de Transportes Individuais Público (Táxi) e Privado (Uber), por nível de serviço, ocasião em que foram identificados os indicadores utilizados para aferir a qualidade do transporte de passageiros com base na bibliografia e, em seguida, validados junto a especialistas dos setores. Posteriormente, construção do modelo e inserção dos dados no ferramenta (software MAMADecisão), objetivando identificar onde estão os pontos frágeis e divergências na qualidade de cada um.

Capítulo 5 - Análise e Discussões. Neste capítulo constam a análise e discussão dos resultados encontrados a partir da aplicação da metodologia desenvolvida no estudo de caso, bem como as conclusões obtidas acerca do desenvolvimento da dissertação, bem como sugestões propostas para trabalhos futuros sobre o tema da pesquisa.

Capítulo 6 - Conclusão. Apresentação do comparativo entre objetivos e resultados da pesquisa, bem como as conclusões e sugestões para futuras pesquisas. 


\begin{tabular}{|l|}
\hline Apresentação \\
Problema \\
Objetivos \\
Justificativa \\
Metodologia \\
\hline
\end{tabular}
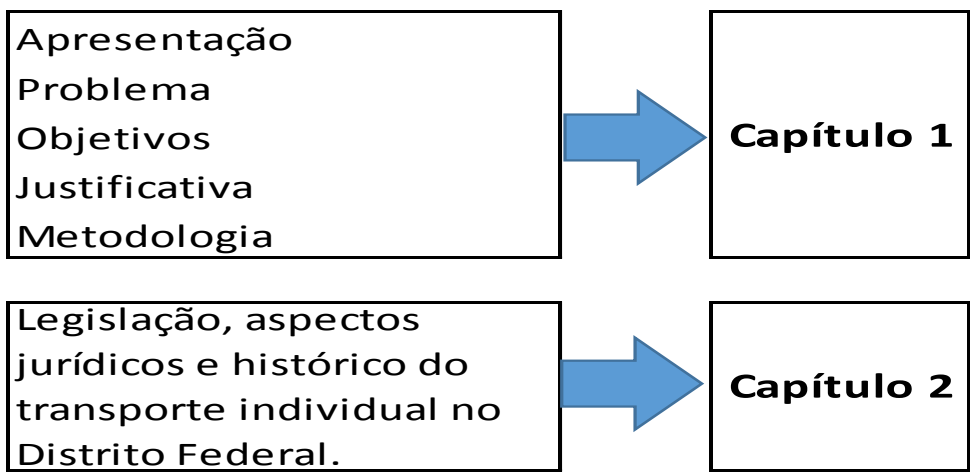

Qualidade e Usabilidade do Serviço de Transporte

\begin{tabular}{|l|l|}
\hline $\begin{array}{l}\text { Construção da árvore de } \\
\text { PVF }\end{array}$ & \\
\hline $\begin{array}{l}\text { Construção dos critérios } \\
\text { de avaliação }\end{array}$ & \\
\hline $\begin{array}{l}\text { Determinação das taxas } \\
\text { de substituição }\end{array}$ & Capítulo 4 \\
\hline $\begin{array}{l}\text { Estabelecimento de níveis } \\
\text { de serviço do modelo }\end{array}$ & \\
\hline
\end{tabular}
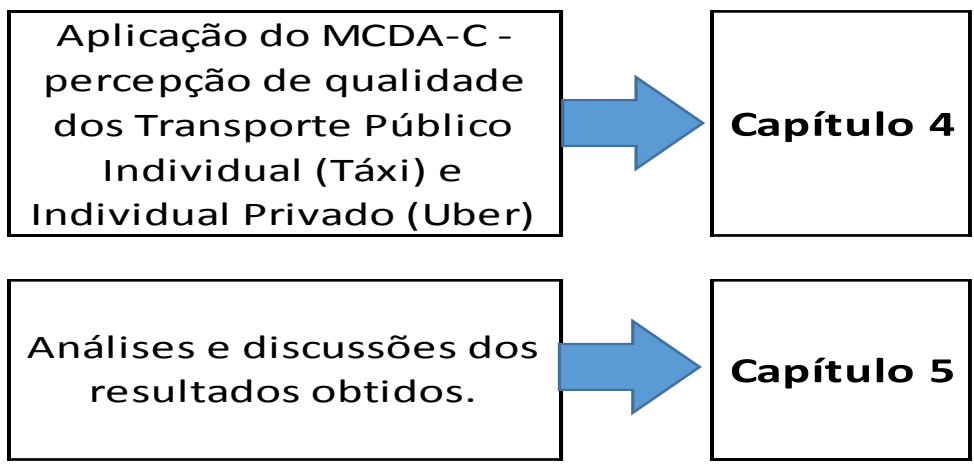

Conclusão e levantamento de sugestões para trabalhos futuros

Figura 1.2 - Estrutura da Dissertação 


\section{HISTÓRICO E CONTEXTUALIZAÇÃO DO TRANSPORTE INDIVIDUAL DE PASSAGEIROS}

Neste capítulo, inicialmente, serão abordados conceitos acerca da origem do que é público e quais os seus limites em relação ao privado. Em seguida apresentaremos o assunto transporte e sua definição, a fim de prosseguirmos na discussão acerca da problemática transporte individual público e privado de passageiros.

Essas definições são necessárias para distinguir as finalidades desses dois tipos de prestação de serviço, bem como entender o porquê da necessidade de aferição da qualidade, de acordo com suas características.

A partir das relações estabelecidas entre o público e o privado serão identificados os parâmetros que permitirão estabelecer os limites de avaliação desse serviço. Para isso foi necessário compreender o histórico da frota de táxi do Distrito Federal, como esse serviço é prestado no âmbito do Distrito Federal, suas características, a origem do serviço prestado por particulares, suas formas de avaliação de qualidade, para, só então, verificar a compatibilidade da qualidade dos dois serviços e os fatores que os tornam preferidos ou preteridos pela população.

Importa salientar que, apesar de existirem diversos estudos acerca do assunto "táxi", a relação entre esse serviço e aquele ofertado por meio de novas tecnologias, por exemplo, o Uber (constitui-se de um aplicativo de smartphone em que o usuário solicita um carro com motorista e define o trajeto a ser realizado), ainda é pouco explorada. Até o momento a literatura não aponta muitos estudos acadêmicos realizados acerca do tema "Uber".

Foi necessário realizar, também, pesquisas acerca da história do Uber, sua atuação, suas características, caracterização das tarifas cobradas e qualidade, para que fosse possível comparar com o serviço de táxi já consolidado na capital federal.

Identificado o contexto dos serviços avaliados, passamos à conceituação do tema "qualidade" e seus desdobramentos em relação aos serviços de transporte, especificamente Táxi e Uber, quanto as práticas de qualidade atualmente adotadas, as medidas de avaliação e, principalmente, a usabilidade. Foram também identificados alguns métodos de avaliação conhecidos e suas aplicações em casos práticos. 


\subsection{A RELAÇÃO DO PÚBLICO E DO PRIVADO NO TRANSPORTE INDIVIDUAL}

A relação público/privado é bastante discutida no âmbito da ciência política. Nessa dicotomia, entende-se que os elementos inseridos em um não podem ser compreendidos noutro. Desta forma, segundo Radbruch (1932), apud Bobbio (2007), consideravam-se os conceitos de direito público e de direito privado como duas categorias do pensamento jurídico, em que há supremacia do primeiro sobre o segundo.

Bobbio (2007) caracteriza o Estado com a relação de subordinação entre os detentores do poder de comando e destinatários do dever de obediência, de forma a distinguir a sociedade política como "relação de desiguais" e a sociedade econômica como "relações entre iguais". Cita, neste aspecto, as fontes do direito: Leis e contratos, respectivamente, como regras de conduta. Nesse contexto surge o conceito de República (do latim, res publica), ou seja, "coisa do povo", entendido o povo como uma sociedade mantida junta.

Adam Smith (1983), apud Moraes (2001), defende a necessidade de desregulamentar e privatizar as atividades econômicas, de forma a reduzir as funções definidas ao Estado e de maneira que este somente delimite parâmetros gerais necessários à execução das atividades dos agentes econômicos. Em suma, o pensamento liberal visa reduzir a presença do soberano político na sociedade, limitando-o estritamente às intervenções na economia.

Essa consequente transformação econômica e social, advinda de uma política liberal e Estado mínimo, retoma a questão da dicotomia entre o público e o privado, de conceituá-los e bem defini-los, devido à necessidade de diferenciá-los sob novas perspectivas em nível de discussões e debates no âmbito social e político contemporâneos.

Conforme Moraes (2001, p.27), o conceito de Neoliberalismo constitui-se de uma ideologia, uma forma específica de ver o mundo social, uma corrente de pensamento que tem incorporado ao conjunto da sociedade a ideia, de certa forma, paradoxal de que o poder público deve ser cada vez menos responsável pela administração daquilo que é público, ou seja, de toda a sociedade. Nesse momento, temos que o transporte individual, antes monopolizado pelo serviço de táxi, tende a ser ocupado também por serviços privados tal qual aquele realizado pelo Uber.

A exploração dessa atividade é regida conforme os princípios da livre iniciativa, da liberdade no exercício de trabalho, da livre concorrência e do livre exercício da atividade econômica, todos previstos na Constituição Federal de 1988. Não se trata de serviço aberto ao público, 
porque é prestado segundo a autonomia da vontade do motorista, o qual pode aceitar ou não a prestação do serviço, conforme sua conveniência. Outrossim, são utilizados veículos particulares, e não veículos de aluguel.

Em relação ao transporte individual no DF, a Lei no 5.323/2014 trata da prestação do serviço público de táxi, porém, não há legislação acerca do tipo de serviço privado prestado pelo Uber, ainda pendente de regulamentação.

\section{2 - TRANSPORTE}

O conceito de transporte é semelhante tanto na literatura nacional quanto internacional. Por exemplo, Ferraz e Torres (2001) definem transporte como a denominação dada ao deslocamento de pessoas e de produtos, ao passo em Manhein (1979) também possui conceito semelhante ao afirmar que o transporte envolve o movimento de pessoas e bens de um lugar para outro.

O movimento das pessoas e coisas é uma das atividades mais antigas da humanidade. A razão para que as pessoas e coisas se movimentem ou sejam movidas de um lugar para outro pode ser explicada por fatores ligados à natureza do comportamento humano em busca do atendimento de necessidades e desejos (Kawamoto e Furtado, 1997).

As finalidades dessa movimentação destacadas por Khisty (1990) são: complementaridade, transferência e a oportunidade de escolha. Essa última será abordada na presente pesquisa, visto que serão tratados dois tipos de serviço de transporte individual oferecidos à população do Distrito Federal.

Complementaridade significa a movimentação de um lugar de origem para um ou mais destinos para satisfazer eventual necessidade. Transferência significa a relação entre tempo, dinheiro e utilização da melhor tecnologia disponível.

De acordo com Ceftru (2006) para haver a atividade de transporte, propriamente dita, são necessários três elementos: um sujeito com a intenção de deslocar um objeto, que pode ser pessoas ou mercadorias; o objeto a ser transportado e o meio responsável por realizar, executar o transporte, mediando o sujeito de transporte com o objeto. Deve ser composto por um conjunto de elementos que constituem um sistema designado de sistema de transporte. 
Segundo Paranhos (2011) o transporte adquire caráter essencial no cotidiano das cidades contemporâneas a ponto de a rede viária urbana e os sistemas de transporte serem comparados às artérias e ao sangue do corpo humano. Nesse sentido, é importante analisar todos os sistemas de transporte, visto que seja qual for o tipo de transporte, fará parte da malha viária de uma cidade e, consequentemente, será importante para a sua constituição como um todo.

Ocorre que dentro dessa temática "transporte", é essencial analisar a infraestrutura viária das cidades, pois ela influencia diretamente na mobilidade e qualidade de vida da população. Vimos que a infraestrutura há muito tempo está sendo voltada para a utilização de veículos particulares. Exemplo disso foi a ocorrência de incentivos à utilização de veículos particulares, com a política de redução de impostos e incentivos fiscais às montadoras de automóveis, em detrimento a políticas de incentivo ao transporte público, ocasionando o aumento da frota de automotivos particulares nas ruas. Noriega e Waisman (2006) ressaltam para o fato dos incentivos para a indústria automobilística terem alavancado a economia brasileira nas últimas décadas.

Para Jacobs (2011) o efeito de "erosão", ou seja, a destruição das cidades "para as pessoas" é proporcional ao aumento da dependência do automóvel em uma sociedade. Porém, não é o que a sociedade capitalista pensa pois, para ela, a utilização do automóvel é a própria reprodução da vida social, de status social, virilidade, maturidade e poder (LUDD, 2004b).

Assim, a utilização do transporte público individual ou, ainda, do transporte individual particular com motorista, retrata, de certa forma, o desapego ao automóvel, ao status social, sem, contudo, deixar de lado o conforto proporcionado pela utilização de um veículo particular para usufruir do transporte porta-a-porta.

Um aspecto positivo desse "desapego" repousa no fato de que o veículo solicitado por meio do serviço de transporte individual raramente transitará pela cidade com apenas uma pessoa (motorista), exceto quando estiver sem passageiro, contribuindo, de certa forma, à redução do tráfego nas vias. Além do mais, o carro não fica parado junto ao seu proprietário, mas continua servindo a outras pessoas, reduzindo também a demanda por estacionamentos.

Porém, segundo Dias (2007) para que haja a integração das políticas locais é necessário discutir sobre a adequação do transporte de táxi como serviço de interesse público ou de atividade econômica aberta à livre iniciativa. Ou seja, apesar de se tratar de um serviço oferecido por 
particulares, deve ser discutida a sua necessidade para a população, ou se a atividade apenas faz parte da economia.

Ocorre que o Estado fiscaliza algumas das atividades exercidas pelo setor privado que, por sua vez, interage e cria procedimentos para que tais atividades sejam exercidas de acordo com limitações e condições estabelecidas (Dias, 2007). Essa é a regulação estatal necessária para o atendimento ao interesse público naquelas atividades em que há titularidade estatal.

\subsection{FROTA DE VEÍCULOS NO DISTRITO FEDERAL}

Segundo Gomide (2011), o deslocamento nos grandes centros urbanos vem se mostrando um problema que afeta diretamente a relação dos habitantes com suas cidades. $\mathrm{O}$ excesso de veículos nas ruas tem ocasionado problemas de circulação em regiões densamente habitadas, devido à ocupação desproporcional do transporte individual motorizado em detrimento do transporte coletivo.

A cada ano temos índices mais próximos de um carro por habitante nas ruas das grandes metrópoles. Reflexo do longo período das medidas de incentivo do governo federal à aquisição de automóveis em condições facilitadas à população, bem como o aumento do poder aquisitivo, por exemplo, com políticas governamentais de aumento real (acima da inflação) do salário mínimo, sem dar a devida atenção aos investimentos do transporte público.

Martins (2015) descreveu a cadeia de reação dos investimentos públicos que priorizam o transporte individual (como o incentivo à compra de veículos, a criação de vagas de estacionamento, entre outros), conforme Relatório Analítico da Pesquisa da Seção de Passageiros (CNT, 2002).

No Distrito Federal, verifica-se, através da divulgação da última estatística de veículos, que em abril de 2016 existiam 1.640.228 veículos dentre automóveis, motocicletas, caminhonete, camionetas e utilitários, para uma população de cerca de 2.914.830 habitantes (IBGE, 2015). Ou seja, são aproximadamente 1,78 habitantes para cada carro (Tabela 2.1).

Tabela 2.1: Proporção de habitantes por veículos no DF

\begin{tabular}{|l|r|}
\hline População & 2.914 .830 \\
Veículos & 1.640 .228 \\
\hline Hab/Veiculo & 1,78 \\
\hline \multicolumn{2}{|l|}{ Fonte: IBGE e DETRAN-DF }
\end{tabular}


Conforme dados divulgados na estimativa de população do IBGE, em agosto de 2014, o Distrito Federal contava, em $1^{\circ}$ de julho de 2014, com aproximadamente 2.852 .372 habitantes, representando um aumento de 2,25\% nos últimos 12 meses, e constituindo a segunda maior taxa de crescimento entre as unidades da federação.

Nesse mesmo período, verificou-se um aumento da frota de veículos automotores do DF na ordem de 5,6\%, ou seja, o crescimento da frota de carros atingiu mais que o dobro do aumento populacional no período de 12 meses (Tabela 2.2).

Tabela 2.2: Variação entre quantidade de veículos existentes no DF entre junho/13 e junho/14

\begin{tabular}{|l|r|r|r|}
\hline Período & jun/13 & jun/14 & Variação (\%) \\
\hline Quantidade de veículos & 1.448 .949 & 1.530 .177 & $5,61 \%$ \\
\hline
\end{tabular}

Fonte: DETRAN-DF

Considerando que a frota de veículos no DF, em $1^{\circ}$ de julho de 2014 , girava em torno de 1.530.177, segundo levantamento do DETRAN, é preocupante pensar que a população do Distrito Federal cresce acima da média nacional e que sua frota de veículos aumenta em níveis mais que duplicados em relação aos habitantes. Caso permaneçam as mesmas taxas de crescimento tanto da população quanto dos automóveis, nos próximos 20 anos haverá mais automóveis do que pessoas na capital federal.

Abaixo (Figura 2.1), segue demonstrativo da evolução da frota de veículos automotores no Distrito Federal no período de 2000 a 2013, contendo o percentual de variação de cada ano.

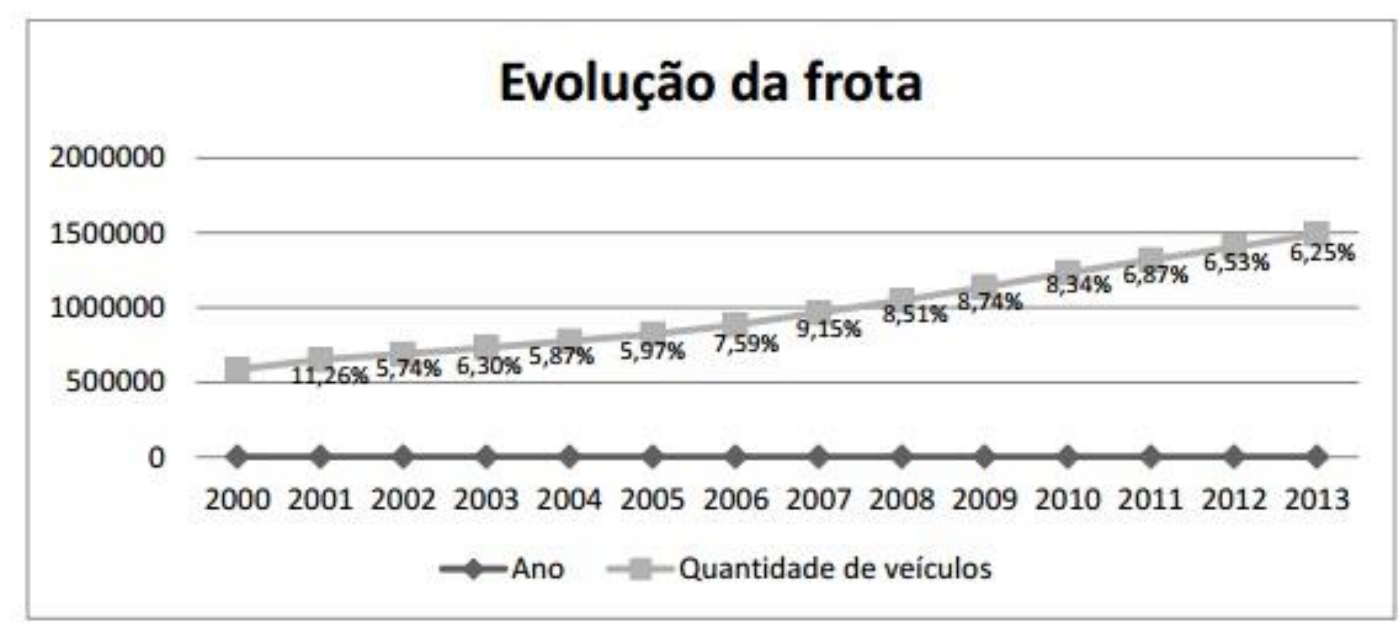

Figura 2.1 - Evolução da frota de veículos no Distrito Federal Fonte: DETRAN-DF 
Gomide (2011) afirma, ainda, que os impactos dessa tradição político-econômica, diretamente relacionados à baixa incidência de medidas efetivas voltadas à mobilidade, vêm sendo verificados em variados aspectos da vida nos centros urbanos, com efeitos desastrosos na economia da cidade como um todo. Situação não diferente da vivida na capital federal.

\section{4 - O SERVIÇO DE TÁXI NO DISTRITO FEDERAL}

O serviço de táxi do Distrito Federal, segundo definição contida na Lei Distrital no 5.323/2014, constitui-se de uma atividade de interesse público consistente no transporte de passageiros e bens em veículo automotor de aluguel, próprio ou de terceiro, a taxímetro ou na modalidade pré-paga, cuja capacidade seja de até 07 (sete) passageiros.

Ressalte-se que, apesar de a lei ter previsto o serviço de táxi pré-pago no DF, este ainda não foi regulamentado pela SEMOB, apesar de já ter encerrado, em 24 de junho de 2015, o processo de consulta pública acerca do projeto de regulamentação.

Para a prestação do referido serviço, é necessário ser taxista autônomo, taxista auxiliar de condutor autônomo, taxista locatário ou pessoa jurídica, desde que autorizados pelo Poder Público e atendidos os requisitos determinados em lei, devendo, ainda, a expedição das autorizações observar a proporção 90\% para autônomos e 10\% para pessoas jurídicas e, dessas, no mínimo $1 \%$ destinado ao serviço de táxi adaptado para atendimento de pessoas com necessidades especiais.

Constata-se no documento "Exposição de Motivos" da supra referida Lei, que dispõe sobre a atividade privativa dos taxistas no Distrito Federal, que o assunto "táxi” encontrava-se, até o ano de 2014, regulamentado de forma precária na capital, gerando lacunas que ocasionavam insegurança jurídica para os que exploram essa atividade.

Apesar de não haver informações precisas, há relatos de que a atividade de táxi no Distrito Federal se iniciou logo após a implantação do aeroporto de Brasília, antes mesmo da inauguração da nova capital federal. Porém, não há indicadores de que havia algum processo sistematizado de escolha dos permissionários do serviço de táxi nesses primeiros anos de existência da "nova" capital federal.

O primeiro relato identificado por meio dessa pesquisa, acerca da existência do serviço de táxi no Distrito Federal, ocorreu em 18 de setembro do ano de 1959, quando a Companhia 
Urbanizadora da Nova Capital do Brasil - NOVACAP, em reunião do seu Conselho de Administração, decidiu adquirir 30 (trinta) carros para a instalação do serviço de táxi em Brasília, pois o transporte público à época era muito deficiente, conforme recortes jornalísticos da época colhidos junto ao acervo do Arquivo Público do Distrito Federal - ArPDF.

Porém, a primeira manifestação oficial acerca do Serviço de Transporte de Táxi ocorreu somente por meio da Portaria $\mathrm{n}^{\mathrm{o}}$ 70, de 27 de abril de 1961, publicada pelo então Prefeito do Distrito Federal no Diário Oficial de 28 de abril de 1961, segundo a qual obrigou os proprietários de táxi a instalarem taxímetros, visando proporcionar vantagem ao público.

Naquele momento os táxis existentes à época deixaram a clandestinidade, pois as corridas eram realizadas por meio de tabelas, confeccionadas pelo Sindicato dos Motoristas, com valores preestabelecidos de acordo com os itinerários a serem executados. (ArPDF)

Verifica-se, nas primeiras publicações oficiais da então Prefeitura do Distrito Federal, que não havia regulamento dispondo sobre a concessão de exploração dos serviços coletivos e individuais de passageiros. As permissões eram concedidas por meio de requerimentos, como observado por meio do Decreto $\mathrm{n}^{\circ} 301$, de 06 de maio de 1964, o qual, em eu art. $1^{\circ}$, suspende temporariamente a exploração desses serviços, ressalvando o direito daqueles que já haviam requerido as concessões. Mais adiante, no art. $2^{\circ}$ do mesmo Decreto, foi estabelecido prazo para a submissão dos taxistas às normas reguladoras das concessões da exploração.

Os serviços de transporte coletivo da capital federal somente passaram a ter um órgão autônomo para controlar a atividade a partir da criação da Secretaria de Serviços Públicos - SSP, prevista na estrutura administrativa da Prefeitura do Distrito Federal, conforme o contido no art. $4^{\circ}$, VIII da Lei Federal $n^{\circ} 4.545$, de 10 de dezembro de 1964. Antes, toda e qualquer publicação referente ao serviço de transporte era realizada diretamente pelo então Prefeito.

Em 02 de fevereiro do ano de 1966 foi lançado o primeiro edital (Edital $n^{\circ}$ 1-66 - DTC) contendo a publicação do deferimento dos primeiros processos de concessão de permissões de táxi de Brasília.

O primeiro dispositivo legal a estabelecer as condições para a outorga das permissões de táxi no Distrito Federal ocorreu por meio do Decreto $n^{\circ}$ 471, de 27 de dezembro de 1965, o qual informou os critérios para requerer a permissão e fixou o limite de outorgas de permissões a 
pessoas físicas ou jurídicas em 900 (novecentos). Essa foi a primeira menção oficial relativa à quantidade de táxis que atenderiam a capital.

Esse mesmo Decreto estabeleceu a preferência àqueles que, em período anterior à sua vigência, já vinham executando o serviço de táxi, desde que devidamente licenciados, concedendo o prazo de 60 (sessenta) dias para requererem sua adaptação às regras. Fato este que reforça a tese de que anteriormente ao Decreto não havia regras bem estabelecidas e oficialmente definidas.

Os aumentos da frota de táxi do Distrito Federal ocorreram somente durante o período de 1965 a 1979, por meio da publicação dos seguintes Decretos (Tabela 2.3):

Tabela 2.3: Demonstrativo dos aumentos da frota de táxi do Distrito Federal.

\begin{tabular}{|c|c|c|c|c|c|}
\hline Legis lação & ano & mês & frota & aumento & $\%$ aumento \\
\hline Decreto $n^{\circ} 471$ & 1965 & dezembro & 900 & - & - \\
\hline Decreto n' 614 & 1967 & maio & 1.050 & 150 & $16,67 \%$ \\
\hline Decreto $n^{\circ} 673$ & 1967 & novembro & 1.600 & 550 & $52,38 \%$ \\
\hline Decreto $\mathrm{n}^{\circ} 792$ & 1968 & agosto & 1.700 & 100 & $6,25 \%$ \\
\hline Decreto $n^{\circ} 1376$ & 1970 & junho & 2.000 & 300 & $17,65 \%$ \\
\hline Decreto no 2064 & 1972 & setembro & 2.100 & 100 & $5,00 \%$ \\
\hline Decreto $n^{\circ} 2301$ & 1973 & junho & 2.500 & 400 & $19,05 \%$ \\
\hline Decreto $n^{\circ} 2342$ & 1973 & agosto & 2.700 & 200 & $8,00 \%$ \\
\hline Decreto $n^{\circ} 2527$ & 1974 & janeiro & 3.000 & 300 & $11,11 \%$ \\
\hline Decreto $n^{\circ} 3905$ & 1977 & outubro & 3.300 & 300 & $10,00 \%$ \\
\hline Decreto $n^{\circ} 4596$ & 1979 & março & 3.400 & 100 & $3,03 \%$ \\
\hline
\end{tabular}

Fonte: Diário Oficial do Distrito Federal, disponível em:

http://www.sinj.df.gov.br/sinj/Pesquisas.aspx

Em pesquisa realizada em toda a legislação que trata do serviço de táxi no Distrito Federal foi verificado que o último aumento da frota ocorreu no ano de 1979, por meio do Decreto $\mathrm{n}^{\circ} 4.596$, de 13 de março de 1979, segundo o qual elevou o quantitativo máximo permitido para 3.400 (três mil e quatrocentos).

Segundo o Censo IBGE realizado no ano de 1980, a população do Distrito Federal perfazia o total de 1.203.333 (um milhão duzentos e três mil trezentos e trinta e três) pessoas. Significa dizer que havia 01 (um) táxi para cerca de 354 (trezentas e cinquenta e quatro) pessoas.

De acordo com estimativa do IBGE para o ano de 2015, a população do DF era de 2.914.830 dois milhões novecentos e quatorze mil oitocentos e trinta) pessoas, reduzindo, portanto, a proporção para 01 (um) táxi para cerca de 857 (oitocentos e cinquenta e sete) pessoas (Tabela 2.4). 
Tabela 2.4: Quantidade de pessoas por táxi no Distrito Federal

\begin{tabular}{|c|c|c|c|}
\hline Ano & População & Frota & $\begin{array}{c}\text { Relação pessoas } \\
\text { por táxi }\end{array}$ \\
\hline 1980 & 1.203 .333 & 3.400 & 354 \\
\hline 2015 & 2.914 .830 & 3.400 & 857 \\
\hline
\end{tabular}

Fonte: Diário Oficial do Distrito Federal e IBGE

Após o aumento ocorrido em 1979, há 37 anos, não houve mais nenhum acréscimo da frota de táxi no Distrito Federal, apesar de a população ter crescido em torno de $142 \%$ nesse intervalo de tempo (Tabela 2.5).

Tabela 2.5: Aumento da população entre os anos de 1980 e 2015.

\begin{tabular}{|c|c|c|}
\hline Ano & População & $\begin{array}{c}\text { Aumento \% em } \\
\text { relação a 1980 }\end{array}$ \\
\hline 1980 & 1.203 .333 & - \\
\hline 2010 & 2.570 .160 & $114 \%$ \\
\hline 2015 & 2.914 .830 & $142 \%$ \\
\hline
\end{tabular}

Fonte: IBGE

Para melhor comparação entre as frotas de outras capitais, pode ser realizado o cálculo da frota de táxi para cada 100 mil habitantes, conforme levantamento realizado por Dias (2007). Assim, à época do último aumento, a frota era de 283 táxis para cada 100.000 habitantes. Hoje, essa proporção reduziu para apenas 117 , devido à manutenção do número absoluto de táxi e aumento da população (Tabela 2.6).

Tabela 2.6: Frota de táxi para cada 100 mil habitantes

\begin{tabular}{|c|c|c|c|}
\hline Ano & População & Frota & $\begin{array}{c}\text { Frota de táxis (por } \\
100 \text { mil habitantes) }\end{array}$ \\
\hline 1980 & 1.203 .333 & 3.400 & 283 \\
\hline 2015 & 2.914 .830 & 3.400 & 117 \\
\hline
\end{tabular}

Fonte: Diário Oficial do Distrito Federal e IBGE

Para que a frota de táxi mantivesse a mesma proporção existente na época do último acréscimo ocorrido no ano de 1979, seriam necessários, atualmente, em torno de 8.250 para atender todo o território da capital federal. 
A partir dessa medida, é possível comparar com o estudo realizado por Dias (2007) relacionado ao tamanho das frotas existentes em diversas capitais brasileiras. Realizando um corte somente com as 10 (dez) capitais mais populosas, o estudo apontou o seguinte (Tabela 2.7):

Tabela 2.7: Frota de táxi nas 10 capitais mais populosas do Brasil.

\begin{tabular}{|l|r|c|}
\hline \multicolumn{1}{|c|}{ Cidade } & $\begin{array}{c}\text { População es timada } \\
\text { e m 2007 }\end{array}$ & $\begin{array}{c}\text { Frota (táxis por 100 } \\
\text { mil habitantes ) }\end{array}$ \\
\hline São Paulo & 10.886 .518 & 327 \\
\hline Rio de Janeiro & 6.093 .472 & 312 \\
\hline Salvador & 2.892 .625 & 258 \\
Brasília & 2.455 .903 & 137 \\
Fortaleza & 2.431 .415 & 168 \\
Belo Horizonte & 2.412 .937 & 250 \\
Curitiba & 1.797 .408 & 690 \\
Manaus & 1.646 .602 & 230 \\
Recife & 1.533 .580 & 409 \\
Porto Alegre & 1.420 .667 & 285 \\
\hline \multicolumn{2}{|c|}{} \\
* Fonte: DIAS, 2007 (com modificações); Contagem da População IBGE, 2007
\end{tabular}

Ou seja, já naquela época a capital federal possuía a menor relação entre frota de táxi e habitantes, dentre as capitais brasileiras mais populosas, com apenas 137 táxis para cada 100 mil habitantes, sendo que sua frota encontra-se desatualizada desde o ano de 1979 até os dias atuais.

Essa situação, de carência de táxis, prejudica o deslocamento dos potenciais usuários desse serviço, ocasionando um desequilíbrio entre a oferta e a demanda e, por consequência, elevando o preço do serviço. Incentiva, também, esses potenciais usuários a utilizarem seus próprios veículos para obterem a facilidade e o conforto almejados.

\subsubsection{A SEGURANÇA JURÍDICA PROPORCIONADA PELA SUBSTITUIÇÃO DAS PERMISSÕES POR AUTORIZAÇÕES NO DISTRITO FEDERAL}

Até a publicação da Lei $n^{0} 5.323 / 2014$ os taxistas do Distrito Federal prestavam serviço por meio de outorgas na modalidade de permissão, sem possuírem a segurança jurídica necessária para exercerem sua atividade laboral, conforme descrito no documento "Exposição de Motivos" da referida Lei. Com a publicação dessa Lei, foram estabelecidos alguns critérios para darem segurança jurídica aos taxistas, tais como a substituição das antigas permissões por autorizações. 
Conforme definição contida no art. $2^{\circ}$, IV da Lei no 8.987/95 (Lei de Concessões e Permissões), a permissão de serviço público se constitui na delegação, a título precário, mediante licitação, da prestação de serviços públicos, feita pelo poder concedente à pessoa física ou jurídica que demonstre capacidade para seu desempenho, por sua conta e risco.

A autorização para prestar o serviço de táxi é um ato administrativo, discricionário e precário e se constitui na transferência ao particular, de serviço público de fácil execução, sendo remunerado através de tarifas.

Segundo Meirelles (2009) a autorização é um ato administrativo discricionário unilateral e precário, pelo qual o Poder Público torna possível ao pretendente a realização de certa atividade, serviço ou utilização de determinados bens particulares ou públicos, de seu exclusivo ou predominante interesse, que a lei condiciona à aquiescência prévia da Administração. Já em relação à permissão, Meirelles (2009) ensina que se constitui de um ato negocial, unilateral, discricionário e precário através do qual a Administração faculta ao particular a utilização individual de determinado bem público, desde que haja interesse da coletividade.

Assim, a diferença essencial entre os institutos da permissão e da autorização é que o primeiro é um ato unilateral do Poder Púbico e possui característica personalíssima, não sendo passível de transferência a outra pessoa. Essa insegurança jurídica já advinha do Decreto $n^{\circ} 471$, de 27 de dezembro de 1965, o qual, naquela época já determinava, em seu art. $8^{\circ}$, que a transmissão da permissão dependia de expressa autorização da autoridade permitente. Já na autorização, por tratar-se de ato negocial entre o taxista e a Administração Pública, já permite a hipótese de transferência a terceiros.

Porém, com o advento da Lei de Mobilidade Urbana foi possível, pela primeira vez, garantir a transferência do direito de exploração de serviços de táxi aos herdeiros, no caso de falecimento do outorgado.

Apesar da possibilidade de transferência garantida pela Lei $n^{\circ} 12.587 / 2012$, Di Pietro (2006) considera que a transferência de concessão prevista no art. 27 da Lei de Concessões e Permissões sem licitação constitui em burla ao art. 175 da Constituição Federal. Vejamos:

Art. 175. Incumbe ao Poder Público, na forma da lei, diretamente ou sob regime de concessão ou permissão, sempre através de licitação, a prestação de serviços públicos. 
Nesse sentido, a Lei 12.865/2013, veio permitir a transferência das outorgas a qualquer interessado, desde que satisfaça os requisitos exigidos pelo poder público local, bem como a transferência em caso de falecimento do outorgado titular a seus sucessores legítimos, na forma do Código Civil. Ambos os casos sujeitos à prévia anuência do poder público e satisfação dos requisitos fixados para a outorga.

\subsection{ORIGEM DO SERVIÇO PRESTADO PELA UBER}

De acordo com Uber Brasil (2016), a empresa Uber iniciou suas atividades em 2009, com o propósito inicial de fornecimento de serviço de táxi de luxo, com carros de altíssimo nível, na cidade de São Francisco, Califórnia - EUA. Porém, a Uber Technologies Inc. foi fundada oficialmente em junho de 2010, e hoje atua em mais de 476 cidades e em mais de 70 países, sendo que no Brasil, até a data desta pesquisa, prestava seus serviços em onze cidades: São Paulo, Rio de Janeiro, Belo Horizonte, Brasília, Porto Alegre, Goiânia, Recife, Curitiba, Salvador, Campinas e Fortaleza.

A primeira ideia para a sua criação ocorreu na cidade de Paris, quando seus criadores, Travis Kalanick e Garret Camp, tiveram dificuldade em pegarem táxi, ou transporte público ou até mesmo um motorista particular para retornarem ao hotel. Então pensaram em desenvolver algo que estivesse às suas mãos e, com um simples toque na tela do celular, fosse possível chamar um carro com motorista particular, para que potenciais clientes se deslocassem de forma confortável e segura (Uber Brasil, 2016).

O objetivo da criação do aplicativo era o de facilitar e inovar a forma pela qual as pessoas se locomoviam pelas cidades, sendo um dos pioneiros em E-hailing, que consiste na solicitação de algum meio de transporte via plataforma virtual, computador ou dispositivo móvel. Seu primeiro objetivo era o fornecimento de serviço de taxi de luxo e o primeiro produto da empresa foi o UberBlack.

Originalmente, a palavra Uber surgiu da língua alemã "über”, que, segundo o dicionário online Michaelis, significa dizer "sobre", “acima de", "além", "mais de”. O significado dessa mesma palavra na língua inglesa, segundo definição do dicionário online Cambridge, quer dizer "algo extremo", ou "extremamente bom" ou ainda "algo bem sucedido". Em consulta ao dicionário online Collins, "uber" significa dizer que se trata do "melhor" ou do "melhor exemplo". 
A intenção dos criadores, ao nomear o aplicativo, era de defini-lo como algo superior ao serviço de táxi já existente, um serviço com melhor qualidade, tanto que o primeiro nome utilizado foi UberCab, onde uber significa "superior" ou "super" e cab significa táxi, de acordo com a língua inglesa. Posteriormente, houve a retirada do sufixo e permaneceu apenas Uber como nome do aplicativo e da empresa.

Trata-se de uma empresa de tecnologia que oferece serviços de transporte privado, semelhante ao táxi convencional, através de um aplicativo de smartphone o qual conecta passageiros e motoristas. O aplicativo informa, por meio do Sistema de Posicionamento Global, aos motoristas registrados no sistema o local exato onde o passageiro se encontra.

Diferentemente dos táxis, que são classificados como serviço de transporte público individual, aquele oferecido pela Uber tem natureza privada, visto que não há a necessidade de serem autorizados pelo Poder Público. Fato este que, justamente, tem gerado conflito em várias cidades em que se estabelece.

Conhecido no mundo todo mais popularmente como sistema de carona remunerada, a Uber não possui frota própria nem motoristas próprios. Tratam-se de pessoas que trabalham de modo particular, desde que satisfaçam os requisitos de qualidade e segurança exigidos pela empresa, podem prestar serviço em nome desta e por meio de seu aplicativo. Todos os pagamentos são realizados por meio eletrônico e desconto direto na fatura do cartão de crédito, não havendo contato com dinheiro em espécie entre passageiro e motorista nem há a necessidade de utilização de máquina de cartão de crédito no interior do veículo.

\subsubsection{O SERVIÇO UBER PRESTADO NO DISTRITO FEDERAL E SUAS IMPLICAÇÕES}

O serviço prestado por meio do aplicativo da Uber teve início na cidade de Brasília em 15 de novembro de 2014, tendo seu lançamento oficial ocorrido somente em 26 de fevereiro de 2015.

Após o início de suas atividades em Brasília, surgiram diversas manifestações e protestos de taxistas contra a sua permanência na cidade, dando início à movimentações visando a proibição dos seus serviços na capital federal.

Esses movimentos contrários à sua permanência deram origem ao Projeto de Lei ${ }^{\circ}$ 282/2015, apresentado na Câmara Legislativa do Distrito Federal - CLDF em 17 de março de 2015, o qual proibia o uso de aplicativos por veículos e motoristas não cadastrados junto ao Poder Público, além de outras restrições ao tipo de transporte. 
Porém, apesar de aprovado na CLDF e encaminhado, em 16 de julho de 2015, ao Governador do Distrito Federal para sanção, este, na data de 06 de agosto de 2015, vetou em sua totalidade o texto do Projeto de Lei, com a justificativa de que a matéria seria de iniciativa do Chefe do Poder Executivo.

Logo após, em 18 de novembro de 2015, foi apresentado novo Projeto de Lei $\mathrm{n}^{\circ}$ 777/2015, dessa vez proposto pelo Governador do DF, em que este definiu o transporte realizado pela Uber como Sistema de Transporte Individual Privado - STIP, portanto, diferenciando daquele realizado por táxi. Inclusive, conforme a Exposição de Motivos apresentada, há expressa diferenciação entre os dois serviços.

Atualmente a Uber atua no centro de Brasília e região metropolitana, conforme pode ser visto na Figura 2.2.

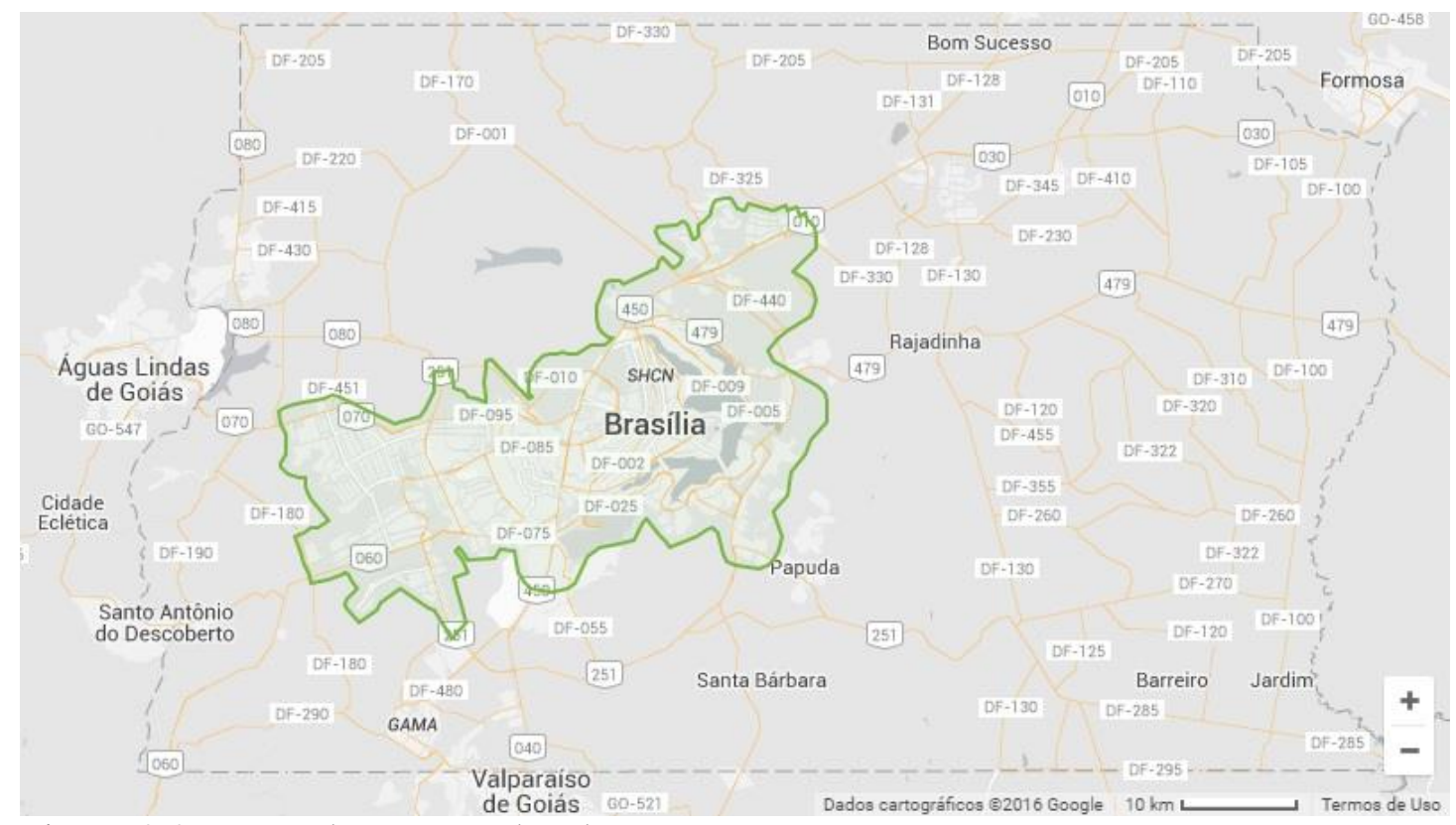

Figura 2.2: Mapa de atuação da Uber

Fonte: https://www.uber.com/pt/cities/brasilia/

Apesar de existirem diversas categorias de prestação de serviço por meio do aplicativo da Uber, em Brasília só estão disponíveis 02 (duas): UberBlack e UberX. A primeira consiste na disponibilização de carros tipo sedãs médios, sempre na cor preta, com vidros fumê, todos com banco de couro e ar condicionado e com idade máxima de 03 (três) anos. A segunda categoria abarca modelos mais simples, como compactos ou sedãs pequenos, nas cores prata, cinza ou preto, e com preço mais competitivo. 


\subsection{DIFERENÇAS TARIFÁRIAS DOS SERVIÇOS DE TÁXI E UBER}

Recentemente, em 17 de março de 2016, o governador do DF publicou o Decreto $\mathrm{n}^{\mathrm{o}} 37.189$, que reajustou as tarifas de táxi da seguinte forma (Tabela 2.8):

Tabela 2.8: Tarifas do serviço de táxi do DF

\begin{tabular}{|l|rr|}
\hline \multicolumn{3}{|c|}{ Tabela de tarifas - TÁXI } \\
\hline bandeirada & $\mathrm{R} \$$ & 5,240 \\
km percorrido em bandeira 1 & $\mathrm{R} \$$ & 2,850 \\
km percorrido em bandeira 2 & $\mathrm{R} \$$ & 3,660 \\
\hline Hora parada & $\mathrm{R} \$$ & 31,720 \\
\hline Incremento 100m - bandeira 1 & $\mathrm{R} \$$ & 0,285 \\
\hline Incremento 78,72m - bandeira 2 & $\mathrm{R} \$$ & 0,285 \\
Incremento 31,66s parado & $\mathrm{R} \$$ & 0,285 \\
\hline
\end{tabular}

Fonte: Decreto Distrital n ${ }^{\circ} 37.189 / 2016$.

As tarifas aplicadas aos serviços da Uber, disponíveis em seu sítio eletrônico, na capital federal, estão descritas nas Tabelas 2.9 e 2.10 abaixo:

Tabela 2.9: Tabela de tarifas do serviço UberBlack

\begin{tabular}{|l|ll|}
\hline \multicolumn{3}{|c|}{ Tabela de tarifas - UBERBLACK } \\
\hline preço base ou bandeirada & $\mathrm{R} \$$ & 4,00 \\
incremento por minuto & $\mathrm{R} \$$ & 0,32 \\
incremento por km & $\mathrm{R} \$$ & 2,20 \\
Preço mínimo & $\mathrm{R} \$$ & 7,00 \\
Taxa de cancelamento & $\mathrm{R} \$$ & 7,00 \\
\hline
\end{tabular}

Fonte: Uber.

Tabela 2.10: Tabela de tarifas do serviço UberX

\begin{tabular}{|l|cc|}
\hline \multicolumn{3}{|c|}{ Tabela de tarifas - UBERX } \\
\hline preço base ou bandeirada & $\mathrm{R} \$$ & 2,70 \\
incremento por minuto & $\mathrm{R} \$$ & 0,18 \\
incremento por km & $\mathrm{R} \$$ & 1,25 \\
Preço mínimo & $\mathrm{R} \$$ & 6,00 \\
Taxa de cancelamento & $\mathrm{R} \$$ & 6,00 \\
\hline
\end{tabular}

Fonte: Uber.

Somente a partir desses dados, acerca das tarifas aplicadas, já é possível identificar a vantagem financeira ao passageiro na utilização do Uber ao invés do serviço de táxi convencional, pois o preço inicial e o preço por quilômetro percorrido são inferiores em ambos os tipos de serviço oferecidos pela primeira. 
Em relação aos preços praticados pelos dois serviços, de acordo com a teoria do consumo, apontada por Kawamoto e Furtado (1997) quanto maior for o preço de um determinado bem ou serviço em um mercado, em geral a quantidade consumida tende a diminuir. Esse efeito tem sido percebido no serviço de táxi do DF, visto que o serviço ofertado pela Uber tem sido, em geral, mais vantajoso financeiramente aos usuários do sistema.

Ademais, tem-se discutido muito nas redes sociais e jornais de grande circulação acerca da qualidade do serviço ofertado no sistema Uber de transporte, segundo o qual os motoristas têm tratado os passageiros com a hospitalidade e cordialidade inexistentes no serviço de táxi. É justamente essa cordialidade que será avaliada na presente pesquisa, a fim de verificar o grau de satisfação do usuário na prestação do serviço de transporte individual.

\subsection{SISTEMA DE AVALIAÇÃO ATUAL DOS SERVIÇOS DE TÁXI E UBER}

\subsubsection{AVALIAÇÃO DO SERVIÇO DE TÁXI}

Cabe afirmar que até o ano de 2016 não existe um sistema próprio governamental que avalie especificamente a atuação dos motoristas de táxi. Em geral, as manifestações acerca do Sistema de Transporte Público Individual - STPI são registradas por meio da Ouvidoria Geral do Distrito Federal, através do site eletrônico ou por meio telefônico ou ainda por meio de registro presencial.

Em relação aos táxis pertencentes a empresas (Pessoas Jurídicas) ou Cooperativas, esses, além do sistema convencional disponibilizado pelo governo para avaliação do serviço, também são passíveis de avaliação por meio de contato direto através dos canais de comunicação disponibilizados por elas (central rádio táxi ou website).

Segundo consta no site da Ouvidoria Geral, o cidadão pode registrar reclamações, denúncias elogios e sugestões e, ao registrar sua manifestação, recebe um protocolo de acompanhamento. Ocorre que eventuais elogios acerca de bons atendimentos prestados por taxistas acabam não sendo registrados, visto que não há o incentivo à essa manifestação por parte do usuário, restando registrar apenas os problemas encontrados.

Há a previsão legal, por meio da Lei Distrital nº 5.323/2014, de fiscalização dos serviços de táxi, porém, não há nenhuma regulamentação que estabelece critérios de qualidade a serem aferidos pelos próprios clientes. 
Atualmente a fiscalização do serviço de táxi está a cargo dos auditores-fiscais de atividades urbanas, especialidade transportes, conforme definido no art. 48 da Lei $n^{\circ}$ 5.323/2014, cujo órgão ao qual estão vinculados é a Subsecretaria de Fiscalização, Auditoria e Controle SUFISA, por sua vez pertencente à estrutura orgânica da Secretaria de Estado de Mobilidade do Distrito Federal - SEMOB/DF.

As atividades de fiscalização do sistema de transporte do DF, inclusive do serviço de táxi, estão respaldadas no art. 112, VIII do Decreto n ${ }^{\circ} 35.748 / 2014$.

Ressalte-se que eventuais apurações de qualidade pelos clientes seriam muito importantes para ajuda e melhoria do serviço de táxi prestado, visto que eles constituem o público-alvo do serviço e, por isso, seriam os mais bem capacitados para avaliarem.

\subsubsection{AVALIAÇÃO DO SERVIÇO UBER}

O Uber possui um sistema próprio de avaliação a partir da experiência do cliente/passageiro. Esse sistema consiste em, após realizada a viagem, o aplicativo finaliza a viagem e sugere ao passageiro que o avalie, de forma anônima, a performance do motorista e a qualidade do serviço prestado, atribuindo notas numa escala de 1 a 5, podendo, ainda, deixar comentários acerca da experiência.

Essa avaliação, juntamente com o comentário, é analisada e considerada pelos administradores do sistema, não sendo compartilhada com o motorista o seu resultado e, os motoristas que não mantiverem a nota média mínima aceitável, de 4,6 (quatro vírgula seis), são desconectados do aplicativo, não podendo mais realizar viagens por meio dele. Outra forma de avaliar o serviço prestado é através de resposta ao e-mail recebido logo após a viagem ter sido finalizada.

Pode ser considerado também um item de qualidade do serviço prestado pelo Uber, a ser avaliado pelo cliente, a possibilidade de ser transportado sem a necessidade de desembolsar o dinheiro no ato, pois o número do cartão de crédito já está previamente cadastrado no aplicativo, bastando apenas solicitá-lo que o débito será feito diretamente em sua fatura. Porém, este é apenas um quesito que será ainda avaliado na presente pesquisa, a fim de verificar se constitui mesmo um indicador de qualidade para o cliente.

Outro item possível de aferição de qualidade é o fato de haver uma central de relacionamento com o cliente, de fácil atendimento (por meio do próprio aplicativo), onde é possível fazer reclamações. 


\section{QUALIDADE NO SERVIÇO DE TRANSPORTE}

A ideia de qualidade foi discutida primeiramente pelos filósofos gregos, que pensaram no ideal da excelência (Maximiano, 2008). Excelência, por sua vez, é a característica que define superioridade em relação ao semelhante, ou seja, constitui-se em "fazer o melhor". A preocupação com o bom e belo, as normas éticas, a hospitalidade e outros princípios de conduta são fundamentos da ideia da qualidade como o melhor que se pode fazer.

O conceito de qualidade é amplo e envolve muitos aspectos simultaneamente, porém, apesar de envolver diversos itens em sua definição, a abordagem básica para defini-la seria dar ênfase às necessidades, aos desejos, às expectativas e às preferências do consumidor (Paladini, 2005).

Crosby (1990) entende que a qualidade pode ser a satisfação de qualquer necessidade ou desejo de um cliente ou usuário. E Crosby (1985) define qualidade como o atendimento aos requisitos pré-estabelecidos, ou seja, é a entrega do que está sendo pretendido.

Moller (2001) ressalta que é o cliente que determina qual deve ser o padrão de qualidade dos produtos e serviços. A qualidade dos serviços deve considerar tanto as expectativas quanto às necessidades dos clientes (Gianesi e Corrêa, 1995). Assim, a empresa ou prestador de serviço deve assegurar que seus produtos ou serviços estejam adequados aos padrões aceitos. Trata-se, na verdade, de inspirar as pessoas para que façam o melhor possível, a fim de ganharem clientela e, mais importante, não perderem a que já possuem.

Acerca da qualidade do transporte, Ramos (2013) afirma que o primeiro passo a favor da busca por melhores serviços consiste no estabelecimento de indicadores que reflitam os vários aspectos da qualidade desejada pelo usuário. Ainda segundo esse autor, o emprego de indicadores é o ponto central, fundamental para que a qualidade de um Sistema de Transporte Público de Passageiros - STPP seja adequadamente medida.

Nesse sentido, em virtude da concorrência cada vez mais acirrada entre o serviço de táxi e o aplicativo Uber na busca de clientes, o quesito "qualidade" se tornou essencial para a escolha do serviço a ser utilizado pelo potencial passageiro. A qualidade do serviço está assegurada quando satisfaz ou excede às expectativas do cliente (Moller, 2001).

Silva (2005), apud Ramos (2013), cita que estão relacionadas com a qualidade, a percepção, as expectativas e as necessidades do cliente, sendo esses fatores determinantes para a melhoria da qualidade dos serviços prestados. 


\subsection{PRÁTICAS DE QUALIDADE IDENTIFICADAS SOBRE SERVIÇO DE TÁXI E UBER}

Drucker (1989), apud Simionatto (2006), afirma que o propósito de todo negócio é criar clientes. Ou seja, no caso do transporte individual privado de passageiros realizado por meio da Uber, o cliente deve ser valorizado, posto que se trata de uma das regras de mercado para se manter competitivo.

Ao mesmo tempo em que é possível observar a busca pela excelência no atendimento aos clientes do transporte individual privado de passageiros (Uber), existe uma legislação falha e que não prevê melhorias nem índices de aferição de qualidade para o serviço público de passageiros outorgado aos taxistas.

Paladini (2005) afirma que o termo qualidade é dinâmico e que sofre um processo evolutivo ao longo do tempo. Essas alterações são devidas às mudanças nas posturas, necessidades, gostos, preferências e expectativas dos consumidores. Fleury, Wanke e Figueiredo (2000), afirmam que todo o resultado do esforço logístico se traduz no serviço ao próprio cliente. Para ser competitiva, uma empresa deve adequar seus produtos aos clientes e não seus clientes aos produtos (Simionatto, 2006).

Acerca da superação das expectativas do cliente, o assunto hospitalidade tem sido cada vez mais estudado no ramo da logística, vista a necessidade de satisfazer e agregar valor ao serviço oferecido ao cliente. Segundo Brotherton (1999), a hospitalidade consiste na troca humana contemporânea, assumida voluntariamente e concebida para aumentar o bem-estar mútuo das partes envolvidas mediante oferta de acomodação e/ou alimento e/ou bebida.

Nesse sentido, é possível identificar pelo menos uma característica da hospitalidade no serviço prestado pela Uber, por exemplo, quando seus motoristas oferecem água e guloseimas. Essa regra da empresa caracteriza a necessária hospitalidade para com seus clientes, a fim de fidelizálos e, consequentemente, buscar maior lucratividade por meio de sua satisfação, fato este não observado por grande maioria dos taxistas.

Heskett e Schlesinger (1994), apud Amorim et al. (2004), afirmam a existência de uma cadeia de serviço-lucro onde estão inclusos a satisfação, a fidelidade do cliente e os resultados financeiros da empresa.

Tidd e Bessant (2008) explicam que a inovação é capaz de agregar valor aos serviços e produtos de uma determinada empresa, diferenciando-a ou reposicionando-a em um mercado 
competitivo. A inovação é ainda mais relevante em mercados de alta competitividade, principalmente quando os produtos concorrentes são praticamente equivalentes.

A busca por inovação, pela Uber, ocorre devido à sua competição com o serviço público, para o qual a lei prevê a simples necessidade da prestação do serviço de transporte, ou seja, de prestar "hospedagem", não obrigando, necessariamente, os taxistas a proverem a "hospitalidade" a seus clientes.

Ao determinar a prestação de serviço adequado, a Lei de Concessões e Permissões não se preocupou com a competitividade do serviço, ocasião bastante relevante para a iniciativa privada e que, inclusive, pode determinar a sobrevivência de uma empresa.

Segundo a pesquisadora Telfer (1996) a hospitalidade pode ser definida como o desejo por companhia, ou prazeres do acolhimento, a vontade de ser agradável aos outros e o desejo de satisfazer o desejo do outro. Este conceito pode ser plenamente adaptado ao serviço de transporte de passageiros, de forma que eles não se sintam apenas "hóspedes" no veículo, mas possam se sentir à vontade e bem-vindos.

O serviço tradicional de táxi, antes do surgimento da competição do Uber, encontrava-se estabilizado e possuía clientela fixa, em que o eventual mau atendimento ou má prestação do serviço não importava, necessariamente, em perda de clientes para o sistema como um todo. Era possível que apenas houvesse a troca do motorista pelo usuário, na tentativa de encontrar um atendimento melhor, mas o cliente continuaria a usufruir do sistema táxi de transporte.

Essa estagnação do serviço de táxi e perda de mercado para o Uber é explicada por Keller e Kotler (2006), ao conceituarem maturidade do produto como o período de baixa no crescimento das vendas devido ao alcance da aceitação da maioria dos compradores potenciais, e declínio quando o produto atinge sua obsolescência e é substituído pelo concorrente mais inovador.

Keller e Kotler (2006) afirmam, ainda, que o sucesso da marca pode ser afetado por mudanças na preferência dos consumidores, mudanças tecnológicas, de mercado ou de marketing. $\mathrm{Ou}$ seja, a novidade tecnológica proporcionada pelo Uber gerou a perda do, já estagnado, mercado do táxi.

A unidade de medida passível de aferição para o serviço de táxi, constatada a sua maturidade, era a eficácia em relação ao objetivo proposto, ou seja, o simples transporte do passageiro ao seu destino, ou, ainda, a simples finalidade. Outros quesitos, como qualidade e eficiência, já 
não eram percebidos e, por isso, houve a oportunidade de crescimento do serviço de transporte Uber no mercado.

Segundo Maximiano (2008) eficácia é a palavra usada para indicar a simples realização dos objetivos, e eficiência significa indicar que uma organização utiliza produtivamente, de maneira econômica ou da forma correta, seus recursos.

Trazendo para o campo da prestação de serviço de transporte, eficácia significa simplesmente cumprir com a finalidade de transportar o passageiro ao seu destino, ao passo em que eficiência significa transportá-lo da forma mais adequada possível. Assim, para atingir a satisfação do cliente, é importante que a qualidade seja agregada, com vistas a manter o grau de satisfação e, talvez, superar as expectativas, garantindo a fidelização do cliente.

Em relação à eficiência, podemos utilizar o conceito aplicado à Administração Pública, previsto no caput do art. 37 da Constituição Federal. O objetivo desse princípio é assegurar que os serviços públicos sejam prestados com adequação às necessidades da sociedade que os custeia (Alexandrino, 2009).

A eficiência integra o conceito legal de serviço púbico adequado, previsto na Lei no 8.987/1995 (Alexandrino, 2009). Porém, a falta de prestação do serviço de transporte público com a eficiência esperada, aliada à inserção da opção do transporte privado com as mesmas características no mercado, sob o aspecto da mobilidade, tende à migração desses usuários para o serviço que apresente a melhor qualidade.

\subsection{MEDIDAS DE AVALIAÇÃO DA QUALIDADE}

Apesar de intangível, Crosby (1985) afirma que é um erro achar que a qualidade não é mensurável. Existe a possibilidade de avaliação do processo de entrega em si, e não apenas da efetividade da entrega de um produto. Lima Jr. (1995) elenca a possibilidade de avaliação do serviço durante a sua execução.

Segundo Santos (2014), as aferições de qualidade no serviço de transporte podem ser divididas em duas categorias: a) autores que realizaram pesquisas diretamente com usuários de transporte público para avaliação do serviço; e b) aferições de qualidade através de comparações com indicadores do nível de serviço pré-definidos. Para a coleta de dados e avaliação, serão utilizadas as duas categorias. 
Rodrigues (2008) realizou o levantamento acerca dos principais indicadores de avaliação de qualidade em transporte coletivo urbano, de acordo com os seguintes autores (Quadro 3.1):

Quadro 3.1: Medidas de avaliação de qualidade em transporte coletivo urbano

\begin{tabular}{|c|l|}
\hline Autor (es) & \multicolumn{1}{|c|}{ Indicadores } \\
\hline $\begin{array}{c}\text { Waisman (1983 } \\
\text { apud Rodrigues, } \\
\text { 2006) }\end{array}$ & $\begin{array}{l}\text { Comparabilidade, cobertura, resposta à necessidade, compreensibilidade, } \\
\text { flexibilidade, incentivos para o alcance de melhorias e disponibilidade de dados }\end{array}$ \\
\hline $\begin{array}{c}\text { Ferraz e Torres } \\
\mathbf{( 2 0 0 4 )}\end{array}$ & $\begin{array}{l}\text { Acessibilidade, frequência de atendimento, tempo de viagem, lotação, } \\
\text { confiabilidade, segurança, características dos veiculos, características dos locais } \\
\text { de parada, sistema de informação, conectividade, comportamento dos } \\
\text { operadores e estado das vias }\end{array}$ \\
\hline $\begin{array}{c}\text { Transit Capacity } \\
\text { and Quality of } \\
\text { Service Manual } \\
\text { (TCRP, 2003) }\end{array}$ & $\begin{array}{l}\text { Frequência, horas de serviço, cobertura do serviço, demanda de passageiros, } \\
\text { confiabilidade do serviço, diferença de tempos de viagem entre automóvel e }\end{array}$ \\
\hline & $\begin{array}{l}\text { Mercados regulamentados ou sem diferenciação de produtos, produto intangível, } \\
\text { produção e consumo simultâneos, grandes oscilações de demanda, }\end{array}$ \\
Lima Jr. (1995) & $\begin{array}{l}\text { indivisibilidade da oferta, processos e produtos heterogêneos, satisfação com o } \\
\text { produto e com o processo, interação com o meio ambiente, rede de processos e } \\
\text { parcerias e diferenças tecnológicas. }\end{array}$ \\
\hline
\end{tabular}

Fonte: Rodrigues (2008)

Cabe ressaltar que Reck (2016) aponta atributos a serem considerados pelos usuários de um sistema de transporte público, porém, esses atributos são percebidos de maneiras diferentes em relação ao transporte individual.

Dentre os itens supracitados, Quadro 3.1, Lima Jr. (1995) lembra que alguns indicadores de qualidade não são utilizados pelos mercados de serviço de transporte por entenderem que este último se constitui em uma atividade meio e, por isso, a variável "qualidade" não é frequentemente explorada. A relação dos indicadores, com os respectivos motivos/justificativas está descrita no Quadro 3.2:

Porém, como o objetivo dessa pesquisa é a aferição da percepção de qualidade, por parte dos usuários, acerca do sistema de transporte individual de passageiros, cabe a aplicação do método da Análise Multicritério de Apoio à Decisão (MCDA-C), baseada nos padrões de Bana e Costa et al (2003), que tem como finalidade aferir, qualitativamente, o serviço, por meio de atribuição de índices quantitativos. Ou seja, tornar possível a aferição, em números, acerca da percepção do usuário.

Quadro 3.2: Indicadores de qualidade e os motivos da sua não utilização pelos mercados de serviço de transporte. 


\begin{tabular}{|c|c|}
\hline Indicadores & \begin{tabular}{|l} 
Motivos/Justificativas \\
\end{tabular} \\
\hline $\begin{array}{l}\text { 1. Mercados regulamentados ou sem } \\
\text { diferenciação de produto }\end{array}$ & $\begin{array}{l}\text { As características de alguns mercados de transportes fazem } \\
\text { com que a qualidade não seja considerada como fator } \\
\text { estratégico importante para os prestadores de serviços. É o } \\
\text { caso dos mercados regulamentados. }\end{array}$ \\
\hline 2. Produto intangível & $\begin{array}{l}\text { O fato dos serviços serem intangíveis leva à impossibilidade de } \\
\text { transferência de posse, bem como de revenda. Transportar não } \\
\text { altera a forma física, mas sim agrega elementos intangíveis a } \\
\text { quem de se serve, é produzir valor associado ao tempo, ao } \\
\text { espaço e ao estado das coisas e das pessoas. }\end{array}$ \\
\hline 3. Produção e consumo simultâneos & $\begin{array}{l}\text { A inseparabilidade entre a produção e o consumo envolve os } \\
\text { consumidores nos processos, dificulta produções centralizadas, } \\
\text { traz variabilidades aos processos e cria a necessidade de } \\
\text { monitoração da qualidade em tempo real. O cliente participa da } \\
\text { produção do serviço. }\end{array}$ \\
\hline 4. Grandes oscilações de demanda & $\begin{array}{l}\text { As demandas de serviços apresentam grandes flutuações } \\
\text { temporais quando comparadas com a manufatura, tanto em } \\
\text { termos de intensidade, quanto em termos de freqüências. Isto, } \\
\text { associado ao fato dos serviços não serem armazenáveis, cria } \\
\text { diversas dificuldades relativas ao dimensionamento de } \\
\text { capacidades dos sistemas de prestação de serviços, trazendo } \\
\text { ineficiência para as operações e afetando os padrões de } \\
\text { qualidade oferecidos }\end{array}$ \\
\hline 5. Indivisibilidade da oferta & $\begin{array}{l}\text { As infra-estruturas viárias e os equipamentos necessários para a } \\
\text { produção de transportes normalmente demandam grandes } \\
\text { investimentos e obras que levam tempo para serem realizadas. } \\
\text { Estes elementos, quando comparados com as demandas } \\
\text { envolvidas, apresentam indivisibilidade. Ou seja, não é possível } \\
\text { construir a estrutura sob demanda, sob o risco de logo perder a } \\
\text { sua eficiência. }\end{array}$ \\
\hline 6. Produtos e processos heterogêneos & $\begin{array}{l}\text { A prestação do serviço trata-se de um processo de } \\
\text { transformação que converte entradas em saídas desejadas } \\
\text { através da aplicação apropriada de recursos. Ou seja, cada } \\
\text { viagem é um produto único e diferenciado, embora possa ser } \\
\text { agregado em conjuntos com características comuns. }\end{array}$ \\
\hline $\begin{array}{l}\text { 7. Satisfação com o resultado e com o } \\
\text { processo }\end{array}$ & $\begin{array}{l}\text { Além da satisfação com o resultado, existe também a satisfação } \\
\text { na participação do processo }\end{array}$ \\
\hline 8. Interação com o meio ambiente & $\begin{array}{l}\text { A prestação do serviço de transporte é reaizada em ambientes } \\
\text { não controlados (espaço aéreo, mar, ruas, cidades). Além de } \\
\text { serem sistemas abertos devido à participação do cliente, ocorrem } \\
\text { no meio ambiente, sujeito às suas intempéries. }\end{array}$ \\
\hline 9. Redes de processos e parcerias & $\begin{array}{l}\text { O sistema de transportes é participante e dependente de uma } \\
\text { rede entre empresas e/ou atividades, bem como suas demandas } \\
\text { são derivadas de outras demandas. }\end{array}$ \\
\hline 10. Diferenças tecnológicas & $\begin{array}{l}\text { As tecnologias envolvidas nos diversos tipos de transportes são } \\
\text { muito diferentes entre si e, consequentemente, apresentam } \\
\text { distintos padrões de desempenho. }\end{array}$ \\
\hline
\end{tabular}

Fonte: Lima Jr. (1995), adaptado pelo autor.

Assim, devido aos itens elencados por Lima Jr. (1995), no Quadro 3.2, constituírem motivos da não aplicação de critérios de qualidade ao transporte, por considerarem atividade meio, estes não devem ser considerados quando avaliada a qualidade de prestação de serviços de transporte. 
Para isso, é necessária a conceituação do termo usabilidade, que servirá como base para a determinação de critérios a serem avaliados pelos usuários do sistema de transporte individual de passageiros do Distrito Federal.

\subsection{USABILIDADE NO TRANSPORTE}

Segundo Rodrigues (2014), o conceito de usabilidade teve origem no campo da informática, para desenvolvimento de softwares, e ganhou importância a partir das décadas de 1970 e 1980 .

Drumond e Ferreira (2002), afirmam que a norma NBR ISO/IEC 9126-1 foi a primeira norma técnica a definir o termo usabilidade, conceituada como a "capacidade do produto de software de ser compreendido, aprendido, operado e atraente ao usuário, quando usado sob condições especificadas", podendo ser incluídos como usuários os operadores, usuários finais e usuários indiretos. De acordo com a norma, outros aspectos como: funcionalidade, confiabilidade e eficiência também afetarão a usabilidade, porém, não são classificados como tal.

Anjos e Moura (2005), apud Marques e Silva (2008), relacionam, de maneira sucinta, em um quadro demonstrativo, as métricas de usabilidade, de acordo com o ISO 9126, conforme reproduzido no Quadro 3.3.

Quadro 3.3: Métricas para o termo usabilidade, de acordo com o ISO 9126.

\begin{tabular}{|c|l|l|l|}
\hline Atributo & \multicolumn{1}{|c|}{ Significado } & Subcaracterísticas & Pergunta chave para a subcaracterística \\
\hline \multirow{4}{*}{ Usabilidade } & \multirow{2}{*}{$\begin{array}{c}\text { Evidencia a facilidade } \\
\text { para a utilização do } \\
\text { produto (é fácil de usar?) }\end{array}$} & Inteligibilidade & É fácil entender o conceito e a aplicação? \\
\cline { 3 - 5 } & & Apreensibilidade & É fácil aprender a usar? \\
\cline { 3 - 5 } & & Atratividade & A interface é agradável? Mantém a atenção? \\
\hline
\end{tabular}

Fonte modificada: Anjos e Moura (2005), apud Marques e Silva (2008).

Usabilidade é aplicável não só no contexto da informática, Cybis et al (2010) conceituam o termo como sendo a propriedade de ações que permite a interação do homem com determinado produto ou equipamento, que viabiliza o objeto pretendido principalmente de maneira mais confortável, fácil, interativa e eficiente possível. Trata da relação que se estabelece entre usuário, tarefa, equipamento e demais aspectos no ambiente pesquisado que, nessa pesquisa é o transporte individual de passageiros. De forma mais simplificada, Nielsen (1993) se refere à usabilidade como o quão bem os usuários podem utilizar determinada funcionalidade. 
Rodrigues (2014) informa que a chamada tríade de usabilidade, composta por acessibilidade, permanência e localização, é conceituada da seguinte forma: a) acessibilidade - permite ao usuário sua participação ou inclusão no sistema; b) permanência - significa decidir qual parte do sistema o usuário deseja percorrer e o momento em que deseja sair; e c) localização - é o mecanismo de orientação que ajudará o usuário saber quais são e onde encontrar as formas de deslocamento. Enfim, a usabilidade no transporte é um instrumento que permite a adequação do ambiente do sistema de transportes às necessidades de quem o utiliza.

Para a usabilidade no transporte, o mesmo autor define essa tríade como DAM (Decisão, Acesso e Movimentação):

- Decisão - Processo que determina os caminhos que serão trilhados nos espaços dos sistemas de transporte. As escolhas se baseiam nas informações disponíveis e na análise do contexto.

- Acesso - Trata sobre as regras e os meios de ingressar nos ambientes dos sistemas de transportes e variam para cada sistema.

- Movimentação - Mecanismo para realizar o deslocamento das pessoas nas áreas do sistema de transporte, com a finalidade de garantir o direito de ir e vir das pessoas.

De maneira geral a usabilidade trata da identificação daqueles critérios fundamentais (qualitativos) e indispensáveis para que haja a interação satisfatória e adequada entre o usuário e o serviço, agregando valor ao serviço.

A subjetividade da qualidade pode ser identificada pelos critérios de medição da usabilidade adotados por Shackel (1991), Nielsen (1993), Jordan (1993) e (1998), Cybis et al (2010), consubstanciados no Quadro 3.4. 
Quadro 3.4: Medição da usabilidade

\begin{tabular}{|c|c|c|c|}
\hline Autores & \multicolumn{3}{|c|}{ Crité rios para medição de us abilidade } \\
\hline Shackel (1991) & $\begin{array}{l}\text { - Eficiência } \\
\text { - Flexibilidade }\end{array}$ & \multicolumn{2}{|c|}{$\begin{array}{l}\text { - Aprendizado } \\
\text { - Atitude }\end{array}$} \\
\hline Nielsen (1993) & $\begin{array}{l}\text { - Aprendizagem } \\
\text { - Eficiência } \\
\text { - Memorização }\end{array}$ & \multicolumn{2}{|l|}{$\begin{array}{l}\text { - Erros } \\
\text { - Satisfação }\end{array}$} \\
\hline $\begin{array}{l}\text { Jordan (1993) } \\
\text { e (1998) }\end{array}$ & \begin{tabular}{|l} 
- Intuitividade \\
- Aprendizagem \\
- Performance do \\
usuário com \\
esperiência (PUE)
\end{tabular} & \multicolumn{2}{|c|}{$\begin{array}{l}\text { - Potencial do sistema } \\
\text { - Reusabilidade }\end{array}$} \\
\hline $\begin{array}{l}\text { Cybis et al } \\
\text { (2010) }\end{array}$ & $\begin{array}{l}\text { Problemas de estrutura: } \\
\text { - Barreira } \\
\text { - Obstáculo } \\
\text { - Ruído }\end{array}$ & $\begin{array}{l}\text { Problemas de Tipo de Tarefa: } \\
\text { - Principal } \\
\text { - Secundária }\end{array}$ & $\begin{array}{l}\text { Problemas de Tipo do Usuário: } \\
\text { - Geral } \\
\text { - Inicial } \\
\text { - Avançado } \\
\text { - Especial }\end{array}$ \\
\hline
\end{tabular}

Fonte: Rodrigues (2014)

A eficiência, segundo Shackel (1991), apud Silveira Jr. et al. (2015), está relacionada à velocidade e quantidade de erros percebidos durante a interação; flexibilidade é a capacidade do produto de se adaptar a mais atividades do que aquelas para as quais foi idealizado; aprendizado une a facilidade de compreensão e retenção a médio ou longo prazo; e atitude mede o desgaste sofrido pelo usuário durante a interação.

Além daqueles critérios definidos por Shackel (1991), apud Silveira Jr. et al. (2015), Nielsen (1993) elenca os erros, que são os problemas que ocorrem no utilização, e a satisfação, que consiste no sentimento do usuário acerca do produto.

Já os critérios trazidos por Jordan (1993) acrescentados posteriormente por Jordan (1998), e que diferem dos demais, são: I) a intuitividade, que significa a capacidade de o usuário se familiarizar com o produto em sua primeira utilização; II) a performance do usuário com experiência (PUE), que significa a capacidade ou nível do usuário já experiente em reutilizar o sistema; III) o potencial do sistema, que significa o ponto máximo que o sistema poderia atingir; e IV) a reusabilidade, que significa a capacidade do usuário retomar a utilização do sistema sem ter contato por um período de tempo. Segue abaixo (Figura 3.1) a ilustração da curva conceitual de Jordan (1998). 


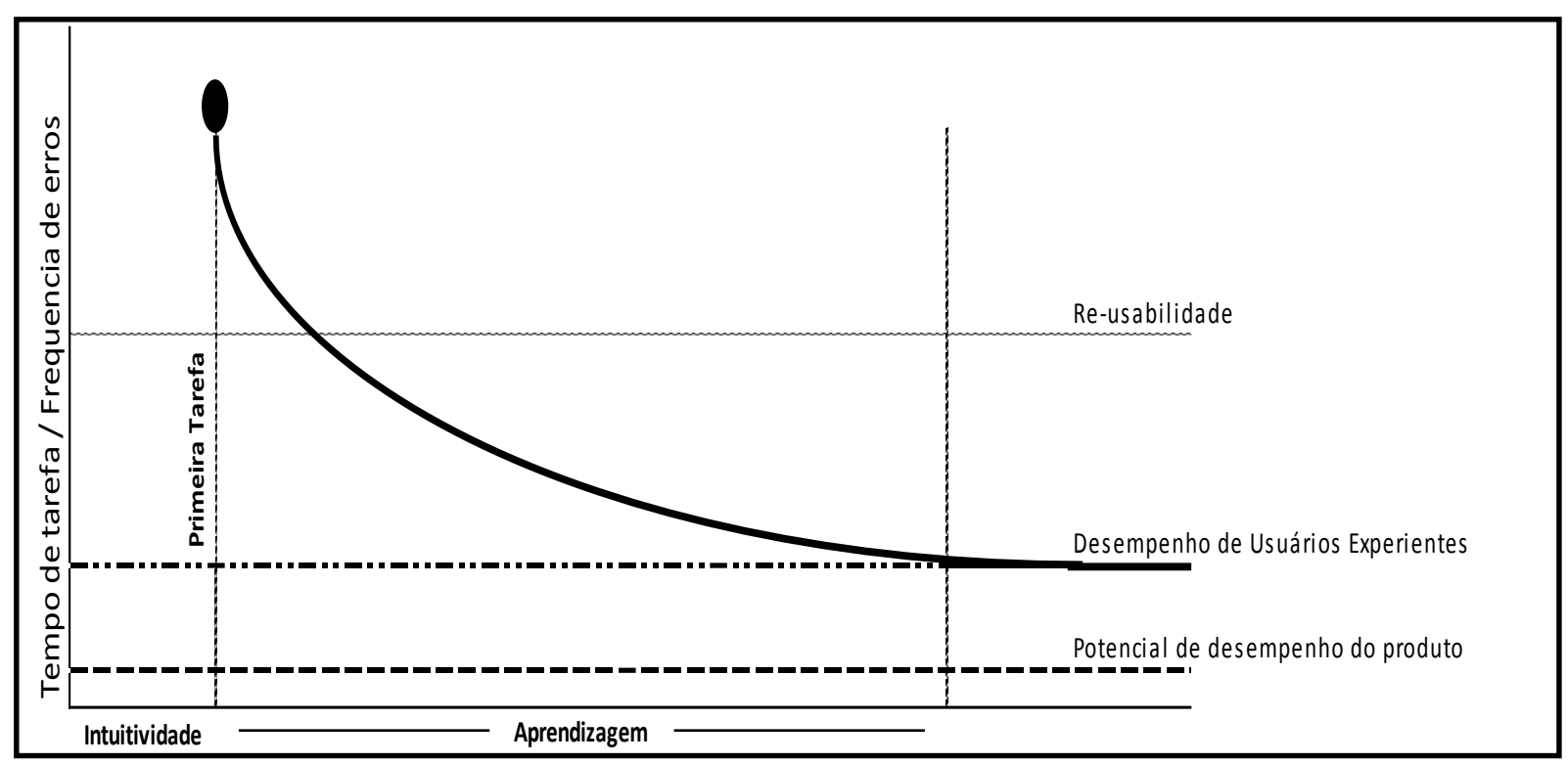

Figura 3.1: Curva conceitual dos componentes de usabilidade segundo Jordan (1998)

Fonte: Jordan (1998)

O enfoque dado por Cybis et al (2010) são os tipos de problemas mais comuns na usabilidade, que podem ser encontrados na estrutura, no tipo de tarefa ou no tipo de usuário.

Importante observar os problemas apontados por Cybis et al (2010) em relação ao tipo do usuário, ou público-alvo, pois a percepção de usabilidade para cada tipo de usuário pode ser diferente e esse fato deve ser considerado, a fim de evitar erros na avaliação. Deve-se, portanto, dar prioridade aos aspectos mais relevantes para cada público-alvo, de acordo com suas limitações e individualidades (Rodrigues, 2014).

Tomando como base a Figura 3.2, a versão mais recente da norma NBR ISO 9241, parte 11, conceitua usabilidade como a "capacidade que o produto apresenta para ser utilizado por usuários específicos para alcançar metas especificas com eficácia, eficiência e satisfação, em um contexto de uso específico". Sendo que a eficácia significa o grau de precisão e de abrangência obtidos pelo usuário na interação com o sistema, para atingimento dos objetivos; eficiência é a proporção de recursos empregados para que o usuário atinja seus objetivos; e satisfação é entendida como o grau de conforto e de reação favorável por quem está operando em relação ao uso do sistema. 


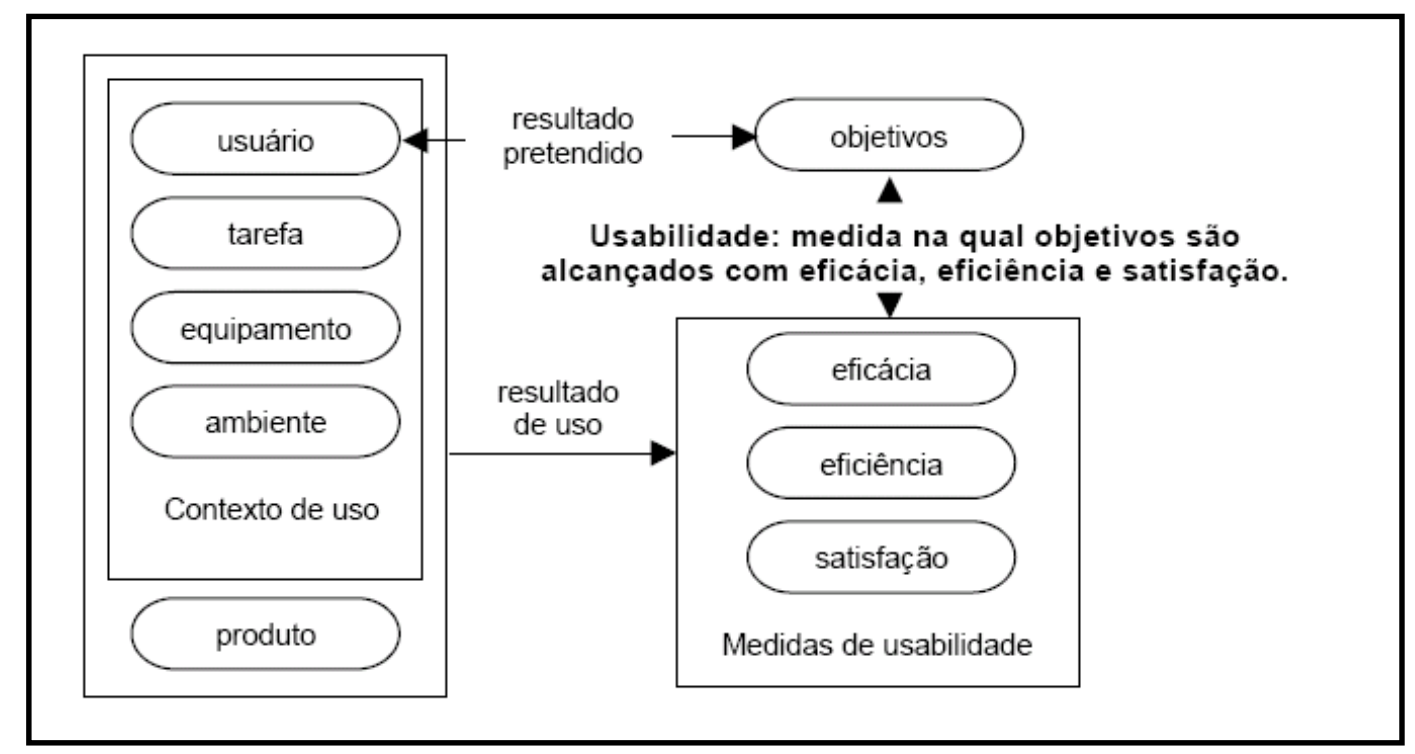

Figura 3.2: Estrutura da usabilidade

Fonte: ISO 9241-11

A referida norma formula recomendações para a mensuração das qualidades, quais sejam: a) especificação e mensuração da usabilidade; b) especificação e avaliação da usabilidade durante o projeto; e c) especificação e avaliação da usabilidade durante o uso.

A medição da usabilidade leva em conta a observação da complexidade das interações entre o usuário e o produto, os elementos das operações que envolvem o contexto de uso (usuário, tarefa, equipamento e ambiente) e os objetivos do uso, pois a usabilidade não deve ser vista como uma propriedade isolada do produto.

Nielsen (1995) defende a análise heurística para avaliar a usabilidade de um sistema, por ser um método rápido e barato. Recomenda, ainda, que seja realizada por especialistas da área, porém, não há impedimento para que usuários realizem de acordo com os critérios de avaliação.

A avaliação heurística é uma técnica de inspeção de usabilidade em que especialistas orientados por um conjunto de princípios de usabilidade avaliam se os elementos de interface com o usuário estão de acordo com esses princípios (ou heurísticas) (Nielsen, 1995, apud Beluzo et al., 2014).

Nielsen (1995b) apresentou as 10 (dez) principais heurísticas de usabilidade, conforme descrito no Quadro 3.5. 
Quadro 3.5: Heurísticas de usabilidade

\begin{tabular}{|l|l|}
\hline \multicolumn{2}{|c|}{ Heurística } \\
\hline 1. Visibilidade do status do sistema & $\begin{array}{l}\text { O sistema deve manter o usuário informado sobre o que } \\
\text { está acontecendo, fornecendo um feedback em tempo } \\
\text { razoável. }\end{array}$ \\
\hline $\begin{array}{l}\text { 2. Equivalência entre sistema e mundo } \\
\text { real }\end{array}$ & $\begin{array}{l}\text { O sistema deve falar a linguagem do usuário, ao invés de } \\
\text { utilizar termos técnicos. Deve seguir as convenções do } \\
\text { mundo real. }\end{array}$ \\
\hline 3. Controle do usuário e liberdade & $\begin{array}{l}\text { O sistema deve fornecer suporte para ações como } \\
\text { "desfazer" e "refazer", bem como facilidade para sair de um } \\
\text { estado indesejado. }\end{array}$ \\
\hline 4. Consistência e padrões & $\begin{array}{l}\text { O sistema deve seguir convenções, não deixando a cargo } \\
\text { do usuário a adivinhação de significados. }\end{array}$ \\
\hline $\begin{array}{l}\text { 5. Prevenção de erros } \\
\text { memorização }\end{array}$ & $\begin{array}{l}\text { Solicitar a confirmação do usuário antes de executar } \\
\text { comandos, a fim de evitar escolhas equivocadas. }\end{array}$ \\
\hline 7. Flexibilidade e eficiência de uso & $\begin{array}{l}\text { Minimizar a carga de memória do usuário, tornando objetos, } \\
\text { ações e opções visíveis, deixando as instruções para usar o } \\
\text { sistema sempre visíveis e localizáveis. }\end{array}$ \\
\hline 8. Estética e design minimalista & $\begin{array}{l}\text { O sistema deve atender tanto usuário inexperientes quanto } \\
\text { experientes. }\end{array}$ \\
\hline $\begin{array}{l}\text { 9. Ajudar os usuários a reconhecer, } \\
\text { diagnosticar e recuperar ações erradas. }\end{array}$ & $\begin{array}{l}\text { Priorizar informações relevantes, de forma que as } \\
\text { irrelevantes não reduzam a visibilidade das relevantes. } \\
\text { sensimples, indicando precisamente o problema e sugerindo } \\
\text { uma solução. }\end{array}$ \\
\hline 10. Ajuda e dcumentação & $\begin{array}{l}\text { Qualquer informação de ajuda deve ser fácil de buscar, } \\
\text { focada na tarefa do usuário. }\end{array}$ \\
\hline
\end{tabular}

Fonte: Nielsen (1995b), modificado pelo autor.

Rosa e Moraes (2005), apud Beluzo et al. (2014), afirmam que os testes de usabilidade possuem raízes na psicologia experimental, sendo que durante a sua aplicação pede-se aos participantes que executem uma ou mais tarefas bem determinadas, onde um conjunto de medições são obtidas e, a partir dessas medições, é realizado algum tipo de análise estatística.

Por isso, é importante que os testes de usabilidade consistam em avaliar o desempenho dos usuários, em atividades típicas, especialmente preparadas conforme a realidade para as quais o sistema foi projetado.

\subsection{MÉTODOS DE AVALIAÇÃO DE QUALIDADE EM TRANSPORTES E APLICAÇÕES}

Este capítulo tem a intenção de demonstrar alguns métodos já abordados para a avaliação da qualidade de serviços de transporte, de acordo com metodologias e técnicas diferentes e que 
abordaram a ótica dos diversos atores envolvidos na prestação dos serviços, tais como empresas de transporte, gestores, usuários dos sistemas e sociedade em geral.

Ferraz e Torres (2001) utilizam uma metodologia para avaliação global da qualidade dos sistemas de transporte público coletivo urbano, e consideram o nível de satisfação de todos os atores envolvidos, desde usuários, trabalhadores, empresas, gestores públicos, sociedade e especialistas, conforme parâmetros de qualidade diferentes para cada ator. As respectivas pesquisas foram feitas por técnicos especializados junto aos atores e o resultado foi classificado de acordo com padrões pré-estabelecidos.

Cruz et al. (2013) tratam da avaliação de qualidade do transporte urbano semi-público na modalidade táxi segundo a percepção do usuário. Em seu trabalho foi mensurada a qualidade de serviços internos de uma só empresa de táxi sob a ótica do cliente. Para isso, foi realizado estudo descritivo com a aplicação de questionários aos clientes da empresa e, para a coleta de dados, foi utilizada a escala SERVPERF, em que são utilizados como base cinco fatores que influenciam a decisão do cliente acerca da avaliação sobre o serviço prestado: aspectos tangíveis, presteza, segurança e empatia. Os critérios de avaliação foram baseados na escala Likert e, por fim, o estudo concluiu que ainda era possível maximizar a avaliação positiva obtida pela empresa.

Martins (2015) utiliza o método Desdobramento da Função Qualidade - QFD para criar um índice de qualidade do transporte público por ônibus a partir da definição de serviço adequado, dividindo o trabalho em três etapas: 1) definição dos indicadores a serem utilizados, com base no serviço adequado definido em lei e pesquisa junto aos usuários para identificação dos atributos relevantes. 2) realização de nova pesquisa com os usuários com a finalidade de atribuir pesos a cada atributo e para cada indicador do índice proposto. 3) por fim, foi realizada a validação do índice, quando aplicado na cidade de Belo Horizonte/MG. Da pesquisa foi concluído que a cidade apresentou índice "admissível" da qualidade do transporte público, necessitando pouco esforço em atributos específicos.

Ribeiro e Freitas (2012) tratam da avaliação da qualidade do serviço de transporte rodoviário intermunicipal, segundo a percepção dos usuários. No estudo, primeiramente, foram identificados o grau de importância dos critérios e o grau de satisfação dos passageiros em relação aos critérios considerados. Assim, após identificados dezessete critérios, foram elaborados questionários para captarem o perfil e a intensidade do julgamento sobre o grau de 
percepção e satisfação dos usuários. Foi realizada uma amostragem por conveniência (nãoprobabilística), das respostas aos questionários e, por meio da análise Importância-Satisfação, os resultados gerados foram agrupados de acordo com o grau de satisfação dos usuários. Por fim, por meio da técnica de regressão linear múltipla, foram obtidos os resultados que permitiram a interpretação da importância relativa de cada variável ao modelo, bem como as associações entre as variáveis, informações essas que podem subsidiar a tomada de decisões.

Marins (2007) avaliou e classificou o serviço de transporte público conforme a percepção dos usuários por meio da abordagem multicritério Electre Tri (Yu, 1992, apud Marins, 2007), que consiste em uma ferramenta de auxílio à tomada de decisão multicritério, que serve para classificar e analisar o desempenho das empresas de transporte em observância aos critérios percebidos. O trabalho foi dividido em cinco etapas: 1) Modelagem do problema, onde foram definidos os elementos e os procedimentos que comporiam o modelo de avaliação, momento em que foi utilizado o método de Electre Tri e, subsidiariamente, foi utilizada a escala Likert para a elaboração dos questionários, para que os entrevistados pudessem expressar seu grau de aprovação ou desaprovação em relação a cada afirmação; 2) Execução, em que foi feita a coleta de dados junto aos usuários; 3) Análise dos dados coletados e dos resultados; 4) Planejamento, que identificou as ações corretivas viáveis e que, depois de implementadas poderiam proporcionar melhorias no nível de serviço; e 5) Implementação das ações corretivas.

Azambuja (2002) utiliza a Análise Envoltória de Dados (AED) para propor um conjunto de procedimentos para aferir a eficiência na gestão do transporte público por ônibus em municípios brasileiros. O método AED constitui-se em uma técnica que permite trabalhar com múltiplos produtos, sem a necessidade de obter informações sobre os preços dos insumos, produtos e demais hipóteses para redução de custos. A autora construiu um modelo para analisar a eficiência dos transportes coletivos por ônibus a partir de variáveis disponíveis nos anuários de transportes urbanos da ANTP. Assim, foi possível identificar municípios como exemplos de boas práticas na prestação do referido serviço, que servem de referência para os demais, bem como foi demonstrada a possibilidade de o método AED ser utilizado pelos órgãos gestores para avaliarem e monitorarem o desempenho dos operadores.

Maia (2013) avalia a qualidade do transporte público sob a ótica da mobilidade urbana sustentável na cidade de Fortaleza, por meio do Índice de Mobilidade Urbana Sustentável (IMUS). Desenvolvido por Costa (2008) e baseado na metodologia Multicritério de Apoio à Decisão Construtivista (MCDA-C), é obtido através da composição de nove "Domínios", que 
se dividem em trinta e sete "Temas" e que subdividem em oitenta e sete "Indicadores". Costa (2008) especificou pesos para que o índice variasse de zero (para a pior situação) a um (melhor situação).

Para o estudo realizado por Maia (2013), os cálculos foram restringidos àqueles indicadores diretamente relacionados ao segmento e, por isso, foram analisados somente sete Temas com vinte e dois Indicadores no total. A coleta de dados foi baseada, principalmente, em entrevistas com técnicos e gestores de órgãos de desenvolvimento urbano e do sistema de transportes da cidade e pesquisas em sites oficiais da internet, e a análise contemplou cenários para os anos de 1992, 2000, 2010 e 2014. Por fim, foi percebida diferença a maior entre os IMUS da cidade de Fortaleza e da região metropolitana da mesma cidade, bem como foi possível identificar os índices máximos, mínimos e reais de cada cenário.

Jammal (2010) usa o método Desdobramento da Função Qualidade - QFD para avaliar os requisitos de qualidade do Sistema de Transporte Público Coletivo da cidade de São José do Rio Preto. O referido método permite a captura das necessidades dos clientes e conduz essas informações durante o processo produtivo, de forma a entregar ao cliente um produto ou serviço desejado, pois a ferramenta QFD parte dos requisitos expostos pelos clientes e realiza um processo de desdobramento, transformando esses desdobramentos em especificações técnicas/ características do produto esperado pelo cliente.

Na primeira etapa da pesquisa de Jammal (2010), foram obtidos os requisitos de qualidade por meio de questionários aplicados junto a representantes de empresas operadoras e órgão gestor do sistema. Após, foram extraídas as características de qualidade e elaborada a Tabela de Desdobramento das Características da Qualidade. Aplicados dois questionários, de requisitos primários e secundários, em uma amostra da população, foram identificados os itens de qualidade exigida pelos usuários e incorporados aos requisitos de qualidade, formando a Matriz de Qualidade. A partir daí foi possível criar outras Matrizes de Correlação de Qualidade a fim de investigar a percepção de qualidade dos clientes com os requisitos estipulados por empresas e órgão gestor do sistema.

Santos (2014) elaborou propostas para melhoria contínua da qualidade do transporte público coletivo do Distrito Federal por meio da escala Servqual, baseada nos determinantes genéricos da qualidade propostos por Parasuraman et al. (1985, 1993) apud, Santos (2014). Porém, procurou adaptar a escala Servqual original para aplicação em sua pesquisa. Assim, foi 
elaborado um método mais flexível para captar as opiniões e sugestões dos usuários, a fim de ajudar a identificar as proposições de melhoria. Por fim, foram tabulados os resultados das pesquisas e realizados quadros comparativos entre satisfação e expectativas dos usuários, obtendo como resposta os gaps (diferença entre pontuação mínima e máxima) de cada determinante.

Foram encontrados diversos trabalhos acerca da qualidade do transporte, os quais utilizaram o método de MCDA-C, em que o foco principal foi a mensuração da qualidade dos serviços de transporte coletivo urbano ou intermunicipal. Este trabalho de pesquisa também utiliza esse mesmo método, visto que não há estudos ainda acerca da utilização do MCDA-C para mensurar a percepção de qualidade do usuário do Transporte Individual de passageiros: público (Táxi) e privado (Uber), principalmente em relação a esses serviços prestados no território do Distrito Federal.

Dessa forma, para a presente pesquisa, realizada em relação ao serviço de transporte individual público e privado, foi necessário utilizar critérios diferentes daqueles utilizados para a aferição de qualidade do transporte público coletivo, visto suas características específicas, principalmente em relação ao público-alvo (usuários).

Assim, a avaliação multicritério de apoio à decisão que leve em consideração a opinião dos usuários dos dois sistemas de transporte individual (público e privado) pode ser de grande valia para compreendê-los, devido ao estabelecimento de parâmetros comparativos.

Avaliações individuais dos dois sistemas de transporte individuais de passageiros, utilizando das mesmas referências teóricas e mesmas ferramentas metodológicas e sendo coletados dados no mesmo período, permitirá estabelecer parâmetros comparativos entre ambos.

À medida que se identifica a percepção dos seus usuários acerca da qualidade do serviço, espera-se a obtenção de resultados que permitam orientar pesquisadores e gestores sobre possíveis pontos críticos a serem ajustados a fim de melhor corresponder às expectativas dos usuários e, consequentemente, auxiliar na tomada de decisões. 


\section{MODELO MULTICRITÉRIO DE APOIO À DECISÃO CONSTRUTIVISTA}

Este capítulo é dedicado à discussão acerca da construção do modelo multicritério, para posterior mapeamento estruturado com a finalidade de investigar a percepção, pelos usuários, acerca dos aspectos relevantes de qualidade do sistema para os gestores e especialistas, com lócus da pesquisa centrado em dois sistemas de transporte individual de passageiros (público: Táxi; e privado: Uber).

Segundo Rodrigues (2014), a metodologia indica a trilha para a percepção da usabilidade de um sistema em estudo, com base em um modelo matemático, que considere a preferência do decisor e, também, a opinião do usuário. Monitorar o nível de satisfação dos usuários é estratégico para a formulação de inovações ao sistema, pois os gestores podem utilizar, como base para a tomada de decisão, as solicitações dos usuários de transporte.

Segundo Ensslin et al. (2001), o processo de apoio à decisão é dividido em quatro passos: 1) identificação do contexto decisório; 2) estruturação do problema; 3 ) estruturação do modelo multicritério; e 4) avaliação das ações potenciais.

A identificação do contexto decisório é apresentada no próximo capítulo, entretanto, as estruturações do problema e do modelo multicritério são consideradas conjuntamente no subitem 4.2. E, por fim, as avaliações das ações potenciais são tratadas em capítulo à parte.

\subsection{IDENTIFICAÇÃO DO CONTEXTO DECISÓRIO}

Nesta etapa, devem ser definidos os aspectos necessários ao início do processo de apoio à decisão, tais como a apresentação do rótulo, que norteará todas as ações avaliativas no modelo; identificar os atores envolvidos na tomada de decisão e escolher os decisores que participarão da construção do modelo; identificar o tipo de ação que será avaliada pelo modelo multicritério; e decidir o tipo de avaliação a ser feita através do modelo, quer dizer, escolher a problemática de referência (Ensslin et al., 2001).

O rótulo da pesquisa trata do próprio título, que servirá para nortear o trabalho. Ensslin et al. (2001) assevera que ele tem a função fundamental de delimitar o campo a ser examinado, determinando os itens principais, considerados mais estratégicos para a resolução do problema. Neste momento, sugere-se o seguinte rótulo para a pesquisa "qualidade do sistema de transporte individual de passageiros do Distrito Federal”. 


\subsubsection{IDENTIFICAÇÃO DOS ATORES}

A etapa de identificação dos atores envolvidos no processo decisório é importante para a construção do modelo multicritério, pois eles que emitirão os valores necessários à construção do modelo. Os atores são divididos em dois grupos: intervenientes e agidos.

Os intervenientes são aqueles que participam diretamente do processo decisório e que farão prevalecer seus valores, enquanto os agidos apenas sofrerão de forma passiva as consequências da implementação da decisão tomada.

Ensslin et al. (2001) afirmam que existem três tipos de atores intervenientes: decisores, que são aqueles a quem foi formalmente delegado o poder de decisão; representantes, incumbidos pelo decisor para representá-lo; e facilitador, o qual possui como atribuição facilitar e apoiar o processo de decisão através de ferramentas construídos para essa finalidade.

De acordo com a estrutura existente no sistema de transporte público individual de passageiros (Táxi), podem ser identificados mais de um interveniente decisor, quais sejam: o SINPETAXI, na figura do seu presidente ou da sua alta cúpula; Diretoria da SEMOB, por meio do Secretário de Mobilidade ou ainda por outras diretorias responsáveis pelo serviço de táxi, tal como a SUFISA, órgão responsável pela fiscalização dos serviços de táxi prestados no âmbito do DF.

Em relação ao sistema de transporte individual privado (Uber), são decisores aqueles participantes da alta cúpula representante da empresa em Brasília e, quando não é possível contar com os decisores acima mencionados, são seus representantes aqueles especialistas com experiência acerca dos sistemas avaliados, tais como empregados ou pesquisadores.

Como moderador, para atuar no processo decisório de criação dos critérios e taxa de contribuição e esforços para mudança de nível, figura o pesquisador. Por fim, os agidos são compostos por usuários dos dois sistemas.

Segue abaixo (Figura 4.1) o esquema contendo os atores envolvidos no processo de percepção da qualidade do serviço de transporte individual de passageiros: 


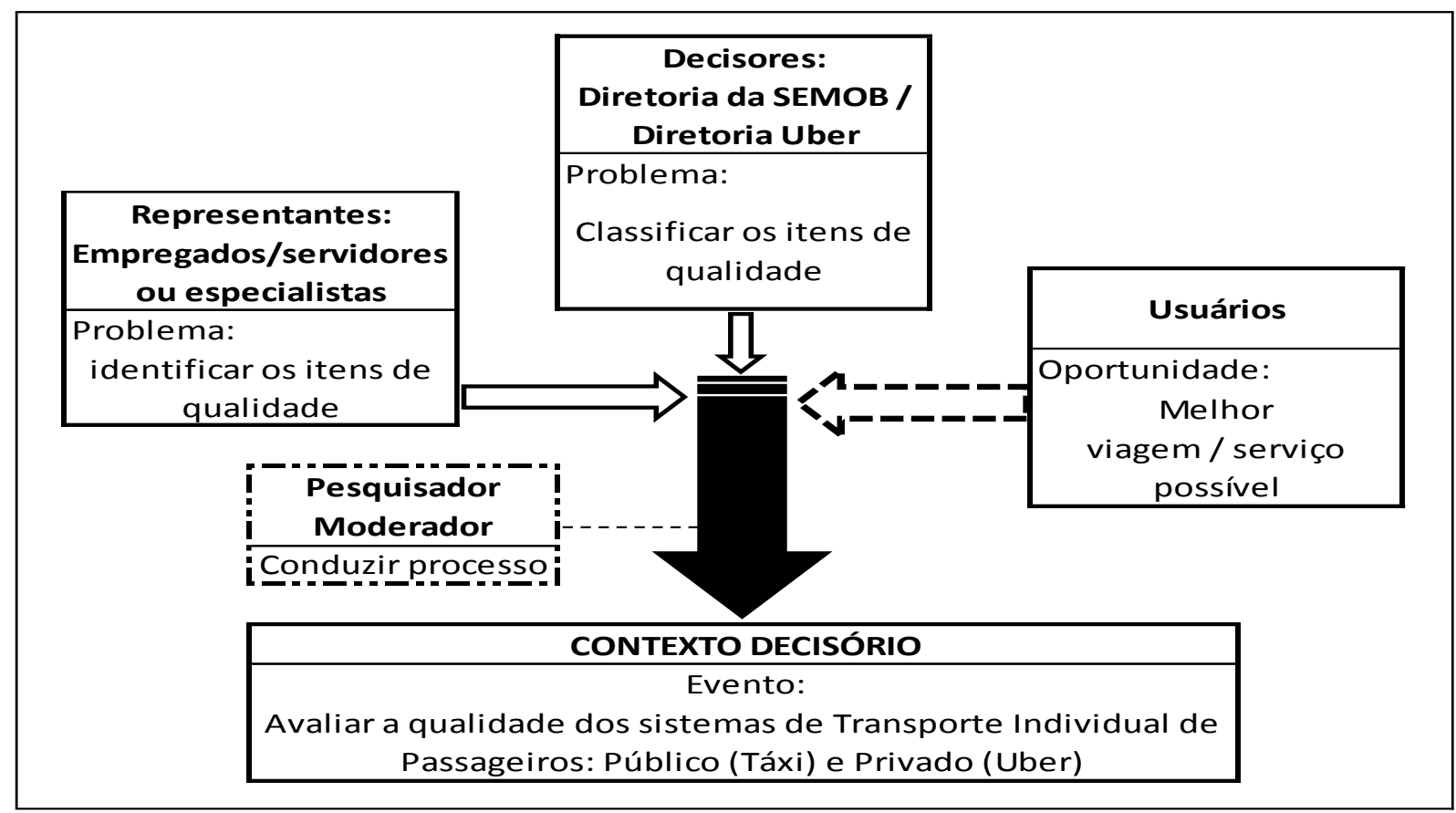

Figura 4.1: Atores do processo de percepção da qualidade do serviço de transporte individual de passageiros

Após a identificação dos atores, foram definidas com os especialistas (pesquisadores e servidores públicos que trabalham na área), em consenso, a identificação dos quesitos de qualidade dos sistemas e a definição dos critérios e taxa de substituição e esforços para mudança de níveis, com a finalidade de se criar um instrumento de coleta de dados junto aos usuários.

Segundo Rodrigues (2014), a utilização de técnica de brainstorming entre os decisores, no Método Multicritério, é importante e possui a finalidade de contribuir para as etapas de elaboração das famílias dos elementos primários de avaliação, criação de mapa cognitivo e identificação dos critérios, seus pesos e limites de discriminação, para subsidiar o instrumento de verificação da percepção da qualidade pelo usuário.

Baptista (2004) conceitua brainstorming como uma técnica de geração de ideias, a qual possui como diretriz o estímulo de respostas criativas e espontâneas em um grupo de pessoas, a fim de orientar a solução de um determinado problema.

\subsubsection{TIPO DE AÇÃO A SER AVALIADA}

Nesta etapa foi realizado o levantamento dos Elementos Primários de Avaliação (EPA), que, segundo Ensslin et al. (2001), são os resultados das primeiras reflexões sobre o rótulo/título para construção de itens primários significativos no contexto decisório. 
O sentido de cada conceito enumerado está baseado na formação da ação e gera resultado significativo para os atores envolvidos, por isso, nessa fase foram realizadas entrevistas com os representantes e especialistas, individualmente, e reunião, onde foi utilizada a ferramenta do brainstorming para reuni-los no mesmo ambiente e fazer a apropriação das ideias (pontos de vista) geradas nas discussões. O pesquisador tem papel fundamental na mediação e identificação dos quesitos mais relevantes de qualidade para o sistema.

Como sugestão de elementos primários a serem discutidos junto aos decisores foram apresentados no Quadro 4.1, a seguir, os Elementos Primários de Avaliação - EPA, que foram previamente levantados em conversas com pesquisadores e profissionais que atuam na área de gestão, regulação e fiscalização dos serviços de transporte do DF, (servidores das carreiras de Gestão Pública e de Auditoria Fiscal de Atividades Urbanas - Especialidade de Transportes), como pontos importantes considerados sob suas perspectivas:

Quadro 4.1: Elementos Primários de Avaliação

\begin{tabular}{|c|c|}
\hline Elementos Primários de Avaliação & Detalhamento do elemento \\
\hline Exigência profissional & $\begin{array}{l}\text { Dirigibilidade: conduzir o veículo com movimentos suaves, de } \\
\text { modo que não haja movimentos bruscos; postura do motorista; } \\
\text { tratar os clientes com gentileza, empatia, prestatividade. }\end{array}$ \\
\hline Conhecimento do trajeto & $\begin{array}{l}\text { Conhecer o menor trajeto a ser realizado entre origem e } \\
\text { destino; Conhecer rotas alternativas para fugir de } \\
\text { engarrafamentos, acidentes, etc ; Pontualidade. }\end{array}$ \\
\hline Conforto do veículo & $\begin{array}{l}\text { Espaço interno adequado; ambiente agradável; limpeza e } \\
\text { conservação do veículo; existência de serviços de bordo } \\
\text { adicionais. }\end{array}$ \\
\hline Custo do serviço & $\begin{array}{l}\text { Valor despendido com o serviço; facilidade de pagamento; } \\
\text { controle do valor a ser pago (antes ou durante a viagem); } \\
\text { Transparência. }\end{array}$ \\
\hline Intangíveis e valor da marca & $\begin{array}{l}\text { Valorar a imagem da marca e a imagem do serviço prestado } \\
\text { naquele momento, com detalhamento da relevância do serviço } \\
\text { e da marca }\end{array}$ \\
\hline Acessibilidade & $\begin{array}{l}\text { Facilidade de utilizar o aplicativo ou instrumento necessário à } \\
\text { ao usufruto do serviço; funcionalidade do aplicativo ou outro } \\
\text { meio utilizado; abrangência do atendimento do serviço } \\
\text { (lugares que atende); compatibilidade do serviço com Pessoas } \\
\text { com Necessidades Especiais (PNE). }\end{array}$ \\
\hline Tempo & $\begin{array}{l}\text { Tempo de aguardo até a chegada do veículo; monitoramento } \\
\text { da chegada do veículo; horário de funcionamento do serviço. }\end{array}$ \\
\hline Segurança do sistema & $\begin{array}{l}\text { Identificar adequadamente se o carro está credenciado junto ao } \\
\text { sistema; identificar se o motorista é credenciado no sistema. }\end{array}$ \\
\hline Sistema de apoio & $\begin{array}{l}\text { Atendimento no "pós-venda"; Atendimento para possíveis } \\
\text { sugestões ou reclamações acerca do serviço prestado. }\end{array}$ \\
\hline Emissão de poluentes & $\begin{array}{l}\text { Verificar se emissão de poluentes encontra-se adequada; } \\
\text { Verificar nível de ruído. }\end{array}$ \\
\hline
\end{tabular}

Fonte: o autor 
Tezza et al. (2010) afirmam que os EPA têm como objetivo, gerar entendimento e definir os limites entre o pretendido e o mínimo aceitável. Na sequência, Com base nos elementos primários de avaliação já consolidados, estes foram confrontados com o rótulo da pesquisa, por meio de "filtragem" das ideias, para definir os Pontos de Vista Fundamentais (PVF). Ou seja, os elementos ratificados após a filtragem passaram de Elementos Primários de Avaliação para Pontos de Vista Fundamentais (PVF), que passam a compor a árvore ou vínculos. A Figura 4.2, abaixo, ilustra o processo de "filtragem" realizado durante o brainstorming.

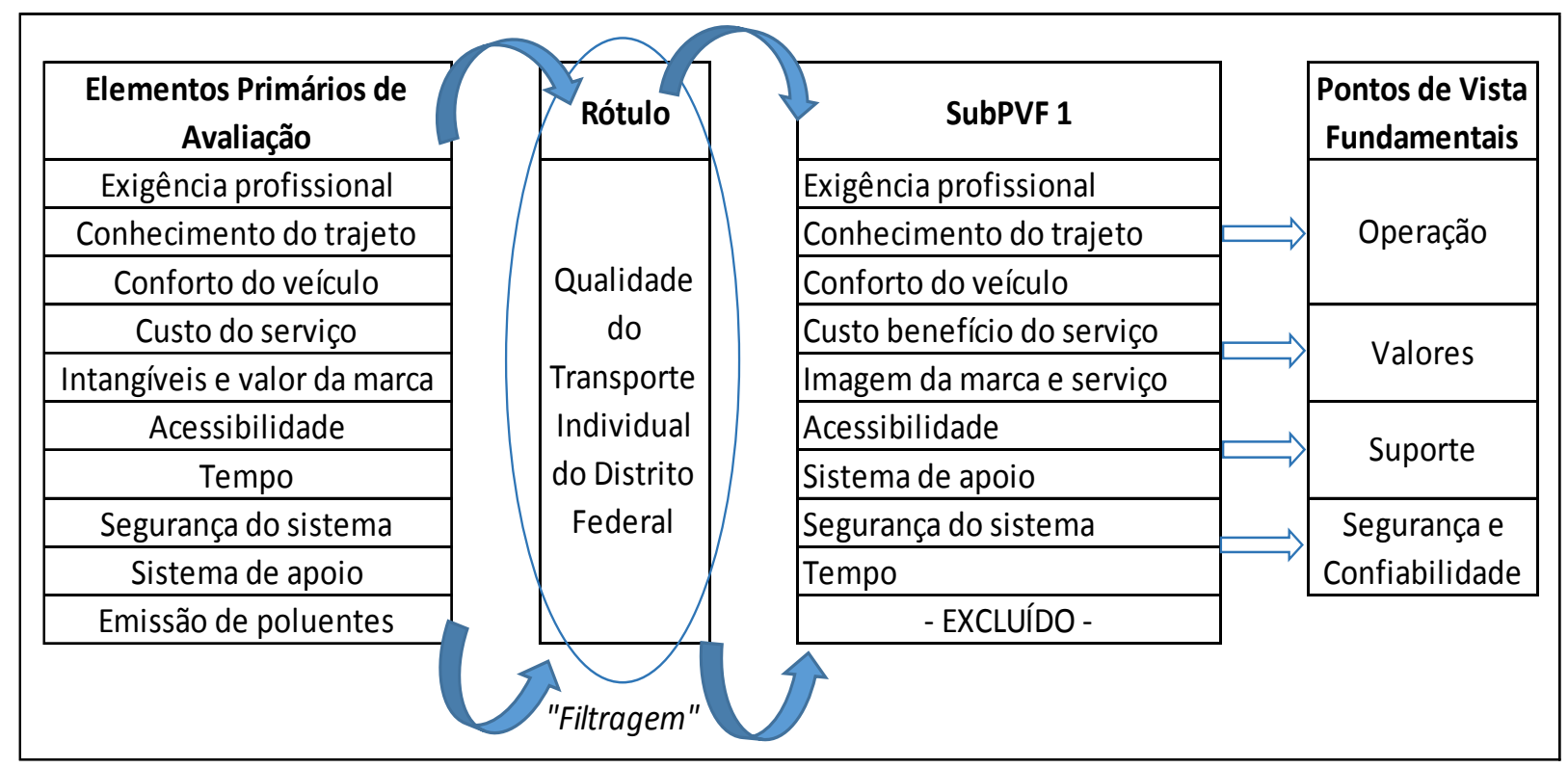

Figura 4.2: "Filtragem de ideias"

Para a definição dos PVF foi necessário buscar a relação direta entre cada EPAs com o detalhamento do rótulo da pesquisa, a fim de buscar a sua aderência, baseada nos conceitos significativos e importantes para a percepção da "Qualidade do Transporte Individual no Distrito Federal”.

Após identificados os PVF, foi construída a árvore de valor, demonstrando os vínculos e transferência no sentido de baixo para cima até chegar ao rótulo da pesquisa, conforme demonstrado na Figura 4.3 abaixo. 


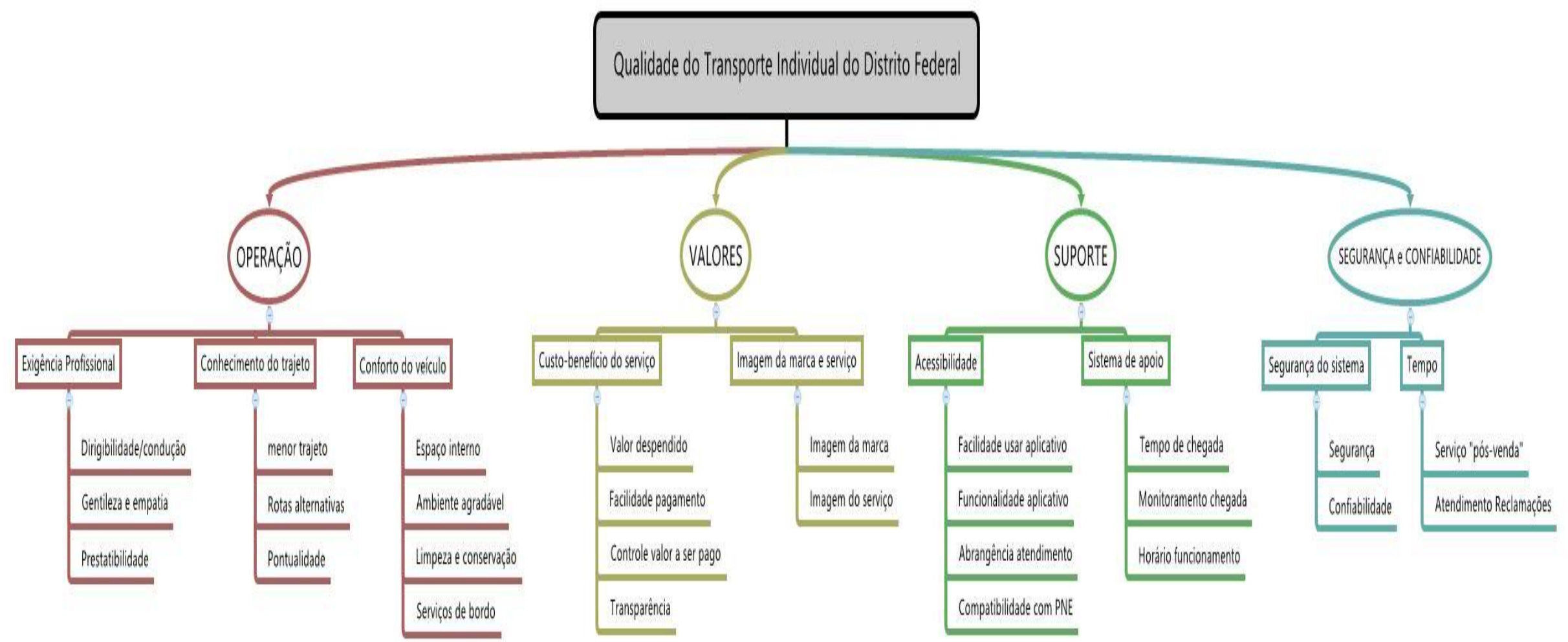

Figura 4.3: árvore de valor 
Após concluída a montagem da árvore de valor, foi realizada a atribuição de pesos para cada elemento de seu conjunto, sendo que o somatório de cada conjunto foi de 100\%, até chegar ao primeiro nível dos critérios (Formulário utilizado no brainstorming no Apêndice A). O Quadro 4.2, a seguir, demonstra quais foram os pesos (taxas de substituição) atribuídos pelos decisores para cada Subcritério.

Quadro 4.2 - Homologação dos PVF e taxa de substituição pelos decisores.

\begin{tabular}{|c|c|c|}
\hline PVF & SubPVF & SUBPVF \\
\hline (Critério) & (Subcritério1) & (Subcritério2) \\
\hline \multirow{13}{*}{$\begin{array}{l}\text { OPERAÇÃO } \\
(25 \%)\end{array}$} & \multirow{5}{*}{ 1. Exigência profissional (40\%) } & 1.1. Dirigibilidade / Condução do veículo (30\%) \\
\hline & & 1.2. Gentileza e Empatia no trato verbal $(20 \%)$ \\
\hline & & 1.3. Prestatividade para ações físicas (20\%) \\
\hline & & 1.4. Higiene pessoal $(20 \%)$ \\
\hline & & 1.5. Acesso à segunda língua $(10 \%)$ \\
\hline & \multirow{3}{*}{ 2. Conhecimento do trajeto $(40 \%)$} & 2.1. Sugestão de trajetos possíveis $(30 \%)$ \\
\hline & & $\begin{array}{l}\text { 2.2. Proatividade para solucionar problemas de tráfego } \\
\text { rotas alternativas }(20 \%)\end{array}$ \\
\hline & & 2.3. Pontualidade para chegar ao destino $(50 \%)$ \\
\hline & \multirow{5}{*}{ 3. Conforto do Veículo (20\%) } & 3.1. Espaço interno adequado. $(20 \%)$ \\
\hline & & 3.2. Ambiente agradável. (30\%) \\
\hline & & 3.3. Limpeza e conservação. (30\%) \\
\hline & & 3.4. Serviço de bordo adicionais. $(10 \%)$ \\
\hline & & 3.5. Espaço do porta-malas $(10 \%)$ \\
\hline \multirow{6}{*}{$\begin{array}{l}\text { VALORES } \\
(35 \%)\end{array}$} & \multirow{4}{*}{$\begin{array}{l}\text { 4. Custo x benefício do serviço } \\
(80 \%)\end{array}$} & 4.1. Preço do serviço. $(50 \%)$ \\
\hline & & 4.2. Facilidade (formas) de pagamento $(20 \%)$ \\
\hline & & 4.3. Controle do valor a ser pago na corrida. $(15 \%)$ \\
\hline & & 4.4. Transparência da forma de cálculo da tarifa. (15\%) \\
\hline & \multirow{2}{*}{$\begin{array}{l}\text { 5. Intangíveis e valor da marca } \\
(20 \%)\end{array}$} & 5.1. Imagem da marca - táxi ou uber. $(30 \%)$ \\
\hline & & 5.2. Percepção de valor do serviço. $(70 \%)$ \\
\hline \multirow{6}{*}{$\begin{array}{l}\text { SUPORTE } \\
(20 \%)\end{array}$} & \multirow{3}{*}{$\begin{array}{l}\text { 6. Acessibilidade (Oferta de } \\
\text { serviço) }(40 \%)\end{array}$} & 6.1 Facilidade de gerar o pedido do serviço (40\%) \\
\hline & & 6.2 Abrangência de atendimento - Área $(50 \%)$ \\
\hline & & 6.3 Adaptação à Necessidades Especiais (10\%) \\
\hline & \multirow{3}{*}{ 7. Tempo $(60 \%)$} & 7.1 Tempo de chegada após pedido $(40 \%)$ \\
\hline & & 7.2 Monitoramento da chegada $(20 \%)$ \\
\hline & & 7.3 Horário de funcionamento $(40 \%)$ \\
\hline \multirow{6}{*}{$\begin{array}{l}\text { SEGURANÇA } \\
\text { ( } 20 \%)\end{array}$} & \multirow{4}{*}{$\begin{array}{l}\text { 8. Segurança e Confiabilidade } \\
(80 \%)\end{array}$} & 8.1 Sensação de segurança - identificação do serviço (30\%) \\
\hline & & 8.2 Itens de segurança do veículo (15\%) \\
\hline & & 8.3 Privacidade $(15 \%)$ \\
\hline & & 8.4 Confiabilidade - disponibilidade de serviço (40\%) \\
\hline & \multirow{2}{*}{ 9. Sistema de apoio $(20 \%)$} & 9.1. Serviço "pós-venda" - atendimento. $(40 \%)$ \\
\hline & & 9.2. Atendimento para reclamações. $(60 \%)$ \\
\hline
\end{tabular}

Os percentuais, ou taxas de substituição, contribuem para cada critério que está um nível acima, por exemplo, os SubPVF2 (1.1.1; 1.1.2 e 1.1.3) contribuem para o SubPVF1 (1.1) que, juntamente com o SubPVF1 (1.2), contribuem para o PVF (1. OPERAÇÃO). 


\subsubsection{TIPO DE AVALIAÇÃO A SER FEITA ATRAVÉS DO MODELO}

Rodrigues (2014) afirma que a decomposição dos Pontos de Vista Fundamentais (Critérios) em Sub Pontos de Vista Fundamentais (Subcritérios) viabiliza o processo de identificação das ações potenciais para se chegar aos fins com maior sucesso.

Segue abaixo o tipo de avaliação (conceituação de cada PVF) que se pretende buscar através do modelo:

a) Operação: Capacidade de conduzir o veículo de forma orientada para um desempenho eficiente, com boa técnica, prudência, habilidade, agilidade e pontualidade. Inclui neste quesito o bom trato com o usuário do serviço de transporte individual, de acordo com os bons costumes e prestatividade para ações físicas que demonstrem proatividade e gentileza. Sem, contudo, esquecer da sua boa apresentação pessoal e capacitação para a atividade laboral em relação aos potenciais clientes. As condições operacionais e de conservação do veículo também figuram como quesitos importantes;

b) Valores: Tratam de questões relacionadas ao custo x benefício acerca da utilização do serviço, às condições e facilidade de pagamento, transparência e controle disponíveis ao usuário. Também estão contemplados neste quesito o que a marca representa para o usuário e qual é o valor que ele conceitua para o serviço;

c) Suporte: São considerados aqui os itens que facilitam o acesso dos usuários ao sistema de transporte individual, seja por abrangência do atendimento ou por necessidade de adaptação à diversidades. O monitoramento do tempo e horário de atendimento também contou para este item, vista a necessidade de prover suporte adequado aos clientes.

d) Segurança: São relevantes para este quesito aqueles itens que podem trazer sensação de segurança aos usuários, tanto física quanto psíquica. Além disso, integra a segurança a possibilidade de acesso a serviços pós-venda e reclamações, pois também agregam para o sentimento de segurança do usuário quanto à prestação do serviço.

\subsection{DESCRITORES PARA CONSTRUÇÃO DOS CRITÉRIOS}

Segundo Marafon et al. (2013), os descritores são instrumentos de gestão utilizados para medir alguma propriedade do contexto. Constituem-se de escalas ordinais, com níveis de impacto, que permitem mensurar o desempenho de cada ponto de vista, possuindo dois níveis de 
referência em suas extremidades, chamados de âncoras. São eles que permitem mensurar a performance de cada ação avaliada (quantificação).

Após definidos os PVF e SubPVF, foram classificados os descritores que representam melhor o desempenho do critério a ser analisado, do mais atrativo para o menos atrativo (Figura 4.4).

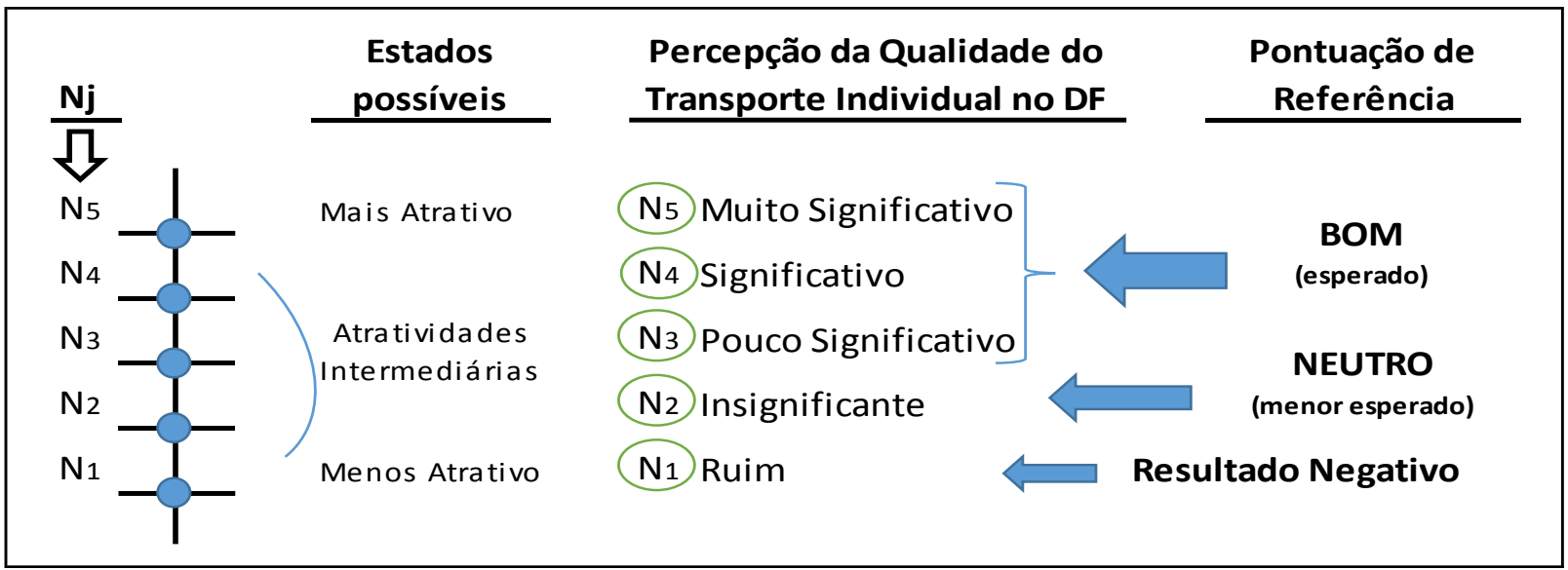

Figura 4.4: Estados do descritor em função do nível de atratividade

Segundo Quirino (2002), a hierarquização dos níveis de impacto dos descritores representa o grau de atratividade que cada nível de impacto tem numericamente. Os descritores se caracterizam por definirem o nível de impacto de cada questionamento dirigido ao usuário para construção do instrumento de coleta de dados. Cada estado possível do descritor corresponde a um nível de impacto "Nj”, sendo o “j” a representação crescente da preferência do decisor, onde $\mathrm{j}=1$ quando se relaciona ao menor nível de atratividade.

São divididos em cinco níveis: $\mathrm{N}_{1}$ - Nível de impacto negativo, o qual indica que o desempenho do sistema avaliado é negativo; $\mathrm{N}_{2}$ - Nível de impacto neutro, significa que o resultado neutro ou indiferente; $\mathrm{N}_{3}$ - constitui o primeiro impacto positivo; $\mathrm{N}_{4}$ - é o segundo nível de impacto positivo; e $\mathrm{N}_{5}$ - é o terceiro, e melhor, nível positivo esperado.

Essa escala de níveis de impacto, ou de esforço, são traduzidas da seguinte forma nos questionários (Figura 4.5):

\begin{tabular}{|c|c|c|c|c|}
\hline \multirow[t]{2}{*}{ Itens } & Critérios de Usabilidade & \multicolumn{2}{|c|}{ Nível de atratividade } & $\begin{array}{c}\text { BOM } \\
\text { (esperado) }\end{array}$ \\
\hline & Pontuações/Níveis de Esforço & $\begin{array}{l}\mathrm{N} \\
4\end{array}$ & $\left.\begin{array}{l|l|}\mathrm{N} & \mathrm{N} \\
3\end{array}\right)$ & $\begin{array}{c}\text { (menor } \\
\text { esperado) } \\
\text { NEGATMVO }\end{array}$ \\
\hline
\end{tabular}

Figura 4.5: Níveis de impacto ou atratividade 
Realizada a classificação dos descritores em conformidade com o eixo de avaliação e com base no rótulo da pesquisa "Percepção de qualidade do transporte individual do Distrito Federal: Táxi e Uber", foram definidos os níveis de atratividade como: porque, sob o ponto de vista cognitivo do respondente, essa classificação estaria no mesmo patamar do "Bom", que significa o nível imediatamente superior ao "Indiferente".

Para o presente modelo multicritério de apoio à decisão utiliza-se o paradigma construtivista baseado em multirespostas. Segundo Ensslin et al (2001), a escolha do paradigma é feita de acordo com os valores dos facilitadores e especialistas, pois não há como determinar se um paradigma é melhor do que o outro, haja vista que todos os decisores detêm o mesmo nível de conhecimento e perseguem os mesmos objetivos racionais. As decisões são tomadas por meio de diversas interações entre as preferências dos atores envolvidos (subjetividade).

Também por esse motivo são utilizados mais de um nível de impacto positivo (total de 3) ao invés de apenas um ponto único ideal, como é o caso de trabalhos com modelos de tomada de decisão, que utilizam a pesquisa operacional tradicional, sob o paradigma racionalista, o qual compreende a existência de um único problema a ser resolvido.

A partir da definição do nível de impacto dos descritores foi realizada a adaptação necessária ao questionário que seria submetido aos usuários para que pudesse facilitar o entendimento de acordo com os objetivos propostos pela pesquisa. Nesse momento, os PVF e SubPVF passam a ser chamados de Critérios e Subcritérios, respectivamente. Constam no Apêndice os questionários aplicados, com todas as questões que foram originadas e discutidas no brainstorming.

\subsection{APLICAÇÃO DOS QUESTIONÁRIOS}

Foram confeccionados 2 (dois) questionários para avaliar cada tipo de serviço de transporte individual de passageiros, um para usuários do táxi e outro para usuários do Uber. Também foram disponibilizados dois meios para responder os questionários: via internet, através da ferramenta Google Forms (Apêndices D e E), e por questionário impresso, realizado pessoalmente junto aos respondentes, (Apêndice C). Os questionários foram aplicados no período de 11 de maio a 06 de junho de 2016.

Para melhor adequação do questionário ao seu objetivo, de aferição da percepção por parte dos usuários, foram estabelecidos os seguintes critérios de aceitabilidade, de acordo com o 
delineado com os especialistas no brainstorming: quantidade mínima de 03 (três) utilizações do objeto avaliado e; idade mínima de 18 (anos) para os usuários participantes.

Segue abaixo, nos Quadros 4.3 e 4.4, o resumo da percepção dos usuários de táxi e Uber:

Quadro 4.3 - Resumo da percepção dos usuários sobre a qualidade do transporte individual de passageiros por táxi no DF

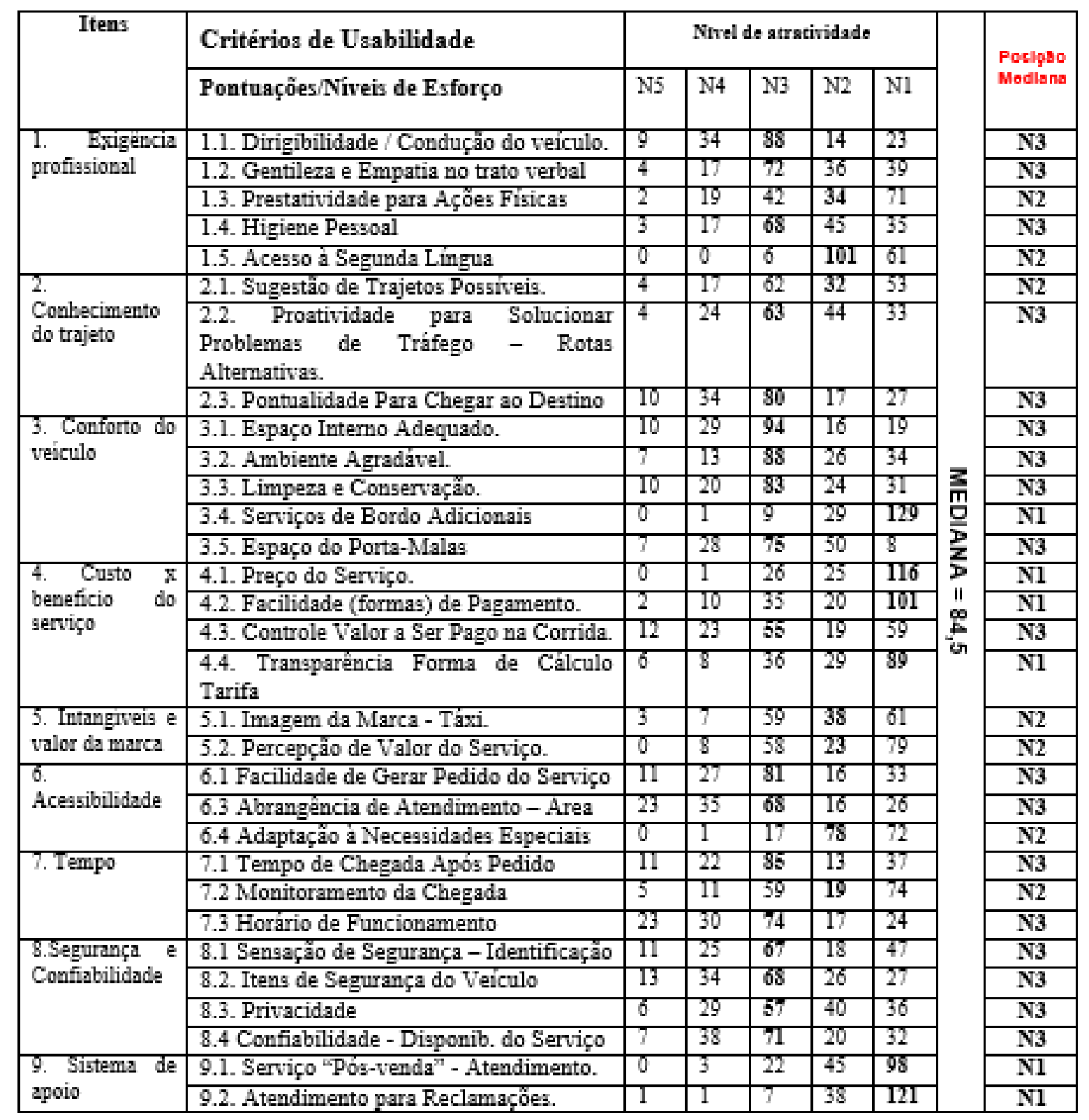

\section{(5) Excelente; (4) Muito Bom; (3) Bom; (2) Indiferente; (1) Ruim ou Serviço Inexiste.}

O valor descrito nos quadros como "MEDIANA" foi o resultado da divisão em dois grupos do total de questionários válidos respondidos para cada tipo de serviço, táxi e Uber. Esse número 
serviu de base para encontrar o valor numérico base que separa a metade superior da amostra de dados.

Quadro 4.4 - Resumo da percepção dos usuários sobre a qualidade do transporte individual de passageiros por Uber no DF

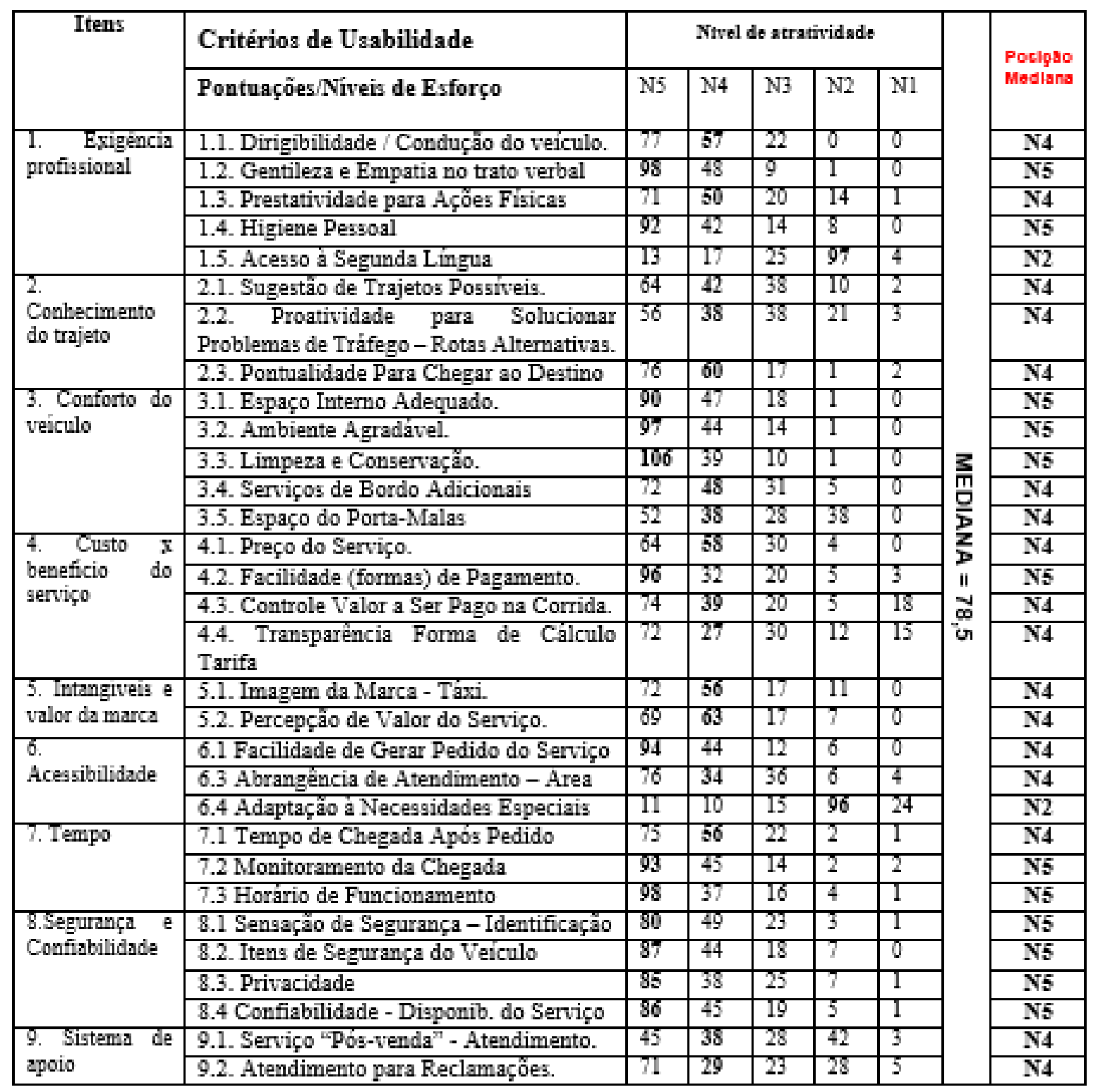

(5) Excelente; (4) Muito Bom; (3) Bom; (2) Indiferente; (1) Ruim ou Serviço Inexiste.

Etapa seguinte à tabulação dos dados extraídos da aplicação dos questionários, foi realizada a identificação da concentração (mediana) das respostas dos usuários participantes e colocada em destaque. Conforme o modelo de análise multicritério, a mediana é o ponto mais adequado para a identificação da concentração das percepções dos respondentes. 


\subsection{APLICAÇÃO DO SOFTWARE DE MODELAGEM COM BASE NO MCDA-C}

O presente trabalho tem como base as percepções fundamentais dos decisores sobre transporte individual de passageiros tendo como foco o elemento interveniente "usuário" e sua avaliação acerca de cada quesito definido pelos decisores. As avaliações (qualitativas) dos usuários, coletadas por meio da aplicação dos questionários, são inseridas no software MAMADecisão e transformadas em quantitativas.

Seguindo o passo-a-passo, após obtidos os resultados da aplicação dos questionários, esses dados foram tabulados e aplicados no software "MAMADecisão" de modelagem com base no MCDA-C. Foram inseridos, inicialmente, o rótulo da pesquisa, objetivo da pesquisa e objeto de estudo, bem como todos os nomes atribuídos a cada um dos níveis de avaliação (PVF, SubPVF1 e SubPVF2). Apresentamos como exemplos as Figuras 4.6 e 4.7, respectivamente, referentes ao serviço de táxi.

\section{Software MAMADECISÃO}

\section{(Modelagem para Análise Multicritério de Apoio à Decisão)}

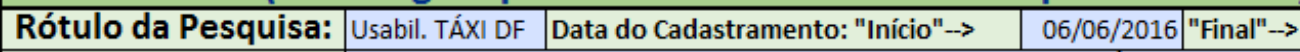
Objetivo da Pesquisa: Análise Comparativa das Usablidades do UBER e do TÁXI do DF \begin{tabular}{|l|l|l|l|l|l|l|l|}
\hline Objeto de Estudo Simplificado (6 dígitos): & USTAXI & Desempenhos: & Mázimo-s & Máx & Desempenho Real & Mínimo --> & Mín \\
\hline
\end{tabular}

Figura 4.6 - Inserção do rótulo da pesquisa no software

Importante destacar que nesse momento da pesquisa, inserção dos dados no software, os PVF e SubPVF passam a ser nomeados como Critérios e Subcritérios, respectivamente.

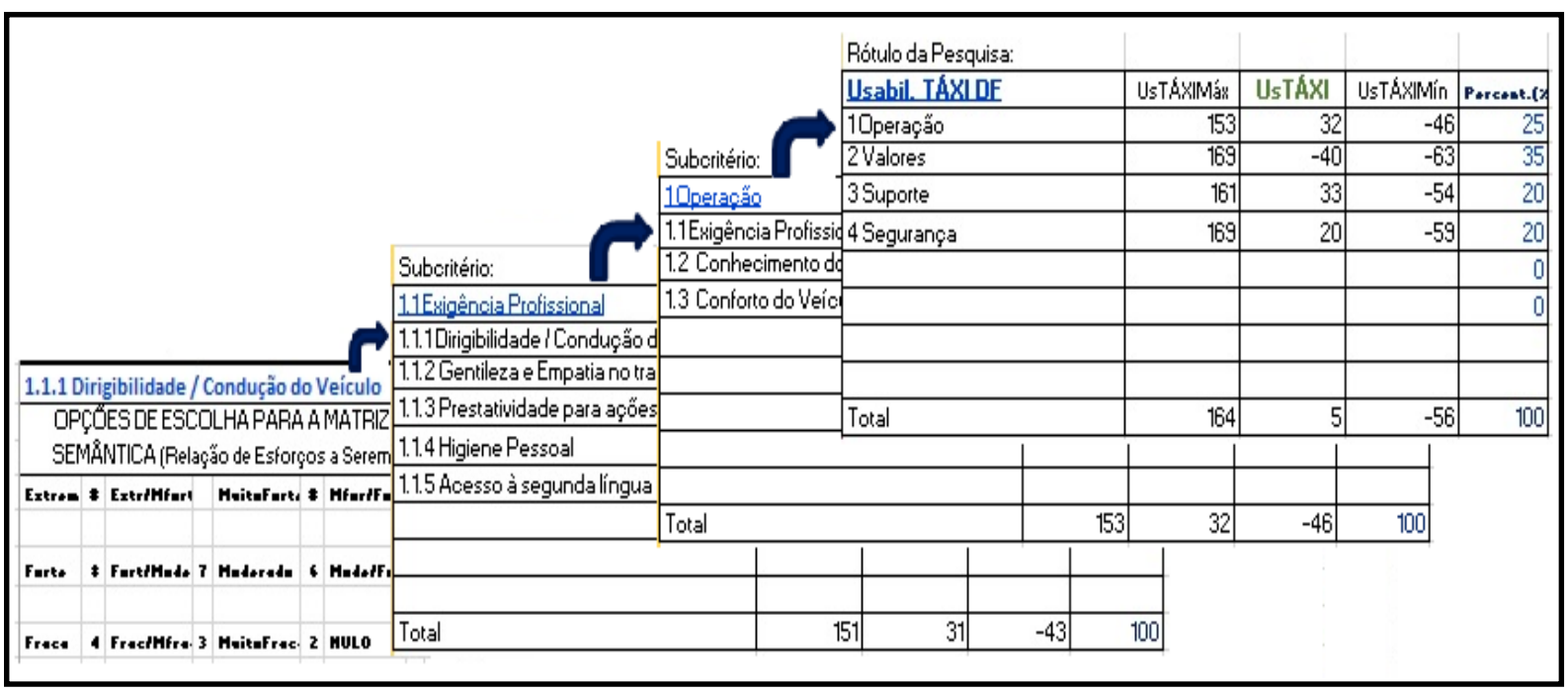

Figura 4.7 - Inserção dos nomes atribuídos a cada Critério (PVF) e Subcritérios (SubPVF). 
Posteriormente, foram inseridas as taxas de substituição de todos os níveis de avaliação (Critérios e Subcritérios), destacadas com a seta no exemplo descrito na Figura 4.8, para a geração das propriedades das questões avaliadas em níveis qualitativos de performance.

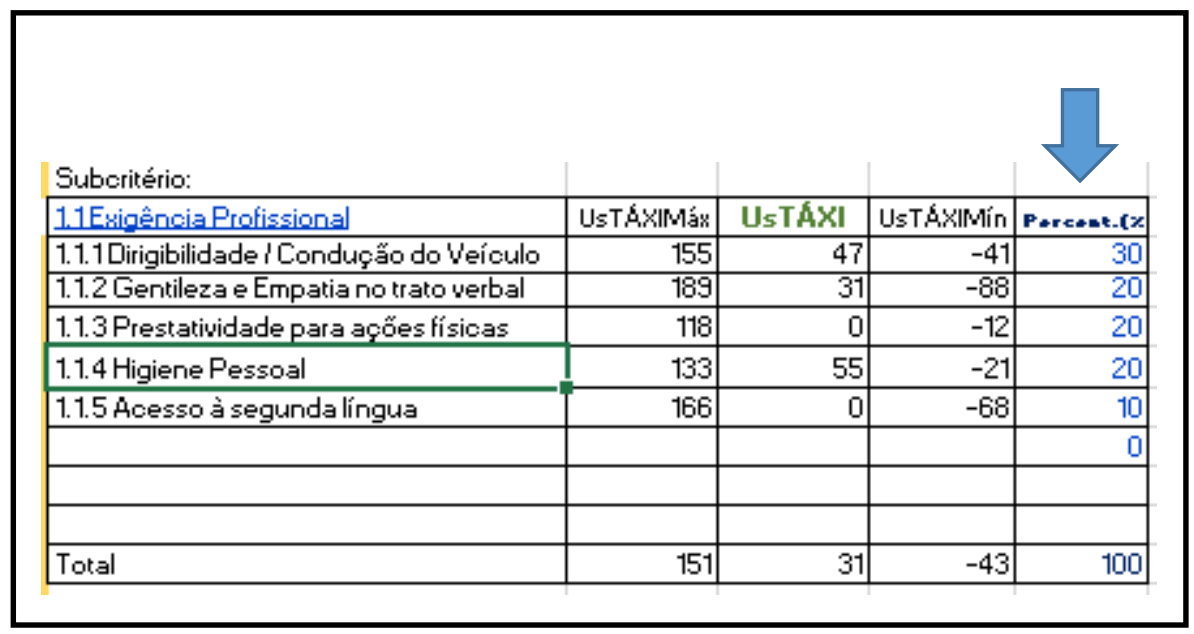

Figura 4.8 - Inserção das taxas de contribuição no MAMADecisão

Logo após, foram inseridas as posições das medianas encontradas na coleta das respostas dos questionários, representado por um " $x$ " no exemplo da Figura 4.9 (as medianas de todos os descritores podem ser encontradas nos Apêndices F e G)

\begin{tabular}{|c|c|c|c|c|}
\hline Dpçōes & Dpçōes & Nível & Marque & Escala \\
\hline Mediana & Modelo & Impact & Com->z & \\
\hline Ótimo & Excel & N5 & & 155 \\
\hline $\mathrm{BDM}$ & MBom & "N4" & & 100 \\
\hline Regular & Bom & N3 & $x$ & 47 \\
\hline NEUTRO & Indifere & "N2" & & 0 \\
\hline Negativo & Ruimlin & N1 & & -41 \\
\hline \multicolumn{3}{|c|}{ Posicáo da Hediana: } & $\sqrt{3}$ & 47 \\
\hline
\end{tabular}

Figura 4.9 - Exemplo de marcação da posição da mediana no software.

A etapa seguinte foi o ajuste das Matrizes Semânticas de acordo com os níveis de esforços para cada Subcritério (Figura 4.10), definidos e validados durante o brainstorming realizado com os especialistas na fase inicial do trabalho (formulário disponível no Apêndice B). Assim, por estruturação matemática, uma escala numérica entre os diferentes níveis de impacto é formada. 


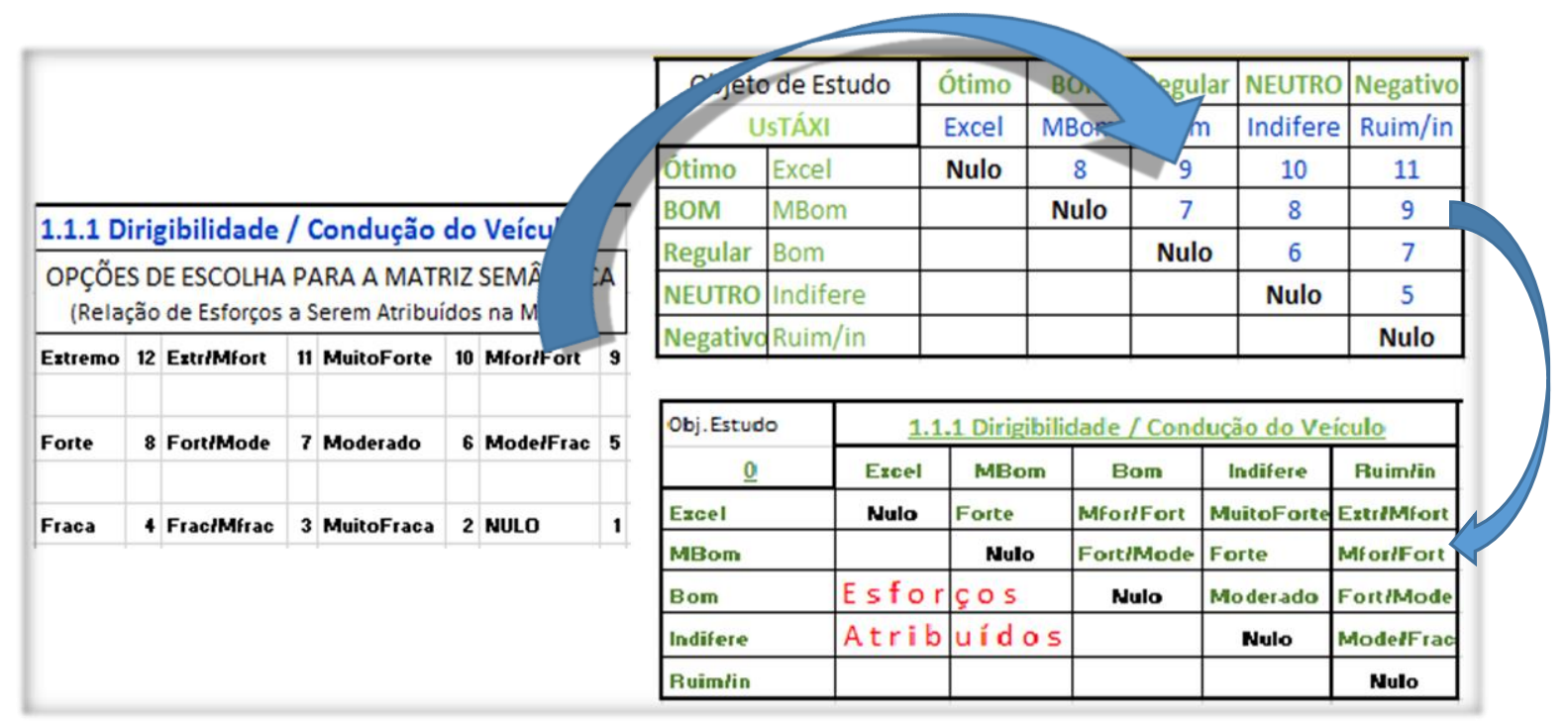

Figura 4.10 - Ajuste da Matriz Semântica (simétrica).

Feito isso, o software apresenta o desempenho do Subcritério que está sendo avaliado, considerando as taxas de substituição atribuídas a cada SubPVF, e que são calculadas no software por meio da média ponderada (essas taxas foram informadas no Quadro 4.2 deste trabalho). A Figura 4.11 ilustra como é apresentado esse desempenho para o subcritério "1.1 Exigência Profissional" para táxi.

\begin{tabular}{|c|c|c|c|c|c|c|c|}
\hline Subcritério: & & & & & & & \\
\hline 1.1 Exigência Profissional & UsTÁxIMáx & UsTÁXI & UsTÁXIMín & Percent.(\%) & Definição & \multirow{2}{*}{ Escala } & \multirow{2}{*}{ 1.1 Exigência Profissional } \\
\hline 1.1.1 Dirigibilidade / Condução do Veículo & 155 & 47 & -41 & 30 & Modelo & & \\
\hline 1.1.2 Gentileza e Empatia no trato verbal & 189 & 31 & -88 & 20 & Excel & 151 & \\
\hline 1.1.3 Prestatividade para açōes físicas & 118 & 0 & -12 & 20 & MBom & 100 & \\
\hline 1.1.4 Higiene Pessoal & 133 & 55 & -21 & 20 & Bom & 46 & \\
\hline \multirow[t]{2}{*}{ 1.1.5 Acesso à segunda língua } & 166 & 0 & -68 & 10 & Indifere & 0 & \\
\hline & & & & 0 & Ruim/in & -43 & 3 \\
\hline & & & & & & & \\
\hline Total & 151 & 31 & -43 & 100 & & & \\
\hline
\end{tabular}

Figura 4.11 - Cálculo do desempenho do Subcritério "1.1 Exigência Profissional” para táxi.

Após identificados todos os desempenhos de cada Subcritério, e consideradas suas respectivas taxas de substituição, os resultados são apresentados em gráficos, que são analisados no próximo capítulo. 


\section{ANÁLISE DA PERCEPÇÃO DOS SISTEMAS DE TRANSPORTE INDIVIDUAL DE PASSAGEIROS}

Este capítulo é dedicado à análise dos gráficos de avaliação da percepção dos sistemas de transporte individual de passageiros à luz do referencial teórico. Todos os resultados são interpretados e discutidos a seguir.

\subsection{INFORMAÇÕES SOCIOECONÔMICAS}

Foram incluídas no questionário as informações socioeconômicas dos usuários respondentes, tais como sexo, faixa etária, renda e nível de escolaridade. Algumas questões eram excludentes da pesquisa, tais como idade inferior a 18 anos e utilizações dos serviços inferiores a 3 vezes. Consideramos válidos 168 questionários para Táxi e 156 para Uber.

Além do fator limitante de 3 utilizações dos serviços, foi verificado que a maioria dos respondentes dos dois questionários havia utilizado mais do que 5 vezes os serviços avaliados. Foram $83,93 \%$ para táxi e $71,15 \%$ para Uber, colaborando para uma melhor percepção dos critérios avaliados.

Ambos os questionários foram amplamente divulgados por meio de redes sociais (Facebook e Whatsapp), grupos de e-mail, contatos pessoais e profissionais. Também foram realizadas pesquisas com questionários impressos e na mesma proporção para ambos os tipos de serviço avaliados (aproximadamente 1/3 de questionários impressos).

De forma resumida, as informações socioeconômicas que foram extraídas dos questionários respondidos constam no Quadro 5.1 abaixo:

Quadro 5.1 -Usuários de cada tipo de serviço, separados por sexo e faixas etárias

\begin{tabular}{|c|c|r|r|r|}
\hline & \multicolumn{2}{|c|}{ TÁXI } & \multicolumn{2}{c|}{ UBER } \\
\hline $\begin{array}{c}\text { Pesquisas } \\
\text { Válidas }\end{array}$ & \multicolumn{2}{|c|}{168} & \multicolumn{2}{c|}{156} \\
\hline \multirow{2}{*}{ Sexo } & Masculino & Feminino & Masculino & Feminino \\
\cline { 2 - 5 } & $50,60 \%$ & $49,40 \%$ & $48,10 \%$ & $51,90 \%$ \\
\hline \multirow{4}{*}{ Faixa } & 18 a 25 & $30,95 \%$ & 18 a 25 & $50,00 \%$ \\
Etária & 26 a 35 & $45,24 \%$ & 26 a 35 & $36,71 \%$ \\
& 36 a 45 & $17,26 \%$ & 36 a 45 & $10,76 \%$ \\
& 46 a 55 & $1,79 \%$ & 46 a 55 & $1,90 \%$ \\
& Mais de 55 & $4,76 \%$ & Mais de 55 & $0,63 \%$ \\
\hline
\end{tabular}


Constatamos que a principal variação entre os usuários de táxi e Uber se concentrou nas $1^{\mathrm{a}}$ e $2^{\mathrm{a}}$ faixas de idades, onde podemos identificar maior utilização do Uber em detrimento do táxi na faixa etária de "18 a 25 anos", cerca de $20 \%$, Tal situação se justifica pelo fato dessa geração ter mais acesso às redes sociais e propensão à utilização, em maior escala, de aplicativos de smartphones.

As faixas de renda foram estabelecidas de acordo com o critério do IBGE para definição de classes sociais. No Quadro 5.2 constam as faixas de renda identificadas na pesquisa.

Quadro 5.2 - Usuários divididos por faixas de renda

\begin{tabular}{|c|l|r|l|r|}
\hline & \multicolumn{2}{|c|}{ TÁXI } & \multicolumn{2}{c|}{ UBER } \\
\hline Faixas de & Até 2 & $1,19 \%$ & Até 2 & $4,43 \%$ \\
Renda & 2 a 4 & $8,93 \%$ & 2 a 4 & $16,46 \%$ \\
(Salários & 4 a 10 & $26,79 \%$ & 4 a 10 & $25,95 \%$ \\
Mínimos) & 10 a 20 & $35,12 \%$ & 10 a 20 & $31,01 \%$ \\
\cline { 2 - 4 } & Mais de 20 & $27,98 \%$ & Mais de 20 & $22,15 \%$ \\
\hline
\end{tabular}

Em relação às faixas de renda dos respondentes, foi constatado uma maior incidência do Uber na faixa de renda de "2 a 4 Salários Mínimos" e, inclusive, um pequeno aumento também na faixa de menor renda "Até 2 Salários Mínimos".

Outra informação extraída dos questionários foi o grau de instrução dos respondentes, onde foi possível identificar, principalmente, que a maioria dos usuários possuíam o grau "Ensino Superior", e que houve uma pequena inversão nas utilizações de táxi e Uber entre detentores do grau "Ensino Médio" e "Mestrado". Os mestres utilizam mais o serviço de táxi na mesma proporção que os de ensino médio utilizam o Uber. O Quadro 5.3 ilustra melhor essa situação.

Quadro 5.3 - Usuários divididos por grau de escolaridade

\begin{tabular}{|l|r|r|}
\hline Grau de Instrução & \multicolumn{1}{|c|}{ TÁXI } & \multicolumn{1}{|c|}{ UBER } \\
\hline Fundamental & $0,00 \%$ & $0,00 \%$ \\
\hline Médio & $7,14 \%$ & $13,93 \%$ \\
\hline Superior & $44,05 \%$ & $52,53 \%$ \\
\hline Pós-Graduação & $33,33 \%$ & $24,05 \%$ \\
\hline Mestrado & $14,88 \%$ & $8,86 \%$ \\
\hline Doutorado & $0,60 \%$ & $0,63 \%$ \\
\hline
\end{tabular}

Por último, foi verificado que a grande maioria dos usuários de ambos os serviços possuíam facilidade para adquirir produtos ou contratar serviços pela plataforma web, porém, houve um 
percentual maior entre os respondentes da pesquisa sobre o Uber. Esse resultado ocorre devido a necessidade de manuseio do Uber para smartphones.

Quanto ao último item avaliado, sobre a utilização do serviço de rádio táxi, ambos respondentes do táxi e do Uber tiveram percentuais aproximados, entretanto, com uma leve diferença para menos daqueles usuários do Uber, ou seja, tiveram menor experiência com o serviço de rádio táxi. Segue o detalhamento no Quadro 5.4.

Quadro 5.4 - Percentual de usuários que dominam compras na web e que já utilizou rádio táxi

\begin{tabular}{|c|c|c|c|}
\hline & TÁXI & UBER \\
\hline Domina compras & SIM & $88,69 \%$ & $96,84 \%$ \\
\hline na Web? & NÃO & $11,31 \%$ & $3,16 \%$ \\
\hline Utilizou serviço & SIM & $88,10 \%$ & $81,65 \%$ \\
\hline de rádio táxi? & NÃO & $11,90 \%$ & $18,35 \%$ \\
\hline
\end{tabular}

\subsection{OPERAÇÃO}

O critério "Operação" refere-se àquelas atividades relacionadas às condições operacionais, trato com o cliente e operação do veículo. Dentro desse critério haviam três Subcritérios: "1.1 Exigência Profissional”, "1.2 Conhecimento do Trajeto" e "1.3 Conforto do Veículo".

Cada Subcritério foi composto por SubPVF2 que serviram de base para as questões (Quadro 4.2) e, suas médias de avaliação, compuseram os pontos do gráfico demonstrado na Figura 5.1.

De acordo com o gráfico, verificamos que será necessário empreender muito mais esforços para o táxi chegar ao nível máximo de percepção de qualidade do que o Uber, entretanto, para ambos, o Subcritério que empreende menor esforço para transitar de um nível pior avaliado para o melhor avaliado é o "1.3 Conforto do Veículo".

Chegamos a essa conclusão porque as distâncias entre os indicadores de usabilidade "UsTÁXIMín" e "UsTÁXIMáx" para esse subcritério são menores do que os outros subcritérios, então, um capital investido nele, tem potencial de gerar maiores resultados.

Verifica-se, por meio do gráfico, que o desempenho do Critério "1. Operação" do serviço de táxi é relativamente linear, porém, a satisfação dos usuários é baixa, pois está no patamar entre os níveis "Indiferente" e o "Bom". 
Para o serviço de Uber, o Subcritério "1. Operação" encontra-se quase no seu limite superior de usabilidade, sendo que o menor caminho para se melhorar o nível de usabilidade seria investir no Subcritério "1.3 Conforto do veículo", pois sua amplitude entre "UsUBERMín" e "UsUBERMáx” é a menor, gerando um menor esforço necessário para se chegar ao nível máximo de excelência.

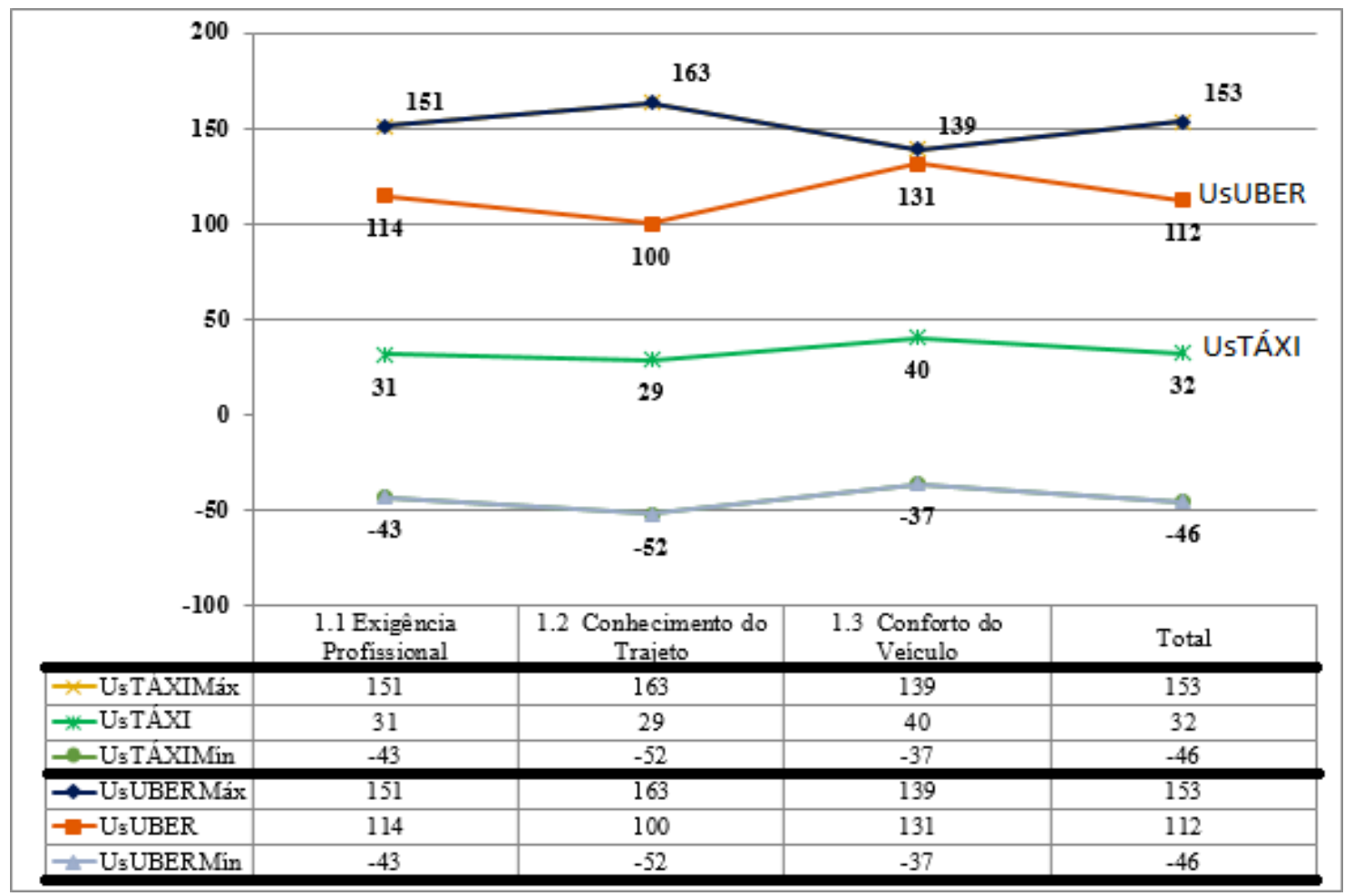

Figura 5.1 - Gráfico de desempenho do Critério “1. Operação” para os serviços de táxi e Uber

Conforme conceito de usabilidade para transporte, referido no tópico 3.3, este constitui-se da propriedade de ações que permite a interação do homem com o serviço e que viabiliza o objeto pretendido de maneira mais confortável, fácil, interativa e eficiente possível. É a relação que se estabelece entre usuário, tarefa, equipamento e ambiente, permitindo a adequação do ambiente do sistema de transportes às necessidades de quem o utiliza.

De acordo com a tríade de usabilidade, definida por Rodrigues (2014), o critério operação pode se enquadrar tanto na "Decisão" quanto na "Movimentação" do DAM. Como "Decisão" porque engloba itens que influenciam a escolha do meio de transporte pelo usuário, tais como a exigência profissional, conhecimento do trajeto pelo motorista e o conforto do veículo, e esses três subcritérios são elementos a serem avaliados pelos usuários em suas experiências para 
utilizações futuras do serviço. E se relacionam com "Movimentação" por propiciar o direito de ir e vir das pessoas, especialmente em relação ao conhecimento do trajeto pelo motorista.

\subsection{VALORES}

Este Subcritério possui relação com o custo $\mathrm{x}$ benefício acerca da utilização do serviço, as condições e facilidade de pagamento, e transparência e controle disponíveis ao usuário. Também estão atrelados a esse critério os valores agregados à marca e serviços prestados. A Figura 5.2, abaixo, ilustra o desempenho do critério "2. Valores" para os serviços de táxi e Uber.

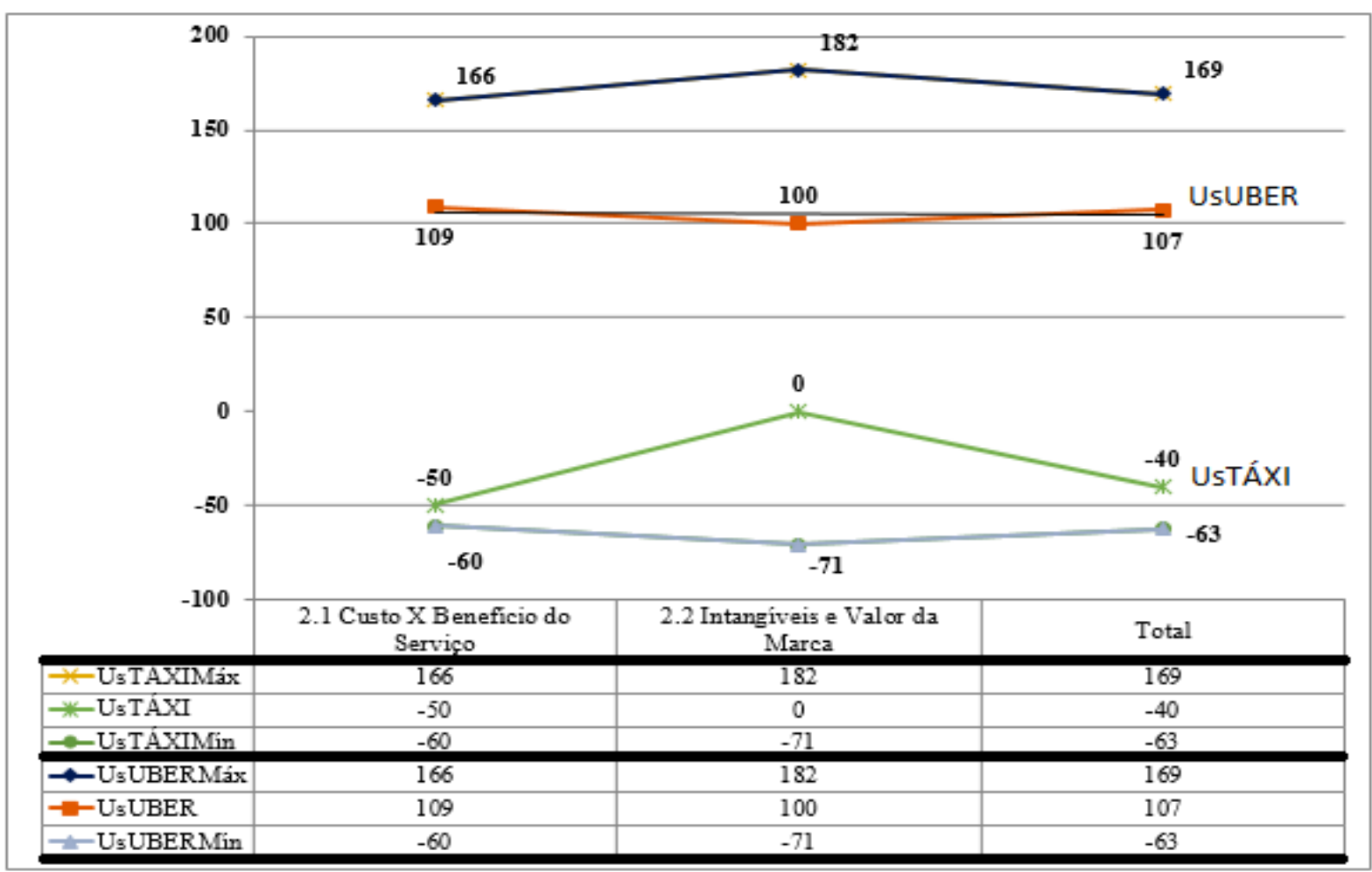

Figura 5.2 - Gráfico de desempenho do critério "2. Valores” para os serviços de táxi e Uber.

Verificamos que o serviço de táxi obteve avaliação ruim para este critério, tendo como melhor nível o "2.2 Intangíveis e Valor da Marca", que foi avaliado simplesmente como "Indiferente" pelos usuários de maneira geral. O Subcritério mais propício a ser investido foi o "2.1 Custo x Benefício do Serviço", visto que demanda menos esforço para mudar de nível de percepção de qualidade

Diferentemente do táxi, o critério foi bem avaliado para o serviço do Uber, prevalecendo no nível "Muito Bom". Para melhorar o nível de usabilidade, o critério mais propício (que exige 
menos esforço) também é o "2.1 Custo x Benefício do Serviço”, pois o caminho a ser percorrido até o nível máximo de satisfação é menor.

É possível perceber que, ao tempo em que o serviço prestado pelo Uber se aproxima da excelência, aquele prestado pelo táxi encontra-se entre o pior nível de avaliação e o nível neutro. O único Subcritério que se apresentou dentro da neutralidade para os táxis foi o "2.2 Intangíveis e Valor da Marca”, ou seja, este Subcritério, de maneira geral, causa uma reação indiferente entre os usuários ao utilizarem o serviço, talvez por não identificarem o serviço como uma marca ou devido a marca não refletir um status social.

Novamente em relação à usabilidade, o critério "Desempenho" se enquadra no "Acesso" e na "Decisão" da tríade DAM. Acesso em relação ao preço porque se o usuário não possuir condições financeiras suficientes para pagar pelo serviço isso o impedirá de utilizá-lo, porém, caso tenha condições e possa escolher, o valor do serviço poderá se tornar uma decisão em utilizar ou não o serviço. Outro aspecto que importa na decisão são os intangíveis e valor da marca, pois caso o usuário em potencial não tenha simpatia ou a marca não lhe agrade, seja por conceitos pré-formulados ou não, a decisão de utilizar o serviço caberá a ele.

Em relação ao subcritério "2.1 Custo x Benefício do Serviço" do serviço Uber, em relação às formas de pagamento disponíveis, cabe ressaltar que também se enquadra no conceito de “Acesso" a necessidade de o usuário possuir cartão de crédito para ter acesso ao serviço.

\subsection{SUPORTE}

São considerados aqui os itens que facilitam o acesso dos usuários ao sistema de transporte individual, seja por abrangência do atendimento ou por necessidade de adaptação a diversidades. O monitoramento do tempo e horário de atendimento também contaram para este item, visto a necessidade de prover suporte adequado aos clientes.

Na Figura 5.3 a seguir, é possível perceber, de maneira geral, que os usuários do táxi não se surpreendem com a qualidade do serviço em relação a esse Critério avaliado, pois encontra-se entre o nível "Indiferente" e "Bom", demonstrando que está dentro dos parâmetros esperados pelos gestores, porém, possui bastante espaço para melhoras.

Podemos dizer que o esforço para alterar a percepção de qualidade dos usuários de táxi, sobre os dois Subcritérios avaliados, é bem próximo. Porém, caso tenha que optar, o gestor poderá 
investir mais em "3.1 Acessibilidade”, de maneira a otimizar a acessibilidade ao usuário, pois exigirá menor esforço para a melhora do nível de serviço, visto que o nível "Bom” seria atingido com 40 pontos (apenas mais 4 pontos em relação ao atual nível). Já em relação ao Subcritério “3.2 Tempo”, seriam necessários mais 10 pontos para atingir o nível "Bom”. Na Figura 5.6 é possível identificar os pontos limítrofes dos níveis para cada Subcritério.

Já a percepção dos usuários do Uber acerca dos serviços prestados em relação ao Critério "3.1 Suporte" está localizada no nível de serviço "Muito Bom”, sendo que o Subcritério "3.2 Tempo" está bem próximo à excelência. Neste caso, apesar de pouca diferença, é demandado menos esforço para alterar o nível do Subcritério "3.2 Tempo", visto que a distância entre os pontos mínimo (UsUBERMín) e máximo (UsUBERMáx) é menor em relação do "3.1 Acessibilidade".

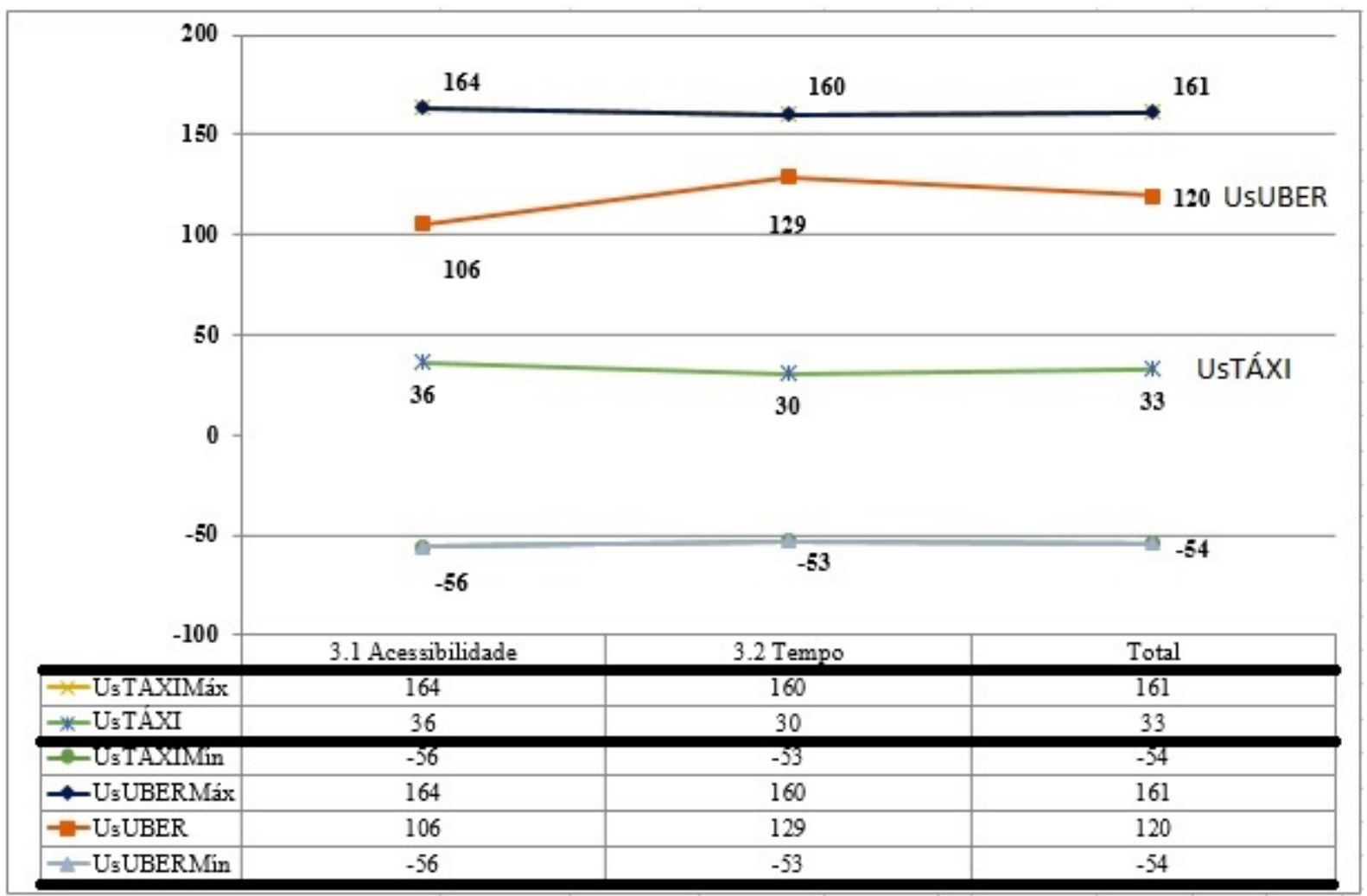

Figura 5.3 - Gráfico de desempenho do critério "3. Suporte" para os serviços de táxi e Uber.

O critério "3. Suporte", que incluiu acessibilidade e tempo, está enquadrado em "Acesso" e "Movimentação" do DAM, visto que são avaliados a facilidade de gerar o pedido do serviço, a abrangência do serviço, a adaptação do serviço às necessidades dos usuários, o horário de funcionamento, o monitoramento e tempo de chegada do serviço. 


\subsection{SEGURANÇA}

São aqueles itens que podem trazer sensação de segurança aos usuários, tanto física quanto psíquica. Integram a segurança a possibilidade de acesso a serviços pós-venda e a serviços de reclamação.

O gráfico abaixo (Figura 5.4) mostra que a percepção do serviço de táxi em relação ao Subcritério "4.1 Segurança e Confiabilidade" está no nível "Bom”, porém há bastante espaço para melhorar. Quanto ao outro Subcritério "4.2 Sistema de Apoio" a percepção foi a pior possível, demonstrando a necessidade de investir neste item.

Verificamos que os esforços despendidos para mudança de nível de serviço entre os Subcritérios é o mesmo, porém, é mais vantajoso para o gestor do serviço de táxi investir no "4.2 Sistema de Apoio" para sair da pior avaliação, mesmo porque a diferença entre a atual situação e o ponto neutro é de 59 pontos, enquanto que o Subcritério "4.1 Segurança e Confiabilidade", apesar de pouco satisfatório, já encontra-se no ponto limítrofe do "Bom" (40 pontos).

Em relação aos dois quesitos avaliados sobre o serviço Uber, o Subcritério "4.1 Segurança e Confiabilidade" apresentou o nível de avaliação máximo e o "4.2 Sistema de Apoio" localizouse no ponto limítrofe entre o "Bom" e o "Muito Bom". Assim, só haveria possibilidade de melhora do nível de serviço para o segundo Subcritério.

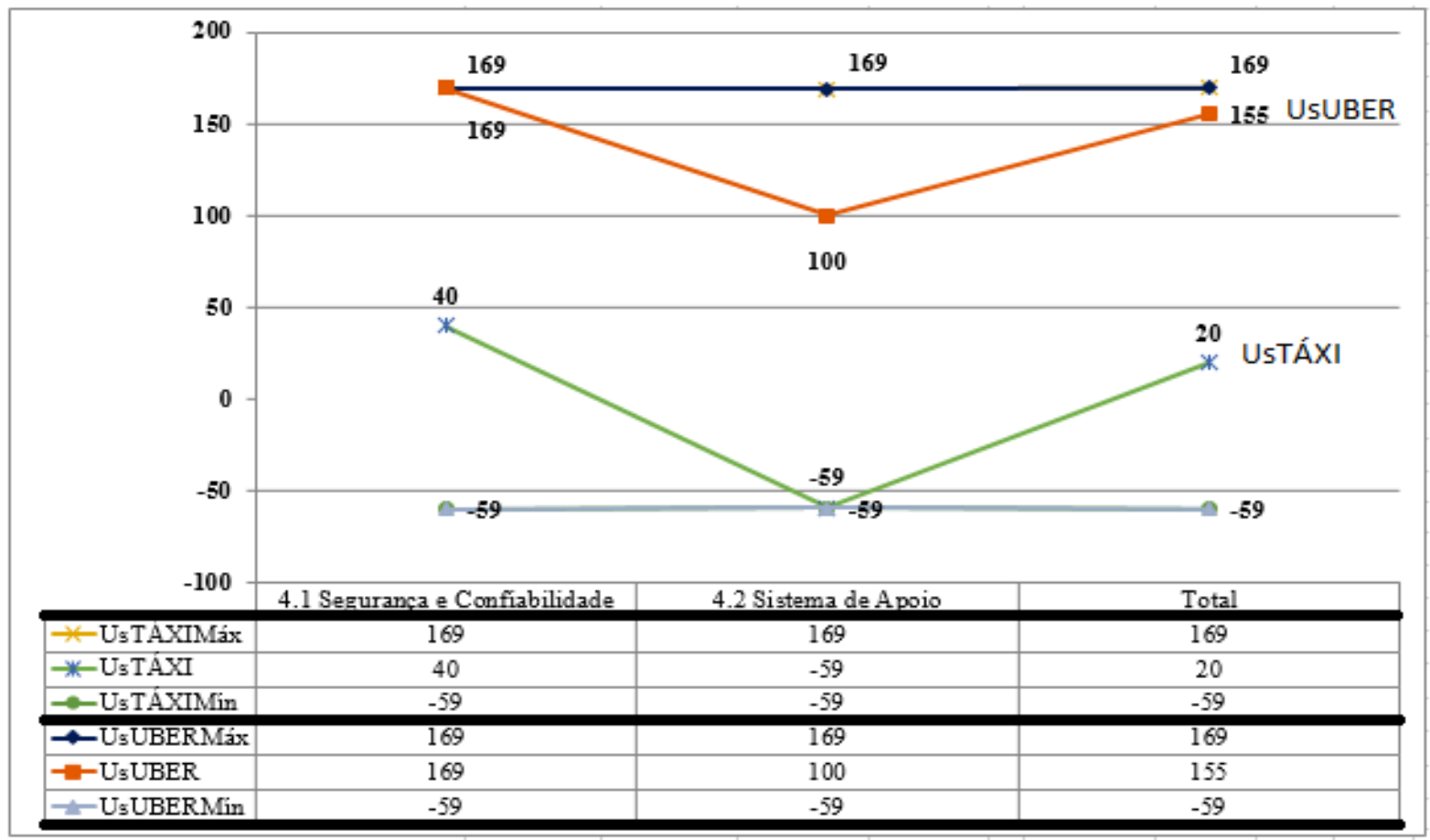


Figura 5.4 - Gráfico de desempenho do critério "4. Segurança” para os serviços de táxi e Uber. No gráfico é possível verificar uma grande diferença entre a percepção de qualidade pelos usuários em relação aos dois serviços. O Subcritério "4.1 Segurança e Confiabilidade" está avaliado no nível máximo para o Uber, enquanto para o táxi ele está apenas dentro do primeiro nível satisfatório. Para investimento em possíveis melhoras, sugere-se ambos investirem no Subcritério "4.2 Sistema de apoio", pois para o serviço de táxi ele foi avaliado no pior nível possível e para o Uber ele é o único capaz de trazer melhoras em relação à percepção.

Na usabilidade, a segurança se enquadra como "Decisão" do DAM, pois ela é fator essencial na decisão do usuário em utilizar o serviço. Em relação ao serviço de pós venda ou atendimento para reclamações pode se considerar também como "Decisão", pois caso o usuário se sinta mal atendido e seu problema não seja solucionado ele poderá optar por não utilizar mais o serviço

\subsection{COMPARAÇÃO DO DESEMPENHO GERAL DOS SISTEMAS DE TRANSPORTE INDIVIDUAL DE PASSAGEIROS NO DF: TÁXI E UBER}

A demonstração, em um só gráfico (Figura 5.5), do desempenho dos 04 (quatro) critérios (1. Operação; 2. Valores; 3. Suporte e; 4. Segurança) avaliados, permite a visualização de que a percepção dos serviços de táxi do Distrito Federal está próxima aos níveis de satisfação mínima em 03 (três), e em 01 (um) está situada no nível negativo de avaliação, ao passo em que os serviços do Uber estão todos compreendidos entre os dois melhores níveis de serviço da escala.

O Critério relativamente mais bem avaliado do táxi foi "3.Suporte", com 32 pontos (em uma amplitude de 199 pontos), e o mais bem avaliado do serviço Uber foi “4. Segurança”, com 155 pontos (em uma amplitude de 228). Porém, todos Critérios do serviço de táxi são inferiores àqueles do Uber.

Ressaltamos que essa avaliação é relativa, visto que, para o processo de tomada de decisão, é necessário levar em conta a amplitude entre os pontos mínimo e máximo, para identificar qual é o menor caminho a ser trilhado (menor esforço) para se obter melhores resultados.

Por fim, verificamos que o Critério “4. Operação” é o que demanda menos esforço para alterar seu status, devido à sua menor amplitude entre os pontos mínimo e máximo. 


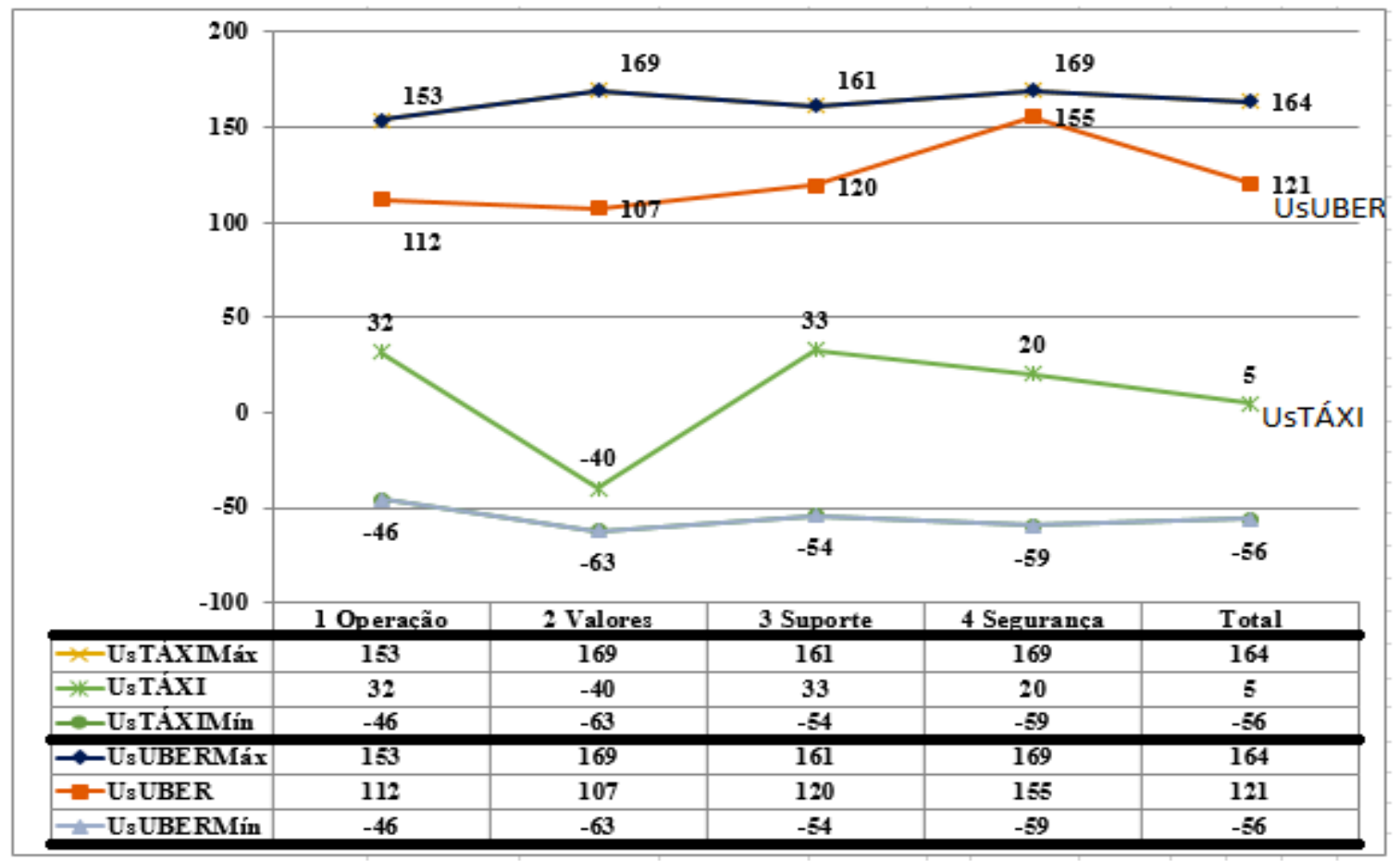

Figura 5.5 - Gráfico de usabilidade dos Serviços de táxi e Uber.

Outra forma de visualizar as médias dos níveis de serviço avaliados para cada Critério pode ser obtida através do quadro resumo reproduzido pelo Software do MCDA-C, cujos desempenhos finais dos Sistemas de Transporte Individual de Passageiros estão em destaque. (Figura 5.6).

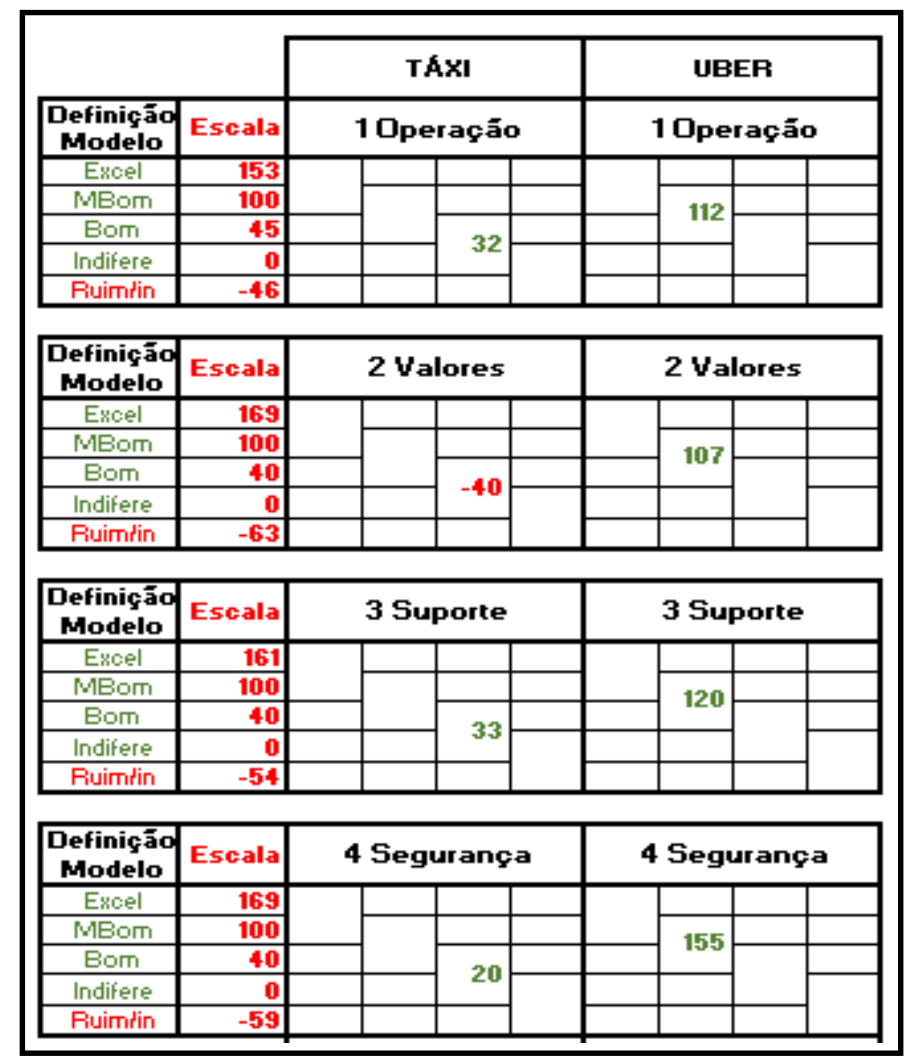

Figura 5.6 - Desempenho médio final para cada Critério avaliado 
A partir do desempenho médio final dos serviços de transporte individual no Distrito Federal, táxi e Uber, e considerando o conceito de tríade de usabilidade no transporte, temos que o serviço prestado pelo Uber encontra-se, em todos os critérios de avaliação, com classificação superior à do serviço de táxi.

Considerando o desempenho final dos dois serviços, e levando em consideração a escala final, que possui como desempenho mínimo -56 pontos e máximo de 164 pontos, o desempenho do serviço de táxi foi de 5 pontos, situando-se no primeiro nível positivo aceitável, enquanto o serviço Uber foi avaliado com 121 pontos, no segundo nível positivo aceitável e próximo ao maior nível (Figura 5.7).

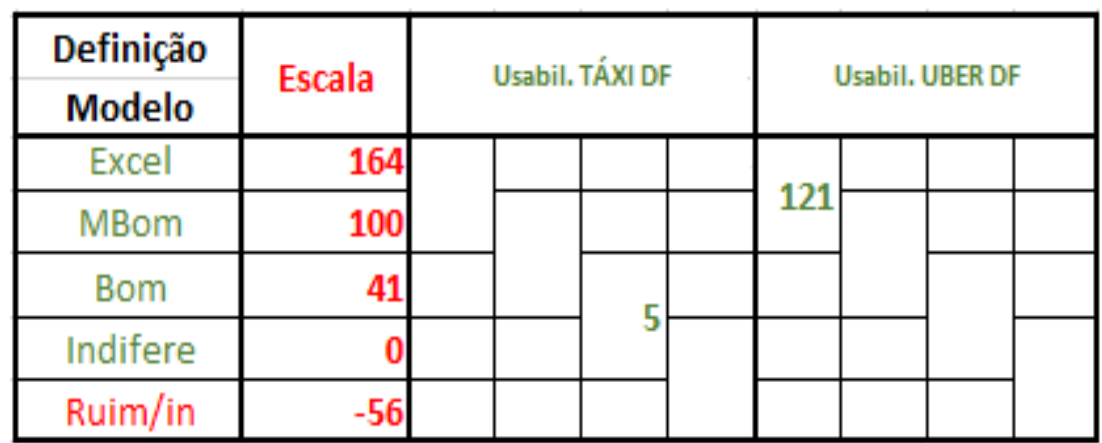

Figura 5.7 - Desempenho médio final dos Sistemas de Transporte Individual de Passageiros do DF: táxi e Uber, respectivamente.

Apesar do desempenho do serviço de táxi se enquadrar como aceitável, dentro da metodologia aplicada, ele ficou muito aquém daquele percebido pelos usuários do Uber, o que indica que os critérios de avaliação conseguiram atender melhor às expectativas e percepção dos usuários do Uber do que do táxi no Distrito Federal. 


\section{CONCLUSÃO}

O quadro a seguir (Quadro 6.1) apresenta um comparativo entre os objetivos específicos definidos no início da pesquisa e os resultados obtidos, a fim de cumprir o objetivo final de avaliar a percepção de qualidade do serviço de transporte individual de passageiros no Distrito Federal por meio da análise multicritério de apoio à decisão construtivista.

Quadro 6.1 - Comparativo entre objetivos e resultados da pesquisa.

\begin{tabular}{|c|c|}
\hline OBJETIVOS & RESULTADOS \\
\hline $\begin{array}{l}\text { i) Caracterizar os serviços de transporte } \\
\text { individual de passageiros: público (táxi) e } \\
\text { privado (Uber) a partir de pesquisa na } \\
\text { literatura e legislação; }\end{array}$ & $\begin{array}{l}\text { Foi realizada a diferenciação entre o conceito } \\
\text { de público e privado para transporte } \\
\text { individual, posteriormente, foram trazidos } \\
\text { conceitos acerca do transporte e feita uma } \\
\text { pesquisa acerca da prestação dos serviços de } \\
\text { táxi e Uber no Distrito Federal, origem, e } \\
\text { suas características. }\end{array}$ \\
\hline $\begin{array}{l}\text { ii) Diagnosticar os sistemas de transporte } \\
\text { individual público e privado do } \mathrm{DF} \text {; }\end{array}$ & $\begin{array}{l}\text { Houve pesquisa documental acerca das } \\
\text { origens dos dois serviços no Distrito Federal, } \\
\text { bem como identificada o funcionamento de } \\
\text { sua prestação. }\end{array}$ \\
\hline $\begin{array}{l}\text { iii) Conceituar qualidade e usabilidade e } \\
\text { estabelecer parâmetros, de acordo com } \\
\text { critérios definidos pelos gestores e } \\
\text { especialistas da área, para identificar a } \\
\text { qualidade dos serviços prestados nos dois } \\
\text { sistemas de transporte, sob o ponto de vista } \\
\text { dos usuários; }\end{array}$ & $\begin{array}{l}\text { Após conceituar qualidade e usabilidade, } \\
\text { foram estabelecidos parâmetros de coleta de } \\
\text { dados, de acordo os critérios definidos pelos } \\
\text { especialistas durante o brainstorming. Foram } \\
\text { utilizadas as mesmas ferramentas para ambos } \\
\text { os questionários de coleta de dados, foram } \\
\text { realizadas no mesmo período e mesmas } \\
\text { localidades. }\end{array}$ \\
\hline $\begin{array}{l}\text { iv) Comparar as percepções dos usuários } \\
\text { sobre os serviços de táxi e do Uber. }\end{array}$ & $\begin{array}{l}\text { Após aplicação dos questionários, elaborados } \\
\text { de acordo com o método MCDA-C, foram } \\
\text { identificadas as percepções e, por meio da } \\
\text { utilização do software, essas percepções } \\
\text { foram interpretadas de acordo com o método } \\
\text { e relacionadas com o referencial teórico. }\end{array}$ \\
\hline
\end{tabular}


Esta pesquisa teve por objetivo a avaliação da percepção da qualidade do serviço de transporte individual de passageiros no Distrito Federal em relação táxi e ao Uber e foi utilizada a metodologia Multicritério de Apoio à Decisão - Construtivista (MCDA-C).

Os resultados encontrados na aplicação do modelo mostraram-se dentro das expectativas esperadas, visto que haviam indícios de que a qualidade do serviço oferecido pelo Uber era superior ao do táxi, devido à mudança de paradigma ocasionada com a sua entrada no mercado, pois foram apresentados novos conceitos de qualidade aos usuários. Podem também (os resultados) serem utilizados pelos dois serviços avaliados para que possam identificar os pontos fracos e fortes e quais são passíveis de melhora (na percepção do usuário) com o menor esforço possível (por parte do gestor).

A diferença de pontuação entre os dois serviços na avaliação média final foi significativa, visto que o serviço de táxi ficou próximo ao nível "Indiferente" demonstrando baixo índice de satisfação pelos usuários e bastante potencial para melhoras.

Em relação ao serviço Uber, foi identificado um nível muito bom na média dos serviços avaliados, porém, ainda existem critérios em que há a necessidade de investir mais, tal como o serviço adaptado para Pessoas com Necessidades Especiais - PNE.

A vantagem da utilização deste modelo multicritério para avaliar os sistemas de transporte é que ele parte dos pontos de qualidade “esperados/desejáveis" pelos gestores, sendo estabelecidos por eles próprios os critérios a serem avaliados pelos usuários (destinatários finais do serviço), e os usuários avaliam de acordo com a sua percepção, ou seja, "como" o serviço chegou até eles.

A presente avaliação da percepção de qualidade dos serviços permite aos gestores verificarem a efetividade de suas ações, de acordo com suas expectativas, para aferirem a satisfação do usuário final e oportuniza a correção dos pontos críticos para melhor atendê-lo.

Para futuras pesquisas, sugere-se uma nova aplicação do Método MCDA-C frente ao novo cenário, em que a Câmara Legislativa do Distrito Federal regulamentou o serviço Uber, e após o Poder Executivo definir os critérios que afetam a sua utilização, qualidade, quantidade de motoristas e fiscalização dos serviços pelo poder público, a fim de verificar eventual mudança de comportamento ou melhoria do serviço prestado aos usuários do táxi, ou ainda verificar se, com o passar do tempo, o serviço Uber reduzirá seu conceito de qualidade junto aos usuários. 


\section{REFERÊNCIAS BIBLIOGRÁFICAS}

ALEXANDRINO, M. (2009) Direito Administrativo descomplicado/Marcelo Alexandrino, Vicente Paulo - 17. ed., rev. atual. e ampl. - Rio de Janeiro: Forense; São Paulo: MÉTODO,

AMORIM, C. G., GONZÁlEZ, M. O. A, e RAMOS R. E. B. (2004) A relação entre a satisfação e a fidelização dos clientes com a lucratividade das empresas. XXIV Encontro Nacional de Engenharia de Produção. Florianópolis-SC. 03 - 05 nov.

ANJOS, L. A. M., MOURA, H. P. (2016) Um Modelo para Avaliação de Produtos de Software. Disponível em < http://www.cin.ufpe.br/hermano/laps/download/laps-um-modelo-paraavaliacao-de-produtos-de-software.pdf> Acesso em 13/04/2016.

ANTP - ASSOCIAÇÃO NACIONAL DE TRANSPORTES PÚBLICOS (1997) Transporte Humano - cidades com qualidade de vida. Coordenadores: Ailton Brasiliense Pires, Eduardo Alcântara Vasconcellos, Ayrton Camargo e Silva. Apresentação: Rogerio Belda. São Paulo, ANTP, p. 312

ARQUIVO PÚBLICO DO DISTRITO FEDERAL - ArPDF (2016). Consulta realizada em 30/04/2016.

BAER, W. (2009) A economia brasileira. 3. ed. São Paulo: Nobel.

BANA E COSTA, C. A., DE CORTE, J. M. e VANSNICK, J. C. MACBETH. (2003) LSEOR 03.56. The London School of Economics and Political Science, Londres.

BAPTISTA, S. G. (2004) A importância do estudo sobre a imagem organizacional para as unidades de informação e para seus gestores. Biblios, v. 5, n 18-19.

BELUZO, C. E., SANTOS, D. C., CUZNER, D. G., SANTOS, E. C. M., BARBOSA E. S., e BARCELOS, T. S. (2014) Avaliação da usabilidade de software de dispositivo de navegação por gps. Sinergia, São Paulo, v.15, n.2, p 99-104, abr/jun.

BOBBIO, N. (2007) Estado, Governo, Sociedade - Para uma teoria geral da política. Paz e Terra. Rio de Janeiro - RJ.

BRASIL (1988). Constituição Federal da República Federativa do Brasil. Promulgada em 05 de outubro de 1988.

BRASIL (1964) Lei no 4.545, de 10 de dezembro de 1964. Brasília, DF.

BRASIL (1995) Lei no 8.987, de 13 de fevereiro de 1995. Brasília, DF.

BRASIL (2012) Lei no 12.587, de 03 de janeiro de 2012. Brasília, DF.

BRASIL (2012) Lei n 12.865 , de 09 de outubro de 2013. Brasília, DF.

BRASIL (2013) Medida Provisória nº 615, de 17 de maio de 2013. Brasília, DF. 
BROTHERTON, B. (1999) Towards a definitive view of the nature of hospitality and hospitality management. International Journal of Contemporary Hospitality Management, v. 11, n. 4: 165-173.

CAMARA DOS DEPUTADOS (2015). Projeto de Lei nº 3.384/2015. Brasília, DF.

CAMARA LEGISLATIVA (2015) Projeto de Lei nº 282/2015; Projeto de Lei $n^{\circ}$ 777/2015. Brasília, DF.

CAMBRIDGE, Dictionaries Online (2016) Disponível em: 〈http://dictionary.cambridge.org/> Acesso em 30/03/2016.

CARDOSO, L., MATOS, R; (2007) Acessibilidade Urbana e Exclusão Social: novas Relações, velhos Desafios. 2007. Disponível em <http://redpgv.coppe.ufrj.br/index.php/pt-BR/producaoda-rede/artigos-cientificos/2007-1/304-acessibilidade-e-exclusao-simpurb2007/file> Acesso em: 13/04/2016.

CAUCHICK M. P. (2010) Metodologia de Pesquisa em Engenharia de Produção e Gestão de Operações. Elsevier, Rio de Janeiro.

CEFTRU - CENTRO DE FORMAÇÃO DE RECURSOS HUMANOS EM TRANSPORTES. UNIVERSIDADE DE BRASÍLIA. (2006) Relatório da base de fundamentos e critérios para a avaliação, aperfeiçoamento e desenvolvimento de indicadores. Convênio MT/ 2005. Metodologia integrada de suporte ao planejamento, acompanhamento e avaliação dos programas de transportes, do Plano Plurianual 2004/2007, no âmbito do Ministério dos Transportes, como elemento de auxílio à gestão da política de transportes. Brasília, 2006

CERVERO, R. (1997) Paratransit in America: redefining mass transportation. Westport, Connecticut. London. Praeger.

CNT (2002). Confederação Nacional do Transporte. Pesquisa da Seção de Passageiros CNT 2002 Relatório Analítico: Avaliação da Operação dos Corredores de Transporte Urbano por Ônibus no Brasil. CNT, 2002;

COSTA, M. A. (2008) Um índice de mobilidade urbana sustentável. Escola de Engenharia de São Carlos, Universidade de São Paulo.

CROSBY, P. B. (1985) Qualidade é investimento. Rio de Janeiro: José Olympio.

CROSBY, P. B. (1990) Qualidade - falando sério. São Paulo: McGraw-Hill.

CRUZ, F. V., COSTA, H. G., DA HORA, H. R. M., MIRANDA, R. C. (2013) Avaliação na qualidade do transporte urbano semi-público na modalidade táxi segundo a percepção do usuário. IV Encontro Fluminense de Engenharia de Produção - ENFEPro. 22 e 23 ago. 2013.

CYBIS, W.; BETIOL, A.; FAUST, R. (2010). Ergonomia e Usabilidade Conhecimentos, Métodos e Aplicações. São Paulo: Novatec.

DAMATTA, R. (2010). Fé em Deus e pé na tábua ou como e porque o transito enlouquece no Brasil. Rio de Janeiro: Rocco. 
DEPARTAMENTO DE TRÁFEGO E CONCESSÕES. (1966) Edital nº 1-66 - DTC. Distrito Federal. Diário Oficial da União, Brasília, DF, 02 fev. 1966. Seção 1, parte 1.

DEPARTAMENTO DE TRÂNSITO DO DISTRITO FEDERAL - DETRAN. (2016) Frota de Veículos Registrados no Distrito Federal. Disponível em: <http://www.detran.df.gov.br/images/04_abril_2016_frota.pdf>. Acesso em 12/06/2016.

DI PIETRO, M. S. Z. (2006). Direito Administrativo. 19. ed. São Paulo: Atlas.

DIAS, F. A. O. (2007). Serviços de Táxi: Elementos para um Novo Modelo Regulatório. Dissertação de Mestrado, Publicação T.DM-010A/2007, Departamento de Engenharia Civil e Ambiental, Universidade de Brasília, Brasília, 98 p.

DISTRITO FEDERAL (1964) Decreto n 301, de 06 de maio de 1964. Brasília, DF.

DISTRITO FEDERAL (1965) Decreto $\mathrm{n}^{\circ}$ 471, de 27 de dezembro de 1965. Estabelece as condições para a outorga da permissão para a execução do serviço de transporte em automóveis de passageiros a frete, no Distrito Federal. Disponível em Diário Oficial da União, Brasília, DF, 29 dez. 1965. Seção 1, p. 63.

DISTRITO FEDERAL (1967) Decreto $n^{\circ}$ 614, de 18 de maio de 1967; Decreto $n^{\circ}$ 673, de 07 de novembro de 1967. Brasília, DF.

DISTRITO FEDERAL (1968) Decreto n 792, de 29 de agosto de 1968. Brasília, DF.

DISTRITO FEDERAL (1970) Decreto n 1.376, de 30 de junho de 1970. Brasília, DF.

DISTRITO FEDERAL (1972) Decreto nº 2.064, de 28 de setembro de 1972. Brasília, DF.

DISTRITO FEDERAL (1973) Decreto n ${ }^{\circ} 2.301$, de 29 de junho de 1973; Decreto ${ }^{\circ}$ 2.342, de 08 de agosto de 1973. Brasília, DF.

DISTRITO FEDERAL (1974) Decreto nº 2.527, de 17 de janeiro de 1974. Brasília, DF.

DISTRITO FEDERAL (1977) Decreto n 3 3.905, de 13 de outubro de 1977. Brasília, DF.

DISTRITO FEDERAL (1979) Decreto n 4.596, de 13 de março de 1979. Brasília, DF.

DISTRITO FEDERAL (2014) Decreto n 35.748, de 21 de agosto de 2014. Brasília, DF.

DISTRITO FEDERAL (2016) Decreto no 37.189, de 17 de março de 2016. Brasília, DF.

DISTRITO FEDERAL (2014) Lei n 5.323, de 17 de março de 2014. Brasília, DF.

DISTRITO FEDERAL (1961) Portaria nº 70, de 27 de abril de 1961. Brasília, DF.

DF MEMÓRIA TRANSPORTES (2009) Disponível em

<http://dftrans.blogspot.com.br/2009/05/taxi-em-1960.html> Acesso em: 25/10/2015 
DRUCKER, P. (1989) The Practice of Management, Butterworth-Heinemann Ltda.

DRUMOND, E. C., FERREIRA, K. A. M (2002) Normas ISO para usabilidade. Instituto de Ciências Exatas - Departamento de Ciências da Computação - Universidade Federal de Minas Gerais.

ENSSLIN, L.; MONTIBELLER, G; NORONHA, S. (2001). Apoio à Decisão - Metodologia para Estruturação de problemas e Avaliação Multicritério para alternativas. INSULAR: Florianópolis.

FERRAZ, A. C. P.; TORRES, I. G. E. (2001). Transporte Público Urbano. 1 ed.. São Carlos: RIMA, 2001. 367p.

FLEURY, F., WANKE, P., FIGUEIREDO, K. F., CEL (2000) Centro de Estudos em Logística, Logística Empresarial: a perspectiva brasileira, Atlas, São Paulo.

FONSECA, A. P.; RODRIGUES, E. C. C.; DA SILVA, R. B. (2015). Avaliação da Qualidade do Sistema BRT/SUL de Brasília/DF segundo a percepção dos usuários. Anais do XXIX Congresso Nacional de Pesquisa em Transporte, ANPET, Ouro Preto/SP, v. 1. p.1211-1222.

FURTADO, N.; KAWAMOTO, E. (1997) Avaliação de Projetos de Transporte. São Carlos, Escola de Engenharia de São Carlos. Apostila. 1. ed.

GIANESI, I. G. N.; CORRÊA, H. L. (1995) Gestão estratégica de operações de serviço. São Paulo: Encontro do Cladea, 1995. Corrêa e Associados Estratégia de Manufatura e Serviços. Disponível em

http://www.correa.com.br/biblioteca/artigos/A03_Cladea_1995_Gestao_estrategica_de_opera coes.pdf> Acesso em: 13/04/2016.

GOMIDE, A. (2011) Instrumentos de desestímulo ao uso do transporte individual motorizado: lições e recomendações / Alexandre Gomide \& Renato Morato. São Paulo: Instituto de Energia e Meio Ambiente (série temas e debates)

HESKETT, L. \& SCHLESINGER, A. (1994) - Putting the service-profit chain to work. Harvard Business Review. Vol. 72, n.2, p.164-174.

IBGE - INSTITUTO BRASILEIRO DE GEOGRAFIA E ESTATÍSTICA (1980) Censo demográfico. Rio de Janeiro.

IBGE - INSTITUTO BRASILEIRO DE GEOGRAFIA E ESTATÍSTICA (2007) Contagem populacional. Rio de Janeiro.

IBGE - INSTITUTO BRASILEIRO DE GEOGRAFIA E ESTATÍSTICA (2014) Contagem populacional. Rio de Janeiro.

IBGE - INSTITUTO BRASILEIRO DE GEOGRAFIA E ESTATÍSTICA (2015) Estimativa populacional. Rio de Janeiro. 
JACOBS, J. (2011) Morte e vida das grandes cidades/Jane Jacobs; tradução Carlos S. Mendes Rosa; revisão da tradução Maria Estela Heider Cavalheiro; revisão técnica Cheila Aparecida Gomes Bailão. 3. ed, São Paulo: Ed. WMF Martins Fontes. (Coleção Cidades)

JAMMAL, M. C. (2010.) Análise dos requisitos de qualidade do transporte coletivo urbano de São José do Rio Preto - SP usando o método QFD. Cento de Ciências Exatas e de Tecnologia, Universidade Federal de São Carlos. São Carlos - SP.

JORDAN, P.W. (1993). First Workshop on Human-Computer Interaction. Glasgow, UK.

JORDAN, P. W. (1998). An introduction to usability, Taylor \& Francis, London.

KANG, C. H. (1998) Taxi Deregulation: International Comparison, Dissertação de Mestrado em Engenharia de Transporte e Planejamento, Institute for Transport Studies. The University of Leeds. Disponível em <http://www.taxi-library.org/kang0898.htm> Acesso em: 25/10/2015.

KELLER, K e KOTLER P. (2006) Administração de Marketing, 12. ed., São Paulo: Pearson Prentice Hall.

KHISTY, C. J. (1990) Transportation Engineering: An Introduction, Prentice Hall, Englewood Cliffs, NJ, EUA.

KLUTHCOVSKY, A. C. G. C; TAKAYANAGUI, A.M.M. (2007) Qualidade de Vida Aspectos Conceituais. Revista Salus. Guarapuava, PR.

KNEIB, E. C.; (2012) Mobilidade urbana e qualidade de vida: do panorama geral ao caso de Goiânia; Revista UFG; ANOXIII, Nº 12, julho, 2012.

LAKATOS, E. M., MARCONI, M. A. (2001) Metodologia do trabalho científico. 6 ed. São Paulo, SP: Atlas.

LAKATOS, E. M., MARCONI, M. A. (2003) Fundamentos da Metodologia Científica. 5 ed. São Paulo, SP: Atlas.

LUDD, N (org.). (2004b) Carros e Remédios. In: LUDD, N (org.). Apocalipse motorizado: A tirania do automóvel em um planeta poluído. São Paulo: Conrad Editora do Brasil, (Coleção Baderna)

MAIA, A. C. L., (2013) Avaliação da Qualidade do transporte público sob a ótica da Mobilidade Urbana Sustentável - O caso de Fortaleza. Escola de Engenharia de São Carlos, Universidade de São Paulo.

MANHEIM, L. (1979) Fundamentals of Transportation Systems Analysis. MIT Press, Cambridge, MA.

MARAFON, A. D.; ENSSLIN, L.; ENSSLIN, S. R.; ROCHA, S.; MEDAGLIA, T. A. (2013). Modelo multicritério de apoio à decisão construtivista no processo de avaliação de fornecedores. Produção, v. 23, n. 2, p 402-421, 
MARINS, C. S.; (2007) Uma abordagem multicritério para a avaliação e classificação da qualidade do transporte público por ônibus segundo a percepção dos usuários. Universidade Estadual do Norte Fluminense. Campos dos Goytacazes.

MARQUES, B.A.; SILVA, M. C. M. (2008) Qualidade de Software: Uma Análise a partir dos Critérios da Norma ISSO 9126. XXXII Encontro da ANPAD. Rio de Janeiro- RJ. 06 a 102008.

MARTINS, R. A. (2012) Abordagens Quantitativa e Qualitativa. In: MIGUEL, P. A. C. (coord.). Metodologia de Pesquisa em Engenharia de Produção e Gestão de Operações. 2 ed. Rio de Janeiro: Elsevier.

MARTINS, W. T. (2015). Índice de Avaliação da Qualidade do Transporte Público por Ônibus a Partir da Definição de Serviço Adequado. Dissertação de Mestrado em Transportes, Publicação T. DM - 001 A/2015, março, 2015, Departamento de Engenharia Civil e Ambiental, Universidade de Brasília, Brasília, DF, 117 p.

MAXIMIANO, A. C. A. (2008) Teoria geral da administração. 1. ed. 5. reimpr. - São Paulo: Atlas.

MEEBERG, A. G. (1993) Quality of life: a concept analysis. J. Adv Nurs, 18:328.

MEIRELLES, H. L. (2009) Direito Administrativo Brasileiro. 35 ed. São Paulo: Malheiros.

MICHAELIS, Dicionário Online. (2016) Disponível em: < http://michaelis.uol.com.br/> Acesso em 30/03/2016.

MOLLER, C. (2001) O lado humano da qualidade: maximizando a qualidade de produtos e serviços através do desenvolvimento das pessoas. São Paulo: Pioneira Thompson Learning.

MORAES, R. (2001) Neoliberalismo. De onde vem, para onde vai?. São Paulo: Editora Senac. $151 \mathrm{p}$.

NBR ISO/IEC 9126-1. Engenharia de Software - Qualidade de produto. Parte 1: Modelo de qualidade. $\quad$ Jun. 2003. Disponível em: http://luizcamargo.com.br/arquivos/NBR\%20ISO_IEC\%209126-1.pdf> Acesso em 13/04/2016.

NIELSEN, J. (1993). 230 Tips and Tricks for a Better Usability Test. Nielsen Norman Group.

NIELSEN, J. (1995) How to conduct a Heuristic Evaluation. Disponível em: $<$ https://www.nngroup.com/articles/how-to-conduct-a-heuristic-evaluation/> Acesso em $14 / 04 / 2016$.

NIELSEN, J. 10 Usability Heuristics for User Interface Design (1995b). Disponível em: <https://www.nngroup.com/articles/ten-usability-heuristics/>. Acesso em 14/04/2016.

NORIEGA, L.A; WAISMAN, J. (2006) Relevant aspects of automobile users behaviour: a study under the sustainable consumption concept in the transportation sector. Departamento de Engenharia de Transporte. Escola Politécnica da Universidade de São Paulo, Brasil. WIT Transactions on Ecology and the Environment, Vol 93. 
OFFE, C. A. (1983) Democracia partidária competitiva e o "welfare state" keynesiano: Fatores de estabilidade e desorganização.Traduzido por Fanny Wrobel. Dados - Revista de Ciências Sociais, v. 26, nº 1, Pp. 29-51.

OLIVEIRA, G. F., TYBUSCH, F. B. A. (2015) A sociedade de consumo, globalização e tecnologia: O desenvolvimento de aplicativos online como alternativas de conscientização dos cidadãos em busca do meio ambiente sustentável. Direito, globalização e responsabilidade nas relações de consumo. CONPEDI/UFS - Florianópolis: CONPEDI.

ORR, D. (1969). The "Taxicab problem": a proposed solution. Journal of Political Economy 77 (1969), 141-147.

RAFAEL, J. G. O. (2015). Análise Multicritério para Avaliação Comparativa da Usabilidade entre o Sistema de Transporte Público Coletivo de Brasília e Estocolmo. 2015. Trabalho de Conclusão de Curso de Graduação em Administração, Universidade de Brasília.

PALADINI, E. P.; CARVALHO, Marly M. (2005) Gestão da qualidade: teoria e casos. Rio de Janeiro: Elsevier.

PARANHOS, G. C. (2011). Avaliação da Configuração de Redes de Transporte Público Urbano por Meio de Indicadores. Dissertação de Mestrado em Transportes, Publicação T.DM009A/2011, Departamento de Engenharia Civil e Ambiental, Universidade de Brasília, DF, 95p.

PRODANOV, C. C., FREITAS, E. C. (2013) METODOLOGIA DO TRABALHO CIENTÍFICO: Métodos e Técnicas da Pesquisa e do Trabalho Acadêmico. 2. ed. Universidade Feevale. Novo Hamburgo-RS.

QUIRINO, M. G. (2002). Incorporação das Relações de Subordinação na Matriz de Ordenação - Roberts em MCDA quando os Axiomas de Assimetria e Transitividade Negativa são Violados. Tese de Doutorado em Engenharia de Produção, Universidade Federal de Santa Catarina.

RAMOS, M. W. (2013) Qualidades medida e percebida no sistema de transporte coletivo por ônibus: estudo de caso de Belo Horizonte.

RECK, G. (2016) Apostila de Transporte Público. Universidade Federal do Paraná - UFPR. Departamento de Transportes. Disponível em: <http://www.dtt.ufpr.br/Transporte\%20Publico/Arquivos/TT057_Apostila.pdf> Acesso em: $13 / 04 / 2016$.

RIBEIRO, A. C. S., FREITAS, A. L. P. (2012) Emprego da análise de regressão múltipla na identificação dos fatores relevantes na qualidade do transporte rodoviário intermunicipal de passageiros. XIX Simpósio de Engenharia de Produção - SIMPEP. 05 a 07 nov. 2012.

RODRIGUES, M.A. (2008). Análise do transporte coletivo urbano com base em indicadores de qualidade. Dissertação de Mestrado, Faculdade de Engenharia Civil, Universidade Federal de Urberlândia, 2008. 
RODRIGUES, E. C. C. (2014). Metodologia para investigação da percepção das inovações na usabilidade do sistema metroviário - uma abordagem antropotecnológica. Tese de doutorado em Transportes. Publicação T. D. - 006 / 2014. Departamento de Engenharia Civil e Ambiental. Universidade de Brasília, DF, 262 p.

RODRIGUES, E. C. C.; RAFAEL, J. G. O.; DA SILVA, R. B. (2016). Análise multicritério para avaliação comparativa entre os sistemas de transporte público coletivo de Brasília e de Estocolmo: a percepção do usuário - DOI: 10.5102/un.gti.v6i1.3869. Universitas: Gestão e TI, v. 6, p. $836-850$.

SANTOS, G. E. O. (2016) Cálculo amostral: calculadora on-line. Disponível em: <http://www.calculoamostral.vai.la>. Acesso em: $1^{\circ}$ de maio de 2016.

SANTOS, R. G. (2014). Propostas para melhoria contínua da qualidade do transporte público coletivo do Distrito Federal utilizando a escala Servqual, Publicação T.DM - 002 A/2014, Departamento de Engenharia Civil e Ambiental, Faculdade de Tecnologia, Universidade de Brasília, Brasília, DF, 140p.

SILVEIRA JR. A., RODRIGUES, E. C. C., RODRIGUES, M. M. V. O. C, MARTINS, N. S., SILVA, R. B. S. (2015) Critérios de usabilidade para avaliação das condições de uso da estação central do METRÔ-DF. $20^{\circ}$ Congresso Brasileiro de Transporte e Trânsito. ANTP. Santos-SP. 23 a 25 jun. 2015.

SILVA, D. P. (2005) Avaliação da qualidade em serviço de entrega em domicílio no setor farmacêutico: uma aplicação do método SERVQUAL, usando a análise fatorial. Dissertação (Mestrado em Ciências) - Programa de Pós-graduação em Métodos Numéricos em Engenharia, Universidade Federal do Paraná, Curitiba, 2005.

SILVA, E. L., MENEZES, E. M. (2001) Metodologia da pesquisa e elaboração de dissertação. 3 ed. Florianópolis: Laboratório de Ensino a Distância da UFSC.

SIMIONATTO, R. D. T. (2006) Identificação de dimensões do serviço ao cliente relevantes à logística no setor de serviços. Campinas, SP.

TELFER, E. (1996) Food for Thought: Philosophy and Food. London. Routledge.

TEZZA, R.; ZAMCOPÉ, F. C. e ENSSLIN, L. (2010). A metodologia multicritério de apoio à decisão construtivista para a identificação e avaliação de habilidades para o setor de estamparia têxtil. GEPROS. Gestão da Produção, Operações e Sistemas - Ano 5, nº 1, Jan- Mar/2010, p. 125-142.

TIDD, J. BESSANT, J. (2008) Managing Innovation: Integrating Technological, Market and Organizational Change, 4. ed. Chichester: John Wiley.

UBER BRASIL (2016) Disponível em < https://newsroom.uber.com/tag/uber-brasil/> Acesso em: 14/04/2016. 


\section{APÊNDICES}

\section{APÊNDICE A - FORMULÁRIO DE DEFINIÇÃO DOS PVF’s e SUBPFV’s E TAXAS DE SUBSTITUIÇÃO JUNTO AOS ESPECIALISTAS (BRAINSTORMING)}

\begin{tabular}{|c|c|c|}
\hline \multicolumn{3}{|c|}{ BRAINSTORMING - DEFINIÇÃO NA PERSPECTIVA DE AVALIAÇÃO PELO USUÁRIO } \\
\hline PVF & SubPVF & SUBPVF \\
\hline (Critério) & (Subcritério1) & (Subcritério2) \\
\hline \multirow{13}{*}{$\begin{array}{l}\text { OPERAÇÃO } \\
(25 \%)\end{array}$} & \multirow{5}{*}{ 1. Exigência profissional (40\%) } & 1.1. Dirigibilidade / Condução do veículo (30\%) \\
\hline & & 1.2. Gentileza e Empatia no trato verbal $(20 \%)$ \\
\hline & & 1.3. Prestatividade para ações físicas $(20 \%)$ \\
\hline & & 1.4. Higiene pessoal (20\%) \\
\hline & & 1.5. Acesso à segunda língua $(10 \%)$ \\
\hline & \multirow{3}{*}{ 2. Conhecimento do trajeto $(40 \%)$} & 2.1. Sugestão de trajetos possíveis (30\%) \\
\hline & & $\begin{array}{l}\text { 2.2. Proatividade para solucionar problemas de tráfego - } \\
\text { rotas alternativas }(20 \%)\end{array}$ \\
\hline & & 2.3. Pontualidade para chegar ao destino $(50 \%)$ \\
\hline & \multirow{5}{*}{ 3. Conforto do Veículo (20\%) } & 3.1. Espaço interno adequado. (20\%) \\
\hline & & 3.2. Ambiente agradável. (30\%) \\
\hline & & 3.3. Limpeza e conservação. (30\%) \\
\hline & & 3.4. Serviço de bordo adicionais. (10\%) \\
\hline & & 3.5. Espaço do porta-malas (10\%) \\
\hline \multirow{6}{*}{$\begin{array}{l}\text { VALORES } \\
(35 \%)\end{array}$} & \multirow{4}{*}{$\begin{array}{l}\text { 4. Custo x benefício do serviço } \\
(80 \%)\end{array}$} & 4.1. Preço do serviço. (50\%) \\
\hline & & 4.2. Facilidade (formas) de pagamento (20\%) \\
\hline & & 4.3. Controle do valor a ser pago na corrida. $(15 \%)$ \\
\hline & & 4.4. Transparência da forma de cálculo da tarifa. $(15 \%)$ \\
\hline & \multirow{2}{*}{$\begin{array}{l}\text { 5. Intangíveis e valor da marca } \\
(20 \%)\end{array}$} & 5.1. Imagem da marca - táxi ou uber. (30\%) \\
\hline & & 5.2. Percepção de valor do serviço. $(70 \%)$ \\
\hline \multirow{6}{*}{$\begin{array}{l}\text { SUPORTE } \\
(20 \%)\end{array}$} & \multirow{3}{*}{$\begin{array}{l}\text { 6. Acessibilidade (Oferta de } \\
\text { serviço) }(40 \%)\end{array}$} & 6.1 Facilidade de gerar o pedido do serviço $(40 \%)$ \\
\hline & & 6.2 Abrangência de atendimento - Área (50\%) \\
\hline & & 6.3 Adaptação à Necessidades Especiais (10\%) \\
\hline & \multirow{3}{*}{ 7. Tempo $(60 \%)$} & 7.1 Tempo de chegada após pedido (40\%) \\
\hline & & 7.2 Monitoramento da chegada (20\%) \\
\hline & & 7.3 Horário de funcionamento $(40 \%)$ \\
\hline \multirow{6}{*}{$\begin{array}{c}\text { SEGURANÇA } \\
(20 \%)\end{array}$} & \multirow{4}{*}{$\begin{array}{l}\text { 8. Segurança e Confiabilidade } \\
(80 \%)\end{array}$} & 8.1 Sensação de segurança - identificação do serviço (30\%) \\
\hline & & 8.2 Itens de segurança do veículo (15\%) \\
\hline & & 8.3 Privacidade $(15 \%)$ \\
\hline & & 8.4 Confiabilidade - disponibilidade de serviço $(40 \%)$ \\
\hline & \multirow{2}{*}{ 9. Sistema de apoio (20\%) } & 9.1. Serviço "pós-venda" - atendimento. (40\%) \\
\hline & & 9.2. Atendimento para reclamações. $(60 \%)$ \\
\hline
\end{tabular}


APÊNDICE B - FORMULÁRO DE DEFINIÇÃO DE NÍVEL DE ESFORÇO BRAINSTORMING - DEFINIÇÃO DE NÍVEL DE ESFORÇO

\begin{tabular}{|c|c|c|c|c|c|c|c|c|c|}
\hline \multirow[b]{2}{*}{ ITENS } & \multirow{2}{*}{$\begin{array}{l}\text { Critérios de USABILIDADE } \\
\text { Pontuações/Níveis de Esforço }\end{array}$} & \multicolumn{5}{|c|}{ Nível de } & \multirow{2}{*}{$\begin{array}{l}\text { Maior } \\
\text { esforço } \\
\text { do Item }\end{array}$} & \multirow{2}{*}{$\begin{array}{l}\text { Maior } \\
\text { esforc } \\
\text { o }\end{array}$} & \multirow{2}{*}{$\begin{array}{l}\text { Maior } \\
\text { esforç } \\
\text { o }\end{array}$} \\
\hline & & $\begin{array}{l}N \\
1\end{array}$ & $\begin{array}{l}N \\
2\end{array}$ & $\begin{array}{l}N \\
3\end{array}$ & $\begin{array}{l}N \\
4\end{array}$ & $\begin{array}{l}N \\
5\end{array}$ & & & \\
\hline \multirow{5}{*}{ 1. Exigência profissional (40\%) } & 1.1. Dirigibilidade / Condução do veículo (30\%) & & & & & & 3 & \multirow{5}{*}{2} & 19 \\
\hline & 1.2. Gentileza e Empatia no trato verbal (20\%) & & & & & & 1 & & 2 \\
\hline & 1.3. Prestatividade para ações físicas (20\%) & & & & & & 5 & & 30 \\
\hline & 1.4. Higiene pessoal $(20 \%)$ & & & & & & 4 & & 26 \\
\hline & 1.5. Acesso à segunda língua $(10 \%)$ & & & & & & 2 & & 11 \\
\hline \multirow{3}{*}{ 2. Conhecimento do trajeto $(40 \%)$} & 2.1. Sugestão de trajetos possíveis $(30 \%)$ & & & & & & 3 & \multirow{3}{*}{5} & 22 \\
\hline & $\begin{array}{l}\text { 2.2. Proatividade para solucionar problemas de tráfego - rotas } \\
\text { alternativas }(20 \%)\end{array}$ & & & & & & 1 & & 5 \\
\hline & 2.3. Pontualidade para chegar ao destino $(50 \%)$ & & & & & & 2 & & 14 \\
\hline \multirow{5}{*}{ 3. Conforto do Veículo (20\%) } & 3.1. Espaço interno adequado. (20\%) & & & & & & 1 & \multirow{5}{*}{7} & 7 \\
\hline & 3.2. Ambiente agradável. (30\%) & & & & & & 3 & & 24 \\
\hline & 3.3. Limpeza e conservação. (30\%) & & & & & & 4 & & 29 \\
\hline & 3.4. Serviço de bordo adicionais. (10\%) & & & & & & 5 & & 31 \\
\hline & 3.5. Espaço do porta-malas $(10 \%)$ & & & & & & 2 & & 16 \\
\hline \multirow{4}{*}{$\begin{array}{l}\text { 4. Custo x benefício do serviço } \\
(80 \%)\end{array}$} & 4.1. Preço do serviço. $(50 \%)$ & & & & & & 1 & \multirow{4}{*}{4} & 4 \\
\hline & 4.2. Facilidade (formas) de pagamento $(20 \%)$ & & & & & & 3 & & 21 \\
\hline & 4.3. Controle do valor a ser pago na corrida. (15\%) & & & & & & 4 & & 28 \\
\hline & 4.4. Transparência da forma de cálculo da tarifa. (15\%) & & & & & & 2 & & 13 \\
\hline \multirow{2}{*}{$\begin{array}{l}\text { 5. Intangíveis e valor da marca } \\
(20 \%)\end{array}$} & 5.1. Imagem da marca - táxi ou uber. (30\%) & & & & & & 1 & \multirow{2}{*}{1} & 1 \\
\hline & 5.2. Percepção de valor do serviço. $(70 \%)$ & & & & & & 2 & & 10 \\
\hline \multirow{3}{*}{$\begin{array}{l}\text { 6. Acessibilidade (Oferta de } \\
\text { serviço) }(40 \%)\end{array}$} & 6.1 Facilidade de gerar o pedido do serviço (40\%) & & & & & & 3 & \multirow{3}{*}{6} & 23 \\
\hline & 6.2 Abrangência de atendimento - Área (50\%) & & & & & & 1 & & 6 \\
\hline & 6.3 Adaptação à Necessidades Especiais (10\%) & & & & & & 2 & & 15 \\
\hline \multirow{3}{*}{ 7. Tempo $(60 \%)$} & 7.1 Tempo de chegada após pedido (40\%) & & & & & & 1 & \multirow{3}{*}{8} & 8 \\
\hline & 7.2 Monitoramento da chegada $(20 \%)$ & & & & & & 3 & & 25 \\
\hline & 7.3 Horário de funcionamento $(40 \%)$ & & & & & & 2 & & 17 \\
\hline \multirow{4}{*}{$\begin{array}{l}\text { 8. Segurança e Confiabilidade } \\
(80 \%)\end{array}$} & 8.1 Sensação de segurança - identificação do serviço (30\%) & & & & & & 2 & \multirow{4}{*}{3} & 12 \\
\hline & 8.2 Itens de segurança do veículo $(15 \%)$ & & & & & & 4 & & 27 \\
\hline & 8.3 Privacidade $(15 \%)$ & & & & & & 3 & & 20 \\
\hline & 8.4 Confiabilidade - disponibilidade de serviço (40\%) & & & & & & 1 & & 3 \\
\hline \multirow{2}{*}{ 9. Sistema de apoio (20\%) } & 9.1. Serviço "pós-venda" - qualidade do atendimento. (40\%) & & & & & & 2 & \multirow{2}{*}{9} & 18 \\
\hline & 9.2. Atendimento para reclamações. $(60 \%)$ & & & & & & 1 & & 9 \\
\hline
\end{tabular}




\section{APÊNDICE - C - QUESTIONÁRIO IMPRESSO COM USUÁRIOS}

\section{PERCEPÇÃO DE QUALIDADE NO SERVIÇO DE TRANSPORTE INDIVIDUAL DO DF}

Prezado(a) colaborador(a), você está sendo convidado(a) para participar, como voluntário(a), de pesquisa sobre a percepção de qualidade do sistema de transporte individual no DF, vinculada ao Programa de Pós-graduação em Transportes - PPGT da

Universidade de Brasília - UnB. Todas as informações coletadas nesta pesquisa são sigilosas e sua identidade será preservada.

* É importante que você, colaborador, tenha utilizado o serviço por pelo menos 03 (três) vezes.

Obrigado pela sua participação!

\begin{tabular}{|c|c|c|c|c|}
\hline Sexo: & Faixa etária: & Renda média familiar: & Grau de instrução: & Quantas vezes utilizou o Serviço no DF? \\
\hline $\begin{array}{l}\text { ( ) masculino } \\
\text { ( ) feminino }\end{array}$ & $\begin{array}{l}\text { ( ) menos de } 18 \text { anos } \\
\text { ( ) } 18 \text { a } 25 \text { anos } \\
\text { ( ) } 26 \text { a } 35 \text { anos } \\
\text { ( ) } 36 \text { a } 45 \text { anos } \\
\text { ( ) } 46 \text { a } 55 \text { anos } \\
\text { ( ) mais de } 55 \text { anos }\end{array}$ & $\begin{array}{l}\text { ( ) menos de } 2 \text { salários mínimos } \\
\text { ( ) mais de } 2 \text { e menos de } 4 \text { salários mínimos } \\
\text { ( ) mais de } 4 \text { e menos de } 10 \text { salários mínimos } \\
\text { ( ) mais de } 10 \text { e menos de } 20 \text { salários mínimos } \\
\text { ( ) mais de } 20 \text { salários mínimos }\end{array}$ & $\begin{array}{l}\text { ( ) Fundamental } \\
\text { ( ) Médio } \\
\text { ( ) Superior } \\
\text { ( ) Pós-Graduação } \\
\text { ( ) Mestrado } \\
\text { ( ) Doutorado }\end{array}$ & $\begin{array}{l}\text { ( ) nunca utilizei } \\
\text { ( ) utilizei } 1 \text { ou } 2 \text { vezes } \\
\text { ( ) utilizei } 3 \text { ou } 4 \text { vezes } \\
\text { ( ) utilizei } 5 \text { vezes ou mais }\end{array}$ \\
\hline
\end{tabular}

Possui facilidade/domínio em comprar bens ou contratar serviços pela Web? ( ) Sim ( ) Não $\quad$ Já utilizou o serviço de rádio táxi no DF? ( ) Sim ( ) Não

\begin{tabular}{|l|l|l|}
\hline SERVIÇO AVALIADO: & ( ) TÁXI & ( ) UBER \\
\hline
\end{tabular}

- Preencha, de acordo com os critérios abaixo, sua perspectiva acerca do serviço de transporte individual no DF:

\begin{tabular}{|l|l|l|l|l|}
\hline (N1) RUIM Ou INEXISTE O SERVIÇO & (N2) INDIFERENTE & (N3) BOM & (N4) MUITO BOM & (N5) EXCELENTE \\
\hline
\end{tabular}

\begin{tabular}{|c|c|c|c|c|c|c|}
\hline \multirow[b]{2}{*}{ ITEM } & \multirow[b]{2}{*}{ Qual a sua percepção sobre a qualidade do Serviço com base no item: } & \multicolumn{5}{|c|}{ PONTUAÇÃO } \\
\hline & & $\begin{array}{l}\text { N1 } \\
\text { Rui }\end{array}$ & $\begin{array}{l}\text { N2 } \\
\text { Ind }\end{array}$ & $\begin{array}{l}\text { N3 } \\
\text { Bom }\end{array}$ & N4 & $\begin{array}{l}\text { N5 } \\
\text { Exc }\end{array}$ \\
\hline \multirow{5}{*}{$\begin{array}{l}\text { 1. Exigência } \\
\text { profissional }\end{array}$} & 1.1. Dirigibilidade / Condução do veículo & & & & & \\
\hline & 1.2. Gentileza e empatia no trato verbal (Ex.: cumprimentar, dar bom dia...) & & & & & \\
\hline & 1.3. Pres tatividade para ações fís icas (Ex.: abrir a porta, carregar mala, ajudar idoso entrar...) & & & & & \\
\hline & 1.4 Higiene pes soal (Ex.: não apres entar mau cheiro ou mau hálito, com barba feita...) & & & & & \\
\hline & 1.5 Acesso a uma segunda língua (Ex.: capacidade de se comunicar em outro idioma) & & & & & \\
\hline \multirow{3}{*}{$\begin{array}{l}2 . \\
\text { Conhecimento } \\
\text { do trajeto }\end{array}$} & 2.1. Sugestão de trajetos possíveis & & & & & \\
\hline & 2.2. Capacidade para solucionar problemas de tráfego (rotas alternativas, des vios...) & & & & & \\
\hline & 2.3. Pontualidade para chegar ao destino & & & & & \\
\hline \multirow{5}{*}{$\begin{array}{l}\text { 3. Conforto do } \\
\text { Veículo }\end{array}$} & 3.1. Es paço interno adequado & & & & & \\
\hline & 3.2. Ambiente agradável. & & & & & \\
\hline & 3.3. Limpeza e cons ervação do veículo & & & & & \\
\hline & 3.4. Serviço de bordo adicionais & & & & & \\
\hline & 3.5 Es paço do porta-malas & & & & & \\
\hline \multirow{4}{*}{$\begin{array}{l}\text { 4. Custo } \mathrm{x} \\
\text { benefício do } \\
\text { serviço }\end{array}$} & 4.1. Preço do serviço & & & & & \\
\hline & 4.2. Facilidade (formas) de pagamento & & & & & \\
\hline & 4.3. Controle do valor a ser pago na corrida (ver o preço inicial e sua evolução na viagem) & & & & & \\
\hline & 4.4. Transparência da fórmula de cálculo da tarifa & & & & & \\
\hline \multirow{2}{*}{$\begin{array}{l}\text { 5. Intangíveis e } \\
\text { valor da marca }\end{array}$} & 5.1. Imagem da marca. (Ex.: qual o valor da imagem da marca TÁXI ou UBER para você?) & & & & & \\
\hline & 5.2. Percepção de valor do s erviço (Ex.: qual o valor atribuido ao s erviço de TÁXI ou UBER?) & & & & & \\
\hline \multirow{3}{*}{$\begin{array}{l}6 . \\
\text { Acessibilidade }\end{array}$} & 6.1 Facilidade de gerar o pedido do serviço & & & & & \\
\hline & 6.2 Abrangência de atendimento - área atendida pelo s erviço & & & & & \\
\hline & $\begin{array}{l}\text { 6.3 Adaptação à Pessoas com Necessidades Especiais - PNE (Ex.: avalie se há disponibilidade } \\
\text { de serviços como carros do tipo Doblô para acomodar PNE? Acha que a quantidade é } \\
\text { suficiente?) }\end{array}$ & & & & & \\
\hline \multirow{3}{*}{ 7. Tempo } & 7.1 Tempo de chegada após o pedido & & & & & \\
\hline & 7.2 Monitoramento da chegada após o pedido & & & & & \\
\hline & 7.3 Horário de funcionamento do serviço & & & & & \\
\hline \multirow{4}{*}{$\begin{array}{l}\text { 8. Segurança e } \\
\text { Confiabilidade }\end{array}$} & 8.1 Sens ação de segurança ao adentrar no veículo - identificação do serviço & & & & & \\
\hline & 8.2 Itens de segurança do veiculo (Ex.: cinto de segurança, airbag, seguro automotivo...) & & & & & \\
\hline & $\begin{array}{l}\text { 8.3 Privacidade em relação ao prestador de serviço (Ex.: respeito a gênero; indagação sobre } \\
\text { informações pes soais de estado civil, e-mail, número do telefone...; diálogo invasivo) }\end{array}$ & & & & & \\
\hline & 8.4 Confiabilidade - dis ponibilidade de serviço quando neces sário & & & & & \\
\hline \multirow{2}{*}{$\begin{array}{l}\text { 9. Sis tema de } \\
\text { apoio }\end{array}$} & $\begin{array}{l}\text { 9.1. Sistema de atendimento ao usuário - dúvidas (Ex.: existe sistema disponivel para tirar } \\
\text { dúvidas? É eficiente? De fácil utilização?) }\end{array}$ & & & & & \\
\hline & $\begin{array}{l}\text { 9.2. Atendimento "pós-venda" e reclamações. (Ex.: existe sistema de avaliação do } \\
\text { serviço/reclamação disponível? Atinge o objetivo? É de fácil utilização?) }\end{array}$ & & & & & \\
\hline
\end{tabular}




\section{Percepção da qualidade da prestação do serviço UBER no Distrito Federal}

Prezado(a) colaborador(a), você está sendo convidado(a) para participar, como voluntário(a), de pesquisa sobre a PERCEPÇÃO de qualidade do serviço UBER no Distrito Federal, vinculada ao Programa de Pós-graduação em Transportes - PPGT da Universidade de Brasília - UnB.

* Caso existam serviços não utilizados por você, favor avaliar a sua PERCEPÇÃO acerca daquele serviço, ou seja, aquilo que você sente/é perceptivel acerca da qualidade do serviço.

Este questionário serve para fins MERAMENTE ACADÊMICOS.

Sua contribuição se dará através da resposta a este questionário que deve levar entre 5 e 8 minutos de resposta.

Todas as informações coletadas nesta pesquisa são sigilosas e sua identidade será preservada. Sempre que quiser você poderá pedir mais informações sobre a pesquisa, entrando em contato com o pesquisador através do e-mail:

fernando.meister@hotmail.com

*É importante que você, colaborador, tenha utilizado o serviço por pelo menos 04 (quatro) vezes.

Obrigado pela sua participação!

Universidade de Brasília -UnB
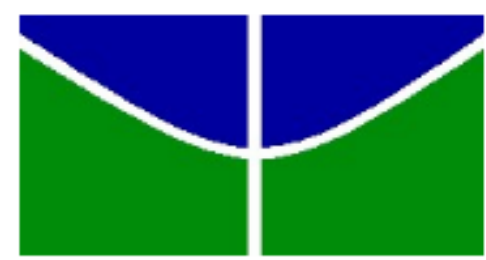

Sexo*

Masculino

Feminino

Faixa Etária *

Menos de 18 anos

18 a 25 anos

26 a 35 anos

36 a 45 anos

46 a 55 anos

mais de 55 anos 


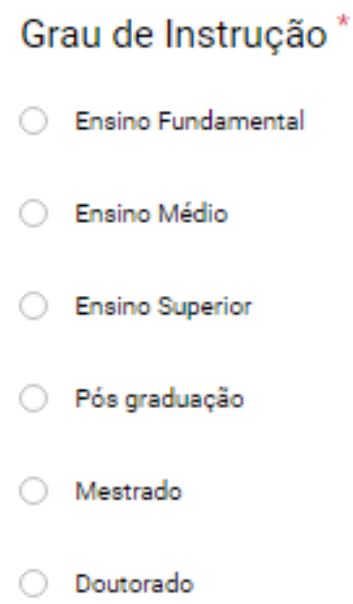

Quantas vezes já utilizou o serviço do UBER no DISTRITO FEDERAL?*

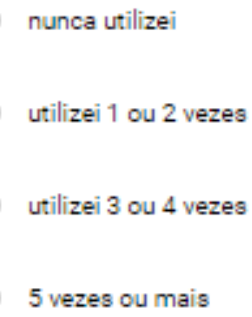

Possui facilidade/domínio em comprar bens ou contratar serviços pela Web? *
Sim
Não

Já utilizou o serviço de rádio táxi no DISTRITO FEDERAL? *
$\operatorname{Sim}$
Não

\section{EXIGÊNCIA PROFISSIONAL DO MOTORISTA DO UBER}

Para cada um dos quesitos de qualidade marque aquele conceito que demonstre o grau de satisfação de acordo com suas experiências na utilização do serviço. 
Dirigibilidade / Condução do veículo *

Excelente
Muito bom
Bom
Indiferente
Ruim ou Inexiste o serviço

Gentileza e empatia no trato verbal (Ex.: cumprimentar, dar bom dia...) *

Excelente
Muito bom
Bom
Indiferente
Ruim ou Inexiste o serviço

Prestatividade para ações físicas (abrir a porta, carregar mala, ajudar idoso a entrar no veículo...)

Excelente
Muito bom
Bom
Indiferente
Ruim ou Inexiste o serviço

Higiene Pessoal (Ex.: não apresentar mau cheiro, mau hálito, com barba feita...)

Excelente

Muito bom

Bom

Indiferente

Ruim ou Inexiste o serviço 
Acesso a uma segunda língua (capacidade de se comunicar em outro idioma) * Se a comunicação em outra língua for irrelevante para você na escolha do transporte no DF, marque "indiferente". Caso entenda que o serviço não disponibiliza essa opção, marque "ruim ou inexiste o serviço".

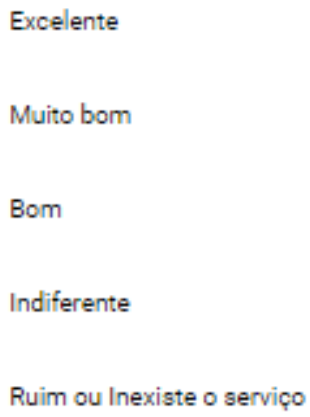

Seção 3 de 10

\section{CONHECIMENTO DO TRAJETO}

Descrį̣ão (opcional)

Sugestão de trajetos possíveis pelo motorista do Uber *

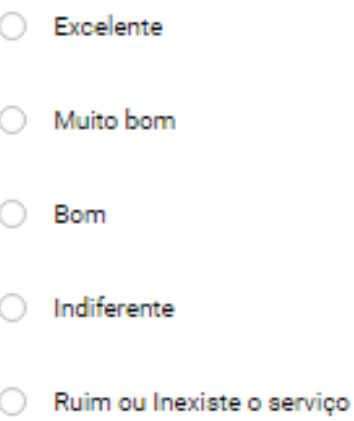

Capacidade para solucionar problemas de tráfego (rotas alternativas, desvios...)

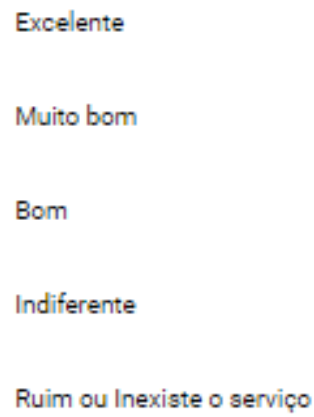


Pontualidade para chegar ao destino *
Excelente
Muito bom
Bom
Indiferente
Ruim ou Inexiste o serviço

\title{
Seção 4 de 10
}

\section{Conforto do Veículo}

Descrição (opcional)

\author{
Espaço interno adequado * \\ Excelente \\ Muito bom \\ Bom \\ Indiferente \\ Ruim ou Inexiste o serviço
}

Ambiente agradável *

Excelente

Muito bom

(1) Bom

Indiferente

Ruim ou Inexiste o serviço 
Limpeza e conservação do veículo *
Excelente
Muito bom
Bom
Indiferente
Ruim ou Inexiste o serviço

Serviço de bordo adicionais *
Excelente
Muito bom
Bom
Indiferente
Ruim ou Inexiste o serviço

\section{Espaço do porta-malas *}

Excelente

Muito bom

Bom

Indiferente

Ruim ou Inexiste o serviço

\section{Seção 5 de 10}

\section{Custo $\mathrm{x}$ benefício do serviço}




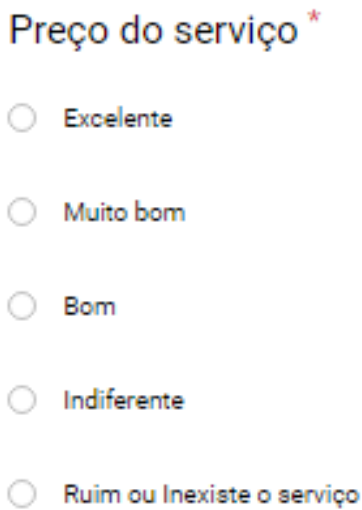

Facilidade de pagamento (Os meios de pagamento disponíveis te atenderam de forma satisfatória?)

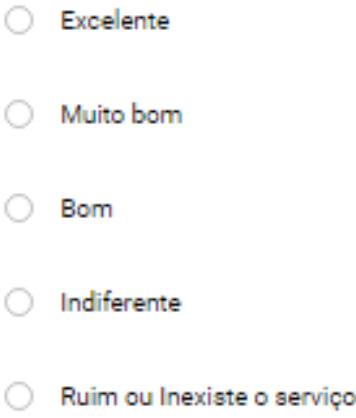

Controle do valor a ser pago na corrida (Ex.: ver o preço inicial e sua evolução * na viagem...)

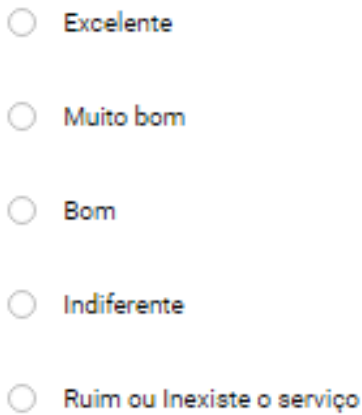

Transparência da forma de cálculo da tarifa *

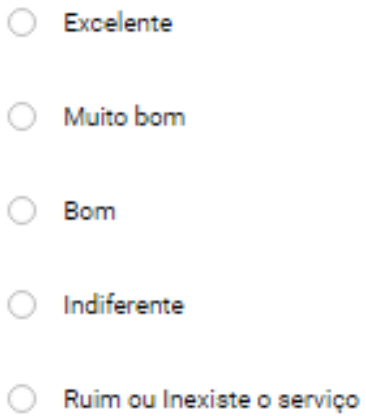




\section{Intangíveis e valor da marca}

Descrị̧ão (opcional)

Imagem da marca - Qual é o valor da marca UBER pra você? (O quê vem à sua * cabeça quando ouve falar na palavra UBER?)

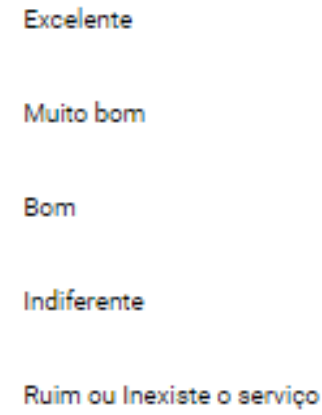

Percepção de valor do serviço (Qual o valor atribuído ao serviço UBER? O quê vem à sua cabeça quando pensa no serviço UBER em geral?)

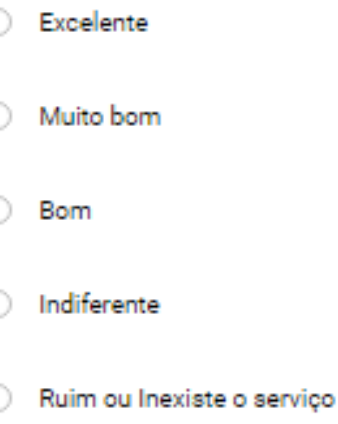


Facilidade de gerar o pedido do serviço *

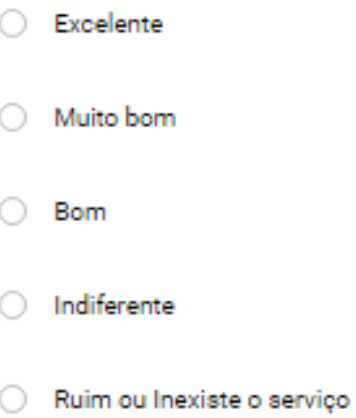

Abrangência de atendimento - Área atendida pelo serviço *

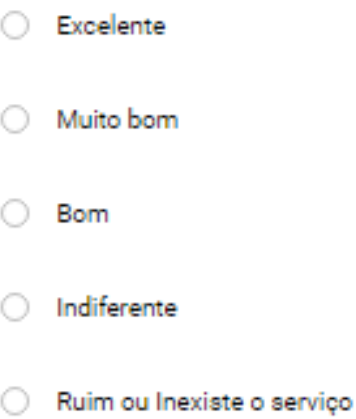

Adaptação à Pessoas com Necessidades Especiais - PNE (Avalie se há disponibilidade de serviços como carros do tipo Doblô para acomodar PNE? Acha que a quantidade é suficiente? Caso entenda que não exista ou a quantidade disponível é insuficiente, avalie "ruim ou inexistente o serviço". Se a existência desse tipo de serviço for indiferente na escolha do transporte, marque "indiferente".)

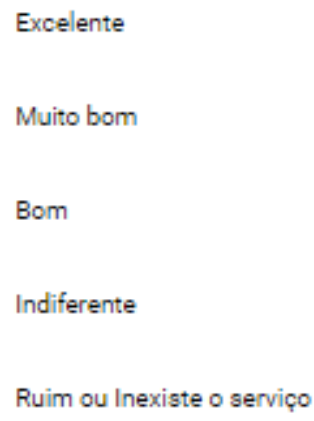

\section{Tempo}


Tempo de chegada após o pedido *

Excelente
Muito bom
Bom
Indiferente
Ruim ou Inexiste o serviço

Monitoramento da chegada após o pedido *

Excelente

Muito bom

Bom

Indiferente

Ruim ou Inexiste o serviço

Horário de funcionamento do serviço *

Excelente

Muito bom

Bom

Indiferente

Ruim ou Inexiste o serviço

\section{Seção 9 de 10}

\section{Segurança e Confiabilidade}

Descrição (opcional) 
Sensação de segurança ao adentrar no veículo - identificação do serviço *

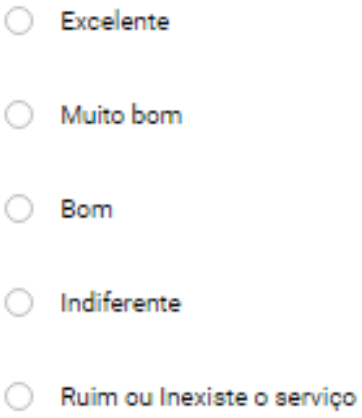

Itens de segurança do veículo (Ex.: cinto de segurança, airbag, seguro automotivo)

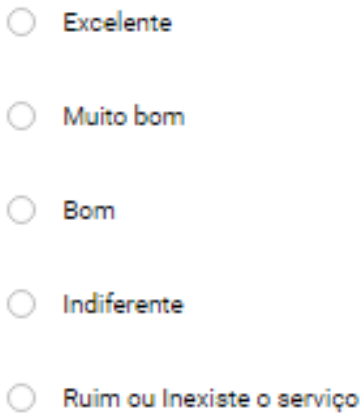

Privacidade em relação ao prestador de serviço (Ex.: respeito a gênero; indagação sobre informações pessoais, de estado civil, e-mail, número de telefone; diálogo invasivo...)

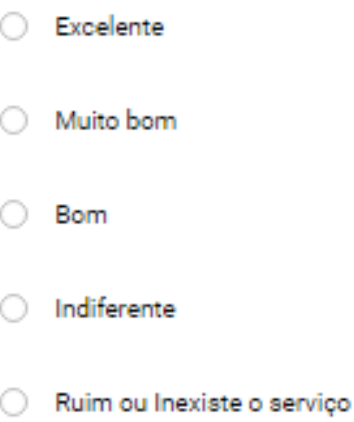


Confiabilidade - disponibilidade de serviço quando necessário *

Excelente

Muito bom

Bom

Indiferente

Ruim ou Inexiste o serviço

\section{Seção 10 de 10}

\section{Sistema de Apoio}

Descrição (opcional)

Serviço de atendimento ao usuários - dúvidas (Ex.: existe sistema disponível para tirar dúvidas? É eficiente? De fácil utilização?)
Excelente
Muito bom
Bom
Indiferente
Ruim ou Inexiste o serviço

Atendimento "pós venda" e reclamações (Ex.: existe sistema de avaliação do serviço/reclamação disponível? Atinge o objetivo? É de fácil utilização?)
Excelente
Muito bom
Bom
Indiferente
Ruim ou Inexiste o serviço 


\section{Percepção da qualidade da prestação do serviço de Táxi do Distrito Federal}

INFORMAÇÕES SOBRE A PESQUISA

Prezado(a) colaborador(a), você está sendo convidado(a) para participar, como voluntário(a), de pesquisa sobre a PERCEPĊ̃̃O da qualidade do Sistema de Transporte Individual TÁXI do Distrito Federal.

* Caso existam serviços não utilizados por você, favor avaliar a sua PERCEPC̣ÃO acerca daquele serviço, ou seja, aquilo que você sente/é perceptivel acerca da qualidade do serviço.

Este questionário serve para fins MERAMENTE ACADÊMICOS.

Sua contribuição se dará através da resposta a este questionário que deve levar entre 5 e 8 minutos de resposta.

Todas as informações coletadas nesta pesquisa são sigilosas e sua identidade será preservada. Sempre que quiser você poderá pedir mais informações sobre a pesquisa, entrando em contato com o pesquisador através do e-mail: fecnande.meister@hotmail.sem.

* É importante que você, colaborador, tenha utilizado o serviço por pelo menos 04 (quatro) vezes.

Obrigado pela participação!

Universidade de Brasília -UnB
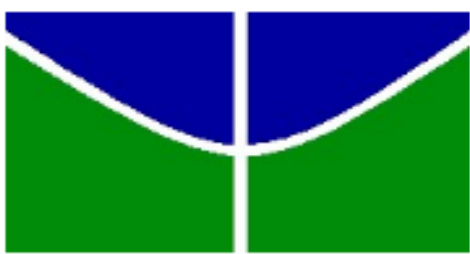

Sexo*

Masculino

Feminino

Faixa Etária *

Menos de 18 anos

18 a 25 anos

26 a 35 anos

36 a 45 anos

46 a 55 anos

mais de 55 anos 


\author{
Grau de Instrução * \\ Ensino Fundamental \\ - Ensino Médio \\ Ensino Superior \\ Pós graduação \\ Mestrado \\ Doutorado
}

Quantas vezes já utilizou o serviço do UBER no DISTRITO FEDERAL?*
nunca utilizei
utilizei 1 ou 2 vezes
utilizei 3 ou 4 vezes
5 vezes ou mais

Possui facilidade/domínio em comprar bens ou contratar serviços pela Web?
Sim
Não

Já utilizou o serviço de rádio táxi no DISTRITO FEDERAL? *
$\operatorname{Sim}$
Não

\title{
Seção 2 de 10
}

\section{EXIGÊNCIA PROFISSIONAL DO TAXISTA}

Para cada um dos quesitos de qualidade marque aquele conceito que demonstre o grau de satisfação de acordo com suas experiências na utilização do serviço. 
Dirigibilidade / Condução do veículo *

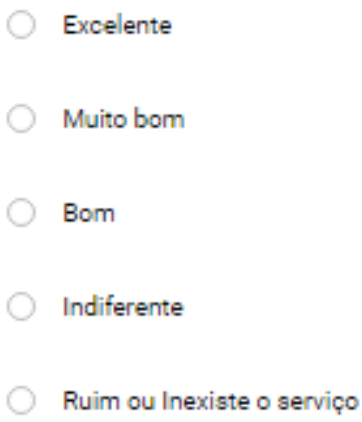

Gentileza e empatia no trato verbal (Ex.: cumprimentar, dar bom dia...) *

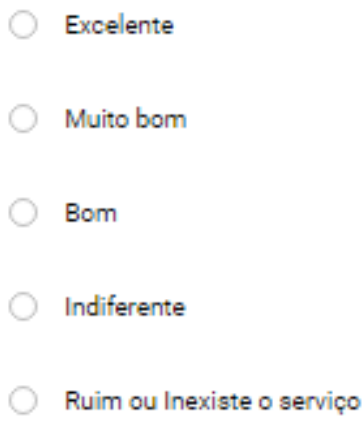

Prestatividade para ações físicas (abrir a porta, carregar mala, ajudar idoso a entrar no veículo...)

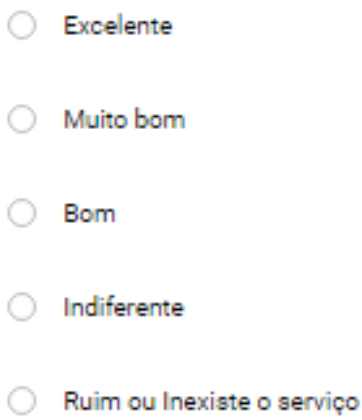

Higiene Pessoal (Ex.: não apresentar mau cheiro, mau hálito, com barba feita...)

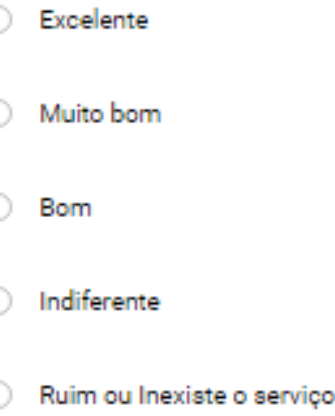


Acesso a uma segunda língua (capacidade de se comunicar em outro idioma) * Se a comunicação em outra língua for irrelevante para você na escolha do transporte no DF, marque "indiferente". Caso entenda que o serviço não disponibiliza essa opção, marque "ruim ou inexiste o serviço".

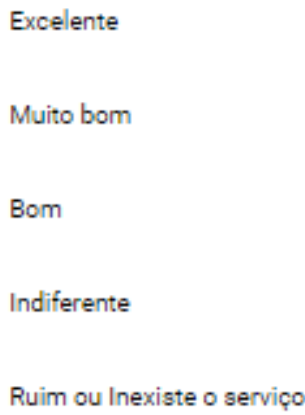

Seção 3 de 10

\section{CONHECIMENTO DO TRAJETO}

Descrição (opcional)

Sugestão de trajetos possiveis pelo taxista *

Excelente

Muito bom

Bom

Indiferente

Ruim ou Inexiste o serviço

Capacidade para solucionar problemas de tráfego (rotas alternativas, desvios...)

Excelente

Muito bom

Bom

Indiferente

Ruim ou Inexiste o serviço 
Pontualidade para chegar ao destino *

Excelente

Muito bom

Bom

Indiferente

Ruim ou Inexiste o serviço

\title{
Seção 4 de 10
}

\section{Conforto do Veículo}

Descrição (opcional)

\author{
Espaço interno adequado * \\ Excelente \\ Muito bom \\ Bom \\ Indiferente \\ Ruim ou Inexiste o serviço
}

Ambiente agradável *
Excelente
Muito bom
Bom
Indiferente
Ruim ou Inexiste o serviço 


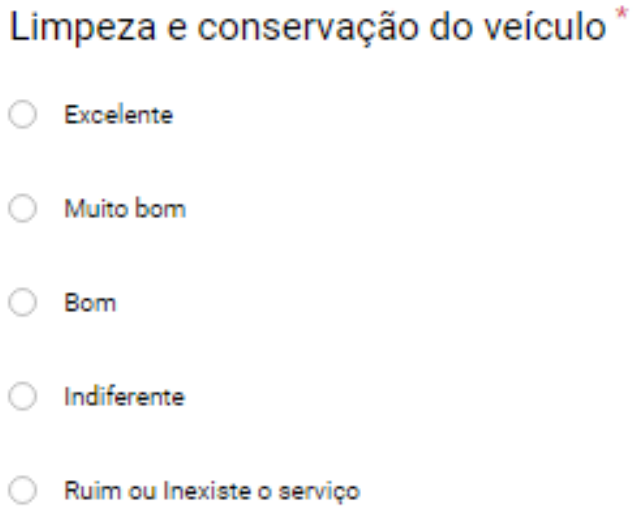

Serviço de bordo adicionais *
Excelente
Muito bom
Bom
Indiferente
Ruim ou Inexiste o serviço

\section{Espaço do porta-malas *}

Excelente

Muito bom

Bom

Indiferente

Ruim ou Inexiste o serviço

\section{Seção 5 de 10}

\section{Custo $\mathrm{x}$ benefício do serviço}




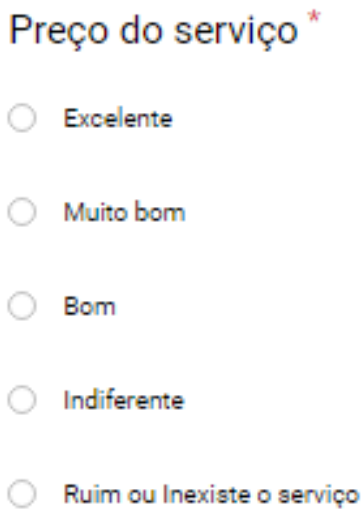

Facilidade de pagamento (Os meios de pagamento disponíveis te atenderam de forma satisfatória?)

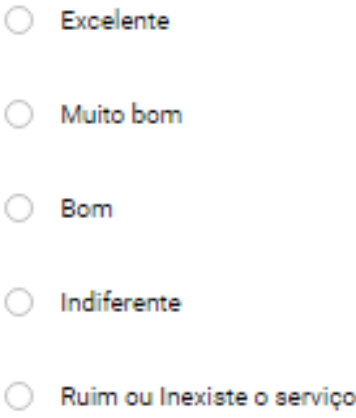

Controle do valor a ser pago na corrida (Ex.: ver o preço inicial e sua evolução * na viagem...)

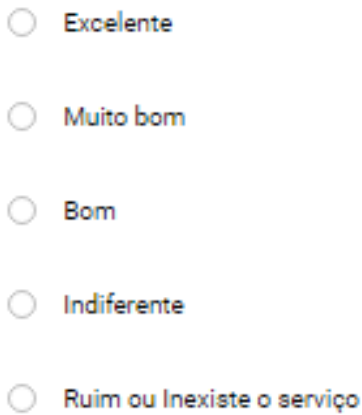

Transparência da forma de cálculo da tarifa *

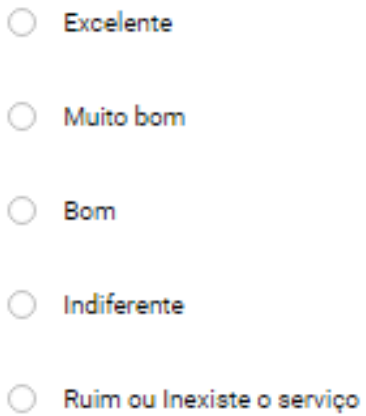




\section{Intangíveis e valor da marca}

Descrị̣ão (opcional)

Imagem da marca - Táxi (Qual é o valor da marca TÁXI para você? O quê vem à sua cabeça quando ouve falar na palavra TÁXI?)

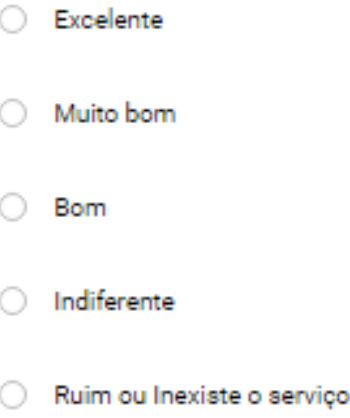

Percepção de valor do serviço (Qual é o valor atribuído ao serviço de Táxi? 0 quê vem à sua cabeça quando pensa no serviço Táxi e geral?)

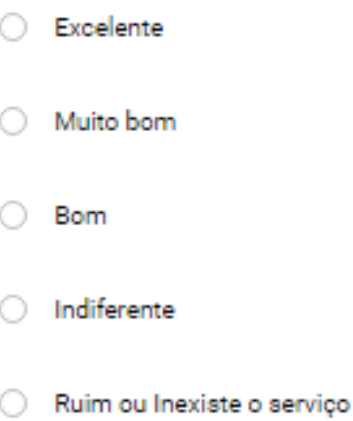


Facilidade de gerar o pedido do serviço *

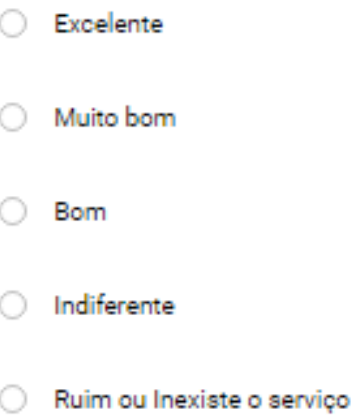

Abrangência de atendimento - Área atendida pelo serviço *

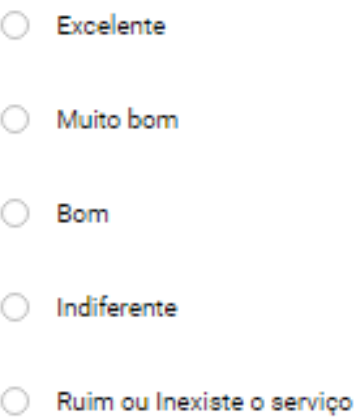

Adaptação à Pessoas com Necessidades Especiais - PNE (Avalie se há disponibilidade de serviços como carros do tipo Doblô para acomodar PNE? Acha que a quantidade é suficiente? Caso entenda que não exista ou a quantidade disponível é insuficiente, avalie "ruim ou inexistente o serviço". Se a existência desse tipo de serviço for indiferente na escolha do transporte, marque "indiferente".)

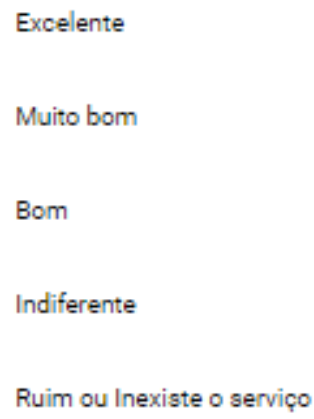

\section{Tempo}


Tempo de chegada após o pedido *

Excelente
Muito bom
Bom
Indiferente
Ruim ou Inexiste o serviço

Monitoramento da chegada após o pedido *

Excelente

Muito bom

Bom

Indiferente

Ruim ou Inexiste o serviço

Horário de funcionamento do serviço *

Excelente

Muito bom

Bom

Indiferente

Ruim ou Inexiste o serviço

Seção 9 de 10

Segurança e Confiabilidade

Descrị̧ão (opcional) 
Sensação de segurança ao adentrar no veículo - identificação do serviço *

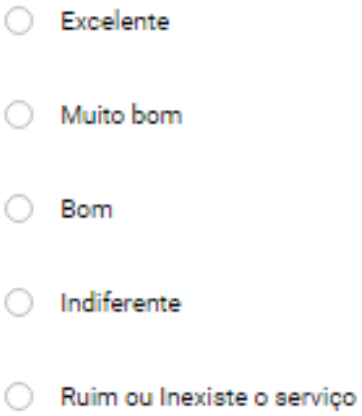

Itens de segurança do veículo (Ex.: cinto de segurança, airbag, seguro automotivo)

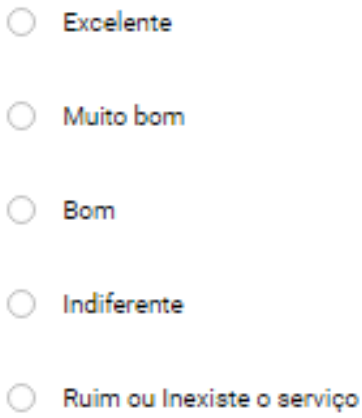

Privacidade em relação ao prestador de serviço (Ex.: respeito a gênero; indagação sobre informações pessoais, de estado civil, e-mail, número de telefone; diálogo invasivo...)

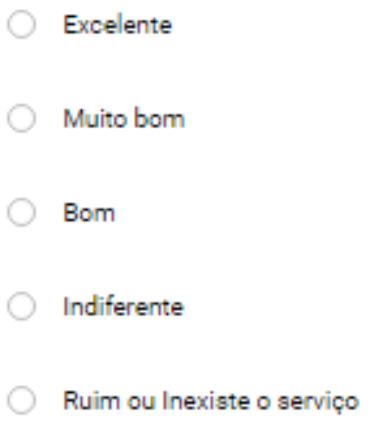


Confiabilidade - disponibilidade de serviço quando necessário *

Excelente

Muito bom

Bom

Indiferente

Ruim ou Inexiste o serviço

\section{Seção 10 de 10}

\section{Sistema de Apoio}

Descrição (opcional)

Serviço de atendimento ao usuários - dúvidas (Ex.: existe sistema disponível para tirar dúvidas? É eficiente? De fácil utilização?)
Excelente
Muito bom
Bom
Indiferente
Ruim ou Inexiste o serviço

Atendimento "pós venda" e reclamações (Ex.: existe sistema de avaliação do serviço/reclamação disponível? Atinge o objetivo? É de fácil utilização?)
Excelente
Muito bom
Bom
Indiferente
Ruim ou Inexiste o serviço 
APÊNDICE F - MATRIZES SEMÂNTICAS E POSIÇÃO DA MEDIANA (TÁXI)

\begin{tabular}{|c|c|c|c|c|c|c|c|c|c|c|}
\hline \multicolumn{11}{|c|}{ TÁXI } \\
\hline Obj. Estudo & \multicolumn{5}{|c|}{ 1.1.1 Dirigibilidade / Condução do Veículo } & \multirow{2}{*}{$\begin{array}{l}\text { Opções } \\
\text { Mediana }\end{array}$} & \multirow{2}{*}{$\begin{array}{l}\text { Opções } \\
\text { Modelo }\end{array}$} & \multirow{2}{*}{$\begin{array}{r}\text { Nível } \\
\text { Impact }\end{array}$} & \multirow{2}{*}{$\begin{array}{l}\text { Marque } \\
\text { Com->x }\end{array}$} & \multirow[t]{2}{*}{ Escala } \\
\hline$\underline{0}$ & Excel & MBom & Bom & Indifere & Ruim/in & & & & & \\
\hline Excel & Nulo & Forte & M for/Fort & MuitoForte & Extr/M fort & Ótimo & Excel & N5 & & 155 \\
\hline M Bom & & Nulo & Fort/M ode & Forte & M for/Fort & $\mathrm{BOM}$ & MBom & $* N 4 *$ & & 100 \\
\hline Bom & Esfor & ços & Nulo & Moderado & Fort/M ode & Regular & Bom & N3 & $x$ & 47 \\
\hline Indifere & Atrib & uídos & & Nulo & Mode/Frac & NEUTRO & Indifere & *N2* & & 0 \\
\hline Ruim/in & & & & & Nulo & Negativo & Ruim/in & N1 & & -41 \\
\hline & & & & & & \multicolumn{3}{|c|}{ Posição da Mediana: } & N3 & 47 \\
\hline
\end{tabular}

\begin{tabular}{|c|c|c|c|c|c|c|c|c|c|c|}
\hline \multirow{2}{*}{$\begin{array}{c}\text { Obj. Estudo } \\
\underline{0}\end{array}$} & \multicolumn{5}{|c|}{ 1.1.2 Gentileza e Empatia no trato verbal } & \multirow{2}{*}{$\begin{array}{l}\text { Opções } \\
\text { Mediana }\end{array}$} & \multirow{2}{*}{$\begin{array}{l}\text { Opções } \\
\text { Modelo }\end{array}$} & \multirow{2}{*}{$\begin{array}{l}\text { Nível } \\
\text { Impact }\end{array}$} & \multirow{2}{*}{$\begin{array}{l}\text { Marque } \\
\text { Com->x }\end{array}$} & \multirow[t]{2}{*}{ Escala } \\
\hline & Excel & M Bom & Bom & Indifere & Ruim/in & & & & & \\
\hline Excel & Nulo & M for/Fort & Muito Forte & Extr/M fort & Extremo & Ótimo & Excel & N5 & & 189 \\
\hline M Bom & & Nulo & M uito Forte & Extr/M fort & Extremo & $\mathrm{BOM}$ & MBom & *N4* & & 100 \\
\hline Bom & Esfor & ços & Nulo & M uito Fraca & Fraca & Regular & Bom & N3 & $x$ & 31 \\
\hline Indifere & Atrib & uídos & & Nulo & Muito Fraca & NEUTRO & Indifere & *N2* & & 0 \\
\hline Ruim/in & & & & & Nulo & Negativo & Ruim/in & N1 & & -88 \\
\hline & & & & & & Posição da & Mediana & & N3 & 31 \\
\hline
\end{tabular}

\begin{tabular}{|c|c|c|c|c|c|c|c|c|c|c|}
\hline \multirow{2}{*}{$\begin{array}{c}\text { Obj. Estudo } \\
\underline{0}\end{array}$} & \multicolumn{5}{|c|}{ 1.1.3 Prestatividade para aç̃oes físicas } & \multirow{2}{*}{$\begin{array}{c}\text { Opções } \\
\text { Mediana }\end{array}$} & \multirow{2}{*}{$\begin{array}{l}\text { Opções } \\
\text { Modelo }\end{array}$} & \multirow{2}{*}{$\begin{array}{r}\text { Nível } \\
\text { Impact }\end{array}$} & \multirow{2}{*}{$\begin{array}{l}\text { Marque } \\
\text { Com->x }\end{array}$} & \multirow[t]{2}{*}{ Escala } \\
\hline & Excel & MBom & Bom & Indifere & Ruim/in & & & & & \\
\hline Excel & Nulo & Fraca & Mode/Frac & Moderado & Fort/Mode & Ótimo & Excel & N5 & & 118 \\
\hline M Bom & & Nulo & Fraca & Mode/Frac & Moderado & $\mathrm{BOM}$ & MBom & *N4* & & 100 \\
\hline Bom & Esfor & ços & Nulo & Fraca & Moderado & Regular & Bom & N3 & & 55 \\
\hline Indifere & Atrib & uídos & & Nulo & Frac/M frac & NEUTRO & Indifere & *N2* & $x$ & 0 \\
\hline Ruim/in & & & & & Nulo & Negativo & Ruim/in & N1 & & -12 \\
\hline & & & & & & Posição da & Mediana & & *N2* & 0 \\
\hline
\end{tabular}

\begin{tabular}{|c|c|c|c|c|c|c|c|c|c|c|}
\hline \multirow{2}{*}{$\begin{array}{c}\text { Obj. Estudo } \\
\underline{0}\end{array}$} & \multicolumn{5}{|c|}{ 1.1.4 Higiene Pessoal } & \multirow{2}{*}{$\begin{array}{c}\text { Opções } \\
\text { Mediana }\end{array}$} & \multirow{2}{*}{$\begin{array}{l}\text { Opções } \\
\text { Modelo }\end{array}$} & \multirow{2}{*}{$\begin{array}{r}\text { Nível } \\
\text { Impact }\end{array}$} & \multirow{2}{*}{$\begin{array}{l}\text { Marque } \\
\text { Com->X }\end{array}$} & \multirow[t]{2}{*}{ Escala } \\
\hline & Excel & MBom & Bom & Indifere & Ruim/in & & & & & \\
\hline Excel & Nulo & Mode/Frac & Fort/M ode & Forte & M for/Fort & Ótimo & Excel & N5 & & 133 \\
\hline M Bom & & Nulo & Fraca & Moderado & Fort/M ode & $\mathrm{BOM}$ & MBom & $* N 4^{*}$ & & 100 \\
\hline Bom & Esfor & ç०S & Nulo & Mode/Frac & Moderado & Regular & Bom & N3 & $x$ & 55 \\
\hline Indifere & Atrib & uídos & & Nulo & Fraca & NEUTRO & Indifere & *N2* & & 0 \\
\hline Ruim/in & & & & & Nulo & Negativo & Ruim/in & N1 & & -21 \\
\hline & & & & & & Posição da & Mediana: & & N3 & 55 \\
\hline
\end{tabular}

\begin{tabular}{|c|c|c|c|c|c|c|c|c|c|c|}
\hline \multirow{2}{*}{$\begin{array}{c}\text { Obj. Estudo } \\
\underline{0}\end{array}$} & \multicolumn{5}{|c|}{$\underline{1.1 .5}$ Acesso à segunda língua } & \multirow{2}{*}{$\begin{array}{c}\text { Opções } \\
\text { Mediana }\end{array}$} & \multirow{2}{*}{$\begin{array}{l}\text { Opções } \\
\text { Modelo }\end{array}$} & \multirow{2}{*}{$\begin{array}{l}\text { Nível } \\
\text { Impact }\end{array}$} & \multirow{2}{*}{$\begin{array}{l}\text { Marque } \\
\text { Com->x }\end{array}$} & \multirow[t]{2}{*}{ Escala } \\
\hline & Excel & MBom & Bom & Indifere & Ruim/in & & & & & \\
\hline Excel & Nulo & M for/Fort & M uito Forte & Extr/M fort & Extremo & Ótimo & Excel & N5 & & 166 \\
\hline M Bom & & Nulo & MuitoForte & Extr/M fort & Extremo & BOM & MBom & *N4* & & 100 \\
\hline Bom & Esfor & ços & Nulo & Moderado & Fort/M ode & Regular & Bom & N3 & & 38 \\
\hline Indifere & Atrib & uídos & & Nulo & Mode/Frac & NEUTRO & Indifere & *N2* & $x$ & 0 \\
\hline Ruim/in & & & & & Nulo & Negativo & Ruim/in & N1 & & -68 \\
\hline & & & & & & Posição da & Mediana & & *N2* & 0 \\
\hline
\end{tabular}




\begin{tabular}{|c|c|c|c|c|c|c|c|c|c|c|}
\hline \multirow{2}{*}{$\begin{array}{c}\text { Obj. Estudo } \\
\underline{0} \\
\end{array}$} & \multicolumn{5}{|c|}{ 1.2.1 Sugestão de Trajetos Possíveis } & \multirow{2}{*}{$\begin{array}{c}\text { Opções } \\
\text { Mediana }\end{array}$} & \multirow{2}{*}{$\begin{array}{l}\text { Opções } \\
\text { Modelo }\end{array}$} & \multirow{2}{*}{\begin{tabular}{|r} 
Nível \\
Impact \\
\end{tabular}} & \multirow{2}{*}{$\begin{array}{l}\text { Marque } \\
\text { Com->x }\end{array}$} & \multirow[t]{2}{*}{ Escala } \\
\hline & Excel & MBom & Bom & Indifere & Ruim/in & & & & & \\
\hline Excel & Nulo & Fort/Mode & Forte & M for/Fort & M uito Forte & Ótimo & Excel & N5 & & 143 \\
\hline M Bom & & Nulo & Moderado & Fort/Mode & M for/Fort & BOM & MBom & $* N 4 *$ & & 100 \\
\hline Bom & Esfor & ç०S & Nulo & M o derado & Fort/M o de & Regular & Bom & N3 & & 50 \\
\hline Indifere & Atrib & uídos & & Nulo & Mode/Frac & NEUTRO & Indifere & *N2* & $x$ & 0 \\
\hline Ruim/in & & & & & Nulo & Negativo & Ruim/in & N1 & & -32 \\
\hline & & & & & & \multicolumn{3}{|c|}{ Posição da Mediana: } & *N2* & 0 \\
\hline
\end{tabular}

\begin{tabular}{|c|c|c|c|c|c|c|c|c|c|c|}
\hline \multirow{2}{*}{$\begin{array}{c}\text { Obj. Estudo } \\
\underline{0}\end{array}$} & \multicolumn{5}{|c|}{ 1.2.2 Proatividade para solucionar prob tráfego } & \multirow{2}{*}{$\begin{array}{c}\text { Opções } \\
\text { Mediana }\end{array}$} & \multirow{2}{*}{$\begin{array}{l}\text { Opções } \\
\text { Modelo }\end{array}$} & \multirow{2}{*}{$\begin{array}{r}\text { Nível } \\
\text { Impact }\end{array}$} & \multirow{2}{*}{$\begin{array}{l}\text { Marque } \\
\text { Com->x }\end{array}$} & \multirow[t]{2}{*}{ Escala } \\
\hline & Excel & M Bom & Bom & Indifere & Ruim/in & & & & & \\
\hline Excel & Nulo & M for/Fort & M uito Forte & Extr/M fort & Extremo & Ótimo & Excel & N5 & & 189 \\
\hline M Bom & & Nulo & Forte & M for/Fort & M uitoForte & $\mathrm{BOM}$ & MBom & $* N 4 *$ & & 100 \\
\hline Bom & Es f or & ç O S & Nulo & MuitoFraca & Frac/M frac & Regular & Bom & N3 & $x$ & 30 \\
\hline Indifere & Atrib & uíd os & & Nulo & Frac/M frac & NEUTRO & Indifere & *N2* & & 0 \\
\hline Ruim/in & & & & & Nulo & Negativo & Ruim/in & N1 & & -76 \\
\hline & & & & & & Posição da & Mediana & & N3 & 30 \\
\hline
\end{tabular}

\begin{tabular}{|c|c|c|c|c|c|c|c|c|c|c|}
\hline \multirow{2}{*}{$\begin{array}{c}\text { Obj. Estudo } \\
\underline{0} \\
\end{array}$} & \multicolumn{5}{|c|}{ 1.2.3 Pontualidade para chegar ao destino } & \multirow{2}{*}{$\begin{array}{l}\text { Opções } \\
\text { Mediana }\end{array}$} & \multirow{2}{*}{$\begin{array}{l}\text { Opções } \\
\text { Modelo }\end{array}$} & \multirow{2}{*}{$\begin{array}{r}\text { Nível } \\
\text { Impact }\end{array}$} & \multirow{2}{*}{$\begin{array}{l}\text { Marque } \\
\text { Com->x }\end{array}$} & \multirow[t]{2}{*}{ Escala } \\
\hline & Excel & M Bom & Bom & Indifere & Ruim/in & & & & & \\
\hline Excel & Nulo & M for/Fort & M uito Forte & Extr/M fort & Extremo & Ótimo & Excel & N5 & & 165 \\
\hline M Bom & & Nulo & M for/Fort & M uitoForte & Extr/M fort & BOM & MBom & $* N 4 *$ & & 100 \\
\hline Bom & Esfor & ç०S & Nulo & Fort/M o de & Forte & Regular & Bom & N3 & $x$ & 45 \\
\hline Indifere & Atrib & uídos & & Nulo & Fraca & NEUTRO & Indifere & *N2* & & 0 \\
\hline Ruim/in & & & & & Nulo & Negativo & Ruim/in & N1 & & -55 \\
\hline & & & & & & Posição da & Mediana & & N3 & 45 \\
\hline
\end{tabular}

\begin{tabular}{|c|c|c|c|c|c|c|c|c|c|c|}
\hline \multirow{2}{*}{$\begin{array}{c}\text { Obj. Estudo } \\
\underline{0}\end{array}$} & \multicolumn{5}{|c|}{ 1.3.1 Espaço Interno Adequado } & \multirow{2}{*}{$\begin{array}{c}\text { Opções } \\
\text { Mediana }\end{array}$} & \multirow{2}{*}{$\begin{array}{l}\text { Opções } \\
\text { Modelo }\end{array}$} & \multirow{2}{*}{$\begin{array}{r}\text { Nível } \\
\text { Impact }\end{array}$} & \multirow{2}{*}{$\begin{array}{l}\text { Marque } \\
\text { Com->x }\end{array}$} & \multirow[t]{2}{*}{ Escala } \\
\hline & Excel & M Bom & Bom & Indifere & Ruim/in & & & & & \\
\hline Excel & Nulo & M for/Fort & M uito Forte & Extr/M fort & Extremo & Ótimo & Excel & N5 & & 177 \\
\hline M Bom & & Nulo & Muito Forte & Extr/M fort & Extremo & $\mathrm{BOM}$ & MBom & *N4* & & 100 \\
\hline Bom & Esfor & ços & Nulo & Fraca & Mode/Frac & Regular & Bom & N3 & $x$ & 33 \\
\hline Indifere & Atrib & uídos & & Nulo & Fraca & NEUTRO & Indifere & $* N 2 *$ & & 0 \\
\hline Ruim/in & & & & & Nulo & Negativo & Ruim/in & N1 & & -79 \\
\hline & & & & & & Posição da & Mediana & & N3 & 33 \\
\hline
\end{tabular}

\begin{tabular}{|c|c|c|c|c|c|c|c|c|c|c|}
\hline \multirow{2}{*}{$\begin{array}{c}\text { Obj. Estudo } \\
\underline{0} \\
\end{array}$} & \multicolumn{5}{|c|}{ 1.3.2 Ambiente agradável } & \multirow{2}{*}{\begin{tabular}{|c|} 
Opções \\
Mediana \\
\end{tabular}} & \multirow{2}{*}{$\begin{array}{l}\text { Opções } \\
\text { Modelo } \\
\end{array}$} & \multirow{2}{*}{$\begin{array}{r}\begin{array}{r}\text { Nível } \\
\text { Impact }\end{array} \\
\end{array}$} & \multirow{2}{*}{\begin{tabular}{|l} 
Marque \\
Com->x
\end{tabular}} & \multirow[t]{2}{*}{ Escala } \\
\hline & Excel & M Bom & Bom & Indifere & Ruim/in & & & & & \\
\hline Excel & Nulo & M o derado & Fort/M ode & Forte & M uito F orte & Ótimo & Excel & N5 & & 132 \\
\hline M Bom & & Nulo & Fort/M ode & Forte & M for/Fort & $\mathrm{BOM}$ & MBom & $* N 4 *$ & & 100 \\
\hline Bom & Esfor & ços & Nulo & Moderado & Fort/M ode & Regular & Bom & N3 & $x$ & 48 \\
\hline Indifere & Atrib & uíd os & & Nulo & Fraca & NEUTRO & Indifere & $* \mathrm{~N} 2 *$ & & 0 \\
\hline Ruim/in & & & & & Nulo & Negativo & Ruim/in & $\mathrm{N} 1$ & & -33 \\
\hline & & & & & & \multicolumn{3}{|c|}{ Posição da Mediana: } & N3 & 48 \\
\hline
\end{tabular}




\begin{tabular}{|c|c|c|c|c|c|c|c|c|c|c|}
\hline \multirow{2}{*}{$\begin{array}{c}\text { Obj. Estudo } \\
\underline{0}\end{array}$} & \multicolumn{5}{|c|}{$\underline{\underline{1} \text { 1.3.3 Limpeza e conservacãó }}$} & \multirow{2}{*}{$\begin{array}{l}\text { Opções } \\
\text { Mediana }\end{array}$} & \multirow{2}{*}{$\begin{array}{l}\text { Opções } \\
\text { Modelo }\end{array}$} & \multirow{2}{*}{$\begin{array}{r}\text { Nível } \\
\text { Impact }\end{array}$} & \multirow{2}{*}{$\begin{array}{l}\text { Marque } \\
\text { Com->x }\end{array}$} & \multirow[t]{2}{*}{ Escala } \\
\hline & Excel & M Bom & Bom & Indifere & Ruim/in & & & & & \\
\hline Excel & Nulo & Fraca & M ode/Frac & Mo oderado & Forte & Ótimo & Excel & N5 & & 121 \\
\hline M B om & & Nulo & Fraca & Mode/Frac & M oderado & BOM & MBom & $* N 4 *$ & & 100 \\
\hline Bom & Esfor & ços & Nulo & Fraca & Mode/Frac & Regular & Bom & N3 & $x$ & 52 \\
\hline Indifere & Atrib & uídos & & Nulo & Frac/M frac & NEUTRO & Indifere & *N2* & & 0 \\
\hline Ruim/in & & & & & Nulo & Negativo & Ruim/in & N1 & & -15 \\
\hline & & & & & & \multicolumn{3}{|c|}{ Posição da Mediana: } & N3 & 52 \\
\hline
\end{tabular}

\begin{tabular}{|c|c|c|c|c|c|c|c|c|c|c|}
\hline \multirow{2}{*}{$\begin{array}{c}\text { Obj. Estudo } \\
\underline{0}\end{array}$} & \multicolumn{5}{|c|}{ 1.3.4 Serviços de bordo adicionais } & \multirow{2}{*}{$\begin{array}{l}\text { Opções } \\
\text { Mediana }\end{array}$} & \multirow{2}{*}{$\begin{array}{l}\text { Opções } \\
\text { Modelo }\end{array}$} & \multirow{2}{*}{$\begin{array}{r}\text { Nível } \\
\text { Impact }\end{array}$} & \multirow{2}{*}{$\begin{array}{l}\text { Marque } \\
\text { Com->x }\end{array}$} & \multirow[t]{2}{*}{ Escala } \\
\hline & Excel & M Bom & Bom & Indifere & Ruim/in & & & & & \\
\hline Excel & Nulo & Frac/M frac & Fraca & Mode/Frac & Moderado & Ótimo & Excel & N5 & & 115 \\
\hline M Bom & & Nulo & Frac/M frac & Fraca & M ode/Frac & BOM & MBom & *N4* & & 100 \\
\hline Bom & Esfor & ç०S & Nulo & Frac/M frac & Fraca & Regular & Bom & N3 & & 48 \\
\hline Indifere & Atrib & u íd os & & Nulo & Fraca & NEUTRO & Indifere & *N2* & & 0 \\
\hline Ruim/in & & & & & Nulo & Negativo & Ruim/in & N1 & $x$ & -11 \\
\hline & & & & & & Posição da & Mediana & & N1 & -11 \\
\hline
\end{tabular}

\begin{tabular}{|c|c|c|c|c|c|c|c|c|c|c|}
\hline \multirow{2}{*}{$\begin{array}{c}\text { Obj. Estudo } \\
\underline{0}\end{array}$} & \multicolumn{5}{|c|}{ 1.3.5 Espaço do porta-malas } & \multirow{2}{*}{$\begin{array}{l}\text { Opções } \\
\text { Mediana }\end{array}$} & \multirow{2}{*}{$\begin{array}{l}\text { Opções } \\
\text { Modelo }\end{array}$} & \multirow{2}{*}{$\begin{array}{r}\text { Nível } \\
\text { Impact }\end{array}$} & \multirow{2}{*}{$\begin{array}{l}\text { Marque } \\
\text { Com->x }\end{array}$} & \multirow[t]{2}{*}{ Escala } \\
\hline & Excel & M Bom & Bom & Indifere & Ruim/in & & & & & \\
\hline Excel & Nulo & M for/Fort & M uitoForte & Extr/M fort & Extremo & Ótimo & Excel & N5 & & 158 \\
\hline M Bom & & Nulo & M for/Fort & M uitoForte & Extr/M fort & BOM & MBom & *N4* & & 100 \\
\hline Bom & Es for & ç०s & Nulo & Forte & M for/Fort & Regular & Bom & N3 & $x$ & 47 \\
\hline Indifere & Atrib & uíd os & & Nulo & Fort/M o de & NEUTRO & Indifere & $* \mathrm{~N} 2 *$ & & 0 \\
\hline Ruim/in & & & & & Nulo & Negativo & Ruim/in & N1 & & -52 \\
\hline & & & & & & Posição d & Mediana & & N3 & 47 \\
\hline
\end{tabular}

\begin{tabular}{|c|c|c|c|c|c|c|c|c|c|c|}
\hline \multirow{2}{*}{$\begin{array}{c}\text { Obj. Estudo } \\
\underline{0}\end{array}$} & \multicolumn{5}{|c|}{ 2.1.1 Preço do Serviço } & \multirow{2}{*}{$\begin{array}{c}\text { Opções } \\
\text { Mediana }\end{array}$} & \multirow{2}{*}{$\begin{array}{l}\text { Opções } \\
\text { Modelo }\end{array}$} & \multirow{2}{*}{$\begin{array}{l}\text { Nível } \\
\text { Impact }\end{array}$} & \multirow{2}{*}{$\begin{array}{l}\text { Marque } \\
\text { Com->x }\end{array}$} & \multirow[t]{2}{*}{ Escala } \\
\hline & Excel & M Bom & Bom & Indifere & Ruim/in & & & & & \\
\hline Excel & Nulo & M for/Fort & M uitoForte & Extr/M fort & Extremo & Ótimo & Excel & N5 & & 185 \\
\hline M Bom & & Nulo & M uitoForte & Extr/M fort & Extremo & $\mathrm{BOM}$ & MBom & *N4* & & 100 \\
\hline Bom & Esfor & ç०S & Nulo & Frac/M frac & Fraca & Regular & Bom & N3 & & 32 \\
\hline Indifere & Atrib & uíd os & & Nulo & M uito Fraca & NEUTRO & Indifere & *N2* & & 0 \\
\hline Ruim/in & & & & & Nulo & Negativo & Ruim/in & N1 & $x$ & -84 \\
\hline & & & & & & Posição da & Mediana: & & N1 & -84 \\
\hline
\end{tabular}

\begin{tabular}{|c|c|c|c|c|c|c|c|c|c|c|}
\hline \multirow{2}{*}{$\begin{array}{c}\text { Obj. Estudo } \\
\underline{0} \\
\end{array}$} & \multicolumn{5}{|c|}{ 2.1.2 Facilidade (formas) de pagamento } & \multirow{2}{*}{$\begin{array}{c}\text { Opções } \\
\text { Mediana }\end{array}$} & \multirow{2}{*}{$\begin{array}{l}\text { Opções } \\
\text { Modelo }\end{array}$} & \multirow{2}{*}{$\begin{array}{r}\text { Nível } \\
\text { Impact }\end{array}$} & \multirow{2}{*}{$\begin{array}{l}\text { Marque } \\
\text { Com->x }\end{array}$} & \multirow[t]{2}{*}{ Escala } \\
\hline & Excel & M Bom & Bom & Indifere & Ruim/in & & & & & \\
\hline Excel & Nulo & Fort/M ode & Forte & M for/Fort & Extr/M fort & Ótimo & Excel & N5 & & 146 \\
\hline M Bom & & Nulo & Fort/M ode & Forte & M for/Fort & $\mathrm{BOM}$ & MBom & $* \mathrm{~N} 4 *$ & & 100 \\
\hline Bom & Es for & $c ̧ \circ \mathrm{S}$ & Nulo & Mo oderado & Forte & Regular & Bom & N3 & & 50 \\
\hline Indifere & Atrib & uíd os & & Nulo & Fraca & NEUTRO & Indifere & *N2* & & 0 \\
\hline Ruim/in & & & & & Nulo & Negativo & Ruim/in & N1 & $x$ & -36 \\
\hline & & & & & & \multicolumn{3}{|c|}{ Posição da Mediana: } & N1 & -36 \\
\hline
\end{tabular}




\begin{tabular}{|c|c|c|c|c|c|c|c|c|c|c|}
\hline \multirow{2}{*}{$\begin{array}{c}\text { Obj. Estudo } \\
\underline{0}\end{array}$} & \multicolumn{5}{|c|}{$\underline{2.1 .3 \text { Controle do valor a ser pago na corrida }}$} & \multirow{2}{*}{$\begin{array}{l}\text { Opções } \\
\text { Mediana }\end{array}$} & \multirow{2}{*}{$\begin{array}{l}\text { Opções } \\
\text { Modelo }\end{array}$} & \multirow{2}{*}{$\begin{array}{r}\text { Nível } \\
\text { Impact } \\
\end{array}$} & \multirow{2}{*}{$\begin{array}{l}\text { Marque } \\
\text { Com->x }\end{array}$} & \multirow[t]{2}{*}{ Escala } \\
\hline & Excel & M Bom & Bom & Indifere & Ruim/in & & & & & \\
\hline Excel & Nulo & Mode/Frac & Moderado & Fort/M o de & Forte & Ótimo & Excel & N5 & & 127 \\
\hline M B om & & Nulo & Fraca & Mode/Frac & Moderado & BOM & MBom & $* N 4 *$ & & 100 \\
\hline Bom & Es f or & ç O S & Nulo & Mode/Frac & M o derado & Regular & Bom & N3 & $x$ & 58 \\
\hline Indifere & Atrib & uíd os & & Nulo & Fraca & NEUTRO & Indifere & *N2* & & 0 \\
\hline Ruim/in & & & & & Nulo & Negativo & Ruim/in & N1 & & -14 \\
\hline & & & & & & Posição da & Mediana & & N3 & 58 \\
\hline
\end{tabular}

\begin{tabular}{|c|c|c|c|c|c|c|c|c|c|c|}
\hline \multirow{2}{*}{$\begin{array}{c}\text { Obj. Estudo } \\
\underline{0}\end{array}$} & \multicolumn{5}{|c|}{ 2.1.4 Transparência da fórmula de cálculo da tarifa } & \multirow{2}{*}{\begin{tabular}{|c|} 
Opções \\
Mediana \\
\end{tabular}} & \multirow{2}{*}{$\begin{array}{l}\text { Opções } \\
\text { Modelo }\end{array}$} & \multirow{2}{*}{$\begin{array}{r}\text { Nível } \\
\text { Impact } \\
\end{array}$} & \multirow{2}{*}{$\begin{array}{l}\text { Marque } \\
\text { Com->x }\end{array}$} & \multirow[t]{2}{*}{ Escala } \\
\hline & Excel & M Bom & Bom & Indifere & Ruim/in & & & & & \\
\hline Excel & Nulo & M for/Fort & M uito Forte & Extr/M fort & Extremo & Ótimo & Excel & N5 & & 166 \\
\hline M B om & & Nulo & M for/Fort & M uito Forte & Extr/M fort & $\mathrm{BOM}$ & MBom & $* N 4 *$ & & 100 \\
\hline Bom & Esfor & ç O S & Nulo & M o derado & Fort/M o de & Regular & Bom & N3 & & 39 \\
\hline Indifere & Atrib & uíd os & & Nulo & Moderado & NEUTRO & Indifere & $* \mathrm{~N} 2 *$ & & 0 \\
\hline Ruim/in & & & & & Nulo & Negativo & Ruim/in & N1 & $x$ & -61 \\
\hline & & & & & & Posição da & Mediana & & N1 & -61 \\
\hline
\end{tabular}

\begin{tabular}{|c|c|c|c|c|c|c|c|c|c|c|}
\hline \multirow{2}{*}{$\begin{array}{c}\text { Obj. Estudo } \\
\underline{0}\end{array}$} & \multicolumn{5}{|c|}{ 2.2.1 Imagem da Marca - TÁXI } & \multirow{2}{*}{$\begin{array}{c}\text { Opções } \\
\text { Mediana }\end{array}$} & \multirow{2}{*}{$\begin{array}{l}\text { Opções } \\
\text { Modelo }\end{array}$} & \multirow{2}{*}{$\begin{array}{r}\text { Nível } \\
\text { Impact } \\
\end{array}$} & \multirow{2}{*}{$\begin{array}{l}\text { Marque } \\
\text { Com->x }\end{array}$} & \multirow[t]{2}{*}{ Escala } \\
\hline & Excel & M Bom & Bom & Indifere & Ruim/in & & & & & \\
\hline Excel & Nulo & M for/Fort & M uito Forte & Extr/M fort & Extremo & Ótimo & Excel & N5 & & 191 \\
\hline M Bom & & Nulo & M uito Forte & Extr/M fort & Extremo & BOM & MBom & $* N 4 *$ & & 100 \\
\hline Bom & Esfor & ços & Nulo & M uitoFraca & Frac/M frac & Regular & Bom & N3 & & 30 \\
\hline Indifere & Atrib & uíd os & & Nulo & M uito Fraca & NEUTRO & Indifere & *N2* & $x$ & 0 \\
\hline Ruim/in & & & & & Nulo & Negativo & Ruim/in & N1 & & -91 \\
\hline & & & & & & Posição de & Mediana & & $* \mathrm{~N} 2 *$ & 0 \\
\hline
\end{tabular}

\begin{tabular}{|c|c|c|c|c|c|c|c|c|c|c|}
\hline \multirow{2}{*}{$\begin{array}{c}\text { Obj. Estudo } \\
\underline{0} \\
\end{array}$} & \multicolumn{5}{|c|}{$\underline{\text { 2.2.2 Percepção de valor do serviço }}$} & \multirow{2}{*}{$\begin{array}{c}\text { Opções } \\
\text { Mediana }\end{array}$} & \multirow{2}{*}{$\begin{array}{l}\text { Opções } \\
\text { Modelo }\end{array}$} & \multirow{2}{*}{$\begin{array}{r}\text { Nível } \\
\text { Impact } \\
\end{array}$} & \multirow{2}{*}{$\begin{array}{l}\text { Marque } \\
\text { Com->x }\end{array}$} & \multirow[t]{2}{*}{ Escala } \\
\hline & Excel & M Bom & Bom & Indifere & Ruim/in & & & & & \\
\hline Excel & Nulo & M for/Fort & M uito Forte & Extr/M fort & Extremo & Ótimo & Excel & N5 & & 178 \\
\hline M Bom & & Nulo & Forte & M for/Fort & M uitoForte & BOM & MBom & $* N 4 *$ & & 100 \\
\hline Bom & Es for & ç OS & Nulo & Fraca & Moderado & Regular & Bom & N3 & & 38 \\
\hline Indifere & Atrib & uídos & & Nulo & Frac/M frac & NEUTRO & Indifere & *N2* & $x$ & 0 \\
\hline Ruim/in & & & & & Nulo & Negativo & Ruim/in & N1 & & -62 \\
\hline & & & & & & \multicolumn{3}{|c|}{ Posição da Mediana: } & $* \mathrm{~N} 2 *$ & 0 \\
\hline
\end{tabular}

\begin{tabular}{|c|c|c|c|c|c|c|c|c|c|c|}
\hline \multirow{2}{*}{$\begin{array}{c}\text { Obj. Estudo } \\
\underline{0}\end{array}$} & \multicolumn{5}{|c|}{$\underline{\text { 3.1.1 Facilidade de Gerar Pedido do Serviço }}$} & \multirow{2}{*}{$\begin{array}{c}\text { Opções } \\
\text { Mediana }\end{array}$} & \multirow{2}{*}{$\begin{array}{l}\text { Opções } \\
\text { Modelo }\end{array}$} & \multirow{2}{*}{$\begin{array}{c}\text { Nível } \\
\text { Impact }\end{array}$} & \multirow{2}{*}{$\begin{array}{l}\text { Marque } \\
\text { Com->x }\end{array}$} & \multirow[t]{2}{*}{ Escala } \\
\hline & Excel & M Bom & Bom & Indifere & Ruim/in & & & & & \\
\hline Excel & Nulo & Moderado & Forte & M for/Fort & M uito Forte & Ótimo & Excel & N5 & & 139 \\
\hline M Bom & & Nulo & M o derado & Fort/M ode & Forte & BOM & MBom & *N4* & & 100 \\
\hline Bom & Es f or & ç O S & Nulo & Moderado & Fort/M ode & Regular & Bom & N3 & $x$ & 50 \\
\hline Indifere & Atrib & uíd o s & & Nulo & Mode/Frac & NEUTRO & Indifere & *N2* & & 0 \\
\hline Ruim/in & & & & & Nulo & Negativo & Ruim/in & N1 & & -31 \\
\hline & & & & & & Posição da & Mediana & & N3 & 50 \\
\hline
\end{tabular}




\begin{tabular}{|c|c|c|c|c|c|c|c|c|c|c|}
\hline \multirow{2}{*}{$\begin{array}{c}\text { Obj. Estudo } \\
\underline{0} \\
\end{array}$} & \multicolumn{5}{|c|}{ 3.1.2 Abrangência de atendimento - Área } & \multirow{2}{*}{$\begin{array}{c}\text { Opções } \\
\text { Mediana } \\
\end{array}$} & \multirow{2}{*}{$\begin{array}{l}\text { Opções } \\
\text { Modelo }\end{array}$} & \multirow{2}{*}{$\begin{array}{r}\text { Nível } \\
\text { Impact }\end{array}$} & \multirow{2}{*}{$\begin{array}{l}\text { Marque } \\
\text { Com->x }\end{array}$} & \multirow[t]{2}{*}{ Escala } \\
\hline & Excel & M Bom & Bom & Indifere & Ruim/in & & & & & \\
\hline Excel & Nulo & M for/Fort & M uito Forte & Extr/M fort & Extremo & Ótimo & Excel & N5 & & 183 \\
\hline M Bom & & Nulo & M for/Fort & MuitoForte & Extr/M fort & $\mathrm{BOM}$ & MBom & $* N 4 *$ & & 100 \\
\hline Bom & Es for & ços & Nulo & Frac/M frac & Fraca & Regular & Bom & N3 & $x$ & 32 \\
\hline Indifere & Atrib & uíd os & & Nulo & Frac/M frac & NEUTRO & Indifere & $* \mathrm{~N} 2 *$ & & 0 \\
\hline Ruim/in & & & & & Nulo & Negativo & Ruim/in & N1 & & -77 \\
\hline & & & & & & Posição da & Mediana & & N3 & 32 \\
\hline
\end{tabular}

\begin{tabular}{|c|c|c|c|c|c|c|c|c|c|c|}
\hline \multirow{2}{*}{$\begin{array}{c}\text { Obj. Estudo } \\
\underline{0} \\
\end{array}$} & \multicolumn{5}{|c|}{ 3.1.3 Adaptação à Necessidades Especiais } & \multirow{2}{*}{$\begin{array}{c}\text { Opções } \\
\text { Mediana }\end{array}$} & \multirow{2}{*}{$\begin{array}{l}\text { Opções } \\
\text { Modelo }\end{array}$} & \multirow{2}{*}{$\begin{array}{r}\text { Nível } \\
\text { Impact }\end{array}$} & \multirow{2}{*}{$\begin{array}{l}\text { Marque } \\
\text { Com->x }\end{array}$} & \multirow[t]{2}{*}{ Escala } \\
\hline & Excel & M Bom & Bom & Indifere & Ruim/in & & & & & \\
\hline Excel & Nulo & M for/Fort & M uito Forte & Extr/M fort & Extremo & Ótimo & Excel & N5 & & 164 \\
\hline M B om & & Nulo & Forte & M for/Fort & M uito Forte & BOM & MBom & $* N 4 *$ & & 100 \\
\hline Bom & Es f or & ços & Nulo & Fort/M ode & Forte & Regular & Bom & N3 & & 47 \\
\hline Indifere & Atrib & uídos & & Nulo & M o derado & NEUTRO & Indifere & $* \mathrm{~N} 2 *$ & $x$ & 0 \\
\hline Ruim/in & & & & & Nulo & Negativo & Ruim/in & N1 & & -50 \\
\hline & & & & & & Posição d & Mediana & & $* N 2 *$ & 0 \\
\hline
\end{tabular}

\begin{tabular}{|c|c|c|c|c|c|c|c|c|c|c|}
\hline \multirow{2}{*}{$\begin{array}{c}\text { Obj. Estudo } \\
\underline{0}\end{array}$} & \multicolumn{5}{|c|}{ 3.2.1 Tempo de Chegada Após o Pedido } & \multirow{2}{*}{$\begin{array}{c}\text { Opções } \\
\text { Mediana }\end{array}$} & \multirow{2}{*}{$\begin{array}{l}\text { Opções } \\
\text { Modelo }\end{array}$} & \multirow{2}{*}{$\begin{array}{r}\text { Nível } \\
\text { Impact }\end{array}$} & \multirow{2}{*}{$\begin{array}{l}\text { Marque } \\
\text { Com->x }\end{array}$} & \multirow[t]{2}{*}{ Escala } \\
\hline & Excel & M Bom & Bom & Indifere & Ruim/in & & & & & \\
\hline Excel & Nulo & M for/Fort & M uitoForte & Extr/M fort & Extremo & Ótimo & Excel & N5 & & 178 \\
\hline M Bom & & Nulo & M for/Fort & M uito Forte & Extr/M fort & $\mathrm{BOM}$ & MBom & $* \mathrm{~N} 4 *$ & & 100 \\
\hline Bom & Esfor & ços & Nulo & Fraca & M ode/Frac & Regular & Bom & N3 & $x$ & 35 \\
\hline Indifere & Atrib & uídos & & Nulo & Frac/M frac & NEUTRO & Indifere & *N2* & & 0 \\
\hline Ruim/in & & & & & Nulo & Negativo & Ruim/in & N1 & & -71 \\
\hline & & & & & & \multicolumn{3}{|c|}{ Posição da Mediana: } & N3 & 35 \\
\hline
\end{tabular}

\begin{tabular}{|c|c|c|c|c|c|c|c|c|c|c|}
\hline \multirow{2}{*}{$\begin{array}{c}\text { Obj. Estudo } \\
\underline{0}\end{array}$} & \multicolumn{5}{|c|}{ 3.2.2 Monitoramento da chegada } & \multirow{2}{*}{$\begin{array}{c}\text { Opções } \\
\text { Mediana }\end{array}$} & \multirow{2}{*}{$\begin{array}{c}\text { Opções } \\
\text { Modelo }\end{array}$} & \multirow{2}{*}{$\begin{array}{r}\text { Nível } \\
\text { Impact }\end{array}$} & \multirow{2}{*}{$\begin{array}{l}\text { Marque } \\
\text { Com->x }\end{array}$} & \multirow[t]{2}{*}{ Escala } \\
\hline & Excel & M Bom & Bom & Indifere & Ruim/in & & & & & \\
\hline Excel & Nulo & M o derado & Fort/M ode & Forte & M for/Fort & Ótimo & Excel & N5 & & 128 \\
\hline M Bom & & Nulo & Fort/M ode & Forte & M for/Fort & $\mathrm{BOM}$ & MBom & $* \mathrm{~N} 4 *$ & & 100 \\
\hline Bom & Esfor & ços & Nulo & Moderado & Fort/M ode & Regular & Bom & N3 & & 48 \\
\hline Indifere & Atrib & uídos & & Nulo & Fraca & NEUTRO & Indifere & *N2* & $x$ & 0 \\
\hline Ruim/in & & & & & Nulo & Negativo & Ruim/in & N1 & & -31 \\
\hline & & & & & & Posição d & Mediana & & $* \mathrm{~N} 2 *$ & 0 \\
\hline
\end{tabular}

\begin{tabular}{|c|c|c|c|c|c|c|c|c|c|c|}
\hline \multirow{2}{*}{$\begin{array}{c}\text { Obj. Estudo } \\
\underline{0}\end{array}$} & \multicolumn{5}{|c|}{$\underline{\text { 3.2.3 Horário de funcionamento }}$} & \multirow{2}{*}{$\begin{array}{c}\text { Opções } \\
\text { Mediana }\end{array}$} & \multirow{2}{*}{$\begin{array}{l}\text { Opções } \\
\text { Modelo }\end{array}$} & \multirow{2}{*}{$\begin{array}{r}\text { Nível } \\
\text { Impact }\end{array}$} & \multirow{2}{*}{$\begin{array}{l}\text { Marque } \\
\text { Com->X }\end{array}$} & \multirow[t]{2}{*}{ Escala } \\
\hline & Excel & M Bom & Bom & Indifere & Ruim/in & & & & & \\
\hline Excel & Nulo & Forte & M for/Fort & M uito Forte & Extr/M fort & Ótimo & Excel & N5 & & 158 \\
\hline M Bom & & Nulo & Fort/M ode & Forte & M for/Fort & $\mathrm{BOM}$ & MBom & *N4* & & 100 \\
\hline Bom & Esfor & ç O S & Nulo & Mode/Frac & M oderado & Regular & Bom & N3 & $x$ & 41 \\
\hline Indifere & Atrib & uíd os & & Nulo & M ode/Frac & NEUTRO & Indifere & *N2* & & 0 \\
\hline Ruim/in & & & & & Nulo & Negativo & Ruim/in & N1 & & -46 \\
\hline & & & & & & Posição d & Mediana & & N3 & 41 \\
\hline
\end{tabular}




\begin{tabular}{|c|c|c|c|c|c|c|c|c|c|c|}
\hline \multirow{2}{*}{$\begin{array}{c}\text { Obj. Estudo } \\
\underline{0}\end{array}$} & \multicolumn{5}{|c|}{ 4.1.1 Sensação de Segurança-Identif. do Serviço } & \multirow{2}{*}{$\begin{array}{c}\text { Opções } \\
\text { Mediana }\end{array}$} & \multirow{2}{*}{$\begin{array}{l}\text { Opções } \\
\text { Modelo }\end{array}$} & \multirow{2}{*}{$\begin{array}{r}\text { Nível } \\
\text { Impact }\end{array}$} & \multirow{2}{*}{$\begin{array}{l}\text { Marque } \\
\text { Com->x }\end{array}$} & \multirow[t]{2}{*}{ Escala } \\
\hline & Excel & M Bom & Bom & Indifere & Ruim/in & & & & & \\
\hline Excel & Nulo & M for/Fort & M uito Forte & Extr/M fort & Extremo & Ótimo & Excel & N5 & & 173 \\
\hline M B om & & Nulo & Forte & M for/Fort & M uito Forte & BOM & MBom & *N4* & & 100 \\
\hline Bom & Esfor & ç०S & Nulo & Mode/Frac & Fort/M ode & Regular & Bom & N3 & $x$ & 41 \\
\hline Indifere & Atrib & uíd os & & Nulo & Fraca & NEUTRO & Indifere & *N2* & & 0 \\
\hline Ruim/in & & & & & Nulo & Negativo & Ruim/in & N1 & & -57 \\
\hline & & & & & & Posição d & Mediana & & N3 & 41 \\
\hline
\end{tabular}

\begin{tabular}{|c|c|c|c|c|c|c|c|c|c|c|}
\hline \multirow{2}{*}{$\begin{array}{c}\text { Obj. Estudo } \\
\underline{0}\end{array}$} & \multicolumn{5}{|c|}{ 4.1.2 Itens de segurança do veículo } & \multirow{2}{*}{$\begin{array}{l}\text { Opções } \\
\text { Mediana }\end{array}$} & \multirow{2}{*}{$\begin{array}{l}\text { Opções } \\
\text { Modelo }\end{array}$} & \multirow{2}{*}{$\begin{array}{c}\text { Nível } \\
\text { Impact }\end{array}$} & \multirow{2}{*}{$\begin{array}{l}\text { Marque } \\
\text { Com->x }\end{array}$} & \multirow[t]{2}{*}{ Escala } \\
\hline & Excel & M Bom & Bom & Indifere & Ruim/in & & & & & \\
\hline Excel & Nulo & Mode/Frac & Moderado & Fort/M ode & M for/Fort & Ótimo & Excel & N5 & & 127 \\
\hline M Bom & & Nulo & Mode/Frac & M o derado & Fort/M ode & $\mathrm{BOM}$ & MBom & *N4* & & 100 \\
\hline Bom & Esfor & ç O S & Nulo & Mode/Frac & Moderado & Regular & Bom & N3 & $x$ & 51 \\
\hline Indifere & Atrib & uídos & & Nulo & Fraca & NEUTRO & Indifere & *N2* & & 0 \\
\hline Ruim/in & & & & & Nulo & Negativo & Ruim/in & N1 & & -21 \\
\hline & & & & & & Posição da & Mediana: & & N3 & 51 \\
\hline
\end{tabular}

\begin{tabular}{|c|c|c|c|c|c|c|c|c|c|c|}
\hline \multirow{2}{*}{$\begin{array}{c}\text { Obj. Estudo } \\
\underline{0}\end{array}$} & \multicolumn{5}{|c|}{ 4.1.3 Privacidade } & \multirow{2}{*}{$\begin{array}{l}\text { Opções } \\
\text { Mediana }\end{array}$} & \multirow{2}{*}{$\begin{array}{l}\text { Opções } \\
\text { Modelo }\end{array}$} & \multirow{2}{*}{$\begin{array}{r}\text { Nível } \\
\text { Impact }\end{array}$} & \multirow{2}{*}{$\begin{array}{l}\text { Marque } \\
\text { Com->x }\end{array}$} & \multirow[t]{2}{*}{ Escala } \\
\hline & Excel & M Bom & Bom & Indifere & Ruim/in & & & & & \\
\hline Excel & Nulo & Forte & M for/Fort & M uitoForte & Extr/M fort & Ótimo & Excel & N5 & & 149 \\
\hline M Bom & & Nulo & Forte & M for/Fort & Extr/M fort & $\mathrm{BOM}$ & MBom & $* N 4 *$ & & 100 \\
\hline Bom & Esfor & ç०S & Nulo & M for/Fort & M uito Forte & Regular & Bom & N3 & $x$ & 54 \\
\hline Indifere & Atrib & uídos & & Nulo & Forte & NEUTRO & Indifere & *N2* & & 0 \\
\hline Ruim/in & & & & & Nulo & Negativo & Ruim/in & N1 & & -40 \\
\hline & & & & & & \multicolumn{3}{|c|}{ Posição da Mediana: } & N3 & 54 \\
\hline
\end{tabular}

\begin{tabular}{|c|c|c|c|c|c|c|c|c|c|c|}
\hline \multirow{2}{*}{$\begin{array}{c}\text { Obj. Estudo } \\
\underline{0}\end{array}$} & \multicolumn{5}{|c|}{ 4.1.4 Confiabilidade - Disponiblidade do serviço } & \multirow{2}{*}{$\begin{array}{l}\text { Opções } \\
\text { Mediana }\end{array}$} & \multirow{2}{*}{$\begin{array}{l}\text { Opções } \\
\text { Modelo }\end{array}$} & \multirow{2}{*}{$\begin{array}{l}\text { Nível } \\
\text { Impact }\end{array}$} & \multirow{2}{*}{$\begin{array}{l}\text { Marque } \\
\text { Com->x }\end{array}$} & \multirow[t]{2}{*}{ Escala } \\
\hline & Excel & M B om & Bom & Indifere & Ruim/in & & & & & \\
\hline Excel & Nulo & M for/Fort & M uitoForte & Extr/M fort & Extremo & Ótimo & Excel & N5 & & 190 \\
\hline M Bom & & Nulo & M for/Fort & M uitoForte & Extr/M fort & BOM & MBom & *N4* & & 100 \\
\hline Bom & Esfor & ç०S & Nulo & MuitoFraca & Frac/M frac & Regular & Bom & N3 & $x$ & 30 \\
\hline Indifere & Atrib & uídos & & Nulo & M uito F raca & NEUTRO & Indifere & *N2* & & 0 \\
\hline Ruim/in & & & & & Nulo & Negativo & Ruim/in & N1 & & -83 \\
\hline & & & & & & Posição da & Mediana & & N3 & 30 \\
\hline
\end{tabular}

\begin{tabular}{|c|c|c|c|c|c|c|c|c|c|c|}
\hline \multirow{2}{*}{$\begin{array}{c}\text { Obj. Estudo } \\
\underline{0} \\
\end{array}$} & \multicolumn{5}{|c|}{ 4.2.1 Serviço de Pós-venda - Atendimento } & \multirow{2}{*}{\begin{tabular}{|c|} 
Opções \\
Mediana \\
\end{tabular}} & \multirow{2}{*}{$\begin{array}{l}\text { Opções } \\
\text { Modelo }\end{array}$} & \multirow{2}{*}{$\begin{array}{r}\text { Nível } \\
\text { Impact }\end{array}$} & \multirow{2}{*}{$\begin{array}{l}\text { Marque } \\
\text { Com->x }\end{array}$} & \multirow[t]{2}{*}{ Escala } \\
\hline & Excel & M Bom & Bom & Indifere & Ruim/in & & & & & \\
\hline Excel & Nulo & Fort/M ode & M for/Fort & M uito Forte & Extr/M fort & Ótimo & Excel & N5 & & 153 \\
\hline M B om & & Nulo & Fort/M o de & Forte & M for/Fort & BOM & MBom & *N4* & & 100 \\
\hline Bom & Esfor & $c ̧ \circ S$ & Nulo & M ode/Frac & M oderado & Regular & Bom & N3 & & 40 \\
\hline Indifere & Atrib & uíd os & & Nulo & M ode/Frac & NEUTRO & Indifere & *N2* & & 0 \\
\hline Ruim/in & & & & & Nulo & Negativo & Ruim/in & N1 & $\mathrm{x}$ & -47 \\
\hline & & & & & & Posição d & Mediana & & N1 & -47 \\
\hline
\end{tabular}




\begin{tabular}{|c|c|c|c|c|c|c|c|c|c|c|}
\hline \multirow{2}{*}{$\begin{array}{c}\text { Obj. Estudo } \\
\underline{0} \\
\end{array}$} & \multicolumn{5}{|c|}{ 4.2.2 Atendimento para reclamações } & \multirow{2}{*}{$\begin{array}{c}\text { Opções } \\
\text { Mediana }\end{array}$} & \multirow{2}{*}{$\begin{array}{l}\text { Opções } \\
\text { Modelo }\end{array}$} & \multirow{2}{*}{$\begin{array}{r}\text { Nível } \\
\text { Impact }\end{array}$} & \multirow{2}{*}{$\begin{array}{c}\text { Marque } \\
\text { Com->x }\end{array}$} & \multirow[t]{2}{*}{ Escala } \\
\hline & Excel & M Bom & Bom & Indifere & Ruim/in & & & & & \\
\hline Excel & Nulo & M for/Fort & M uitoForte & Extr/M fort & Extremo & Ótimo & Excel & N5 & & 179 \\
\hline M Bom & & Nulo & Forte & M uitoForte & Extr/M fort & $\mathrm{BOM}$ & MBom & *N4* & & 100 \\
\hline Bom & Esfor & çOS & Nulo & Fraca & Mode/Frac & Regular & Bom & N3 & & 37 \\
\hline Indifere & Atrib & uíd os & & Nulo & Frac/M frac & NEUTRO & Indifere & $* \mathrm{~N} 2 *$ & & 0 \\
\hline Ruim/in & & & & & Nulo & Negativo & Ruim/in & N1 & $x$ & -67 \\
\hline & & & & & & \multicolumn{3}{|c|}{ Posição da Mediana: } & N1 & -67 \\
\hline
\end{tabular}


APÊNDICE G - MATRIZES SEMÂNTICAS E POSIÇÃO DA MEDIANA (UBER)

UBER

\begin{tabular}{|c|c|c|c|c|c|c|c|c|c|c|}
\hline \multirow{2}{*}{$\begin{array}{c}\text { Obj. Estudo } \\
\underline{0}\end{array}$} & \multicolumn{5}{|c|}{ 1.1.1 Dirigibilidade / Condução do Veículo } & \multirow{2}{*}{$\begin{array}{c}\text { Opções } \\
\text { Mediana }\end{array}$} & \multirow{2}{*}{$\begin{array}{l}\text { Opções } \\
\text { Modelo }\end{array}$} & \multirow{2}{*}{$\begin{array}{r}\text { Nível } \\
\text { Impact }\end{array}$} & \multirow{2}{*}{$\begin{array}{l}\text { Marque } \\
\text { Com->x }\end{array}$} & \multirow[t]{2}{*}{ Escala } \\
\hline & Excel & M Bom & Bom & Indifere & Ruim/in & & & & & \\
\hline Excel & Nulo & Forte & M for/Fort & MuitoForte & Extr/M fort & Ótimo & Excel & N5 & & 155 \\
\hline M Bom & & Nulo & Fort/M ode & Forte & M for/Fort & BOM & MBom & *N4* & $x$ & 100 \\
\hline Bom & Esfor & Ç O S & Nulo & M oderado & Fort/M ode & Regular & Bom & N3 & & 47 \\
\hline Indifere & Atrib & uídos & & Nulo & Mode/Frac & NEUTRO & Indifere & *N2* & & 0 \\
\hline Ruim/in & & & & & Nulo & Negativo & Ruim/in & N1 & & -41 \\
\hline & & & & & & Posição da & Mediana & & *N4* & 100 \\
\hline
\end{tabular}

\begin{tabular}{|c|c|c|c|c|c|c|c|c|c|c|}
\hline \multirow{2}{*}{$\begin{array}{c}\text { Obj. Estudo } \\
\underline{0}\end{array}$} & \multicolumn{5}{|c|}{ 1.1.2 Gentileza e Empatia no trato verbal } & \multirow{2}{*}{$\begin{array}{c}\text { Opções } \\
\text { Mediana }\end{array}$} & \multirow{2}{*}{$\begin{array}{l}\text { Opções } \\
\text { Modelo }\end{array}$} & \multirow{2}{*}{$\begin{array}{r}\text { Nível } \\
\text { Impact }\end{array}$} & \multirow{2}{*}{$\begin{array}{l}\text { Marque } \\
\text { Com->X }\end{array}$} & \multirow[t]{2}{*}{ Escala } \\
\hline & Excel & M Bom & Bom & Indifere & Ruim/in & & & & & \\
\hline Excel & Nulo & M for/Fort & M uitoForte & Extr/M fort & Extremo & Ótimo & Excel & N5 & $x$ & 189 \\
\hline M Bom & & Nulo & M uito Forte & Extr/M fort & Extremo & $\mathrm{BOM}$ & MBom & *N4* & & 100 \\
\hline Bom & Es for & ç O S & Nulo & MuitoFraca & Fraca & Regular & Bom & N3 & & 31 \\
\hline Indifere & Atrib & uíd os & & Nulo & M uito F raca & NEUTRO & Indifere & *N2* & & 0 \\
\hline Ruim/in & & & & & Nulo & Negativo & Ruim/in & N1 & & -88 \\
\hline & & & & & & Posição da & Mediana & & N5 & 189 \\
\hline
\end{tabular}

\begin{tabular}{|c|c|c|c|c|c|c|c|c|c|c|}
\hline \multirow{2}{*}{$\begin{array}{c}\text { Obj. Estudo } \\
\underline{0}\end{array}$} & \multicolumn{5}{|c|}{ 1.1.3 Prestatividade para ações físicas } & \multirow{2}{*}{$\begin{array}{c}\text { Opções } \\
\text { Mediana } \\
\end{array}$} & \multirow{2}{*}{$\begin{array}{l}\text { Opções } \\
\text { Modelo }\end{array}$} & \multirow{2}{*}{$\begin{array}{r}\text { Nível } \\
\text { Impact }\end{array}$} & \multirow{2}{*}{$\begin{array}{l}\text { Marque } \\
\text { Com->x }\end{array}$} & \multirow[t]{2}{*}{ Escala } \\
\hline & Excel & M Bom & Bom & Indifere & Ruim/in & & & & & \\
\hline Excel & Nulo & Fraca & Mode/Frac & Moderado & Fort/M ode & Ótimo & Excel & N5 & & 118 \\
\hline M Bom & & Nulo & Fraca & Mode/Frac & Moderado & BOM & MBom & $* N 4 *$ & $x$ & 100 \\
\hline Bom & Es for & ç O S & Nulo & Fraca & Moderado & Regular & Bom & N3 & & 55 \\
\hline Indifere & Atrib & uíd os & & Nulo & Frac/M frac & NEUTRO & Indifere & *N2* & & 0 \\
\hline Ruim/in & & & & & Nulo & Negativo & Ruim/in & N1 & & -12 \\
\hline & & & & & & \multicolumn{3}{|c|}{ Posição da Mediana: } & $* N 4 *$ & 100 \\
\hline
\end{tabular}

\begin{tabular}{|c|c|c|c|c|c|c|c|c|c|c|}
\hline \multirow{2}{*}{$\begin{array}{c}\text { Obj. Estudo } \\
\underline{0}\end{array}$} & \multicolumn{5}{|c|}{ 1.1.4 Higiene Pessoal } & \multirow{2}{*}{$\begin{array}{c}\text { Opções } \\
\text { Mediana }\end{array}$} & \multirow{2}{*}{$\begin{array}{l}\text { Opções } \\
\text { Modelo }\end{array}$} & \multirow{2}{*}{$\begin{array}{r}\text { Nível } \\
\text { Impact }\end{array}$} & \multirow{2}{*}{$\begin{array}{l}\text { Marque } \\
\text { Com->X }\end{array}$} & \multirow[t]{2}{*}{ Escala } \\
\hline & Excel & M Bom & Bom & Indifere & Ruim/in & & & & & \\
\hline Excel & Nulo & Mode/Frac & Fort/M ode & Forte & M for/Fort & Ótimo & Excel & N5 & $x$ & 133 \\
\hline M Bom & & Nulo & Fraca & M o derado & Fort/M ode & $\mathrm{BOM}$ & MBom & *N4* & & 100 \\
\hline Bom & Esfor & ç०S & Nulo & Mode/Frac & M o derado & Regular & Bom & N3 & & 55 \\
\hline Indifere & Atrib & uídos & & Nulo & Fraca & NEUTRO & Indifere & *N2* & & 0 \\
\hline Ruim/in & & & & & Nulo & Negativo & Ruim/in & N1 & & -21 \\
\hline & & & & & & \multicolumn{3}{|c|}{ Posição da Mediana: } & N5 & 133 \\
\hline
\end{tabular}

\begin{tabular}{|c|c|c|c|c|c|c|c|c|c|c|}
\hline \multirow{2}{*}{$\begin{array}{c}\text { Obj. Estudo } \\
\underline{0}\end{array}$} & \multicolumn{5}{|c|}{ 1.1.5 Acesso à segunda língua } & \multirow{2}{*}{$\begin{array}{c}\text { Opções } \\
\text { Mediana }\end{array}$} & \multirow{2}{*}{$\begin{array}{l}\text { Opções } \\
\text { Modelo }\end{array}$} & \multirow{2}{*}{$\begin{array}{r}\text { Nível } \\
\text { Impact }\end{array}$} & \multirow{2}{*}{$\begin{array}{l}\text { Marque } \\
\text { Com->x }\end{array}$} & \multirow[t]{2}{*}{ Escala } \\
\hline & Excel & M Bom & Bom & Indifere & Ruim/in & & & & & \\
\hline Excel & Nulo & M for/Fort & M uito Forte & Extr/M fort & Extremo & Ótimo & Excel & N5 & & 166 \\
\hline M Bom & & Nulo & M uito Forte & Extr/M fort & Extremo & BOM & MBom & *N4* & & 100 \\
\hline Bom & Es for & ç O s & Nulo & Mo derado & Fort/M ode & Regular & Bom & N3 & & 38 \\
\hline Indifere & Atrib & uídos & & Nulo & Mode/Frac & NEUTRO & Indifere & *N2* & $x$ & 0 \\
\hline Ruim/in & & & & & Nulo & Negativo & Ruim/in & N1 & & -68 \\
\hline & & & & & & \multicolumn{3}{|c|}{ Posição da Mediana: } & $* \mathrm{~N} 2 *$ & 0 \\
\hline
\end{tabular}




\begin{tabular}{|c|c|c|c|c|c|c|c|c|c|c|}
\hline \multirow{2}{*}{$\begin{array}{c}\text { Obj. Estudo } \\
\underline{0} \\
\end{array}$} & \multicolumn{5}{|c|}{ 1.2.1 Sugestão de Trajetos Possíveis } & \multirow{2}{*}{$\begin{array}{c}\text { Opções } \\
\text { Mediana }\end{array}$} & \multirow{2}{*}{$\begin{array}{l}\text { Opções } \\
\text { Modelo }\end{array}$} & \multirow{2}{*}{\begin{tabular}{|r|}
$\begin{array}{r}\text { Nível } \\
\text { Impact }\end{array}$ \\
\end{tabular}} & \multirow{2}{*}{$\begin{array}{l}\text { Marque } \\
\text { Com->x }\end{array}$} & \multirow[t]{2}{*}{ Escala } \\
\hline & Excel & M Bom & Bom & Indifere & Ruim/in & & & & & \\
\hline Excel & Nulo & Fort/M ode & Forte & M for/Fort & M uito Forte & Ótimo & Excel & N5 & & 143 \\
\hline M Bom & & Nulo & M o derado & Fort/M ode & M for/Fort & BOM & MBom & $* N 4 *$ & $x$ & 100 \\
\hline Bom & Esfor & ços & Nulo & Mo oderado & Fort/M ode & Regular & Bom & N3 & & 50 \\
\hline Indifere & Atrib & uíd os & & Nulo & M ode/Frac & NEUTRO & Indifere & *N2* & & 0 \\
\hline Ruim/in & & & & & Nulo & Negativo & Ruim/in & N1 & & -32 \\
\hline & & & & & & Posição d & Mediana & & $* N 4 *$ & 100 \\
\hline
\end{tabular}

\begin{tabular}{|c|c|c|c|c|c|c|c|c|c|c|}
\hline \multirow{2}{*}{$\begin{array}{c}\text { Obj. Estudo } \\
\underline{0}\end{array}$} & \multicolumn{5}{|c|}{ 1.2.2 Proatividade para solucionar prob tráfego } & \multirow{2}{*}{$\begin{array}{c}\text { Opções } \\
\text { Mediana }\end{array}$} & \multirow{2}{*}{$\begin{array}{l}\text { Opções } \\
\text { Modelo }\end{array}$} & \multirow{2}{*}{\begin{tabular}{|} 
Nível \\
Impact
\end{tabular}} & \multirow{2}{*}{$\begin{array}{l}\text { Marque } \\
\text { Com->x }\end{array}$} & \multirow[t]{2}{*}{ Escala } \\
\hline & Excel & M Bom & Bom & Indifere & Ruim/in & & & & & \\
\hline Excel & Nulo & M for/Fort & M uito Forte & Extr/M fort & Extremo & Ótimo & Excel & N5 & & 189 \\
\hline M Bom & & Nulo & Forte & M for/Fort & M uito Forte & $\mathrm{BOM}$ & MBom & *N4* & $x$ & 100 \\
\hline Bom & Es f or & ços & Nulo & MuitoFraca & Frac/M frac & Regular & Bom & N3 & & 30 \\
\hline Indifere & Atrib & uídos & & Nulo & Frac/M frac & NEUTRO & Indifere & $* N 2 *$ & & 0 \\
\hline Ruim/in & & & & & Nulo & Negativo & Ruim/in & $\mathrm{N} 1$ & & -76 \\
\hline & & & & & & Posição d & Mediana: & & $* N 4 *$ & 100 \\
\hline
\end{tabular}

\begin{tabular}{|c|c|c|c|c|c|c|c|c|c|c|}
\hline \multirow{2}{*}{$\begin{array}{c}\text { Obj. Estudo } \\
\underline{0} \\
\end{array}$} & \multicolumn{5}{|c|}{ 1.2.3 Pontualidade para chegar ao destino } & \multirow{2}{*}{$\begin{array}{c}\text { Opções } \\
\text { Mediana }\end{array}$} & \multirow{2}{*}{$\begin{array}{l}\text { Opções } \\
\text { Modelo }\end{array}$} & \multirow{2}{*}{$\begin{array}{r}\text { Nível } \\
\text { Impact }\end{array}$} & \multirow{2}{*}{$\begin{array}{l}\text { Marque } \\
\text { Com->x }\end{array}$} & \multirow[t]{2}{*}{ Escala } \\
\hline & Excel & M Bom & Bom & Indifere & Ruim/in & & & & & \\
\hline Excel & Nulo & M for/Fort & M uito Forte & Extr/M fort & Extremo & Ótimo & Excel & N5 & & 165 \\
\hline M Bom & & Nulo & M for/Fort & M uitoForte & Extr/M fort & BOM & MBom & ${ }^{*} \mathrm{~N} 4 *$ & $x$ & 100 \\
\hline Bom & Esfor & ç Os & Nulo & Fort/M ode & Forte & Regular & Bom & N3 & & 45 \\
\hline Indifere & Atrib & uídos & & Nulo & Fraca & \begin{tabular}{|l|} 
NEUTRO \\
\end{tabular} & Indifere & $* \mathrm{~N} 2 *$ & & 0 \\
\hline Ruim/in & & & & & Nulo & Negativo & Ruim/in & N1 & & -55 \\
\hline & & & & & & \multicolumn{3}{|c|}{ Posição da Mediana: } & $* N 4 *$ & 100 \\
\hline
\end{tabular}

\begin{tabular}{|c|c|c|c|c|c|c|c|c|c|c|}
\hline \multirow{2}{*}{$\begin{array}{c}\text { Obj. Estudo } \\
\underline{0} \\
\end{array}$} & \multicolumn{5}{|c|}{ 1.3.1 Espaço Interno Adequado } & \multirow{2}{*}{$\begin{array}{c}\text { Opções } \\
\text { Mediana } \\
\end{array}$} & \multirow{2}{*}{$\begin{array}{l}\text { Opções } \\
\text { Modelo }\end{array}$} & \multirow{2}{*}{$\begin{array}{r}\text { Nível } \\
\text { Impact } \\
\end{array}$} & \multirow{2}{*}{$\begin{array}{l}\text { Marque } \\
\text { Com->x }\end{array}$} & \multirow[t]{2}{*}{ Escala } \\
\hline & Excel & M Bom & Bom & Indifere & Ruim/in & & & & & \\
\hline Excel & Nulo & M for/Fort & M uito Forte & Extr/M fort & Extremo & Ótimo & Excel & N5 & $x$ & 177 \\
\hline M Bom & & Nulo & M uitoForte & Extr/M fort & Extremo & BOM & MBom & $* N 4 *$ & & 100 \\
\hline Bom & Es f or & ç०S & Nulo & Fraca & Mode/Frac & Regular & Bom & N3 & & 33 \\
\hline Indifere & Atrib & uíd os & & Nulo & Fraca & NEUTRO & Indifere & *N2* & & 0 \\
\hline Ruim/in & & & & & Nulo & Negativo & Ruim/in & N1 & & -79 \\
\hline & & & & & & Posição d & Mediana & & N5 & 177 \\
\hline
\end{tabular}

\begin{tabular}{|c|c|c|c|c|c|c|c|c|c|c|}
\hline \multirow{2}{*}{$\begin{array}{c}\text { Obj. Estudo } \\
\underline{0}\end{array}$} & \multicolumn{5}{|c|}{ 1.3.2 Ambiente agradável } & \multirow{2}{*}{$\begin{array}{c}\text { Opções } \\
\text { Mediana }\end{array}$} & \multirow{2}{*}{$\begin{array}{c}\text { Opções } \\
\text { Modelo }\end{array}$} & \multirow{2}{*}{$\begin{array}{r}\text { Nível } \\
\text { Impact }\end{array}$} & \multirow{2}{*}{$\begin{array}{l}\text { Marque } \\
\text { Com->x }\end{array}$} & \multirow[t]{2}{*}{ Escala } \\
\hline & Excel & M Bom & Bom & Indifere & Ruim/in & & & & & \\
\hline Excel & Nulo & Moderado & Fort/M ode & Forte & M uito Forte & Ótimo & Excel & N5 & $x$ & 132 \\
\hline M Bom & & Nulo & Fort/M ode & Forte & M for/Fort & BOM & MBom & *N4* & & 100 \\
\hline Bom & Esfor & çOS & Nulo & Mo oderado & Fort/M ode & Regular & Bom & N3 & & 48 \\
\hline Indifere & Atrib & uídos & & Nulo & Fraca & NEUTRO & Indifere & *N2* & & 0 \\
\hline Ruim/in & & & & & Nulo & Negativo & Ruim/in & N1 & & -33 \\
\hline & & & & & & Posição d & Mediana: & & N5 & 132 \\
\hline
\end{tabular}




\begin{tabular}{|c|c|c|c|c|c|c|c|c|c|c|}
\hline \multirow{2}{*}{$\begin{array}{c}\text { Obj. Estudo } \\
\underline{0}\end{array}$} & \multicolumn{5}{|c|}{$\underline{\underline{1} 3.3 \text { Limpeza e conservação }}$} & \multirow{2}{*}{$\begin{array}{l}\text { Opções } \\
\text { Mediana }\end{array}$} & \multirow{2}{*}{$\begin{array}{l}\text { Opções } \\
\text { Modelo }\end{array}$} & \multirow{2}{*}{$\begin{array}{l}\text { Nível } \\
\text { Impact }\end{array}$} & \multirow{2}{*}{$\begin{array}{l}\text { Marque } \\
\text { Com->x }\end{array}$} & \multirow[t]{2}{*}{ Escala } \\
\hline & Excel & M Bom & Bom & Indifere & Ruim/in & & & & & \\
\hline Excel & Nulo & Fraca & Mode/Frac & Mo oderado & Forte & Ótimo & Excel & N5 & $x$ & 121 \\
\hline M Bom & & Nulo & Fraca & Mode/Frac & Moderado & $\mathrm{BOM}$ & MBom & $* N 4 *$ & & 100 \\
\hline Bom & Esfor & ç OS & Nulo & Fraca & Mode/Frac & Regular & Bom & N3 & & 52 \\
\hline Indifere & Atrib & uíd os & & Nulo & Frac/M frac & NEUTRO & Indifere & ${ }^{*} \mathrm{~N} 2 *$ & & 0 \\
\hline Ruim/in & & & & & Nulo & Negativo & Ruim/in & N1 & & -15 \\
\hline & & & & & & Posição da & Mediana & & N5 & 121 \\
\hline
\end{tabular}

\begin{tabular}{|c|c|c|c|c|c|c|c|c|c|c|}
\hline \multirow{2}{*}{$\begin{array}{c}\text { Obj. Estudo } \\
\underline{0}\end{array}$} & \multicolumn{5}{|c|}{ 1.3.4 Serviços de bordo adicionais } & \multirow{2}{*}{$\begin{array}{c}\text { Opções } \\
\text { Mediana }\end{array}$} & \multirow{2}{*}{$\begin{array}{l}\text { Opções } \\
\text { Modelo }\end{array}$} & \multirow{2}{*}{$\begin{array}{r}\text { Nível } \\
\text { Impact }\end{array}$} & \multirow{2}{*}{$\begin{array}{l}\text { Marque } \\
\text { Com->x }\end{array}$} & \multirow[t]{2}{*}{ Escala } \\
\hline & Excel & M Bom & Bom & Indifere & Ruim/in & & & & & \\
\hline Excel & Nulo & Frac/M frac & Fraca & M ode/Frac & M oderado & Ótimo & Excel & N5 & & 115 \\
\hline M Bom & & Nulo & $\mathrm{Frac} / \mathrm{M}$ frac & Fraca & Mode/Frac & $\mathrm{BOM}$ & MBom & *N4* & $x$ & 100 \\
\hline Bom & Esfor & ç O S & Nulo & Frac/M frac & Fraca & Regular & Bom & N3 & & 48 \\
\hline Indifere & Atrib & uíd os & & Nulo & Fraca & NEUTRO & Indifere & $* \mathrm{~N} 2 *$ & & 0 \\
\hline Ruim/in & & & & & Nulo & Negativo & Ruim/in & N1 & & -11 \\
\hline & & & & & & Posição da & Mediana & & ${ }^{*} \mathrm{~N} 4 *$ & 100 \\
\hline
\end{tabular}

\begin{tabular}{|c|c|c|c|c|c|c|c|c|c|c|}
\hline \multirow{2}{*}{$\begin{array}{c}\text { Obj. Estudo } \\
\underline{0}\end{array}$} & \multicolumn{5}{|c|}{ 1.3.5 Espaço do porta-malas } & \multirow{2}{*}{$\begin{array}{c}\text { Opções } \\
\text { Mediana }\end{array}$} & \multirow{2}{*}{$\begin{array}{l}\text { Opções } \\
\text { Modelo }\end{array}$} & \multirow{2}{*}{$\begin{array}{l}\text { Nível } \\
\text { Impact }\end{array}$} & \multirow{2}{*}{$\begin{array}{l}\text { Marque } \\
\text { Com->x }\end{array}$} & \multirow[t]{2}{*}{ Escala } \\
\hline & Excel & M Bom & Bom & Indifere & Ruim/in & & & & & \\
\hline Excel & Nulo & M for/Fort & M uitoForte & Extr/M fort & Extremo & Ótimo & Excel & N5 & & 158 \\
\hline M Bom & & Nulo & M for/Fort & M uitoForte & Extr/M fort & BOM & MBom & $* N 4 *$ & $x$ & 100 \\
\hline Bom & Esfor & ç O S & Nulo & Forte & M for/Fort & Regular & Bom & N3 & & 47 \\
\hline Indifere & Atrib & uíd os & & Nulo & Fort/M ode & NEUTRO & Indifere & $* \mathrm{~N} 2 *$ & & 0 \\
\hline Ruim/in & & & & & Nulo & Negativo & Ruim/in & N1 & & -52 \\
\hline & & & & & & \multicolumn{3}{|c|}{ Posição da Mediana: } & *N4* & 100 \\
\hline
\end{tabular}

\begin{tabular}{|c|c|c|c|c|c|c|c|c|c|c|}
\hline \multirow{2}{*}{$\begin{array}{c}\text { Obj. Estudo } \\
\underline{0}\end{array}$} & \multicolumn{5}{|c|}{ 2.1.1 Preço do Serviço } & \multirow{2}{*}{$\begin{array}{l}\text { Opções } \\
\text { Mediana }\end{array}$} & \multirow{2}{*}{$\begin{array}{l}\text { Opções } \\
\text { Modelo }\end{array}$} & \multirow{2}{*}{$\begin{array}{r}\text { Nível } \\
\text { Impact }\end{array}$} & \multirow{2}{*}{$\begin{array}{l}\text { Marque } \\
\text { Com->x }\end{array}$} & \multirow[t]{2}{*}{ Escala } \\
\hline & Excel & M Bom & Bom & Indifere & Ruim/in & & & & & \\
\hline Excel & Nulo & M for/Fort & M uito Forte & Extr/M fort & Extremo & Ótimo & Excel & N5 & & 185 \\
\hline M B om & & Nulo & M uito Forte & Extr/M fort & Extremo & $\mathrm{BOM}$ & MBom & ${ }^{*} \mathrm{~N} 4 *$ & $x$ & 100 \\
\hline Bom & Esfor & ç O S & Nulo & Frac/M frac & Fraca & Regular & Bom & N3 & & 32 \\
\hline Indifere & Atrib & uídos & & Nulo & M uitoFraca & NEUTRO & Indifere & *N2* & & 0 \\
\hline Ruim/in & & & & & Nulo & Negativo & Ruim/in & N1 & & -84 \\
\hline & & & & & & Posição d & Mediana & & $* N 4 *$ & 100 \\
\hline
\end{tabular}

\begin{tabular}{|c|c|c|c|c|c|c|c|c|c|c|}
\hline \multirow{2}{*}{$\begin{array}{c}\text { Obj. Estudo } \\
\underline{0}\end{array}$} & \multicolumn{5}{|c|}{ 2.1.2 Facilidade (formas) de pagamento } & \multirow{2}{*}{$\begin{array}{c}\text { Opções } \\
\text { Mediana } \\
\end{array}$} & \multirow{2}{*}{$\begin{array}{l}\text { Opções } \\
\text { Modelo }\end{array}$} & \multirow{2}{*}{$\begin{array}{r}\text { Nível } \\
\text { Impact }\end{array}$} & \multirow{2}{*}{$\begin{array}{l}\text { Marque } \\
\text { Com->X }\end{array}$} & \multirow[t]{2}{*}{ Escala } \\
\hline & Excel & M Bom & Bom & Indifere & Ruim/in & & & & & \\
\hline Excel & Nulo & Fort/M ode & Forte & M for/Fort & Extr/M fort & Ótimo & Excel & N5 & $x$ & 146 \\
\hline M B om & & Nulo & Fort/M ode & Forte & M for/Fort & BOM & MBom & $* N 4 *$ & & 100 \\
\hline Bom & Es for & ços & Nulo & Moderado & Forte & Regular & Bom & N3 & & 50 \\
\hline Indifere & Atrib & uídos & & \begin{tabular}{|l} 
Nulo \\
\end{tabular} & Fraca & NEUTRO & Indifere & *N2* & & 0 \\
\hline Ruim/in & & & & & Nulo & Negativo & Ruim/in & N1 & & -36 \\
\hline & & & & & & \multicolumn{3}{|c|}{ Posição da Mediana: } & N5 & 146 \\
\hline
\end{tabular}




\begin{tabular}{|c|c|c|c|c|c|c|c|c|c|c|}
\hline \multirow{2}{*}{$\begin{array}{c}\text { Obj. Estudo } \\
\underline{0}\end{array}$} & \multicolumn{5}{|c|}{ 2.1.3 Controle do valor a ser pago na corrida } & \multirow{2}{*}{$\begin{array}{l}\text { Opções } \\
\text { Mediana }\end{array}$} & \multirow{2}{*}{$\begin{array}{l}\text { Opções } \\
\text { Modelo }\end{array}$} & \multirow{2}{*}{$\begin{array}{l}\text { Nível } \\
\text { Impact }\end{array}$} & \multirow{2}{*}{$\begin{array}{l}\text { Marque } \\
\text { Com->x }\end{array}$} & \multirow[t]{2}{*}{ Escala } \\
\hline & Excel & M Bom & Bom & Indifere & Ruim/in & & & & & \\
\hline Excel & Nulo & Mode/Frac & M oderado & Fort/M ode & Forte & Ótimo & Excel & N5 & & 127 \\
\hline M Bom & & Nulo & Fraca & Mode/Frac & Moderado & $\mathrm{BOM}$ & MBom & $* N 4 *$ & $x$ & 100 \\
\hline Bom & Es for & ç Os & Nulo & Mode/Frac & Moderado & Regular & Bom & N3 & & 58 \\
\hline Indifere & Atrib & uíd os & & Nulo & Fraca & NEUTRO & Indifere & *N2* & & 0 \\
\hline Ruim/in & & & & & Nulo & Negativo & Ruim/in & N1 & & -14 \\
\hline & & & & & & Posição da & Mediana & & *N4* & 100 \\
\hline
\end{tabular}

\begin{tabular}{|c|c|c|c|c|c|c|c|c|c|c|}
\hline \multirow{2}{*}{$\begin{array}{c}\text { Obj. Estudo } \\
\underline{0}\end{array}$} & \multicolumn{5}{|c|}{ 2.1.4 Tranparência da fórmula de cálculo da tarifa } & \multirow{2}{*}{$\begin{array}{l}\text { Opções } \\
\text { Mediana }\end{array}$} & \multirow{2}{*}{$\begin{array}{l}\text { Opções } \\
\text { Modelo }\end{array}$} & \multirow{2}{*}{$\begin{array}{l}\text { Nível } \\
\text { Impact }\end{array}$} & \multirow{2}{*}{$\begin{array}{l}\text { Marque } \\
\text { Com->x }\end{array}$} & \multirow[t]{2}{*}{ Escala } \\
\hline & Excel & M Bom & Bom & Indifere & Ruim/in & & & & & \\
\hline Excel & Nulo & M for/Fort & M uito Forte & Extr/M fort & Extremo & Ótimo & Excel & N5 & & 166 \\
\hline M Bom & & Nulo & M for/Fort & M uitoForte & Extr/M fort & $\mathrm{BOM}$ & MBom & $* N 4 *$ & $x$ & 100 \\
\hline Bom & Es f or & ç O S & Nulo & Mo oderado & Fort/Mode & Regular & Bom & N3 & & 39 \\
\hline Indifere & Atrib & uíd os & & Nulo & M o derado & NEUTRO & Indifere & *N2* & & 0 \\
\hline Ruim/in & & & & & Nulo & Negativo & Ruim/in & N1 & & -61 \\
\hline & & & & & & Posição da & Mediana & & *N4* & 100 \\
\hline
\end{tabular}

\begin{tabular}{|c|c|c|c|c|c|c|c|c|c|c|}
\hline \multirow{2}{*}{$\begin{array}{c}\text { Obj. Estudo } \\
\underline{0}\end{array}$} & \multicolumn{5}{|c|}{$\underline{2.2 .1}$ Imagem da Marca - UBER } & \multirow{2}{*}{$\begin{array}{l}\text { Opções } \\
\text { Mediana }\end{array}$} & \multirow{2}{*}{$\begin{array}{l}\text { Opções } \\
\text { Modelo }\end{array}$} & \multirow{2}{*}{$\begin{array}{r}\text { Nível } \\
\text { Impact }\end{array}$} & \multirow{2}{*}{$\begin{array}{l}\text { Marque } \\
\text { Com->x }\end{array}$} & \multirow[t]{2}{*}{ Escala } \\
\hline & Excel & M Bom & Bom & Indifere & Ruim/in & & & & & \\
\hline Excel & Nulo & M for/Fort & M uito Forte & Extr/M fort & Extremo & Ótimo & Excel & N5 & & 191 \\
\hline M Bom & & Nulo & M uito Forte & Extr/M fort & Extremo & $\mathrm{BOM}$ & MBom & *N4* & $x$ & 100 \\
\hline Bom & Esfor & ç O S & Nulo & MuitoFraca & Frac/M frac & Regular & Bom & N3 & & 30 \\
\hline Indifere & Atrib & uíd os & & Nulo & M uitoFraca & NEUTRO & Indifere & *N2* & & 0 \\
\hline Ruim/in & & & & & Nulo & Negativo & Ruim/in & N1 & & -91 \\
\hline & & & & & & Posição da & Mediana & & *N4* & 100 \\
\hline
\end{tabular}

\begin{tabular}{|c|c|c|c|c|c|c|c|c|c|c|}
\hline \multirow{2}{*}{$\begin{array}{c}\text { Obj. Estudo } \\
\underline{0}\end{array}$} & \multicolumn{5}{|c|}{$\underline{\text { 2.2.2 }}$ Percepção de valor do serviço } & \multirow{2}{*}{$\begin{array}{l}\text { Opções } \\
\text { Mediana }\end{array}$} & \multirow{2}{*}{$\begin{array}{l}\text { Opções } \\
\text { Modelo }\end{array}$} & \multirow{2}{*}{$\begin{array}{l}\text { Nível } \\
\text { Impact }\end{array}$} & \multirow{2}{*}{$\begin{array}{l}\text { Marque } \\
\text { Com->x }\end{array}$} & \multirow[t]{2}{*}{ Escala } \\
\hline & Excel & M Bom & Bom & Indifere & Ruim/in & & & & & \\
\hline Excel & Nulo & M for/Fort & M uito Forte & Extr/M fort & Extremo & Ótimo & Excel & N5 & & 178 \\
\hline M Bom & & Nulo & Forte & M for/Fort & M uito Forte & BOM & MBom & *N4* & $x$ & 100 \\
\hline Bom & Es for & ç O S & Nulo & Fraca & Moderado & Regular & Bom & N3 & & 38 \\
\hline Indifere & Atrib & uíd os & & Nulo & Frac/M frac & NEUTRO & Indifere & ${ }^{*} \mathrm{~N} 2 *$ & & 0 \\
\hline Ruim/in & & & & & Nulo & Negativo & Ruim/in & N1 & & -62 \\
\hline & & & & & & Posição d & Mediana & & ${ }^{*} \mathrm{~N} 4 *$ & 100 \\
\hline
\end{tabular}

\begin{tabular}{|c|c|c|c|c|c|c|c|c|c|c|}
\hline \multirow{2}{*}{$\begin{array}{c}\text { Obj. Estudo } \\
\underline{0} \\
\end{array}$} & \multicolumn{5}{|c|}{ 3.1.1 Facilidade de Gerar Pedido do Serviço } & \multirow{2}{*}{$\begin{array}{c}\text { Opções } \\
\text { Mediana } \\
\end{array}$} & \multirow{2}{*}{$\begin{array}{l}\text { Opções } \\
\text { Modelo }\end{array}$} & \multirow{2}{*}{$\begin{array}{r}\text { Nível } \\
\text { Impact }\end{array}$} & \multirow{2}{*}{$\begin{array}{l}\text { Marque } \\
\text { Com->X }\end{array}$} & \multirow[t]{2}{*}{ Escala } \\
\hline & Excel & M Bom & Bom & Indifere & Ruim/in & & & & & \\
\hline Excel & Nulo & M oderado & Forte & M for/Fort & M uitoForte & Ótimo & Excel & N5 & $x$ & 139 \\
\hline M B om & & Nulo & Mo oderado & Fort/M ode & Forte & $\mathrm{BOM}$ & MBom & $* N 4 *$ & & 100 \\
\hline Bom & Esfor & ç०S & Nulo & Mo derado & Fort/M ode & Regular & Bom & N3 & & 50 \\
\hline Indifere & Atrib & uíd os & & Nulo & M ode/Frac & NEUTRO & Indifere & *N2* & & 0 \\
\hline Ruim/in & & & & & Nulo & Negativo & Ruim/in & N1 & & -31 \\
\hline & & & & & & \multicolumn{3}{|c|}{ Posição da Mediana: } & N5 & 139 \\
\hline
\end{tabular}




\begin{tabular}{|c|c|c|c|c|c|c|c|c|c|c|}
\hline \multirow{2}{*}{$\begin{array}{c}\text { Obj. Estudo } \\
\underline{0} \\
\end{array}$} & \multicolumn{5}{|c|}{ 3.1.2 Abrangência de atendimento - Área } & \multirow{2}{*}{\begin{tabular}{|c|} 
Opções \\
Mediana \\
\end{tabular}} & \multirow{2}{*}{$\begin{array}{l}\text { Opções } \\
\text { Modelo }\end{array}$} & \multirow{2}{*}{$\begin{array}{r}\text { Nível } \\
\text { Impact }\end{array}$} & \multirow{2}{*}{$\begin{array}{l}\text { Marque } \\
\text { Com->x }\end{array}$} & \multirow[t]{2}{*}{ Escala } \\
\hline & Excel & M Bom & Bom & Indifere & Ruim/in & & & & & \\
\hline Excel & Nulo & M for/Fort & M uitoForte & Extr/M fort & Extremo & Ótimo & Excel & N5 & & 183 \\
\hline M Bom & & Nulo & M for/Fort & M uitoForte & Extr/M fort & BOM & MBom & *N4* & $x$ & 100 \\
\hline Bom & Esfor & ç०S & Nulo & F rac/M frac & Fraca & Regular & Bom & N3 & & 32 \\
\hline Indifere & Atrib & u íd os & & Nulo & Frac/M frac & NEUTRO & Indifere & *N2* & & 0 \\
\hline Ruim/in & & & & & Nulo & Negativo & Ruim/in & N1 & & -77 \\
\hline & & & & & & Posição da & Mediana & & ${ }^{*} \mathrm{~N} 4 *$ & 100 \\
\hline
\end{tabular}

\begin{tabular}{|c|c|c|c|c|c|c|c|c|c|c|}
\hline \multirow{2}{*}{$\begin{array}{c}\text { Obj. Estudo } \\
\underline{0}\end{array}$} & \multicolumn{5}{|c|}{ 3.1.3 Adaptaccão à Necessidades Especiais } & \multirow{2}{*}{$\begin{array}{c}\text { Opções } \\
\text { Mediana } \\
\end{array}$} & \multirow{2}{*}{$\begin{array}{l}\text { Opções } \\
\text { Modelo }\end{array}$} & \multirow{2}{*}{$\begin{array}{r}\text { Nível } \\
\text { Impact }\end{array}$} & \multirow{2}{*}{$\begin{array}{l}\text { Marque } \\
\text { Com->X }\end{array}$} & \multirow[t]{2}{*}{ Escala } \\
\hline & Excel & M Bom & Bom & Indifere & Ruim/in & & & & & \\
\hline Excel & Nulo & M for/Fort & M uitoForte & Extr/M fort & Extremo & Ótimo & Excel & N5 & & 164 \\
\hline M Bom & & Nulo & Forte & M for/Fort & M uito Forte & BOM & MBom & $* N 4 *$ & & 100 \\
\hline Bom & Esfor & ços & Nulo & Fort/M o de & Forte & Regular & Bom & N3 & & 47 \\
\hline Indifere & Atrib & uídos & & Nulo & Moderado & NEUTRO & Indifere & $* N 2 *$ & $x$ & 0 \\
\hline Ruim/in & & & & & Nulo & Negativo & Ruim/in & N1 & & -50 \\
\hline & & & & & & Posição da & Mediana & & *N2* & 0 \\
\hline
\end{tabular}

\begin{tabular}{|c|c|c|c|c|c|c|c|c|c|c|}
\hline \multirow{2}{*}{$\begin{array}{c}\text { Obj. Estudo } \\
\underline{0}\end{array}$} & \multicolumn{5}{|c|}{ 3.2.1 Tempo de Chegada Após o Pedido } & \multirow{2}{*}{$\begin{array}{c}\text { Opções } \\
\text { Mediana } \\
\end{array}$} & \multirow{2}{*}{$\begin{array}{l}\text { Opções } \\
\text { Modelo }\end{array}$} & \multirow{2}{*}{$\begin{array}{r}\text { Nível } \\
\text { Impact }\end{array}$} & \multirow{2}{*}{$\begin{array}{l}\text { Marque } \\
\text { Com->x }\end{array}$} & \multirow[t]{2}{*}{ Escala } \\
\hline & Excel & M Bom & Bom & Indifere & Ruim/in & & & & & \\
\hline Excel & Nulo & M for/Fort & M uitoForte & Extr/M fort & Extremo & Ótimo & Excel & N5 & & 178 \\
\hline M Bom & & Nulo & M for/Fort & M uitoForte & Extr/M fort & $\mathrm{BOM}$ & MBom & $* N 4 *$ & $x$ & 100 \\
\hline Bom & Es f or & ços & Nulo & Fraca & Mode/Frac & Regular & Bom & N3 & & 35 \\
\hline Indifere & Atrib & uídos & & Nulo & Frac/M frac & NEUTRO & Indifere & $* \mathrm{~N} 2 *$ & & 0 \\
\hline Ruim/in & & & & & Nulo & Negativo & Ruim/in & N1 & & -71 \\
\hline & & & & & & Posição d & Mediana & & *N4* & 100 \\
\hline
\end{tabular}

\begin{tabular}{|c|c|c|c|c|c|c|c|c|c|c|}
\hline \multirow{2}{*}{$\begin{array}{c}\text { Obj. Estudo } \\
\underline{0}\end{array}$} & \multicolumn{5}{|c|}{ 3.2.2 Monitoramento da chegada } & \multirow{2}{*}{$\begin{array}{c}\text { Opções } \\
\text { Mediana }\end{array}$} & \multirow{2}{*}{$\begin{array}{c}\text { Opções } \\
\text { Modelo }\end{array}$} & \multirow{2}{*}{$\begin{array}{r}\text { Nível } \\
\text { Impact }\end{array}$} & \multirow{2}{*}{$\begin{array}{l}\text { Marque } \\
\text { Com->x }\end{array}$} & \multirow[t]{2}{*}{ Escala } \\
\hline & Excel & M Bom & Bom & Indifere & Ruim/in & & & & & \\
\hline Excel & Nulo & Mo derado & Fort/M ode & Forte & M for/Fort & Ótimo & Excel & N5 & $x$ & 128 \\
\hline M Bom & & Nulo & Fort/M ode & Forte & M for/Fort & BOM & MBom & $* N 4 *$ & & 100 \\
\hline Bom & E s f or & Ç O S & Nulo & Moderado & Fort/M ode & Regular & Bom & N3 & & 48 \\
\hline Indifere & Atrib & uídos & & Nulo & Fraca & NEUTRO & Indifere & $* N 2 *$ & & 0 \\
\hline Ruim/in & & & & & Nulo & Negativo & Ruim/in & N1 & & -31 \\
\hline & & & & & & Posição d & Mediana: & & N5 & 128 \\
\hline
\end{tabular}

\begin{tabular}{|c|c|c|c|c|c|c|c|c|c|c|}
\hline \multirow{2}{*}{$\begin{array}{c}\text { Obj. Estudo } \\
\underline{0}\end{array}$} & \multicolumn{5}{|c|}{$\underline{3.2 .3 \text { Horário de funcionamento }}$} & \multirow{2}{*}{$\begin{array}{c}\text { Opções } \\
\text { Mediana }\end{array}$} & \multirow{2}{*}{$\begin{array}{c}\text { Opções } \\
\text { Modelo } \\
\end{array}$} & \multirow{2}{*}{$\begin{array}{r}\text { Nível } \\
\text { Impact }\end{array}$} & \multirow{2}{*}{$\begin{array}{l}\text { Marque } \\
\text { Com->x }\end{array}$} & \multirow[t]{2}{*}{ Escala } \\
\hline & Excel & M Bom & Bom & Indifere & Ruim/in & & & & & \\
\hline Excel & Nulo & Forte & M for/Fort & M uito Forte & Extr/M fort & Ótimo & Excel & N5 & $x$ & 158 \\
\hline M Bom & & Nulo & Fort/M ode & Forte & M for/Fort & BOM & MBom & $* N 4 *$ & & 100 \\
\hline Bom & Esfor & ç OS & Nulo & Mode/Frac & Moderado & Regular & Bom & N3 & & 41 \\
\hline Indifere & Atrib & uídos & & Nulo & Mode/F rac & NEUTRO & Indifere & *N2* & & 0 \\
\hline Ruim/in & & & & & Nulo & Negativo & Ruim/in & N1 & & -46 \\
\hline & & & & & & Posição d & Mediana: & & N5 & 158 \\
\hline
\end{tabular}




\begin{tabular}{|c|c|c|c|c|c|c|c|c|c|c|}
\hline \multirow{2}{*}{$\begin{array}{c}\text { Obj. Estudo } \\
\underline{0}\end{array}$} & \multicolumn{5}{|c|}{ 4.1.1 Sensação de Segurança-Identif. do Serviço } & \multirow{2}{*}{$\begin{array}{l}\text { Opções } \\
\text { Mediana }\end{array}$} & \multirow{2}{*}{$\begin{array}{l}\text { Opções } \\
\text { Modelo }\end{array}$} & \multirow{2}{*}{$\begin{array}{c}\text { Nível } \\
\text { Impact }\end{array}$} & \multirow{2}{*}{$\begin{array}{l}\text { Marque } \\
\text { Com->x }\end{array}$} & \multirow[t]{2}{*}{ Escala } \\
\hline & Excel & M Bom & Bom & Indifere & Ruim/in & & & & & \\
\hline Excel & Nulo & M for/Fort & M uitoForte & Extr/M fort & Extremo & Ótimo & Excel & N5 & $x$ & 173 \\
\hline M B om & & Nulo & Forte & M for/Fort & M uito Forte & $\mathrm{BOM}$ & MBom & *N4* & & 100 \\
\hline Bom & Es f or & ç OS & Nulo & Mode/Frac & Fort/M ode & Regular & Bom & N3 & & 41 \\
\hline Indifere & Atrib & uídos & & Nulo & Fraca & NEUTRO & Indifere & $* N 2 *$ & & 0 \\
\hline Ruim/in & & & & & Nulo & Negativo & Ruim/in & N1 & & -57 \\
\hline & & & & & & Posição da & Mediana & & N5 & 173 \\
\hline
\end{tabular}

\begin{tabular}{|c|c|c|c|c|c|c|c|c|c|c|}
\hline \multirow{2}{*}{$\begin{array}{c}\text { Obj. Estudo } \\
\underline{0}\end{array}$} & \multicolumn{5}{|c|}{ 4.1.2 Itens de segurança do veículo } & \multirow{2}{*}{$\begin{array}{l}\text { Opções } \\
\text { Mediana }\end{array}$} & \multirow{2}{*}{$\begin{array}{l}\text { Opções } \\
\text { Modelo }\end{array}$} & \multirow{2}{*}{$\begin{array}{r}\text { Nível } \\
\text { Impact }\end{array}$} & \multirow{2}{*}{$\begin{array}{l}\text { Marque } \\
\text { Com->x }\end{array}$} & \multirow[t]{2}{*}{ Escala } \\
\hline & Excel & M Bom & Bom & Indifere & Ruim/in & & & & & \\
\hline Excel & Nulo & Mode/Frac & M oderado & Fort/Mode & M for/Fort & Ótimo & Excel & N5 & $x$ & 127 \\
\hline M Bom & & Nulo & Mode/Frac & M o derado & Fort/M ode & $\mathrm{BOM}$ & MBom & *N4* & & 100 \\
\hline Bom & Esfor & $c ̧ \circ \mathrm{s}$ & Nulo & Mode/Frac & Moderado & Regular & Bom & N3 & & 51 \\
\hline Indifere & Atrib & uídos & & Nulo & Fraca & NEUTRO & Indifere & ${ }^{*} \mathrm{~N} 2 *$ & & 0 \\
\hline Ruim/in & & & & & Nulo & Negativo & Ruim/in & N1 & & -21 \\
\hline & & & & & & Posição da & Mediana & & N5 & 127 \\
\hline
\end{tabular}

\begin{tabular}{|c|c|c|c|c|c|c|c|c|c|c|}
\hline \multirow{2}{*}{$\begin{array}{c}\text { Obj. Estudo } \\
\underline{0}\end{array}$} & \multicolumn{5}{|c|}{ 4.1.3 Privacidade } & \multirow{2}{*}{$\begin{array}{l}\text { Opções } \\
\text { Mediana }\end{array}$} & \multirow{2}{*}{$\begin{array}{l}\text { Opções } \\
\text { Modelo }\end{array}$} & \multirow{2}{*}{$\begin{array}{c}\text { Nível } \\
\text { Impact }\end{array}$} & \multirow{2}{*}{$\begin{array}{l}\text { Marque } \\
\text { Com->x }\end{array}$} & \multirow[t]{2}{*}{ Escala } \\
\hline & Excel & M Bom & Bom & Indifere & Ruim/in & & & & & \\
\hline Excel & Nulo & Forte & M for/Fort & M uitoForte & Extr/M fort & Ótimo & Excel & N5 & $x$ & 149 \\
\hline M Bom & & Nulo & Forte & M for/Fort & Extr/M fort & BOM & MBom & *N4* & & 100 \\
\hline Bom & Esfor & ç O S & Nulo & M for/Fort & M uito Forte & Regular & Bom & N3 & & 54 \\
\hline Indifere & Atrib & uíd os & & Nulo & Forte & NEUTRO & Indifere & *N2* & & 0 \\
\hline Ruim/in & & & & & Nulo & Negativo & Ruim/in & N1 & & -40 \\
\hline & & & & & & Posição da & Mediana & & N5 & 149 \\
\hline
\end{tabular}

\begin{tabular}{|c|c|c|c|c|c|c|c|c|c|c|}
\hline \multirow{2}{*}{$\begin{array}{c}\text { Obj. Estudo } \\
\underline{0}\end{array}$} & \multicolumn{5}{|c|}{ 4.1.4 Confiabilidade - Disponiblidade do serviço } & \multirow{2}{*}{$\begin{array}{c}\text { Opções } \\
\text { Mediana }\end{array}$} & \multirow{2}{*}{$\begin{array}{l}\text { Opções } \\
\text { Modelo }\end{array}$} & \multirow{2}{*}{$\begin{array}{r}\text { Nível } \\
\text { Impact }\end{array}$} & \multirow{2}{*}{$\begin{array}{l}\text { Marque } \\
\text { Com->x }\end{array}$} & \multirow[t]{2}{*}{ Escala } \\
\hline & Excel & M Bom & Bom & Indifere & Ruim/in & & & & & \\
\hline Excel & Nulo & M for/Fort & M uito Forte & Extr/M fort & Extremo & Ótimo & Excel & N5 & $x$ & 190 \\
\hline M Bom & & Nulo & M for/Fort & M uito Forte & Extr/M fort & $\mathrm{BOM}$ & MBom & $* N 4^{*}$ & & 100 \\
\hline Bom & Es f or & ç०S & Nulo & M uito Fraca & Frac/M frac & Regular & Bom & N3 & & 30 \\
\hline Indifere & Atrib & uídos & & Nulo & M uitoFraca & NEUTRO & Indifere & $* \mathrm{~N} 2 *$ & & $\mathrm{O}$ \\
\hline Ruim/in & & & & & Nulo & Negativo & Ruim/in & N1 & & -83 \\
\hline & & & & & & Posição d & Mediana & & N5 & 190 \\
\hline
\end{tabular}

\begin{tabular}{|c|c|c|c|c|c|c|c|c|c|c|}
\hline \multirow{2}{*}{$\begin{array}{c}\text { Obj. Estudo } \\
\underline{0}\end{array}$} & \multicolumn{5}{|c|}{ 4.2.1 Serviço de Pós-venda - Atendimento } & \multirow{2}{*}{$\begin{array}{c}\text { Opções } \\
\text { Mediana }\end{array}$} & \multirow{2}{*}{$\begin{array}{l}\text { Opções } \\
\text { Modelo }\end{array}$} & \multirow{2}{*}{$\begin{array}{c}\text { Nível } \\
\text { Impact }\end{array}$} & \multirow{2}{*}{$\begin{array}{l}\text { Marque } \\
\text { Com->x }\end{array}$} & \multirow[t]{2}{*}{ Escala } \\
\hline & Excel & M Bom & Bom & Indifere & Ruim/in & & & & & \\
\hline Excel & Nulo & Fort/Mode & M for/Fort & M uitoForte & Extr/M fort & Ótimo & Excel & N5 & & 153 \\
\hline M Bom & & Nulo & Fort/M ode & Forte & M for/Fort & BOM & MBom & *N4* & $x$ & 100 \\
\hline Bom & E s f o r & ç O S & Nulo & M ode/Frac & M o derado & Regular & Bom & N3 & & 40 \\
\hline Indifere & Atrib & uídos & & Nulo & M ode/Frac & NEUTRO & Indifere & $* \mathrm{~N} 2 *$ & & 0 \\
\hline Ruim/in & & & & & Nulo & Negativo & Ruim/in & N1 & & -47 \\
\hline & & & & & & \multicolumn{3}{|c|}{ Posição da Mediana: } & *N4* & 100 \\
\hline
\end{tabular}




\begin{tabular}{|c|c|c|c|c|c|c|c|c|c|c|}
\hline \multirow{2}{*}{$\begin{array}{c}\text { Obj. Estudo } \\
\underline{0} \\
\end{array}$} & \multicolumn{5}{|c|}{ 4.2.2 Atendimento para reclamações } & \multirow{2}{*}{$\begin{array}{c}\text { Opções } \\
\text { Mediana } \\
\end{array}$} & \multirow{2}{*}{$\begin{array}{l}\text { Opções } \\
\text { Modelo }\end{array}$} & \multirow{2}{*}{$\begin{array}{r}\text { Nível } \\
\text { Impact }\end{array}$} & \multirow{2}{*}{$\begin{array}{l}\text { Marque } \\
\text { Com->x }\end{array}$} & \multirow[t]{2}{*}{ Escala } \\
\hline & Excel & M Bom & Bom & Indifere & Ruim/in & & & & & \\
\hline Excel & Nulo & M for/Fort & M uito Forte & Extr/M fort & Extremo & Ótimo & Excel & N5 & & 179 \\
\hline M Bom & & Nulo & Forte & M uitoForte & Extr/M fort & $\mathrm{BOM}$ & MBom & $* N 4 *$ & $x$ & 100 \\
\hline Bom & Es for & ç O S & Nulo & Fraca & Mode/Frac & Regular & Bom & N3 & & 37 \\
\hline Indifere & Atrib & uídos & & Nulo & Frac/M frac & NEUTRO & Indifere & *N2* & & 0 \\
\hline Ruim/in & & & & & Nulo & Negativo & Ruim/in & N1 & & -67 \\
\hline & & & & & & \multicolumn{3}{|c|}{ Posição da Mediana: } & $* N 4 *$ & 100 \\
\hline
\end{tabular}

